UNIVERSIDADE DE SÃO PAULO

FACULDADE DE FILOSOFIA, LETRAS E CIÊNCIAS HUMANAS

DEPARTAMENTO DE LETRAS CLÁSSICAS E VERNÁCULAS

PROGRAMA DE PÓS-GRADUAÇÃO EM LITERATURA BRASILEIRA

Coisicas diminutas:

figurações da existência infantil em João Guimarães Rosa

FERNANDA YAZBEK RIVITTI

Versão Corrigida

São Paulo

2020 


\section{Coisicas diminutas:}

\section{figurações da existência infantil em João Guimarães Rosa}

Tese apresentada ao Departamento de Literatura Brasileira da Faculdade de Filosofia, Letras e Ciências Humanas da Universidade de São Paulo para obtenção do título de Mestre em Letras Literatura Brasileira.

Orientadora:

Profa. Dra. Yudith Rosenbaum

Versão Corrigida

São Paulo

2020 
Autorizo a reprodução e divulgação total ou parcial deste trabalho, por qualquer meio convencional ou eletrônico, para fins de estudo e pesquisa, desde que citada a fonte.

Catalogação na Publicação Serviço de Biblioteca e Documentação Faculdade de Filosofia, Letras e Ciências Humanas da Universidade de São Paulo

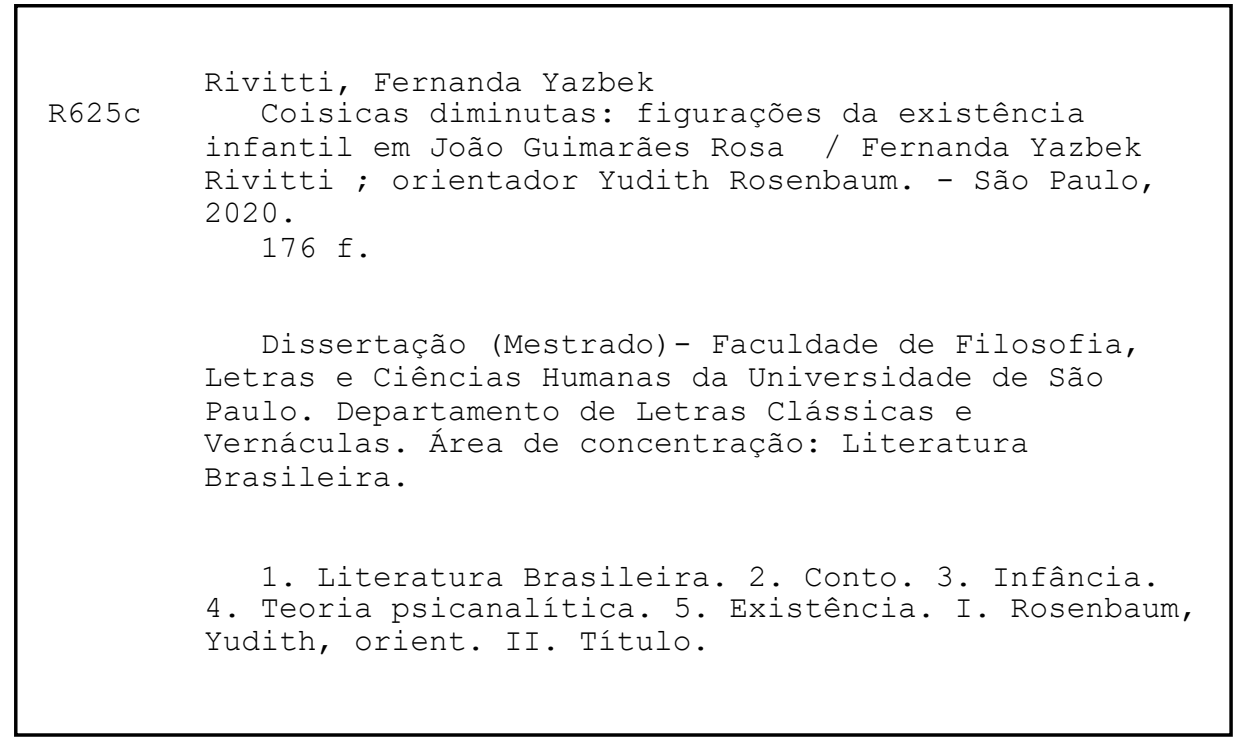




\section{ENTREGA DO EXEMPLAR CORRIGIDO DA DISSERTACૃ̃̃O/TESE}

Termo de Ciência e Concordância do (a) orientador (a)

Nome do (a) aluno (a): Fernanda Yazbek Rivitti

Data da defesa: $08 / 12 / 2020$

Nome do Prof. (a) orientador (a): Yudith Rosenbaum

Nos termos da legislação vigente, declaro ESTAR CIENTE do conteúdo deste

EXEMPLAR CORRIGIDO elaborado em atenção às sugestões dos membros da comissão Julgadora na sessão de defesa do trabalho, manifestando-me plenamente favorável ao seu encaminhamento e publicação no Portal Digital de Teses da USP.

São Paulo, 29/01/2021

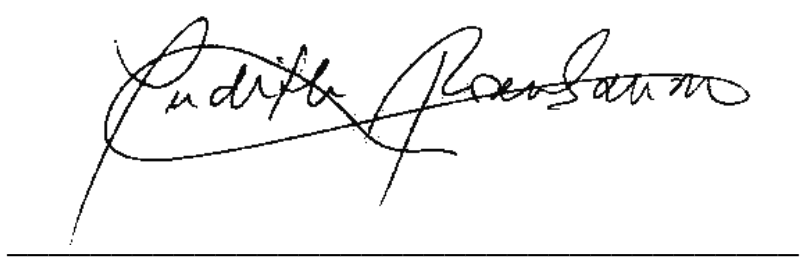

(Assinatura do (a) orientador (a) 


\section{Folha de Aprovação}

RIVITTI, Fernanda Yazbek. Coisicas diminutas: figurações da existência infantil em João Guimarães Rosa. Dissertação apresentada ao programa de Pós-Graduação em Literatura Brasileira da Universidade de São Paulo para obtenção do título de Mestre em Literatura Brasileira.

Aprovada em:

1

Orientadora: Profa. Dra. Yudith Rosenbaum

\section{Banca Examinadora}

Examinador(a): Instituição:

Julgamento:

Assinatura:

Examinador(a): Instituição:

Julgamento:

Assinatura:

Examinador(a): Instituição:

Julgamento:

Assinatura: 


\section{Agradecimentos}

A criação do que quer que seja não tem princípio nem fim. Ela se faz de tudo o que nos atravessou desde o primeiro abrir de olhos - alguns dirão, até antes disso. Como saber se na composição deste trabalho não influiu o olhar sonhador, amoroso ou desiludido que algum dia surpreendi em qualquer parente, o tom de voz daqueles que me contaram histórias, a generosidade fácil de um sertanejo desconhecido pelas estradas de Minas, ou o cheiro amanhecente do pomar em que brinquei parte de minha infância? Não temos essa clareza, e o que nos compôs pesquisadores, amantes da arte, da literatura e, no meu caso, do universo rosiano, se perde nas dobras do sentido e do vivido.

Resta, portanto, nomear aqueles que o coração guarda mais perto e sabe presentes:

A meus pais, que me geraram no amor e que, aos meus amores, desejos, interesses, deram sempre chão e asas; que vibram junto, celebram, participam de corpo e alma. A eles, inclusive, muitas das referências bibliográficas aqui presentes se devem, por estarem durante alguns meses mais perto de meus livros de consulta do que eu.

Às minhas avós, pela arte ancestral, pelas histórias, pela alegria de partilharem comigo alimentos de corpo e espírito, e pelo brilho sempre presente nos olhos ao me verem... guardiãs de eu menina.

Aos professores todos que passaram por minha vida, desde a tia que cobrava beijos à entrada da sala até os acadêmicos que me abriram seus vastos saberes. A vocês devo o movimento do pensamento, a mágica alquimia entre esforço e entusiasmo mas, antes de tudo, a paixão pela alta tarefa de despertar no outro o desejo por aprender e partilhar, as duas molas que movem o mundo.

Aos amigos que me acompanham desde às fraldas e àqueles que recentemente conheci... vocês são o ouro achado, os parceiros que fazem a caminhada valer a pena. Quantas de nossas conversas, viagens, trocas, trabalhos, danças, risos e lágrimas não estarão tecidos no que sou e faço?

À dança e às estórias, que revolucionaram tudo em minha vida.

A João Guimarães Rosa, maior do que quaisquer palavras que eu possa aqui escrever.

Aos amigos rosianos de tantas partes, mas em especial ao povo do Sertão: Vocês me deram o Rosa que eu ainda não havia encontrado nas páginas dos livros - mas que 
lá estava. E me deram mais... o existir de vocês, feito de pedra e de flor, de pó, de sol e céu ultrapassa todo o entendimento. Ele está, talvez, mais entremeado a essas páginas do que eu mesma saiba.

A todos aqueles que têm caminhado comigo em meus grupos de estudos literários. Pesquisar só tem sentido porque sei que o pensamento se tornará um rio vivo, de muitos afluentes, dentro de cada um de nós.

Aos professores doutores Adélia Bezerra de Meneses e Erich Soares Nogueira pelas leituras tão cuidadosas no exame de qualificação, e às Profas Dras Belinda Mandelbaum e Marise Hansen, que se juntaram a eles na banca da defesa. Estas páginas devem muito à generosidade de suas ideias - empréstimos de livros, inclusive! -, às suas sugestões, abertura de caminhos e questionamentos.

À amiga e parceira Letícia Liesenfeld, cuja leitura do primeiro capítulo contribuiu com importantes referências do universo da literatura infantil.

À Universidade de São Paulo, onde tanto aprendi desde a graduação.

À Capes, pelo auxílio inestimável durante mais de um ano, que me permitiu dedicar tempo e calma a esta pesquisa.

Ao Vale do Matutu, meu lugar de amor na Terra, casa e útero em que gestei muito do que aqui está escrito.

E por fim, àquela que já estou agradecendo desde as primeiras linhas... ela faz parte dos que me semearam e seguem semeando saberes e afetos. Com ela aprendi o olhar para os textos e o olhar para os alunos que me acompanham até hoje. Ela, que põe tudo de si em tudo o que faz, me deu suas horas de conversas para pensar junto, leu, releu, tresleu, abriu portas e janelas para que o texto respirasse e ganhasse sempre mais corpo, mais vozes, mais caminhos... o amou junto comigo.

Yudith Rosenbaum, a você, minha gratidão e admiração, sempre.

E ao que tem muitos nomes e nenhum, mas que é a raiz de tudo, em tudo está, a tudo permeia, fora dele nada existe. A Ele pertence tudo o que sou e faço. 


\section{Resumo}

Este é um estudo sobre as figurações literárias dos infantes na obra de João Guimarães Rosa. Partindo do pressuposto de que estas personagens apresentam uma forma outra de ser que se articula, em mais de um aspecto, ao universo rosiano e à própria poética do autor, elegeram-se como eixo analítico quatro protagonistas de cinco contos rosianos: Dja/Iaí, de "Tresaventura"; Nhinhinha, de "A Menina de Lá"; Brejeirinha, de "Partida do Audaz Navegante" e o Menino, de "As margens da alegria" e "Os cimos". O estudo parte da contextualização histórica de sentimento da infância, segundo Philippe Ariès, para sondar perspectivas de carência e potência na figuração literária dos infantes, e convoca conceitos da psicanálise e filosofia a respeito da forma de existência infantil para dar lastro a sua representação pela literatura rosiana. De um olhar vertical para os contos e seus protagonistas e um olhar transversal que os atravessa comparativamente, emergiram os temas e imagens que compõem essa forma de existência bem como suas afinidades e ressonâncias com alguns dos grandes temas rosianos: a coincidência dos opostos e o princípio da reversibilidade/mobilidade, que desafiam a lógica linear e o pensamento cartesiano; a relação com a linguagem enquanto elemento móvel, plástico, metafísico porque genesíaco em sua capacidade de reinaugurar o mundo; a face lúdica e criativa da existência, a Graça em suas muitas acepções. Falta e potência tensionam o campo da infância e também constituem a vivência infante em sua articulação com as condições do sertão rosiano, sendo mais uma face do tema proposto. Explora-se a proximidade dos infantes à Origem, conceito delineado a partir de perspectivas sociológicas, psicanalíticas e antropológicas, que os torna "originários" e "originais", imprimindo-lhes uma anterioridade de ser que se faz plena em si mesma e configura sua relação com o mundo e a linguagem na contramão do pensamento hegemônico, em lógica aparentemente "desarrazoada", antes participativa do que analítica, elucidando também seu parentesco com os primitivos, caboclos e sertanejos. No último capítulo, são convocados personagens adultos que comungam de aspectos dessa existência infante, corroborando a ideia de que ela, mesmo radicada na fase inicial da biografia humana, permeia nosso vir a ser.

Palavras-chave: João Guimarães Rosa. Infância. Existência. Psicanálise. Literatura Brasileira. 


\begin{abstract}
This is a study about the literary depiction of children in João Guimarães Rosa's works. Supposing these characters present a particular state of being which articulates itself in more than one aspect to Rosa's universe and poetic conceptions, we have singled out four main characters from five short stories in which to focus our analysis: Dja/Iaí, of "Tresaventura"; Nhinhinha, of "A Menina de Lá"; Brejeirinha, of "Partida do Audaz Navegante" and the Boy, of "As margens da alegria" and "Os cimos". From a brief historical contextualization of the sentiment of childhood according to Philippe Ariés, we explore the perspective of deficiency and potency in the infants' literary depiction, and summon psychoanalytical and philosophical concepts about children's' ways and behavior that are found in their depiction by Guimarães Rosa. From a vertical study of these short stories and their main characters and a transversal glance that compares them emerged the themes and images that come together to compose this form of existence, as well as their affinities with some of the main themes in Rosa's literature: the coincidence of opposites, the principle of reversibility and mobility which defy linear and Cartesian logic; the concept of language as a plastic, fluid element, metaphysical because capable of reinventing the world, making it born anew; the playful, creative aspects of life; "grace" in it multiple meanings. Lack and potency impart tension to the realm of infancy and also determine the infant's existence in relation to Rosa's conception of sertão. We explore the infants' proximity to the Origin, a concept defined from sociological, psychoanalytical and anthropological perspectives, which makes them "originary" and "original", conforms a state "prior" to existence which nonetheless is sufficient and potent in itself, and makes their rapport to world and language contrary to hegemonic structure of thought, bearers of an apparently irrational logic, more participatory than analytical, which sheds light on their kinship to the primitive man, the "sertanejos", country people. The last chapter analyzes adult characters in whom this infant's existence traces appear, making it possible to affirm that, although its roots are to be found in the initial stages of life, it emerges also as a state of existence we are to attain.
\end{abstract}

Key-words: João Guimarães Rosa. Infancy. Existence. Psychoanalysis. Brazilian Literature. 



\section{Sumário}

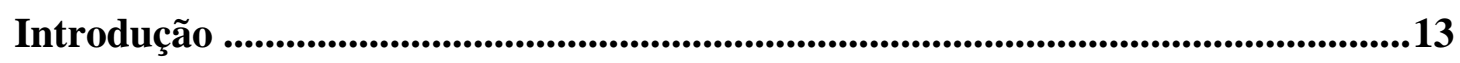

Pé por pé, pé por si: palmilhando essas poucas veredas, veredazinhas.................... 13

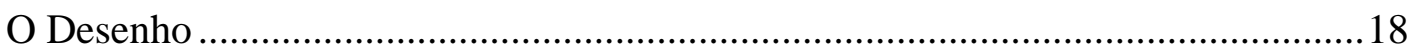

Capítulo 1. No encalço de coisicas diminutas ............................................................22

1.1 Carência ou potência: olhares para a infância .................................................22

1.2 Psicanálise e filosofia: pistas sobre o existir infantil.....................................28

1.3 O Olhar de Rosa: "Infância é coisa, coisa?" ....................................................... 32

1.3.1 “No princípio era...”: relações com a Origem no existir infantil ............................. 37

1.3.2 0 móvel mundo: existência e linguagem....................................................................... 43

Capítulo 2. Tres-aventura ...................................................................................................52

$2.1 \mathrm{O}$ absurdo e a graça: de massas, letras e fios ..................................................52

2.2 De sonho e de pó: no miolo da luz, no marrom da terra ..................................56

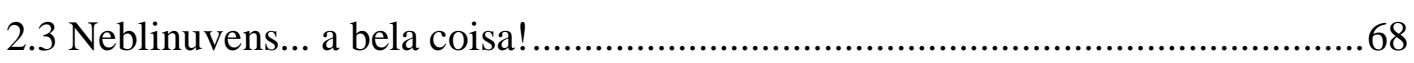

2.4 Hermenêutica e Aletria... fios sem arremate .................................................... 73

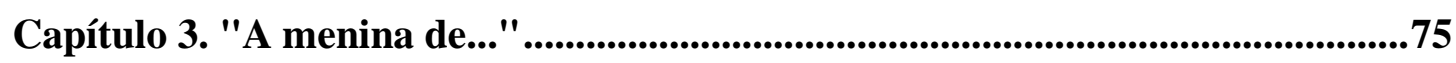

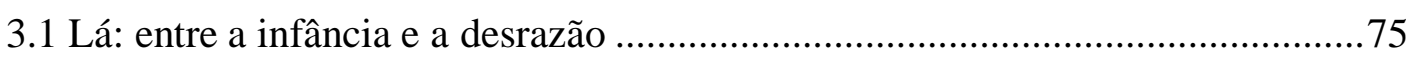

3.2 Fazendo vácuos... a estranha graça................................................................ 79

3.3 "Senhora Vizinha": no limiar da terceira margem .......................................... 85

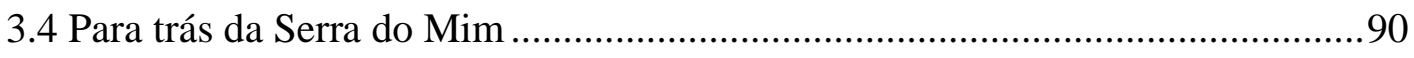

Capítulo 4. O "Aldaz" Navegante ................................................................................95

4.1 Brincando a realidade: o escritor e a criança.................................................95

4.2 Navegar é preciso. Narrar também..............................................................99

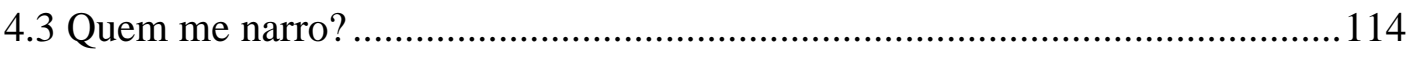

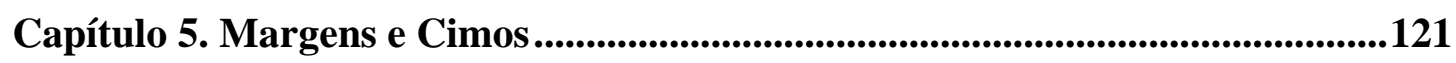

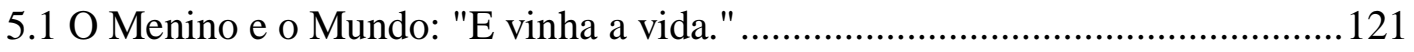

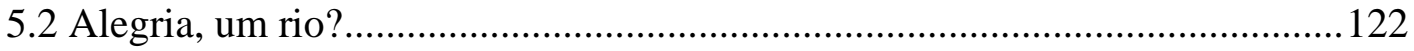

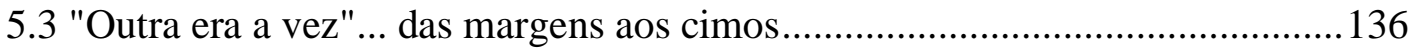

$5.4 \mathrm{O}$ trabalho do pássaro: tempo, tempo, tempo, tempo....................................... 142

5.5 Para fora das molduras: os cimos da existência ............................................... 145

Capítulo 6. Origem, Fim: "... até se virar menino" ...................................................149

6.1 Fios que se cruzam... com outros infantes.................................................... 149

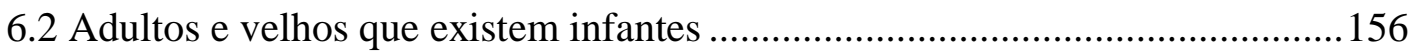

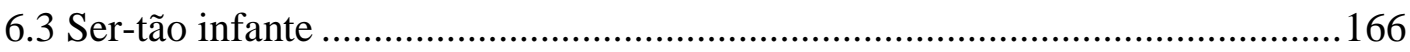


À guisa de conclusão - De Sorrisos e Enigmas .........................................................170

Referências bibliográficas .............................................................................................173

Obras de João Guimarães Rosa …………………………………………….......173

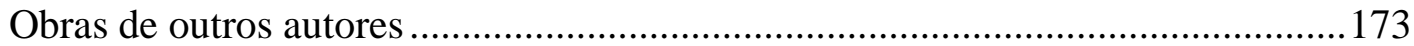




\section{Introdução}

\section{Pé por pé, pé por si: palmilhando essas poucas veredas, veredazinhas ${ }^{1}$}

O homem seria metafisicamente grande se a criança fosse seu mestre SÖREN KIERKEGAARD

O presente trabalho parte, talvez como tudo a que se dedique tempo e energia, de um misto de indagação e suspeita acerca das figurações da infância na obra de João Guimarães Rosa, autor de vulto, de temas tão vastos em saberes quanto em profundidade filosófica ou metafísica, mas igualmente interessado pelo pequeno e que, suspeitamos, concordaria com a epígrafe acima - o que, já de si, é convite para olharmos este "pequeno" numa chave de grandezas outras. Há, certamente, algo nos pequeninos rosianos que nos diz sobre uma forma outra de ser. Qual o seu fundo, seus traços, rastros, de que chão ou céu ela se faz? Ainda, que lugar ela ocupa dentro do universo literário de Rosa? Parte da crítica já apontou temas ou aspectos formais e semânticos que encontram ressonância nesse caráter infante da existência, porém não são muitos, ainda, os trabalhos que alinhem um olhar geral para o tema à análise das obras em si.

Diante disso, escolhemos sondar as construções de personagens infantis em mais de uma obra do autor para descortinar os temas e imagens que as perpassam e, possivelmente, as irmanam. Traçando um arco por alguns dos contos em que os pequenos se fazem protagonistas, aliamos uma análise vertical de cada obra a uma linha transversal que as atravesse comparativamente para iluminar uma concepção de infância que se articule ao universo rosiano e à própria poética do autor.

Perseguimos aqui o tema do infantil no que ele guarda de afinidades e ressonâncias com alguns dos grandes temas rosianos, que serão desdobrados mais adiante: a coincidência dos opostos e o princípio da reversibilidade/mobilidade, que desafiam a lógica linear e o pensamento cartesiano; a relação com a linguagem enquanto elemento também móvel, plástico, metafísico porque genesíaco em sua capacidade de reinaugurar o mundo; a face lúdica e criativa da existência, que não deixa de aparentar-se a todas essas outras. Perpassa a constituição das crianças rosianas um estado de existência próximo à origem, a uma anterioridade de ser que, não obstante, 
se faz plena em si mesma, em seu "ser aî", cuja relação com o mundo se faz a partir de lógica outra, aparentemente "desarrazoada", antes participativa e mística do que analítica, e é de tal estado que parecem emergir os aspectos apontados, elucidando também o parentesco dessas personagens aos primitivos, caboclos e sertanejos. Vislumbra-se nessa existência um sentimento de integração do sujeito com o mundo, que, em maior ou menor grau, faz da relação entre ambos tão fluida, móvel e inventiva quanto a relação que ele mantém com a linguagem.

Os contos escolhidos para análise figuram, todos, crianças como protagonistas, e do olhar para eles depreenderam-se os temas e questões acima expostos. Não são poucas nem marginais as personagens infantis na literatura rosiana. Paulo Rónai, escrevendo sobre Primeiras Estórias, ressaltou que a maioria das personagens se enquadra na categoria dos loucos ou das crianças (2001, p. 23). De fato, temos o Menino, protagonista dos contos que abrem e encerram o livro, "As margens da alegria" e "Os Cimos", respectivamente; Nhinhinha, em "A menina de lá"; Brejeirinha em "Partida do Audaz Navegante"; o narrador e seus amigos em "Pirlimpsiquice" (ainda que, aqui, tenhamos a memória de um adulto narrando sua infância e não a criança "em ato" diante de nós - como é também o caso, em processo mnemônico ainda mais radical, do narrador de "Nenhum, Nenhuma"). Não como protagonista, mas como imagem-chave essencial para a construção de sentido do conto, a infância aparece quase como resposta-desfecho da insólita e metafísica experiência d"'O espelho" - ainda que mais reponha do que elucide o mistério.

Como em Rosa, invariavelmente, a linearidade se subverte, antes das Primeiras Estórias existiram Corpo de Baile e Grande Sertão: Veredas. Neste, O Menino (novamente! Mas que desta feita ganha nome(s) no desenrolar da narrativa), estudado por Benedito Nunes (2013, p. 37-77) em sua condição andrógina, ambígua, própria da infância mas também de uma instância divina e arcaica, ocupa o centro de praticamente todo o relato de Riobaldo e, portanto, de sua vida. Lá está também o menino Guirigó, à primeira vista marginal na trama, mas que figura igualmente uma ambiguidade, misto de dimensão inocente e diabólica, e que está ao lado do protagonista no momento decisivo da batalha final. A novela "Campo Geral" abre a obra Corpo de Baile com o protagonista Miguilim - estória que o próprio Rosa declarou ser a de que mais gostava entre seus escritos - justificando a escolha por ser ela "mais forte que o autor, sempre 
me emociona"1 (ROSA, apud GUIMARÃES, V. 2006, p. 168). Ao lado de Miguilim temos o irmãozinho Dito, com perspicácia fora do comum, com suas formulações filosóficas e seu jeito de apreender súbito as complexas dinâmicas do mundo adulto cujo sentido invariavelmente escapa a Miguilim. Além dos demais irmãos e irmãs, merece destaque o menino Grivo, por sua relação com as palavras ${ }^{2}$ graças à qual se deve seu papel central em "Cara-de-Bronze", quando o reencontramos já adulto, em busca do "quem das coisas", o invisível-indizível que se esconde por detrás do acostumado olhar... a própria poesia do mundo. Ainda em Corpo de Baile, os únicos recadeiros que não figuram na galeria dos loucos no magistral "Recado do Morro" são o violeiro Laudelim - o artista - e o menino Joãozezim - a criança.

Sagarana, que veio antes de todos, tem ao menos duas crianças dignas de nota: o carreiro Tiãozinho, em "Conversa de bois", e o menino pretinho, protagonista de relato assombroso de um dos vaqueiros em "O burrinho pedrês". Tutaméia, as Terceiras Estórias após as Primeiras, conta aparentemente com apenas uma protagonista mirim - Maria Euzinha, tratada por Djá ou Iaí, no conto "Tresaventura". Assim como ocorre em "O espelho", entretanto, há um conto cujo sentido converge poderosamente para a imagem da infância, no caso em seu arquétipo místico, que une princípio e fim na imagem de morte-renascimento que reinaugura o mundo: "Presepe", conto cujo protagonista-ancião inesperadamente reverte-se ante nossos olhos em Jesus Menino. Ave, palavra, póstumo, nos deu ainda "Fita verde no cabelo", nova-velha estória em que uma "meninazinha" faz sua saída da dimensão de inocência infantil ao encontrarse com o "lobo" da morte.

Não é intuito deste percurso - nem seu escopo permite - abarcar todas as figurações infantis da obra de Rosa. Priorizamos para constituir eixo central de cada capítulo quatro protagonistas que figuram em cinco contos, a saber: Dja/Iaí, de "Tresaventura"; Nhinhinha, de "A Menina de Lá"; Brejeirinha, de "Partida do Audaz Navegante" e o Menino, de "As margens da alegria" e "Os cimos" ${ }^{3}$. Enquanto os dois últimos mereceram já razoável atenção da crítica, em mais de um viés analítico ${ }^{4}$, o

\footnotetext{
${ }^{1}$ Carta em resposta a questionário de sua jovem prima Lenice, à época estudante em Curvelo (MG).

2 "[...] a gente ficava logo gostando daquele menino das palavras sozinhas" (ROSA, 2001, p. 100).

${ }^{3} \mathrm{O}$ conto "Tresaventura" encontra-se em Tutaméia, Terceiras; todos os demais integram as Primeiras Estórias.

${ }^{4}$ Destacam-se os trabalhos de Ana Paula Pacheco, no primeiro capítulo de seu Lugar do Mito (2006), o ensaio "O amor em Guimarães Rosa", de Benedito Nunes (2013), "A trajetória do Menino nas estórias de Guimarães Rosa" (1988), de Vania Maria Resende, e o trabalho de Bernardina Maria de Sousa Leal, que em seu Chegar à Infância (2011) aborda também o conto "A menina de lá".
} 
mesmo não se pode dizer dos três primeiros ${ }^{5}$, o que constitui uma das motivações de sua eleição, no desejo de abrir ao leitor veredas pouco exploradas.

Outra motivação, mais premente, contudo, norteou tal seleção. Ela nos fornece um arco que vai da infância mais tenra, nos dois primeiros contos, passando por estágio intermediário no terceiro até o limiar da idade em que as experiências de queda do paraíso se anunciam, nos dois últimos. Essa ordem progressiva nos interessa pois permite melhor entrever que, embora certos temas sejam recorrentes em todos os estágios - relação profunda com a natureza, olhar maravilhado e inaugural para o mundo, capacidade intuitiva, estado existencial fluido e movente que perpassa a relação com a linguagem e propõe a reversibilidade dos polos e a coincidência dos opostos em desafio à lógica cartesiana adulta - os contos iniciais, cujas protagonistas estão mais próximas à Origem $^{6}$, adquirem dimensões claramente mais metafísicas, com crianças quase míticas, tendendo ao simbólico, enquanto aquelas que dela já se distanciaram um pouco adquirem tons mais realistas, imprimindo maiores tensões entre as polaridades constitutivas da existência; são crianças que, sem deixar de sê-lo, terão de equacionar sua qualidade de infante no que ela tem de subversiva, móvel, criativa, intuitiva, com vivências que aparentemente põem em xeque seu sentimento de plenitude na integração com o mundo e os seres, confrontando-as com as dimensões materialista e utilitária do viver.

Cabe apontar que optamos por um estudo temático-estilístico, por meio de visada analítica rente ao texto para que, das imagens e temas desentranhados de cada conto, emergisse a figuração do infante. Assim, em um estudo vertical, o close-reading foi a principal atitude crítica adotada. As análises partiram da organização do discurso linguístico, da articulação da narrativa em seus planos sintáticos, metafóricos, metonímicos, sonoros etc. Em movimento transversal, exploramos as imagens e temas que se fazem comuns aos protagonistas infantis, surpreendendo-os em sua relação com princípios de composição e com temas norteadores da obra rosiana. Para tanto, estudos da crítica literária rosiana, sobretudo de Antonio Candido, Adélia Bezerra de Meneses, Alfredo Bosi, Ana Paula Pacheco, Benedito Nunes, Davi Arrigucci Jr., Erich Soares Nogueira, Luis Costa Lima, Walnice Nogueira Galvão, Yudith Rosenbaum e,

\footnotetext{
${ }^{5}$ Ressalve-se, aqui, o belo ensaio "'Partida do Audaz Navegante', de Guimarães Rosa: ressonâncias odisseicas, em clave minimalista", de Adélia Bezerra de Meneses (2015, p. 55-66).

${ }^{6}$ Este conceito e as variadas significações que ele engloba se encontra desenvolvido no Capítulo 1 do presente trabalho.
} 
especificamente os que tocaram em temas do infantil na obra, Henriquieta Lisboa e Vânia Maria Resende, fizeram-se base constante de referência e diálogo. ${ }^{7}$

O último capítulo da tese dedica-se a ampliar a imagem do existir infantil a partir de aproximações entre aspectos dos protagonistas aqui já estudados e outras personagens infantis de Rosa, bem como vislumbrar essa qualidade infante não apenas como prerrogativa das crianças. Adultos como o Grivo, de "Cara-de-Bronze", Dona Rosalina, em "Lélio e Lina" e o já mencionado narrador de "O espelho" participam de alguma maneira dessa forma de existência, ou trazem-nos imagens que a ampliam. Apontamos brevemente os espelhamentos e ressonâncias entre alguns dos aspectos chave que enformam o existir infante e os traços físicos e metafísicos que plasmam o "sertão" rosiano. No percurso com cada conto, a primazia coube ao texto literário, e somente a partir do que dele emergiu como imagem e temática é que saberes de outros domínios - notadamente da filosofia, hermenêutica e psicanálise - foram agenciados.

A visada filosófica encontrou mediação nos trabalhos de Benedito Nunes, cujo incurso pelo arquétipo da Criança Divina, abordado no ensaio "O Amor na obra de Guimarães Rosa", abriu campo para pensar a condição do infante em sua ambiguidade de princípio e fim da existência humana, sua proximidade ao lugar misterioso de onde se vem e para onde se retorna, dentro de um pensamento platônico do qual se encontram lastros no texto rosiano. Na mesma linha estão os estudos de Carl Kerényi, em "The myth of the divine child and the mysteries of Eleusis". Algumas ideias da antropologia, sobretudo os estudos de Lévy-Bruhl e sua concepção da Lei da Participação, que admite o princípio da contradição para explicar o pensamento das sociedades ditas "primitivas", foram convocados em diálogo com esse estar no mundo "originário" e "original" também presente nos infantes. A teoria da reminiscência, que aparece de forma difusa na obra de Platão, principalmente nos diálogos Fedro, Fédon e Mênon, embasa as leituras do infante como aquele que guarda, ainda, reflexo de um saber "mais alto", de ordem não puramente terrena, especialmente nos contos em que temos os pequenos em mais tenra idade - e se mostrou particularmente fértil para iluminar a análise de "Tresaventura".

\footnotetext{
${ }^{7}$ Artigos de alunos e professores publicados em diversos volumes das revistas Scripta e Veredas de Rosa, produzidas a partir de seminários realizados pela Puc-Minas, foram de extrema valia para complementar os estudos da bibliografia rosiana a respeito da infância. Agradeço "coraçãomente" à generosidade da professora Adélia Bezerra de Meneses pelo empréstimo deste material.
} 
Abordagens psicanalíticas tiveram como ponto de partida $O$ brincar $e$ a realidade, de Donald Winnicott, e, de Sigmund Freud, "Escritores criativos e devaneios" e "Além do princípio do prazer", que nortearam o olhar para a criança principalmente em seus processos de brincar, fabular e elaborar experiências. De Freud, ainda, os conceitos de princípio do prazer e princípio da realidade, a partir de "Formulações sobre os dois princípios de funcionamento mental", foram convocados nas experiências de confronto do estado de plenitude infantil com as contingências externas do ambiente.

O mergulho na relação do infante com a linguagem em sua potência genesíaca, de palavra inaugural, adâmica, que faz existir o mundo, encontrou diálogos em estudos de Ernst Cassirer, no capítulo "A palavra mágica" de seu Linguagem e mito, e no artigo "A imagem", de Octavio Paz, aproveitando-se a ideia de "palavra-coisa" como conjugação entre modo poético não utilitário e a transparência representacional do mundo pelo infante. Incursões pelo pensamento clássico descortinam ainda sentidos da palavra arcaica em sua potência demiúrgica, em especial nos estudos de Jaa Torrano acerca do grande poema genesíaco de Hesíodo, A Teogonia. Foram todos estudos que permitiram traçar pontos de contato entre a palavra do infante, a palavra arcaica e a poética.

\section{O Desenho}

Ao adentrar o emaranhado labiríntico de fios de que todo texto se tece, sempre bom contar com mapa ou bússola. Deixamos aqui, portanto, um breve desenho dos capítulos e as questões centrais de que se ocupam.

O primeiro capítulo aborda o tema da infância para perscrutar perspectivas de carência ou potência em sua figuração literária. Parte de exemplos da literatura universal, passando pela contextualização histórica de sentimento da infância, segundo Philippe Ariès, bem como por alguns aportes da psicologia, psicanálise e filosofia para delinear conceitos a respeito da forma de existência infantil que dão lastro a sua representação conforme a encontramos na literatura. Adentra-se, então, a infância na obra rosiana, apontando os aspectos gerais que dela emergiram nas análises dos contos, enfocando a reversibilidade e coincidência de contrários, a analogia entre a forma de pensamento infante e a do primitivo segundo estudos antropológicos de Lévy-Bruhl, as dimensões que formam o que identificamos como participação do infante em um estado 
"originário" e "original" e, por fim, a mobilidade e criatividade como concepção da existência e da linguagem em Rosa e em seus infantes.

O segundo capítulo enfoca a protagonista Djá/Iaí, de "Tresaventura", que no nome traz referência a um aqui/agora absolutos e apresenta-nos uma existência ainda mais ancorada no mundo das ideias do que no da matéria, no princípio do prazer mais do que no da realidade, contrapondo a todo instante a supremacia da beleza, do desejo e da comunhão com a natureza ao senso prático e alertas de hostilidade do mundo vindo dos adultos. Em um espaço que tem "vestígios de pré-idade", o anseio por uma beleza luminosa nunca vista - o arrozal, "sonhado lembrado" pela pequena, em ecos de reminiscência platônica -, moverá sua aventura até o confronto com a realidade e seus perigos que, embora confirme a visão dos mais velhos, será alterada pelo desejo e ação da pequena.

O terceiro capítulo tem, em Nhinhinha, vasto campo de reversibilidade entre carência e plenitude, loucura e santidade, normalidade e anormalidade, silêncio e verbo criador, desdobrando a imagem do infante, em sua anterioridade em relação à fala normativa, à aculturação, ao utilitarismo, em um "lugar de existência" cujas dimensões podem ser psíquicas e/ou metafísicas. Rastreando a experiência da ordem do aberto, do indefinível e inominável que o locativo "lá" configura na narrativa - e que é própria também deste país da infância, avesso à concepção de mundo estanque e materialista do adulto - o conceito de "desrazão", conforme tomado de Foucault e Blanchot por Peter Pál Pelbart, norteia o percurso de análise, enquanto os estudos classicistas de Jaa Torrano, em seu ensaio sobre a Teogonia, iluminam a aproximação da palavra de Nhinhinha à palavra arcaica, poética, fundadora.

O quarto capítulo, centrado em "Partida do Audaz Navegante", parece configurar estágio intermediário, em que vislumbramos, em chave mínima, uma "partida" da criança do seio materno para a aventura da vida. Sua relação com a linguagem não cria, de fato, materialidades, porém, unindo o brincar e o fabular, não deixa de operar a realidade, transformando instâncias subjetivas das personagens ao seu redor, cujo estado psíquico ela havia "pegado no ar", em comunicação tão intuitiva quanto a de Djá/Iaí com o sapo. Com Brejeirinha, porém, percorreremos a coincidência dos opostos e a reversibilidade dos polos mais propriamente no imbricamento do brincar e fabular que misturam realidade objetiva e subjetiva, e nas aproximações entre a criança e o escritor, em verdadeira celebração do ato inventivo que apõe mais de uma moldura narrativa para ultrapassar as fronteiras entre elas, misturando não apenas a 
realidade objetiva das personagens à estória inventada por Brejeirinha, mas a própria personagenzinha fabulista ao narrador do conto; aqui a alegria do jogo com as palavras põe em ato, em múltiplos níveis narrativos, a concepção rosiana da língua enquanto seu elemento metafísico. Contribuíram para este estudo aportes psicanalíticos, em especial o ensaio "Escritores criativos e devaneios", de Freud, e a obra $O$ brincar e a realidade, de Winnicott.

Essas três pequeninas evocam uma existência que põe em xeque, a todo instante, certos ditames da lógica adulta, cartesiana, utilitária, social. O instinto de sobrevivência, noções de maldade ou perigo, e o medo delas decorrente, o reconhecimento de instâncias de poder/autoridade de um sistema hierárquico, possuem nas protagonistas pouca ou nenhuma ressonância. Percebe-se que esses três contos pertencem a uma mesma forma de figuração infantil: aquela que, quando confrontada com o universo adulto e sua realidade empírica, não é desfigurada por ele, antes o abala, abrindo frestas no real/material por onde se vislumbrem possibilidades outras de existência.

Já o Menino de "As margens da alegria" e "Os cimos" pertence a outra estirpe, trabalhada no quinto capítulo. Aqui a supremacia do infante quase demiúrgico, o triunfo de sua criatividade e subversão, cede ao processo de individuação no inescapável trânsito do estado originário da plenitude da infância para a "descoberta do mundo", em sofrida queda do paraíso, quando o exterior não mais ressoa, e sim, destoa de seus impulsos interiores. Não por acaso alguns estudos já se debruçaram sobre este Menino em comparação com o autobiográfico Miguilim, que será também convocado em chave comparativa. São crianças a quem se farão sentir a dor, o medo, a morte, a violência, a maldade, a impotência, o senso de injustiça; menos místicas ou mágicas, elas não deixarão, entretanto, de participar do estado de existência infante e, por meio deste lastro originário, em que esfumaçam-se as fronteiras entre sujeito e mundo, palavra e coisa, luz e sombra, imanência e transcendência, equacionarão as dores e agruras da existência, principalmente pela relação com a natureza e o reino animal. Em "As margens da alegria", a imagem do vaga-lume se faz resgate da beleza e integração da alegria com a tristeza; em "Os Cimos", a imagem do voo matinal do tucano unificado à paisagem, à luz, à saudade da mãe enferma, desemboca em cena quase apoteótica de "acesso repentino à plenitude do mundo" (NUNES, 2013, p. 61), em que todas as experiências ambíguas, das vivências mais concretas às mais abstratas, se unificam num único êxtase, apontando, ainda uma vez, para a permanente reversibilidade e integração que configuram a "coerência do mistério geral" rosiano. 
Vemos que, nesse último estágio, os mesmos temas que ancoram as figurações do infante colocam-se a serviço de um "aprender a viver", de uma operação quiçá ainda mais mágica, posto que, expulsas do paraíso primordial, confrontando-se com a alteridade e assimilando algo da lógica objetiva do universo adulto, resgatam sua criatividade, senso de integração, graça e alegria para atingir forma outra, que não a adulta, de entrar em relação com a realidade imanente.

O sexto e último capítulo deste estudo dedica-se a traçar mais claramente os pontos de contato entre as personagens analisadas, bem como chamar atenção a outras que com elas dialoguem. Nele temos ainda imagens de adultos que comungam de um ou mais aspectos dessa existência infante, o que corrobora a ideia de que ela ultrapassa a restrição de fase inicial da biografia humana para configurar-se como forma de existência que, não obstante esteja ali radicada, permeia nosso vir a ser. Aqui, alguns contos com protagonistas adultos, notadamente "O espelho" e "Presepe", trouxeram luz a lugares simbólicos que a imagem infante tece na literatura de Rosa.

Na conclusão, de caráter sempre provisório, retomamos aspectos gerais para apontar ainda uma abertura - fio de sutil sentido que atravessa as crianças de Rosa enquanto "detentoras de um segredo", do qual emerge a alegria daqueles que sabem algo, para além dos limites da aparência. Neste segredo, que não nos cabe devassar, parece residir o triunfo de uma realidade outra, "mais alta... Mais certa?"8, à qual o infante tem maior acesso do que a maioria dos adultos razoáveis.

Espera-se que o leitor, ao adentrar as próximas páginas, se permita um senso de descoberta, de jogo e alegria; que elas lhe possam dar um olhar que revela o velho de novo, nesse maravilhamento infantil sempre vivo, tão vivo que o próprio autor precisou reinventá-lo: "Maravilha: vilhamara!" (ROSA, 2016, p. 135). E que o estudo, mesmo constrangido pela lógica racional que o gênero impõe, lhe ofereça menos concepções estanques acerca do tema e das personagens e mais sua qualidade infante, passível de transformação e abertura, com o ímpeto de celebração que imbuiu certamente a criação destes pequeninos por seu autor, ele, sim, "metafisicamente grande".

\footnotetext{
${ }^{8}$ Frase do conto "Desenredo", de Tutaméia, Terceiras estórias (1969, p. 40)
} 


\section{Capítulo 1. No encalço de coisicas diminutas}

\subsection{Carência ou potência: olhares para a infância}

O tema da infância sempre contou com vasta expressão na tradição da literatura mundial, e suas abordagens foram as mais variadas. De um lado, podemos vê-lo imbuído de aura quase mágica, numa radiância que, se flerta com certas idealizações, explora aspectos genuínos e singulares dessa existência: Ela é o doce país de sonhos ao qual o poeta almeja retornar, fonte de memória e inspiração de sua arte; forma de existência autêntica, que os posteriores processos de socialização vêm a deturpar; experiência legítima de liberdade e criatividade, de olhar ingênuo e atitude lúdica diante da existência; dom de encanto inaugural com os seres, as coisas, a linguagem; um lugar de existência originária perdido pelos adultos, radicado numa experiência mais participativa do que analítica com o mundo, cuja proximidade com a natureza - seus bichos, plantas, minérios - por um lado ressalta a relação predominantemente sensorial dos pequenos com o entorno e, por outro, confere-lhes aguçada intuição e potência demiúrgica, na crença viva de que seus desejos, palavras e ações têm real poder sobre o mundo. ${ }^{9}$ Quem não reconhecerá no Peter Pan de J.M. Barry (1911) essa matriz de infância eterna, em que o desejo e ausência de medo dotam o sujeito de liberdade absoluta, capaz de criar seu próprio mundo e concretizar pelo pensamento inclusive a capacidade de alçar voo? Ou Tom Sawyer (1876) e Huckleberry Finn (1884), de Mark Twain, cuja aura mais terrena, não obstante, apresenta-nos a vida como uma sempre nova e excitante sucessão de aventuras. A infância como o lugar em que a autenticidade e criatividade do sujeito faz frente a todos os ditames e enquadramentos sociais encontrou plena expressão em Pipi Meia Longa (1945), personagem de Astrid Lindgren, cuja subversão extrema não destoa de seus impulsos de bondade e generosidade. Na literatura de língua portuguesa, lembremos ainda a Isabel de "A floresta" (1968), de Sophia de Mello Breyner Andersen, cujo desejo imaginativo possui

\footnotetext{
${ }^{9}$ As imagens de infância aqui elencadas foram extraídas de Um outro mundo: a infância, de Marie-José Chombart de Lauwe, estudo de viés psico-sociológico sobre as representações da infância em vasto corpus da literatura francesa. Embora não disponhamos de análise desta dimensão que abarque a literatura mundial, breve observação das produções literárias brasileiras desde o romantismo até o pósmodernismo nos permite vislumbrar a recorrência dos mesmos temas, donde a extrapolação da comparação.
} 
tal força de concretização que, ao construir uma casinha para um anão nas raízes de uma árvore, ele, de fato, ali aparece.

Diante de tal carga positiva, não é de admirar que o processo de deixar a infância tenha sido retratado, tantas vezes, na chave da dor, focalizando-se na literatura esse momento de passagem, de "queda do paraíso" de seus protagonistas que, por variados motivos, deverão comprometer a liberdade, a autenticidade, a imaginação criativa, a sensibilidade poética, o encanto e pasmo inicial com as coisas. Ser adulto é já saber, já conhecer, já opinar; não há lugar para descobrir o novo de novo. E os pequenos se esforçam por ser adultos, porque destes é o poder e o conhecimento, o domínio dos códigos e regras necessários para pertencer à sociedade... e, talvez, o sentimento mais forte no ser humano - aqui Clarice Lispector faz coro aos psicanalistas -, seja o de pertencer ${ }^{10}$. Cabe ao olhar artístico matizar as nuances dessa dor; personagens como nosso "Menino do Engenho", de José Lins do Rego (1932), são acompanhados em sua saída da infância, com o sacrifício de muitos dos comportamentos e estruturas psíquicas propriamente infantis, e não sem episódios de sofrimentos, mas não são deformados em seu núcleo constitutivo, podem guardar ainda algo de alegria, bondade, espontaneidade em seu adultecer. No tema da "infância roubada", porém, as agruras da vida ou crueldade dos homens a que são expostos alguns pequenos podem ser tão intensas a ponto de deformá-los em sua qualidade infante, fazendo-os perder pouco a pouco a espontaneidade e a alegria, sua natural curiosidade e, nos casos mais tristes, sua fé em si mesmos e no mundo. Ainda assim, se foram os fatores externos os responsáveis por tal perda, a imagem daquele conjunto de características luminosas inatas aos pequeninos permanece; quiçá devamos a Rousseau e seu mito do "bom selvagem" este sentimento da inocência e bondade inatas às crianças?

Contrariando Rousseau, porém - e certamente chocando nossa sensibilidade do século XXI, cujo empenho nas áreas da pedagogia e psicologia infantil se voltou para dar à criança tratamento especial, que nutrisse suas potencialidades positivas - a literatura também pôs diante de nós a maldade infantil. Crianças traquinas, portando um quê de maldade, não são raras. Há o famigerado Pedro Malasartes, junto de Juca e Chico, de Wilhelm Busch, cujas traquinagens têm um fundo de crueldade. "Les Malheurs de Sophie", da Condessa de Ségur (1859), tem uma Sophia peralta, inspiração

\footnotetext{
10 "Um amigo meu, médico, assegurou-me que desde o berço a criança sente o ambiente, a criança quer: nela o ser humano, no berço mesmo, já começou. Tenho certeza de que no berço a minha primeira vontade foi a de pertencer" (1999, p. 110)
} 
para “Os desastres de Sofia” brasileiro, de Clarice Lispector (1964), cuja protagonista traz algo de requinte psicológico à tortura que opera tanto nos outros quanto em si mesma. Um grau acima, encontramos a criança essencialmente má, criada em ambiente afável, cercada de adultos bondosos, extremosos, e que, não obstante, extrai prazer em atormentar pequenos e grandes, em torturar animais, em ver o sofrimento alheio; são personagens que nos confrontam com o Mal metafísico, sem explicação social, econômica ou psíquica, de que o menino Valtêi, em um dos causos narrados em Grande Sertão: Veredas, de Guimarães Rosa (1956), é exemplo acabado.

A literatura não deixou de abarcar, portanto, faces ambíguas da infância, e é válido lembrar que estamos lidando sempre com o olhar adulto, distanciado, em relação a essa forma de existência que ele mesmo já habitou, mas de que pode encontrar-se separado por breve vala ou largo abismo. Menos do que retratos de um estágio de desenvolvimento humano, as personagens infantis literárias se plasmam no entrecruzamento de impressões, desejos, projeções, memórias pessoais desse tempo atravessadas muita vez pela carga de um imaginário simbólico de que se fizeram impregnar. Por isso mesmo, não se pode prescindir da consciência de uma determinada perspectiva a filtrar, para o leitor, em cada obra, a imagem infante que lhe é dada.

O olhar para a infância - como o olhar para qualquer coisa - tem um tempo e um espaço. Do ponto de vista histórico, Phillipe Ariès, em seu clássico História social da criança e da família, parece ter sido um dos primeiros a apresentar um caminho de construção do que chamou o "sentimento da infância". Este, que praticamente inexistiria até o século XIII, passa a evoluir, segundo Ariés, a partir do século XIV, finalmente estabelecendo-se um reconhecimento do infante em suas particularidades e a importância de dedicação aos cuidados e à educação deste no século XVIII. O historiador atribui a indiferença da sociedade, e mesmo dos próprios pais, em relação às crianças pequenas principalmente às altas taxas de mortalidade infantil da época, pelo que "as pessoas não podiam se apegar muito a algo que era considerado uma perda eventual." (1981, p. 57). Recolhendo relatos de pais que perderam seus filhos em tenra idade, dentre eles os dos célebres Montaigne e Molière, Ariés percebe como tal indiferença é patente, concluindo que "a opinião comum devia, como Montaigne, 'não reconhecer nas crianças nem movimento na alma, nem forma reconhecível no corpo'" (1981, p. 57). O Malthusianismo e a expansão das práticas contraceptivas no século XVIII teriam feito desaparecer definitivamente este sentimento de "desperdício necessário" da mortalidade infantil. 
É certo que alguns pontos do estudo de Ariés não deixaram de sofrer sua parcela de críticas ou questionamentos, e mais do que nunca nosso olhar contemporâneo tende a ver com ressalvas a parcialidade dos documentos históricos que nos chegaram; afinal, como afirmar que uma mãe, após as transformações e laços profundos que se criam ao longo da gestação, parto, amamentação e cuidados, seria "indiferente" à morte de um filho? Temos os relatos íntimos dessas mulheres? Elas ousariam escrevê-los - aquelas que porventura fossem alfabetizadas? Não nos interessa aqui, absolutamente, enveredar por tais discussões históricas, mas o estudo de Ariés nos traz, sim, algo valioso para nosso percurso. Na transição do suposto sentimento de indiferença para a preocupação com a infância, ele aponta, ao longo do século XVII, o surgimento do reconhecimento do caráter de "inocência" infantil pela sensibilidade adulta paralelamente ao surgimento da literatura pedagógica; e ressalta a coexistência de dois sentimentos aparentemente contraditórios em relação a ela. De um lado, uma concepção moral toma a inocência, nas imagens de "fragilidade" e "debilidade" dos pequenos, em chave negativa, porque oposta à faculdade da racionalidade, já tão valorizada pelo espírito clássico; a tarefa pedagógica estaria justamente em eliminar esta fragilidade, desenvolvendo na criança o caráter e a razão. De outro lado, esta inocência é associada à pureza divina, em sua impecabilidade, sua ausência de paixões e vícios, vista agora não como fragilidade, mas como "estado ilustre" - nestes aspectos guardando inclusive uma superioridade em relação aos adultos já "conspurcados" -, o que colocava a educação dos pequeninos como a primeira na fila das obrigações humanas, no dever de preservar tal inocência da sujeira do mundo (1981, p. 146-147).

O paradoxo se apresenta: a infância deveria então, a um só tempo, ser preservada, salvaguardada, assegurando-se assim sua pureza inocente, mas também "livrada" deste estado inocente anterior ao desenvolvimento pleno da razão, da moral e dos bons costumes, num esforço pedagógico que forçaria a criança a "tornar-se mais velha do que realmente é". Mas Ariès já ressalta que tal contradição existe apenas na mentalidade do século XX (e perdura na do XXI, arriscaríamos dizer), cujo sentimento de infância se caracteriza por uma associação desta ao primitivismo e pré-logismo, ideia que surgiu com Rousseau. Após o Iluminismo, o Romantismo passa a atacar veementemente o lugar de supremacia da razão sobre as demais inteligências humanas, a sentimental, emotiva, estética, motora, sensória, intuitiva, etc.; o fascínio do modernismo pela forma de pensamento e expressão primitiva segue na mesma esteira e, sob essa luz, a inocência infantil como potência deve-se, em parte, a que essas demais 
faculdades humanas, nos infantes, ainda predominam sobre o racionalismo. No século XV até o XVII, porém, as noções de inocência e razão não se opunham. Em um manual de civilidade francês de 1671 lê-se, como condição de educação bem sucedida, "se a criança viveu como um homem." (1981, p. 146-147).

Essas duas visadas para a infância, como estado de carência ou de potência, é que nos interessam, pois elas parecem de alguma forma estar no horizonte das construções das personagens literárias pequeninas; da conjunção entre a visão de mundo do autor e o tempo em que ele se insere nascerá a motivação pela escolha por uma ou por outra e a forma de trabalhá-las, seja a partir de influências do imaginário religioso cristão ou valorização do primitivismo e seu modo de pensamento que escapa à soberania do racionalismo cartesiano, por exemplo. Como vimos no esboço de representações literárias anteriores, pode-se pender mais para uma visada ou para outra, mas também conjugá-las para tensionar a ambiguidade constitutiva dessa existência infante.

Podemos ainda delineá-las, em linhas gerais, da seguinte forma: como potência, vislumbra-se o infante não como um "projeto de adulto", mas como uma forma de existência em si mesma, já plena no seu modo de ser e de se relacionar, que se mostra, em certos aspectos, superior à dos mais velhos. O infante já é: criativo, autêntico, espontâneo, curioso, plenamente presente em cada ato e gesto, dotado de liberdade e intenso gozo com a descoberta da vida. ${ }^{11}$ Oposta a ela está a carência, a visada da "falta", da "insuficiência", da "incompletude". Para a sociedade que concebe a criança como o "adulto por vir", a existência infante significa o que "ainda não é", o que não se integrou em pessoa de fato, uma incompletude, portanto, oposta à totalidade. Nesta chave, muitos foram os autores que flagraram a infância como um estado de sofrimento, no estranhamento, angústia e desorientação da criança na relação com o mundo administrado adulto, em suas experiências de querer e não poder, sentir e não saber se expressar, lutar para apreender conceitos e códigos contraditórios, estar à mercê do poder físico e psíquico dos seus "superiores"; Infância, de Graciliano Ramos, nos

\footnotetext{
${ }^{11}$ Lembro aqui depoimento de Daniel Munduruku, da etnia do índios munduruku, autor de livros infantis, professor e mestre em educação pela Universidade de São Paulo, que, em palestra proferida na Biblioteca Hans Christian Andersen de São Paulo, em 24 de outubro de 2015, comentou: "A única pergunta que vocês fazem constantemente às suas crianças e que nós jamais pensaríamos em fazer às nossas é "O que você vai ser quando crescer?", porque, para nós, a criança não "vai ser", ela já é; e porque ela já é hoje não temos a menor dúvida ou preocupação quanto ao adulto que ela será".
} 
conduz por todas estas dores, e, em menor escala, mas em narrativa não menos pungente, o conto "Tempo da camisolinha", de Mario de Andrade.

O próprio termo "infante", vale lembrar, sofreu variações em seu uso e significado. Ariés cita Le grand proprietaire de touts choses, livro VI, texto medieval em que se delineiam correspondências entre as fases da vida e os planetas:

"A primeira idade é a infância que planta os dentes, e essa idade começa quando a criança nasce e dura até os 7 anos, e nessa idade aquilo que nasce é chamado enfant (criança), que quer dizer não falante, pois nessa idade a pessoa não pode falar bem nem formar perfeitamente suas palavras, pois ainda não tem seus dentes bem ordenados, como dizem Isidoro e Constantino." (1981, p. 36)

Está claro que tal definição hoje nos é risível em sua fidelidade poética, mas nada científica, ao imaginário das correspondências, posto qualquer observador constate que a partir dos dois anos, com dentes bem formados ou sem, os infantes são bastante falantes! Mas guardemos, da imagem acima, a ideia de que os infantes não podem "falar bem". No final da Idade Média, o termo era usado indistintamente para referir-se a meninos pequenos ou a adolescentes, e estava menos ligado à idade do que à ideia de dependência - tanto que ele e seus sinônimos eram utilizados nas relações feudais ou senhoriais para se referir à parte subserviente ou, na sociedade em geral, aos homens de baixa condição ${ }^{12}$. Somente durante o século XVII é que o termo "infante" se restringiu a seu sentido moderno, que abrange dos dois anos (antes disso temos o "bebê"), até os dez, onze, que hoje identificamos com categoria ainda mais recente, a pré-adolescência.

Do ponto de vista histórico, portanto, seja no aspecto etimológico, seja nas variações de uso, o termo aqui se nos afigura predominantemente associado à "falta": falta de fala, falta de independência e autonomia, falta de status social. Mas, se cruzamos a linha para o campo literário - e justamente nele tendo de trair a etimologia! - os infantes serão, para mais de um autor, como vimos, o oposto da "falta": seres dotados de forma mais alta de "ser"; não meros detentores de inocência invejável e

\footnotetext{
12 Vemos claramente a sobrevivência deste mecanismo linguístico de "rebaixamento social" no trato de "menino", "rapaz", "moço" que certos indivíduos ainda dispensam àqueles que desempenham funções lastimavelmente consideradas "menores" na sociedade, como as de garçom, motoboy, gari, lixeiro...
} 
objetos de cuidado dos adultos, mas seus próprios mestres. A epígrafe de Kierkegaard, na introdução deste trabalho, é um tal exemplo; adianta-se inquestionavelmente a ver no infante modo de existência plena que, se aprendida pelos adultos, alça-os a estado de ser que supera a mesquinhez cotidiana, atingindo grandezas metafísicas. O heterônimo pessoano de Alberto Caeiro, apesar de profundamente antimetafísico, guarda algo desse estado de ser infante que revela inequívoca superioridade em relação aos adultos - tanto que foi eleito pelos demais heterônimos, inclusive pelo próprio ortônimo, como o seu "mestre". E o mestre de Caeiro, não é, por sua vez, a criança? A "Eterna Criança, o deus que faltava" (2001, p. 40), na figura do Menino Jesus, é celebrado pelo poeta - em imagens até hoje algo escandalosas para a sensibilidade cristã - por todas as qualidades mais propriamente infantis da espontaneidade e liberdade, alegria simples com brincadeiras ou traquinagens, curiosidade e dom do olhar límpido e inaugural para o mundo; sua inocência é matizada por extrema atualidade do existir, para além de todo pensamento que nos projeta no passado ou no futuro, que racionaliza as experiências em lugar de vivê-las, experimentá-las: "a única inocência é não pensar" (2001, p. 27).

Se trouxemos estas últimas imagens, é porque nosso percurso com os infantes rosianos se alinhará, em mais de um momento, com elas, levando-nos a sondar o que há de "metafisicamente grande" na forma de existência infantil para Guimarães Rosa. Aliás, no domínio da arte, a pergunta cabível seria o que há na representação dos infantes que nos leva a esfera de grandezas outras, a ponto de nelas desvelarmos uma "maestria". Vale convocarmos alguns saberes do campo do desenvolvimento humano que dão lastro a traços recorrentes já apontados na representação artística dos infantes, e que encontraremos igualmente nos pequeninos de Rosa, antes de adentrarmos sua obra.

\subsection{Psicanálise e filosofia: pistas sobre o existir infantil}

Comecemos por uma impressão certamente comum a todos quando nos recordamos de nossa infância mas que, ao mesmo tempo, diz de uma experiência completamente inalcançável e hoje inconcebível para nós: a infância é o tempo fora do tempo. Não apenas porque ser infante nos parece ter sido outra existência, num tempo tão longínquo e destacado de nossa biografia, mas porque nos seus primórdios, do 
nascimento até os dois anos, segundo Piaget ${ }^{13}$, o tempo é, para nós, simples duração interior, não se aplica a fenômenos exteriores ao sujeito; não podemos concebê-lo como campo que englobe os acontecimentos em si mesmos, independentes de nossas ações; e, mesmo em relação a elas, somos incapazes de conceber um "antes" e um "depois". Quando infantes, portanto, experimentamos a existência enquanto atualidade quase absoluta. A noção precisa de tempo transcorrido, ou mesmo a capacidade de conceber um tempo futuro, de forma, por exemplo, a planejar uma sucessão de ações dentro de determinado cronograma, será difícil ou praticamente inexistente até os três, quatro anos. Essa adesão tão profunda ao presente é o que dá aos infantes também sua profundidade existencial, sua invejável capacidade de inteireza contemplativa: nada neles se fragmenta. Se olham uma planta, todo o seu ser, desde um fio de cabelo até a ponta dos pés, olha a planta, a ponto de suspender as fronteiras - melhor, não as haver ainda criado - entre si e o mundo... olhar a planta é, para os infantes, ser com a planta, porque naquele instante nada mais existe ${ }^{14}$.

Isso se dá também porque, nesse estágio inicial não há, de fato, uma capacidade representativa, uma "função semiótica" como a chamou Piaget, que possibilite atribuir um significante diferenciado - uma linguagem, imagem mental, gesto simbólico - a um significado, seja um objeto, um conceito, um acontecimento, de forma que tudo só existe, para nós, em ato, em presença (1999, p. 47). Daí, decerto, existirmos também em um presente absoluto ${ }^{15}$. Com a capacidade representativa, as coisas passam a existir para nós e a atuar em nós mesmo em sua ausência física, e tem início o longo trajeto de abstração, com suas dores e delícias. A ele devemos a fragmentação existencial, expulsos do presente pelas memórias do passado ou preocupações e anseios pelo futuro, mas também graças a ele ganham-se a linguagem e o jogo simbólico. Este último

\footnotetext{
${ }^{13}$ Para estudos mais detalhados sobre os estágios da construção do tempo na psique infantil ver Dolle, Jean-Marie, Para compreender Piaget, Instituto Piaget, Lisboa, 2005, p. 173.

${ }^{14} \mathrm{Na}$ literatura, Clarice Lispector, em seu "Menino a bico de pena", diz a impossibilidade adulta de apreender esse estado de pura atualidade: "Sei que é impossível desenhá-lo a carvão, pois até o bico de pena mancha o papel para além da finíssima linha de atualidade em que ele vive." (1996, p. 64)

${ }^{15}$ Em termos conceitualmente mais rigorosos, considerando os estudos de Hanna Segal (2013), na esteira das teorias de Melanie Klein, há, sim, uma função representativa mesmo nos estágios iniciais do desenvolvimento. Ela denomina "equação simbólica" este processo em que o infante projeta externamente seus objetos internos, identificando-os com partes do mundo externo que passam a representá-los. Porém, sendo que o self não os experimenta como substitutos, mas como o próprio objeto original, permanece uma indiferenciação entre a coisa simbolizada e o próprio símbolo - daí diferenciar tal processo com o termo "equação simbólica", que está no gérmen da formação de símbolos. O que nos interessa, no entanto, é a vivência que a criança tem do mundo: seja nos termos de Piaget ou de Segal, permanece o fato de que a indistinção entre coisa simbolizada e símbolo faz com que essa imediaticidade da experiência se mantenha, posto a criança viva o símbolo como o objeto em si mesmo, sem o distanciamento que a abstração representativa lhe proporcionaria.
} 
compreende as brincadeiras, que predominam até os seis anos, em que o mundo inteiro se transforma em representação: uma folha é um pato, uma lata é um homem, e a boneca ou os bichos de pelúcia passam a receber a projeção das alegrias ou dos conflitos afetivos recentemente vividos pelos pequeninos; no caso daquelas, a projeção serve para alargar-lhes na alma a existência; no caso destes, para reelaborá-los segundo os próprios desejos.

Mesmo a linguagem, de função representativa por excelência, instrumento indispensável para a adaptação social, transmitida à criança em suas formas prontas, fixas, de natureza coletiva, ganha nas mãos, antes, na boca, dos infantes expressões próprias, seja por assimilação generalizadora: "Ah, e você vai conosco ou sem nosco?" (ROSA, 2001, p. 169), seja por construções de fato originais, invenções de termos ou modos de dizer: "Ele xurugou?" (p. 67). Nestes processos, vislumbramos a criança ainda dando à sua subjetividade supremacia sobre um sistema "exterior" imposto a ela, fazendo da língua um meio de expressão próprio, de significantes maleáveis à sua criatividade, dóceis à sua vontade, adequados à expressão de seus anseios e experiências internas. Nessa abertura criativa para a linguagem, os pequeninos encontram um respiro da experiência tão custosa de adaptação ao real, de não mais ser com o mundo - ou o mundo ser com eles - mas de saber-se separado de tudo e, pior, ter de se haver com a supremacia da realidade exterior em meio às coações e sanções que vão sendo impostas por adultos e contingências do entorno.

Lembremos, para entender esse sofrimento e também uma condição fundante do modo de existir dos infantes, o que estudos psicanalíticos denominaram "ilusão de onipotência". Segundo Freud (1987) e Winnicott (1975), o bebê, em seus primeiros momentos de existência, não tem formada psiquicamente a consciência - nem de si, nem do outro. Quando é assaltado pelos fenômenos, tanto internos quanto externos, só pode tomá-los como parte de si, como nascidos de si mesmo. O mundo somos nós. Daqui deriva uma ilusão de controle mágico sobre o real; como exemplo, ao sinal de fome, um seio que aparece é interpretado pelo infante como se magicamente tivesse sido criado por ele próprio no momento de sua necessidade, já que, psiquicamente, não há nada "não-eu", e por ele "desfeito" uma vez que esta foi atendida. Tão forte é essa experiência de unidade eu-mundo, e o senso de poder sobre a realidade dela advindo, que a criança, até seus cinco ou seis anos de idade, mesmo com tal separação já bem delimitada na psique, ainda será profundamente autorreferente, guardando algo da concepção mágica segundo a qual os seres e as coisas se movem em harmonia consigo. 
É o próprio Piaget que cita, a esse respeito, exemplos de inúmeros sujeitos de quatro a seis anos que creem que a lua os segue, ou até que eles a obrigam a segui-los, quando se movem (1999, p. 96).

As teorias psicanalíticas nos ajudam, assim, a dar lastro algo palpável para o que poderia parecer apenas delírio poético de nossos autores: A criança como ser mágico, dotado de poderes sobre a realidade em atos e palavra, em jorro criativo permanente, existindo em um tempo fora do tempo, cuja capacidade de atualidade e identificação se faz tão radical a ponto de se abrir para dimensões cósmicas de pertencimento, união com os seres e as coisas, acesso à grande beleza do mundo. A luz e a beleza permeiam a experiência infantil a partir dessa capacidade de assombro e espanto do olhar virgem para as coisas e os seres; ser infante é viver perpetuamente o instante genesíaco, num transbordamento delirante que inunda todos os âmbitos da existência desses que são, arquetipicamente para nós, o eterno começo. Nada se fixa, tudo recomeça a cada minuto... "era uma vez", e mais uma, e mais uma, em êxtase permanente, como se fosse a primeira (e não é, de fato, a primeira, ainda que seja a milésima segunda?). Gaston Bachelard critica nossa visão do universo fabuloso da criança como advindo e devedor das "fábulas narradas pelos adultos", invertendo a chave para um aprendizado do fabuloso pelos adultos a partir das crianças: "Para redescobrir a linguagem das fábulas é necessário participar do existencialismo do fabuloso, tornar-se corpo e alma de um ser admirativo, substituir diante do mundo a percepção pela admiração. Admirar para receber os valores daquilo que se percebe." (1988, p. 113). E receber, aqui, não seria "ter em si", portanto "ser um com"?

Outro aspecto que invariavelmente desponta quando sondamos nosso imaginário sobre a infância enquanto "metafisicamente grande" é o profundo senso de liberdade. Malgrado os inúmeros cerceamentos, em maior ou menor grau a depender do contexto histórico e sociocultural, que o ambiente e os adultos impõem aos pequenos, alguém seria capaz de negar a avassaladora liberdade interna que tem o infante? Em alguma outra forma de existência ela é mais profundamente vivida? Os infantes estão "antes da queda". Regidos ainda predominantemente pelo princípio do prazer, não se constrangem diante de seus desejos nem hesitam frente a suas indagações ou pensamentos. Com que liberdade eles enunciam aquilo que nós, adultos, nos envergonhamos de haver sequer pensado! Essa autenticidade, que tivemos de comprometer em troca do processo de socialização, e que somos forçados a ir também lapidando nos pequenos com os quais convivemos, não deixa de ser objeto de nostalgia. 
Várias são suas facetas: liberdade linguística, como já mencionamos, na manipulação criativa com o sistema que nos vai sendo entregue; liberdade de ação, para o bem e para o mal, vale lembrar, desde a alegria de chafurdar em poças de lama até nefastos golpes de raiva e violência contra algo ou alguém; e liberdade de pensamento, não apenas na ausência de filtros morais a plantar recalques psíquicos, mas principalmente na atividade imaginativa sem limites: uma casa inteira feita de doces, um menino que foi buscar flores na lua, um fiozinho de água que vira um lagarto... A profusão de devaneios a que os infantes com facilidade se entregam e que, como já mencionamos, a partir de certa idade plasmam em brincadeiras e jogos simbólicos, é, para Freud, gérmen da atividade criativa dos próprios escritores ${ }^{16}$.

Se a função arquetípica da literatura, como queria Northrop Frye, é a de "visualizar o mundo do desejo não como uma fuga da 'realidade', mas como a forma genuína do mundo que a vida humana tenta imitar" (1973, 182-183), mundo este que seria o de sonhos que plasmamos com nossos desejos, a imagem do infante, ser inaugural cujos desejos, impulsos autênticos e criativos não se encontram ainda cerceados pelo princípio da realidade, nos dá a possibilidade de existência mais próxima da liberdade interna e externa que podemos conceber. Não dirá outra coisa Gaston Bachelard: "Quando sonhava em sua solidão, a criança conhecia uma existência sem limites. Seu devaneio não era simplesmente um devaneio de fuga. Era um devaneio de alçar voo" e, mais adiante, "Na nossa infância, o devaneio nos dava a liberdade. E é notável que o domínio mais favorável para receber a consciência da liberdade seja o devaneio." (1988, p. 94)

Sem pretender esgotar as imagens - e longe de achar que elas explicam o postulado de Kierkegaard, maravilhoso porque sempre aberto -, deixaremos este esboço de algumas das qualidades da existência infantil como fios que se poderão trançar à nossa figuração dos infantes de João Guimarães Rosa.

\subsection{O Olhar de Rosa: "Infância é coisa, coisa?"}

"Infância é coisa, coisa?", interroga-se o narrador de "Nenhum, nenhuma" (ROSA, 2001, p. 98), após esforço labiríntico pelos meandros de reminiscências

\footnotetext{
16 "Será que deveríamos procurar já na infância os primeiros traços da atividade imaginativa?", indaga o psicanalista em seu "Escritores criativos e devaneios" (1908 [07], p.149)
} 
remotas, em que nos embrenha junto consigo na tentativa de reconstituir os fragmentos de algo vivido nos primórdios de sua existência de menino. Por mais que as memórias de infância se revistam de aura quase irreal - o inevitável jogo entre memória, imaginação e desejo ${ }^{17}$ mergulhando em incerteza onírica tanto do que tentamos fixar como fato constitutivo de nosso ser, mas a que, de fato, não logramos dar consistência (é, afinal, coisa, coisa?!) - o "adulto que se lembra", que revisita o passado, é, para nós, experiência atual e familiar, variando apenas a frequência com que uns e outros a ela se entregam.

O que se faz, no entanto, distante, elusivo, já raro se não totalmente ausente de nossas vivências na idade adulta é o "estado de ser" infantil. Porque todos sabemos se não pelos conhecimentos psicanalíticos aqui já esboçados, ao menos pelo empirismo de nossas biografias - que o existir infantil guarda não poucas diferenças do existir adulto. Quer busquemos nos poetas ou nos manuais de psicologia, essas imagens de um outro modo de ser emergem inequivocamente para nós, configurando a infância quase como uma vida outra, "Um outro mundo"18. Não por acaso a pergunta citada acima doa-nos certa inquietação. Há, afinal, algo de fugidio, que nos escorre das mãos quando tentamos tocar esse "outro mundo", ao mesmo tempo familiar e distante. O que é ele? Sabemos nomeá-lo, dizer-lhe a substância, nós que algum dia já o habitamos? Quem sabe ele esteja além do tempo e espaço, e precisemos de algo que não as mãos para tocá-lo. A pergunta inicial persiste, e guarda semelhança à que faz Carlos Drummond de Andrade a respeito do próprio Guimarães Rosa: "Ficamos sem saber o que era João / E se João existiu / de se pegar" ${ }^{19}$. Infância e Rosa possivelmente se pertençam em mais de uma volta desse mistério e, apesar de sabiamente já se ter dito, acerca de Grande Sertão: Veredas, que "mistérios admitem unicamente culto e celebração" (PASTA, 1999, p. 62), espera-se que estas próximas páginas possam descortinar sentidos e imagens da figuração da infância na obra rosiana, sem deixar de celebrá-la.

Rosa não "fala sobre" a infância, ele a coloca diante de nós, e isso se deve, em grande parte, à escolha do ponto de vista narrativo. Ele nos dá mais propriamente a experiência do existir infante não na primeira pessoa que rememora sua infância, mas na terceira pessoa das narrativas cujas crianças são protagonistas. Dante Moreira Leite

\footnotetext{
${ }^{17}$ A respeito do entrelaçamento entre memória, desejo e imaginação, ver MENESES, 2004, p. 33.

${ }^{18}$ Parte do título de Marie-José Chombart de Lawe, Um outro mundo: a infância.

19 "Um chamado joão", poema publicado no Correio da Manhã de 22 de novembro de 1967, três dias após a morte de João Guimarães Rosa.
} 
já observara, com relação à personagem Miguilim, que a escolha do foco narrativo na terceira pessoa convencional da ficção não era arbitrário, mas necessário, "pois a história não poderia ser narrada pelo herói a não ser como evocação, e isso (...) destruiria o seu núcleo fundamental, que é a perspectiva da criança." (2002, p. 263).

O infante não narra a si mesmo. Ele está por demais ocupado, como infante, em existir. O distanciamento narrativo significaria já ter saído da experiência de infância enquanto tal e a estar narrando. Para nos mergulhar na atualidade dessa experiência, Rosa nos dá um narrador em terceira pessoa, ora observador, ora onisciente, mas sempre imbuído de infância. Seja pelo discurso indireto livre, que nos cola no olhar, pensamento, sentimento e sensações dos pequeninos, seja no manejo da linguagem, em sua profusão de diminutivos, nas típicas construções sintáticas, morfológicas ou lexicais daqueles que estão às voltas com a descoberta desse universo, seja, ainda, na lente que filtra o mundo a partir das dimensões e perspectivas próprias da criança, o que se constrói para nós por meio da onisciência seletiva é esse mergulho irresistível no aqui-agora do ser infante, descortinando-nos algo estranho a nosso modo de existir que, entretanto, já nos foi familiar.

O tema não conta ainda com vasta bibliografia, mas tampouco escapou à crítica que a literatura rosiana é, em muitos aspectos, atravessada por ele. Seja porque o lugar de infância do autor - o sertão mineiro - não só é palco de seus enredos mas imbuiu todo o imaginário e concepção de mundo de sua literatura; seja porque sua escrita se faz infante, numa ludicidade com as palavras que torna a língua recém-nascida a cada momento; ou ainda porque o primado da intuição sobre a razão, tão caro a Rosa, é domínio mais próprio dos pequeninos, que em suas perguntas e formulações invariavelmente desconcertam-nos pelo não-senso e subversão da lógica cartesiana. Henriquieta Lisboa tenha talvez sido uma das primeiras a ressaltar a importância da infância quer como tema, quer na qualidade de presença ou vivência constitutiva da visão de mundo do autor e, assim, elemento determinante de toda a sua obra:

"Há uma aura de tresloucada candura ao longo de suas páginas as mais realistas. A alegria inexplicável das cousas amanhecentes, a descoberta da natureza, o despontar do pensamento através de palavras anteriores à lógica, [...] o jogo das metáforas, a própria filosofia matreira dos primitivos, personagens de sua dileção, os quais devem o que pensam ao que veem, tocam e degustam, o bárbaro 
e o primevo, tudo isso remonta à infância do autor, tudo isso demonstra a sua faculdade de prolongar a infância" (1983, p. 171).

Seu sensível artigo procura vislumbrar esse "sentimento de infância" que permeia o estilo do escritor em seus aspectos primitivos, intuitivos, no jorro de alegria criativa, no olhar inaugural para o mundo, encaminhando suas reflexões para aproximações entre a figura do menino e a do poeta. Já Vânia Maria Resende parte da concepção de arte esboçada pelo autor no extremamente metalinguístico "Aletria e Hermenêutica" - primeiro dos contos-prefácios de Tutaméia, ressaltando que a coerência da "estória" rosiana repousa nas fronteiras do imaginário, acima ou à margem do plano da convenção (da "história"), seu sentido sendo atingido apenas por um suprasenso, e, nesta perspectiva, vislumbra o Menino de Rosa, cujo pensamento primitivo, afim ao do sertanejo, desarticula conceitos preestabelecidos e inverte noções linearmente concebidas (RESENDE, 1988, p. 26).

É curioso que o tema não raro seja abordado com certa timidez pela crítica. Lisboa, apesar de alçar a infância a elemento articulador de toda a escrita de Rosa, inicia seu artigo em tom reticente, apontando temas de muito mais vulto no conjunto da obra, da essência metafísica à inovação estilística, das dicotomias bem-mal, medo-coragem à integração do regional no universal. Queremos partir desse timidez para descortinar aproximações talvez insuspeitadas entre alguns desses grandes temas rosianos e a tão diminuta figura infantil.

Uma das grandes linhas de força da obra rosiana, e que talvez chegue o mais perto possível de "dizê-la" (porque defini-la seria não apenas ingenuidade, mas rematada tolice) é a "mistura". O mundo rosiano, desde sua estreia com Sagarana, em 1946 é, por excelência, o "mundo misturado" ${ }^{20}$ : mistura de áreas de conhecimento variadas, amalgamadas igualmente na criação das obras de fôlego e no menor dos contos, que levou a uma profusão de abordagens críticas - geográfica, social, histórica, antropológica, psicanalítica, filosófica, metafísica, religiosa, semiótica, musical; mistura de tradições distendidas no tempo e no espaço, ocidentais e orientais, desde as fontes literárias mais remotas (os Upanixades hindus, por exemplo), às mais modernas (a interlocução com seus contemporâneos brasileiros e estrangeiros é notável); mistura

\footnotetext{
${ }^{20}$ Expressão que se encontra na boca do jagunço-narrador Riobaldo, e que Davi Arrigucci Jr. aproveita como título de seu famoso artigo "O mundo misturado: romance e experiência em Guimarães Rosa". Novos Estudos CEBRAPE, no 40, novembro 1994, pp. 7-29
} 
linguística, que abarca em seu português estruturas das muitas línguas modernas e antigas que ele dominava; mistura de gêneros em suas obras e, aquela que tanto ocupou seus críticos, a consagrada mistura entre regional e universal. Como se sabe, o universalismo de Rosa, a impregnar tanto seu estilo quanto suas temáticas, se fez assente, não obstante, no regional, naquele "mistério geográfico" ${ }^{21}$, seu burgo bem Minas, com a particularidade de seus tipos, paisagens, cheiros, cores, vozes, costumes e artes populares, o que levou um de seus primeiros e até hoje mais lúcidos críticos a plasmar o termo super-regionalismo: a superação do regionalismo - e realização do universal - pelo próprio regionalismo (CANDIDO, 1989, p. 161).

O mesmo Antonio Candido, mal um ano transcorrido da estreia de Grande Sertão: Veredas, entregou-nos chave para a compreensão não só deste romance, mas de toda a literatura rosiana: o princípio geral da reversibilidade, ancorado numa profusão de ambiguidades nos mais variados planos narrativos do romance, e que opera "um deslizamento entre os polos, uma fusão de contrários, uma dialética extremamente viva - que nos suspende entre o ser e o não ser para sugerir formas mais ricas de integração de ser" (1983, p. 305). O "mundo misturado" de Rosa nos apõe constantemente a coincidência dos opostos: regional e universal, sensível e inteligível, sabedoria e loucura, deus e o diabo, algoz e redentor estão indissoluvelmente entranhados, pactados ao longo de toda sua obra, num estilo que é, também ele, constituído no signo da reversibilidade, permeado de ambiguidades, duplos sentidos, sendo ainda a um tempo popular e erudito. Epítome deste encontro de contrários, a imagem da lemniscata - a fita de Moebius, cujos lados de dentro e de fora coincidem não por acaso encerra o romance Grande Sertão: Veredas. Essa reversibilidade sem fim dos polos é, certamente, uma das principais constantes norteadoras da literatura rosiana, e se desdobra em praticamente todos os seus elementos narrativos: personagens, enredo, tempo, espaço, narradores, além da própria linguagem, resvalando inclusive para os paratextos - título, subtítulo, epígrafes, índices - vide o jogo de reversibilidade que o autor propõe entre os gêneros atribuídos aos textos de Corpo de Baile, e, em experiência ainda mais extrema, entre textos e paratextos nos dois índices de Tutaméia: Terceiras Estórias.

É operação que deflagra o paradoxo, desafia o princípio da não contradição, e parece a serviço da convicção profundamente arraigada na obra rosiana de que as coisas

\footnotetext{
${ }^{21}$ Como Rosa se refere a Cordisburgo em seu discurso de posse na Academia Brasileira de Letras.
} 
não são as coisas, a realidade objetiva não tem a supremacia sobre a subjetiva ou metafísica. "Tudo é a ponta de um mistério, inclusive os fatos. Duvida? Quando nada acontece, há um milagre que não estamos vendo" (ROSA, 2001, p. 119). Não bastasse afirmação assaz peremptória de um de seus narradores, o próprio Rosa o confessa a seu entrevistador português, Fernando Camacho: "A minha concepção do mundo não é de verdade material, objetiva... Essa realidade objetiva não existe, eu não acredito nela, é apenas aparência. A verdade, a verdadeira realidade é outra coisa para além desse mundo objetivo, outra coisa..." (CAMACHO, 1978, p. 48). E para chegar a esta "outra coisa", a lógica hegemônica, linear, cartesiana, calcada nas leis da física mecânica, que opera com binômios excludentes e molda desde o pensamento individual até as estruturas sociais contemporâneas, não serve. Há que se romper com ela; há que se dizer, com a filosofia hermética, "o que está em cima é como o que está embaixo, e o que está embaixo é como o que está em cima"; "o semelhante e o dessemelhante são uma só coisa"22. Há que se ir para uma "terceira margem"... E toda literatura que já se interessou por ela teve certa predileção, igualmente, pelas figuras marginais: loucos, bêbados, criminosos, prostitutas... crianças. Com eles, Rosa nos aponta, nesta nossa Caverna de Platão, as frestas, por vezes inauditas, que "escancham os planos da lógica" a revelar-nos, subitamente, a "coerência do mistério geral, que nos envolve e cria" (ROSA, 1969, p. 4). O infante rosiano, veremos, ultrapassa o que geralmente identificamos como estágio inicial de desenvolvimento humano para colocar diante de nós uma forma de existir que chamaremos "original", "originária" ou "infante" na qual se entrecruzam paradigmas existenciais e simbólicos que fazem dela uma fresta muito particular para o mistério geral; e é essa particularidade que nos interessará.

\subsection{1 "No princípio era...": relações com a Origem no existir infantil}

O infante-início, amanhecer da existência, é forte em nosso imaginário simbólico; se podemos dizer que ele participa de uma dimensão "originária" e "original", devemos compreender que, na literatura rosiana, desdobra-se desse aspecto um estado de ser no mundo do qual mesmo personagens adultas podem comungar, para

\footnotetext{
${ }^{22}$ Três Iniciados, O Caibalion: estudo da filosofia hermética do antigo Egito e da Grécia. Tradução: Rosabis Camaysar. São Paulo, Editora Pensamento, 1997, pp. 63 e 85.
} 
cuja particularidade e potência concorrem tanto o "não ser ainda" quando o "já ser plenamente".

Um ponto de vista sociocultural nos daria nessa "origem" infantil uma existência aquém dos códigos partilhados, quer sejam valores, costumes, moralidades, normas de comportamento ou de linguagem. Psicanaliticamente "anterior" à castração, o infante vive todavia o imperativo do princípio do prazer, não comprometido com o jogo de concessões para equacionar mundo subjetivo e objetivo, desejo e realidade. Nas representações rosianas, este "não ser ainda" reverte-se em "ser plenamente": apesar de querer fazer parte do mundo, e se esforçar por compreender suas leis, o infante ainda não constrangido por elas tem no trânsito entre sua subjetividade e todo o entorno campo infinitamente mais aberto. Subverte relações hierárquicas, se arrisca para além dos limites e perigos concebidos pelos adultos, maravilha-se com a novidade do mundo e descoberta da linguagem em manejo inusitado, poético, e dá a seus desejos expressão livre e criativa; aquém da lógica materialista ou utilitária, sua ação ou pensamento podem ser regidos ora por sentimentos ora por sensações, empatias, admiração da beleza, prazeres simples, desejo de expressividade e criatividade gratuitas... No "não ser ainda" há, portanto, um "alargamento do ser", uma expansão de possibilidades existenciais.

Encontramos na antropologia fortes lastros que irmanariam o pensamento e forma de existência ditos "primitivos" ao que aqui identificamos como essa dimensão "originária" do infantil em Rosa. Não foram poucos os estudiosos que se inquietaram ou maravilharam com a forma de ser e pensar de povos antigos ou ditos "primitivos". Dentre eles, Lévy-Bruhl tem o mérito de ter sido dos primeiros a identificar tipos de formulações mentais distintas entre os homens, levando a antropologia a rever o filtro eurocêntrico a partir do qual se interpretava o pensamento "primitivo" como inferior, incapaz de abstração ou lógica. Ainda que o título de uma de suas obras seja "As funções mentais nas sociedades inferiores" e ele chame de "pré-lógico" o raciocínio de tais povos, salienta, porém, que isso não significa um estágio anterior, na historicidade humana, ao aparecimento do pensamento lógico, posto não se tenha conhecimento de grupos de seres humanos cuja mentalidade não obedecesse a leis da lógica, mas que, não sendo anti-lógica nem alógica, essa mentalidade "não se atém antes de tudo a evitar a contradição, como a nossa. Ela obedece primeiramente à Lei da Participação, que é indiferente à contradição" (2015, p. 55). Dentro dessa Lei, o primitivo não vê os objetos de sua experiência como uma corrente de causas e efeitos nem os considera fenômenos 
diferentes, mas "[...] percebe uma participação recíproca entre tais objetos, de maneira que um deles não pode mover-se sem afetar o outro. Isto é, não se pode tocar em um sem influir no outro e sem que o próprio homem mude." (BRUHL, apud PAZ, 2012, p. 124). Esta experiência de inter-relação de objetos, planos e forças que consideraríamos distintas e desconexas, Bruhl considera mística, no sentido estrito da crença em forças, influências, ações imperceptíveis aos sentidos e, no entanto, reais. Nada é percebido com um fenômeno puramente físico, mas mantém ao mesmo tempo uma existência visível, outra invisível.

Os infantes partilham em muito dessa relação mística com o mundo e, principalmente, comungam desse estado original que não é, de forma alguma, compreendido como um estágio inicial a ser superado, dentro de uma noção linear da história e certa medida qualitativa de transcurso do tempo, mas um estado de existência e forma de pensamento em si mesmo ${ }^{23}$, que opera por lógica outra, na qual a razão cartesiana não tem predominância, mas sim o princípio de participação, de contradição, a existência de forças e planos outros que se cruzam para além do visível. Sabemos o quanto esse primitivismo interessou à literatura modernista e o quanto a literatura rosiana encontra-se impregnada de princípios que desafiam a racionalidade. $\mathrm{O}$ primeiro dos quatro prefácios de Tutaméia, "Aletria e Hermenêutica" é, se pudermos ousar defini-lo, um tratado sobre o não-senso. Publicado inicialmente sob o título de "Risada e Meia" na revista Letras e Artes (04.05.1954), sofreu consideráveis acréscimos e alterações antes de integrar o livro. A mudança do título parece redimensionar o humor, que poderia à primeira vista ser tomado como "rasa coisa ordinária", para dar-lhe relevo como "instrumento de análise, nos tratos da poesia e da transcendência", uma vez que ele "escancha os planos da lógica, propondo-nos realidade superior e dimensões para mágicos novos sistemas de pensamento" (ROSA, 1969, p. 3). Assim é que, dentre uma série de anedotas cujo fundo humorístico reside no não-senso, principalmente pela "presentificação da ausência" ou "existência do inexistente" (o garotinho perdido que pergunta ao guarda "o sr. não viu um homem e uma mulher sem um meninozinho assim como eu?!" (p. 5); ou a impagável legenda de uma foto normal da Baía de Guanabara: "O Argos, à entrada da barra, quando ainda não se o via..." (p. 8), há uma lista de dizeres

\footnotetext{
${ }^{23}$ Esta é também a ressalva feita por Karl Kerényi ao abordar o tema da "Criança Divina": "Quando recorri às designações "primordial" ou "arcaico", empreguei-as no mesmo sentido do estudo ' Die Geburt der Helena', sem uma acepção cronológica. Com essas expressões indico uma qualidade atemporal que pode surgir nas épocas posteriores assim como nas mais antigas." (2011, p. 95-96)
} 
das crianças, referidas como "notáveis intérpretes", em que o olhar novo, não moldado pelo senso comum ou pelo conhecimento racionalista do mundo, em suas relações de causa e efeito, nos dá, por exemplo, a indagação do menininho: "Por que será que sempre constroem um morro em cima dos túneis?", ou a exclamação da menina que, em visita ao protético, ao descobrir uma dentadura articulada, grita: "- Titia! Titia! Encontrei uma risada!" (p. 8), mas também a explicação bastante metafísica dada por um pequeno a respeito da morte do gato: "O gato saiu do gato, pai, e só ficou o corpo do gato" (p. 9).

Estar "aquém" da racionalização aproxima os pequeninos rosianos daquilo que Peter Pál Pelbart (1993, p. 93) denominou "desrazão". Não sendo "loucura", posto os infantes não se alienem da realidade e, em seu processo de aprendizado, querem, como dissemos, experimentar o mundo e se inserir nele, eles todavia mantêm um trânsito, uma relação de vai-vem entre a lógica do pensamento hegemônico e essa outra lógica, o "pensamento do exterior", segundo o denominou Foucault (1966), o qual toca em tudo aquilo que está, justamente, "fora" de nossas formatações culturais e sociais, ou mesmo do que nossa cognição racional é capaz de apreender e nomear: $\mathrm{O}$ caos da linguagem, as dimensões noturnas do ser, as experiências metafísicas, o mistério da existência... tudo aquilo, enfim, que esfumaça as fronteiras nítidas entre o eu e o outro, escapa aos nossos sistemas de classificação e que, por isso, coloca-se no campo do indizível. É, portanto, ainda uma vez, um alargamento das possibilidades de ser que se apresenta. Enquanto a visão objetiva/materialista reduz o mundo à dimensão visível, com suas leis mecânicas e biológicas fixas e inexoráveis - somadas, em muitas sociedades, ao imperativo do utilitarismo -, e o racionalismo impõe o princípio da não contradição, da linearidade causal, os pequeninos, como os primitivos, vivem o mundo e lhe atribuem significação a partir de múltiplas outras realidades - emotivas, sensoriais, estéticas, intuitivas, imaginativas... o mundo aparece ainda "encantado" e, sob a égide mística, os objetos e seres detém forças e dimensões invisíveis que escapam aos adultos. Mas tal alargamento se dá, também, como aponta Bruhl, porque na raiz da lógica hegemônica contemporânea está o postulado primeiro do estado de separação, absoluto e irredutível, entre o "eu" e o "tu", o sujeito e o mundo - ou mesmo entre quaisquer corpos no tempo e no espaço; sujeito e objeto não se implicam, não há espaço para contradição, a coincidência dos opostos. Enquanto isso, nas formas de existência originais dos infantes, impera um estado fusional, uma participação tão plena do sujeito em tudo o que existe que ele assume, por vezes, aspecto quase mágico. É um estado 
que existiu de fato nos primórdios de nossa psique (como lembramos a partir dos conceitos de "ilusão de onipotência" e "controle mágico sobre o real", segundo a psicanálise), que parece ecoar o que Romain Rolland chamaria, em suas correspondências com Sigmund Freud, de "sentimento oceânico" (1993, p. 303-304) sentimento pleno de participação no mundo, de dissolução do "eu" na integração com tudo o que existe ${ }^{24}$.

Rompidas as barreiras entre o eu e o outro, compreendemos a capacidade extremamente intuitiva das pequeninas personagens rosianas e sua profunda relação com a natureza, em especial com os bichos, a ponto de lograr, em dados momentos, uma comunicação de fato com eles. Não por acaso praticamente todos os contos com protagonistas infantes em Rosa são pontuados pela presença de animais. Eles trazem o "ser aí", estado originário de existência pura, atualidade absoluta, ainda mais vivo do que as crianças, e com eles estas se relacionam a partir de um corpo que é todo presença, instinto, sensação.

Há, por fim, uma dimensão simbólica, mesmo metafísica, desse lugar-existência originário dos infantes. Ele é o lugar de onde viemos mas, ao mesmo tempo o lugar para onde retornamos. Dentro da filosofia platônica, que abarca o reencarnacionismo de Píndaro, a alma que nasce ingressa na existência terrena a partir da alta esfera onde contemplou as Formas Ideais, já tendo assim visto tudo o que há a conhecer, portanto, o que aqui vive como "aprendizado" não passa de "rememoração" do já sabido ${ }^{25}$. Os infantes, por estarem dele mais próximos, parecem ter na obra rosiana uma "lembrança" 26 ainda mais viva de saberes outros, de um lugar "alhures", raramente acessado pelos adultos. Karl Kerényi, perseguindo o tema da Criança Original a partir de inúmeros motivos mitológicos, chega na aproximação entre alguns deuses em suas figurações infantes ${ }^{27}$ e o mundo subterrâneo, o reino dos mortos; tanto o infante - que

\footnotetext{
${ }^{24}$ Freud interpreta o que é para Rolland experiência mística-transcendente, como resquício desses estagios psíquicos vividos nos primórdios da existência individual, iniciando seu "O Mal estar na civilizaçāo" [1930] com referência à carta do amigo sobre o sentimento oceânico.

${ }^{25}$ Deixamos aqui apenas este esboço breve da teoria da reminisção platônica, que será aprofundada na análise do capítulo 2 .

${ }^{26}$ Destacamos duas dentre as referências de ecos platônicos em infantes rosianos: "[...] era que nem uma espécie de cinema de desconhecidos pensamentos; feito ele estivesse podendo copiar no espírito idéias de gente muito grande." (2001, p. 227); "O menino se lembrava sem lembrança nenhuma. Molhou todas as pestanas." (2001, p. 229)

${ }^{27}$ Ele ressalta, no início de seu estudo, que a mitologia nunca é uma "biografia" dos deuses; suas figurações infantes trazem "um deus na plenitude de sua forma e poder e, por isso, o modo de pensar biográfico - o pensamento em idades da vida como se fossem fases de uma evolução - fica de fato excluído. [...] são, como toda figuração possível do ser - formas de expressão do divino." (2011, p. 45)
} 
ingressa na vida - quanto o moribundo prestes a deixá-la, encontram-se próximos a esse "lugar" de onde viemos e para onde vamos; o primeiro pode ser descrito como "ainda não excluído do não ser e, apesar disso, já sendo", enquanto o segundo "ainda não excluído da existência e, apesar disso, não mais sendo." (2011, p. 106-107)

Ingressar no mundo a partir dessa Origem, enigmática porque inapreensível, a um só tempo aquém e além da existência tal como a conhecemos, é experimentar tudo o que para os adultos é da ordem do "conhecido" como "desconhecido", novo, num olhar que re-descobre e re-vela o mundo a nós e, ao mesmo tempo, ter com o "desconhecido", o informe e insondável de onde viemos e para onde nos dirigimos, uma relação de familiaridade e proximidade. As crianças encarnam essa reversibilidade não por ação intencional, influências ou circunstâncias externas, como seria o caso quiçá dos loucos, bêbados ou jagunços, mas pelo caráter inaugural e inocente próprio de sua existência mesma, que é também o que as fazem invariavelmente se revestir de uma aura de Graça. Rosa, no mesmo prefácio que acima mencionamos, ressalta que a palavra "graça" não por acaso guarda três sentidos, "de gracejo, de dom sobrenatural e de atrativo" (1969, p. 3). Os seus infantes são, em mais de um conto, flagrados em alguma dessas dimensões: nos gracejos que praticam e dizem ou na forma engraçada com que o narrador os descreve (curioso que em ambas esteja compreendida muitas vezes uma "inversão lógica"): " - Antes falar bobagens, que calar besteiras..." (2001, p. 169); "Brejeirinha se instituíra, um azougue de quieta, sentada no caixote de batatas." (2001, p. 167); nos dons sobrenaturais que manifestam - Nhinhinha, que materializa seus desejos pela fala, ou Tiãozinho, cujo sentimento e pensamento se transfere para os bois do carro; e na experiência da beleza que tão insistentemente perpassa as vivências infantis - o encantamento do Menino diante do Peru e do Tucano, ou o de Miguilim ao ver finalmente nítido o Mutum através dos óculos do doutor do Curvelo. E poderíamos ainda derivar de "graça", como atributo tão próprio dos pequenos, o sentido de "gratuidade"; eles, cujas ações e desejos raramente têm uma motivação utilitária, de caráter comercial, se relacionam com os seres e coisas movidos por afeto ou admiração gratuitos - o amor de Miguilim pela cachorrinha Pingo de Ouro, já quase cega, portanto, "inútil" do ponto de vista do pai, que a dá a estranhos, ou Nhinhinha, que faz chover não para por fim aos estragos da seca, mas simplesmente porque deseja o Arco-Íris; aliás, a gratuidade é, ela própria, uma das dimensões de que participa a beleza.

A partir de seu lugar de existência inaugural, portanto, os pequeninos rosianos se fazem "metafisicamente grandes" enquanto detentores de outra lógica existencial, e 
aqui eles se encontram com um dos princípios rosianos centrais que apontamos: serão imagem potente da Coincidentia Oppositorum ${ }^{28}$, figuração do infinitamente grande no infinitamente pequeno, conjunção do princípio e do fïm da existência; veremos, ao longo dos contos analisados, que quanto mais novos os protagonistas - mais próximos à Origem -, mais aparentados se fazem aos grandes mistérios existenciais. A mesma imagem se encontra em Tutaméia, quando, em glossário insólito ao final do último dos quatro prefácios, Rosa fornece para o título, entre as definições de nonada, baga, ninha, quase nada, a de mea omnia, "todas as minhas coisas" ou "tudo meu" (1969, p. 166); o nada é tudo, no micro está o macro - e vice versa - a obra rosiana não se cansa de nos lembrar.

Assim é que, se retomarmos o fio deixado por Philipe Ariés, em que vislumbramos as duas concepções históricas aparentemente paradoxais acerca do sentimento da infância, quais sejam, a inocência infantil como carência/falta ou como potência/plenitude, teremos, em Rosa, a coincidência desses polos: a carência de normas linguísticas será potência poética; a "falta" de racionalidade, abertura para dons sobrenaturais; a incipiente noção de temporalidade é a graça do instante e atualidade quase absolutos, o ainda precário ancoramento no princípio de realidade logrará moldar o mundo a partir do princípio do prazer; também o revés da moeda pode se apresentar, e a um momento sublime de coragem ou heroísmo da personagem pequenina se reforça seu caráter diminuto, seu dever de obediência aos adultos, sua angústia diante da descoberta da finitude, da morte... Como "coincidem", na obra rosiana, elas acabam operando como grandezas proporcionais: quanto mais os infantes são mostrados sob o signo de "coisicas diminutas", maiores se revelam a nossos olhos.

\subsubsection{O móvel mundo: existência e linguagem}

Sentemos à janelinha do avião, ao lado do Menino, e contemplemos... nesta simples imagem, Rosa plasma no olhar da criança, este "quase nada de gente", outra das grandes linhas de força de sua obra. Saber o "móvel mundo" é encarnar uma existência profundamente afeita à lógica da reversibilidade constante, na imagem de lastro algo taoísta da vida como movimento contínuo, rio em lemniscata sem fim no qual o homem navega mal quando aferrado a sistemas por demais fechados, lógicas

\footnotetext{
${ }^{28}$ A professora Adélia Bezerra de Meneses opera este conceito para analisar a personagem Diadorim em seu Cores de Rosa (2010, pp. 38 - 42).
} 
deterministas, ânsia por controle e saber como domínio da realidade. Em caderno inédito do autor, lê-se:

Até as coisas, em si, mudam a cada instante (digo em si, porque, quanto ao sistema de inter-relações cósmicas, todas as noções deviam ser revistas, quase cada dia: jogada a primeira bomba atômica, até a noção de rabo de boi e do capim teriam que se transformar no Chapadão do Urucuia ou no Pantanal do Mato Grosso). Viver é uma operação mágica. Por isso, também, porque a vida recomeça a cada minuto, é indispensável a gente se fazer como menino, ser como criança - "Amen dico vobis, nisi conversi fueritis, et efficiamini sicut parvuli, non intrabitis in regnum coelorum". (Apud SPERBER, 1982, p.78) 29

A condição do infante é móvel por natureza. E tal mobilidade tem a ver, antes de tudo, com a linguagem. Já apontamos a necessidade de reinterpretar o conceito de infante que, etimologicamente, seria o ser anterior à fala ou o que não fala. Um dicionário etimológico de práxis docente, porém, nos dá outra definição do termo: "Aquele que acaba de ingressar no mundo ainda inominado, tão novo quanto os modos de sua identificação." (CASTELLO \& MARISCO, 2007, pp 51-52). Não aquele que "não fala", mas aquele que possui uma "outra fala", condizente com a experiência adâmica inaugural, em que tanto o mundo quanto as palavras para nomeá-lo estão, ainda, por serem descobertos: o infante tem na linguagem campo aberto, não formatado ou enrijecido, significante e significado ainda não se uniram em indissolúvel matrimônio e as palavras ou formulações sintáticas estão em estado gasoso, suspenso, disponíveis a intercâmbios criativos dos mais vários. Relembremos a definição medieval de Isidoro e Constantino ${ }^{30}$ segundo a qual o "enfant", até os 7 anos, não pode "falar bem" ou "formar perfeitamente as palavras". Nos adjetivos que grifamos está nossa chave: o infante não fala bem ou perfeitamente segundo a gramática normativa, dentro da perspectiva da língua enquanto sistema utilitário de comunicação. Porém, se deslizamos para o campo poético, da língua viva, plástica, inventiva, que se amolda e

\footnotetext{
29 "Em verdade vos digo: se não vos transformardes e vos tornardes como criancinhas, não entrareis no reino dos céus."

${ }^{30}$ Citada na primeira parte deste capítulo.
} 
recria para dar conta da experiência subjetiva, talvez seja a maioria dos adultos que "não fala bem", nem "forma perfeitamente as palavras". Esta experiência que alia a percepção sensorial do novo - um alumbramento contemplativo - à formulação de um vocábulo igualmente novo, que dê conta do vivido, é parte da poética rosiana desde Sagarana ${ }^{31}$ quando, no episódio do "rol de reis", do conto "São Marcos", o narrador nos diz da irresistível necessidade de criar um vocábulo inédito, absurdo, e bradá-lo: "Ó colossalidade!", diante da impactante experiência de "descobrir, no meio da mata, um angelim que atira para cima cinquenta metros de tronco e fronde" (1978, p. 238).

A carência e imperfeição linguística dos infantes revelam-se, na visão rosiana, potência deste "ser infante" para uma existência viva e movente, "nascida a cada momento para a eterna novidade do mundo." (PESSOA, 2001, p. 26), diríamos com Alberto Caeiro; porque, se "a linguagem e a vida são uma coisa só" (LORENZ, 1991, p. 83), como queria Rosa, então aquele cuja linguagem encontra-se não de todo formatada é aquele para quem o mundo e a realidade podem ser recriados a cada instante, para quem a vida, de fato, recomeça a cada minuto, configurando o viver verdadeira operação mágica.

O infante é, neste ponto, o que mais se aproxima da concepção rosiana da língua enquanto seu elemento metafísico, seja por fazê-la indissociável da existência em seu processo fluido, sem parada, que jamais se cristaliza, mas também porque operá-la é, para Rosa, recriar o mundo, repetir o instante genesíaco em ato quase divino:

O bem estar do homem depende do descobrimento do soro contra a varíola e as picadas de cobra, mas também depende de que ele devolva à palavra seu sentido original. Meditando sobre a palavra, ele se descobre a si mesmo. Com isto repete o processo da Criação. (LORENZ, 1991, p. 83)

A revelação de seus procedimentos formais continua:

... há meu método que implica na utilização de cada palavra como se ela tivesse acabado de nascer, para limpá-la das impurezas da

\footnotetext{
${ }^{31}$ Agradeço ao Prof. Dr. Erich Soares Nogueira por relembrar-me a passagem de Sagarana para este contexto da fala inaugural infantil em sua relação com a própria poética rosiana.
} 
linguagem cotidiana e reduzi-la a seu sentido original. (LORENZ, 1991 p. 81)

Devolver à palavra seu sentido original. O método de operar a linguagem é explicitado aqui como um "retorno à origem", ao "estado de pureza" das palavras... a uma "infância" da língua? Aqui, "tornar a língua nova" guarda também uma coincidência de opostos: o novo enquanto "novidade", "recém-criado", coincide com o momento em que a língua era "nova", "recém-nascida", portanto, o momento mais antigo, remoto, de sua existência ${ }^{32}$. Novamente a ambiguidade misteriosa desse "estado original" infante, que o crítico e filósofo Benedito Nunes ressalta ao analisar as jovens personagens de Rosa:

A infância ou juventude é neles um estado de receptividade, de sabedoria inata, e tem duplo sentido: por um lado, remoto e nebuloso passado, que se confunde com as origens, e, por outro, prenúncio de um novo ser, ainda em esboço, que advirá do que é humano e terrenal. (NUNES, 2013, p. 65-66)

Essa ambiguidade é o que muitas vezes doa inquietante estranheza aos pequeninos rosianos, uma jovialidade imbuída de velhice, uma leviandade séria, inocência prenhe de saberes e, em certos casos, uma aura de irrealidade que os faz mais pertencentes a um "lá" do que a um "aqui". Ressaltemos que esta é característica mais própria da tenra infância, enquanto os que põem o pé para fora do primeiro setênio já se fazem "esboço" mais nítido do que há de vir daquilo que é "humano e terrenal".

Não raro, na obra rosiana, a Alegria e a Beleza emergem desse estado de existência, ambas qualidades profundamente ligadas ao senso de plenitude, de integração vivido pelos pequeninos e que, para alcançarmos, dependemos de uma inversão, uma ruptura para a qual nos abre a "graça" em seus múltiplos sentidos - de gracejo, dom sobrenatural, atrativo, gratuidade; tal ruptura está também nos postulados metafísico-filosóficos, místicos, mencionados inicialmente: "as coisas não são as coisas", a realidade imanente não resume nem determina inexoravelmente a existência,

\footnotetext{
${ }^{32} \mathrm{O}$ que elucida para nós o paradoxo de um autor de linguagem espantosamente inovadora dizer-se não "revolucionário", mas "reacionário" da língua (LORENZ, 1991, p. 84)
} 
mas se faz relativa, cambiante, influenciável por outras leis e planos; o mundo e a linguagem de repente se revelam "grande brinquedo", passível de transformação a todo instante, vividos em seus mistérios pelos infantes em relação intuitiva e participativa, não analítica e utilitária, no saber igualmente místico professado pelo próprio autor, de que "A verdade, a verdadeira realidade é outra coisa para além desse mundo objetivo, outra coisa..." (CAMACHO, 1978, p. 48).

Aqui cabe uma ressalva, sempre necessária no trato com a literatura rosiana que, em mais de uma ocasião, dividiu a crítica entre a abordagem metafísica/universalista ou realista/regionalista e que, diante de afirmações como a exposta acima, levou alguns a julgá-la por demais fantasiosa, tendendo à alienação. Na magistral análise comparativa das perspectivas que norteiam a obra de Graciliano Ramos e a de Guimarães Rosa, o crítico Alfredo Bosi já apontou na obra de ambos o valor documental, o testemunho regionalista e aguda observação que reconstitui a realidade sertaneja brasileira, porém reconhecendo no primeiro um "historiador da angústia", separado da matéria de que trata por uma ideologia determinista, ao passo que o segundo aproxima-se de seu mundo mineiro mediado pela religiosidade popular, cuja crença na "ordem do transcendente abre horizontes sem fim e, no devir da fantasia, alguma coisa sempre pode acontecer." (2003, p. 36). As agruras, carências ou violências podem até ser ponto de partida, contexto situacional, mas jamais são o ponto de chegada inexorável e definitivo, nem ocupam o centro em torno do qual orbitam as narrativas rosianas. O que nelas governa o mundo é uma lei outra, mais alta, que não a das contingências; é um telos, um sentido final que se delineia e abarca em sua realização inclusive o percurso de carência ou sofrimento, bastando, como diz Bosi, que os seres mesmo mais despossuídos, "ponham em ação as potências indestrutíveis do desejo." (2003, p. 47). Na mesma esteira segue Kathrin Rosenfield, que aponta o realismo das cenas de Rosa, sua substância palpável, como corolário concreto e objetivo de uma realidade de outra ordem, metafísica e/ou ficcional, afirmando que "O que conta nesta outra realidade é tão só a aspiração de viver para além daquilo que é conhecível e cognoscível, para além da experiência empírica." (2001, p. 88).

Assim é que as molduras de condições sociais, políticas e econômicas do Brasil, tão caras ao regionalismo de 30, são em Rosa o caminho mesmo para aquilo que transcende o social, lançando seus leitores nas poeiras do sertão e em reflexões filosóficas sobre o sentido da existência e do ser. O próprio autor aponta, em correspondência com seu tradutor italiano, a temática metafísica-religiosa como valor 
mais alto em sua literatura (2003, p. 90); tal metafísica, ele nos diz, não prescinde da realidade, do contexto concreto e regional, antes nele se apoia como degrau de transcendência:

[...] Eu gosto de apoio, o apoio é necessário para a transcendência. Mas quanto mais estou apoiando, quanto mais realista sou, você desconfie. Aí é que está o degrau para a ascensão, o trampolim para o salto. (CAMACHO, 1978, p. 47)

Dentro desta compreensão, igualmente, olhamos para as figurações de infância na obra rosiana, pois é certo nos depararmos com protagonistas pequeninas que se confrontam com paisagens inóspitas, carência de necessidades básicas, alimentos, higiene, vestuário, educação, saúde - lembremos a morte do Dito, irmãozinho querido de Miguilim, que uma simples vacina antitetânica teria evitado - e de cuidados ou afetos da parte do mundo adulto. Conseguimos, à primeira vista, distinguir enredos em que seus infantes se tecem de maior carga simbólica, o elemento mágico ou metafísico acentuando-se em sua constituição, enquanto outros nos levam a acompanhá-los em experiência de aprendizagem do mundo, com suas dores, violências e injustiças, porém, mesmo nestes últimos, o ser infante, na forma de existência que ele figura para a concepção de mundo rosiana, aponta para algo além do imanente, numa subversão da lógica que apõe o sentido transcendente das experiências humanas, quer em seu gozo quer em sua dor.

Se lembrarmos que a alegria gratuita ${ }^{33}$ é um dos grandes aprendizados que perpassa a obra rosiana, poderemos agora compreendê-la não como um delírio alienado que nega o sofrimento ou as agruras do mundo, mas como o dom daqueles capazes de entrar em relação com o mundo objetivo a partir da percepção de algo para além dele. E talvez seja este o "segredo" que muitos dos pequeninos parecem deter, mesmo sem saber que o sabem, e de que muitos dos adultos se veem privados; essa diferença de percepção constitui um dos pontos de tensão entre os dois universos invariavelmente

\footnotetext{
${ }^{33}$ Evoquemos Riobaldo "O que Deus quer é ver a gente aprendendo a ser capaz de ficar alegre a mais, no meio da alegria, e inda mais alegre ainda no meio da tristeza! (2001, p. 334), Lalinha, em Buriti "Meu dever é alegria sem motivo... Meu dever é ser feliz..." (2016, p. 240) e ainda a suprema lição do Dito, criança com a sabedoria daqui e de lá, à beira da morte: "Miguilim, Miguilim, vou ensinar o que agorinha eu sei, demais: é que a gente pode ficar sempre alegre, alegre, mesmo com toda coisa ruim que acontece acontecendo. A gente deve de poder então ficar mais alegre, mais alegre, por dentro...!" (2001, p. 119)
} 
figurados nos contos com protagonistas pequeninos. A literatura rosiana abertamente dá a estes últimos a primazia sobre os adultos, e difícil é não lembrar, em tais lances, depoimento do próprio autor acerca destas relações em sua infância:

Não gosto de falar da infância. É um tempo de coisas boas, mas sempre com pessoas grandes incomodando a gente, intervindo, estragando os prazeres. Recordando o tempo de criança, vejo por lá um excesso de adultos, todos eles, mesmo os mais queridos, ao modo de soldados e policiais do invasor, em pátria ocupada. Fui rancoroso e revolucionário permanente, então. (PEREZ, 1991, p. 37.)

Retomemos: a coincidência dos opostos, a reversibilidade entre polos, ambos eixos estruturais das narrativas rosianas, encontram, como vimos, aporte em sua figuração das crianças e no que o estado infantil comunga com a concepção metafísica da linguagem pelo autor. Tanto essa reversibilidade/mobilidade quanto a potência demiúrgica de "reinaugurar o mundo" tomam parte em ainda outra dimensão da obra rosiana na qual língua e infância se tocam nas fronteiras da alegria e da beleza: a da língua enquanto jogo. Mencionamos que Freud aponta a escrita e o devaneio como atividades criativas análogas ao brincar infantil - e mesmo este como uma semente daquelas (1907 [8], p. 149); mas talvez poucos tenham realizado literariamente, em tão variados níveis, a alegria do brincar como Guimarães Rosa. Em trecho de sua famosa entrevista ao crítico alemão Gunter Lorenz, ele nos declara: "Os livros nascem quando a pessoa pensa; o ato de escrever já é a técnica e a alegria do jogo com as palavras" (1991, p. 144).

Não por acaso sua inventividade linguística foi objeto primeiro de pasmo dos leitores e de análise dos críticos. O jogo imagético e sonoro, os deslocamentos e quebras sintáticas, a mescla de vocábulos e estruturas gramaticais de diversos idiomas, a recuperação de arcaísmos, recriação de provérbios, além dos próprios neologismos, fazem jus ao menino de nove anos que já mesclava "jogo" e "língua" quando, nos intervalos das partidas de futebol nas ruas de Cordisburgo, sentava-se no meio fio com uma gramática alemã comprada por ele mesmo aberta ao colo, simplesmente, como nos confessa, "[...] por inato amor às palavras recortadas de exatas consoantes: tais como kraft e sanft, welt e wald, e gnade, e pfad e haupt e schwung" (MEYER-CLASON, 1968, p. 7). E se podemos confiar nos relatos de seu tio, Vicente Guimarães, que 
regulava em idade com o sobrinho e era seu muito companheiro de infância, os livros eram o principal "brinquedo" de Rosa nas férias em Cordisburgo ${ }^{34}$.

Afinal, a brincadeira é, como a escrita, ato que inaugura mundos e, uma vez posta em movimento, segue curso fluido, contínuo, quiçá indefinidamente (há um quê de estranha impossibilidade afim ao término tanto do narrar quanto do brincar - e só quem os realiza sabe da dificuldade em encerrá-los!); este movimento é feito, também, de outras mobilidades/reversibilidades: para a criança que brinca, uma folha é um barco, que é um jacaré, que é um pássaro, que é um menino, que é... Nos infinitos desdobramentos, deslocamentos e sobreposições de significantes e significados, reside uma delirante alegria partilhada entre brincantes e escritores em seus atos criativos; e Rosa tem, indisputadamente, um manejo magistral de tais expedientes desde as micro até as macro estruturas da língua. De uma infinidade de exemplos, vejamos mínima $\operatorname{amostra}^{35}$. De neologismos e estrangeirismos, recriações lexicais em procedimentos vários, temos "O mato - vozinha mansa - aeiouava" (NS, p. 143); "certificativo homem, de severossimilhanças" (TT, p. 112); "E, desistindo do elevador, embriagatinhava escada acima" (TT p. 104); Com susto recuou, avançou de novo, e idem, ibidem, itidem, chocou-se; e ibibibidem. Foi às lágrimas." (TT, p. 103); "Aqueles esmerados esmartes olhos, botados verdes (GSV, p. 119); "Ou - o senhor vai - no soposo: de chuva-chuva" (GSV, p. 42). De imagens figuradas e jogos sonoros: "Cheiro pingado, respingado, risonho, cheiro de alegriazinha" (CG, p. 31); "O vento é verde. Aí, no intervalo, o senhor pega o silêncio põe no colo" (GSV, p. 306); "Olhou o céu - atônito de azul" (PE, p. 54); "o silêncio saía de seus guardados" (PE, p. 54); "seu [do peru] grugrulhar grufo" (PE, p. 54). Recriações de provérbios e ditos populares: "Ele era um caso achado" (TT, p. 84); "O pior cego é o que quer ver" (TT p. 15); "Vá-se a camisa, que não o dela dentro" (TT, p. 39); "O feio está ficando coisa..." (PE, p. 195). E o período seguinte, emblemático da plasticidade de reinvenções sintáticas e morfológicas: "Que vontade era de por meus dedos, de leve, o leve, nos meigos olhos dele, ocultando, para não ter de tolerar de ver assim o chamado, até que ponto esses olhos, sempre havendo, aquela beleza verde, me adoecido, tão impossível." (GSV, p. 62) Alegria do jogo com as palavras, deveras!

\footnotetext{
34 "Brinquedos, brincadeiras quase nada. Sua atividade maior, constante, fatal, era a leitura." (GUIMARÃES, V. 2006, p. 65)

${ }^{35}$ Para facilitar as citações, usamos as seguintes abreviações: GSV - Grande Sertão: Veredas; TT Tutaméia: Terceiras Estórias; PE - Primeiras Estórias; CG - Campo Geral, NS - Noites do Sertão. Todas as referências de páginas correspondem às edições que constam na bibliografia final.
} 
Por fim, o jogo, tal como a escrita rosiana, opera numa coincidência de opostos, na medida em que se configura território algo indefinido, fugidio, difícil de "se pegar": o brincar não é nem completamente dentro nem totalmente fora do sujeito; nem pura realidade nem mera ficção; ele é o terreno em que o subjetivo e o objetivo se encontram e se confundem, em que dentro é fora e fora é dentro. O psicanalista Donald Winnicott, que se debruçou sobre o ato de brincar, compreende-o como território intermediário, "espaço potencial", nem puramente subjetivo, nem inteiramente objetivo:

[...] o brincar tem um lugar e um tempo. Não é dentro, em nenhum emprego da palavra (e infelizmente é verdade que a palavra "dentro" possui muitos e variados usos no estudo psicanalítico). Tampouco é fora, o que equivale a dizer que não constitui parte do mundo repudiado, do não-eu, aquilo que o indivíduo decidiu identificar (com dificuldade e até mesmo sofrimento) como verdadeiramente externo, fora do controle mágico $(1975, \text { p. } 62)^{36}$.

Brincar é caminhar sobre uma fita de Moebius. Para Guimarães Rosa, viver e escrever também.

\footnotetext{
${ }^{36}$ Em sua tese, Winnicott parte da concepção do objeto transicional, com o qual psiquicamente se dá no bebê a relação intermediária entre o puramente subjetivo e o objetivo, para pensar analogamente a brincadeira.
} 


\section{Capítulo 2. Tres-aventura}

\subsection{O absurdo e a graça: de massas, letras e fios}

A menorzinha das protagonistas rosianas está em conto igualmente "pequeno", de pouco mais de duas páginas, em livro cujo título traduz-se por "nonada, baga, ninha, inânias [...] quase nada" (ROSA, 1969, p. 166). Tutaméia: Terceiras Estórias, último livro publicado em vida por Rosa permanece, até hoje, um enigma aos rosianos mais ferrenhos. Elusivo desde o título, vai-se fazendo escapar ao leitor a cada página, seja na liquidez dos elementos constitutivos que supostamente deveriam se fazer mais sólidos, pontos cardeais a nortear a leitura - título, subtítulo, índice, prefácio e epígrafes vertem e revertem, mudam de lugar e de estatuto quando de sua releitura - , seja na linguagem e conteúdo dos próprios contos, cujo caráter sintético e densidade simbólica chega a graus deveras desafiadores. Na única entrevista filmada que temos do autor ${ }^{37}$, recentemente descoberta na Alemanha, quando o crítico-entrevistador perguntava-lhe sobre seu novo livro, Primeiras Estórias, comentando o salto de estilo do jorro verbal de Grande Sertão para a prosa sintética destes contos, Rosa, com sua "pinta de boi risonho", responde: "Chegarei até o hieroglifo". Em Tutaméia, ele parece estar quase lá...

O que o torna ainda mais inquietante é o fato deste "quase nada" de livro, em sua linguagem "breve" e enredos "enxutos" trazer, sob a econômica opacidade do signo/símbolo, as chaves para "quase tudo" do universo deste autor: mea omnia ${ }^{38}$. Mary Lou Daniel, muito sensivelmente, o identificou como espécie de "livro testamento", que Rosa parecia pressentir como último e, por isso, nele deu a seus leitores aquilo que "só se dá uma vez na vida..."39 (DANIEL, apud SIMÕES, s/d, p. 20).

\footnotetext{
${ }^{37}$ Entrevista com Walter Höllerer, gravada em 1962, para um canal independente de televisão, em Berlim. Trata-se das únicas imagens em vídeo do escritor, que se encontram no documentário "Outro Sertão", direção de Adriana Jacobsen e Soraia Vilela, 2013, 01h:06min)

38 "tudo meu"/"todas as minhas coisas" é uma das definições que Rosa dá ao termo "tutaméia" em glossário ao final do conto-prefácio "Sobre a escova e a dúvida" (1969, p. 166)

${ }^{39}$ Referindo-se ao último prefácio, "Sobre a escova e a dúvida", ela diz " Surpreendente me foi ler por primeira vez este prefácio, parecendo-me que o autor tocava em terreno tão íntimo como quase sagrado, inviolável; mas compreendi, ao receber a notícia de sua morte tão pouco tempo depois, que ele nos legava nessas páginas de Tutaméia algo de si que só se dá uma vez na vida, e que o dava naquele momento com plena consciência de sua mortalidade e imortalidade."
} 
O primeiro dos prefácios, e que, de fato, parece ter sido retrabalhado para servir $\operatorname{como~tal}^{40}$, nos dá, desde o título, o estranhamento, o enigma que emerge da conjunção improvável de substantivos que, em seus significados, unem prosaico e sublime, sensível e inteligível, estômago e intelecto: "Aletria e Hermenêutica". Da massa em finos fios à refinada arte interpretativa resta, a nós leitores, fazer a ponte. Neste jogo do emaranhado macarrãozinho aos fios de sentido do tecido/texto por deslindar, a regra primeira é a subversão de todas as regras: o absurdo, o paradoxo, a inversão, o nãosenso proposto a nós pelas "anedotas de abstração", postulantes de uma lógica outra, da "presença da ausência" ou "existência da não-existência", por meio da qual, nos diz o autor, podem-se vislumbrar "realidade superior e dimensões para mágicos novos sistemas de pensamento" (1969, p. 3).

Aqui o cômico de um gênero tão rebaixado como a anedota (aletria...?) é instrumento nos "tratos da poesia e da transcendência" (hermenêutica...?); humor, metafísica e arte se encontram assim conjugados, o que Rosa nos revela na polissemia da palavra "graça", com seus sentidos de "gracejo", "dom sobrenatural" e "atrativo". Ao longo do conto/prefácio (ambíguo até em sua categorização) todos os expedientes anedóticos de subversão da lógica, operados principalmente nos desvãos da linguagem, que seja, nas suas "falhas", no que escapa à possibilidade representativa ou rompe com a convenção dos signos do sistema linguístico (o passageiro sentado sob goteira em ônibus vazio, indagado sobre "trocar de lugar", que responde "trocar... com quem?" (p. 4) ou a definição do "nada" dada por meninozinho: " é um balão, sem pele..." (p. 6) em sua "presentificação da ausência" ou "representação do irrepresentável" apontam para uma conjugação de opostos que, se saltarmos do nível do significado para o do significante, reaparece igualmente no título: A-letria, a ausência da letra/palavra, e hermenêutica, a interpretação desta "letra-não-letra".

Reafirmamos: a soma de todos estes "nadas" está a serviço de um vislumbre da totalidade. O micro, pequeno, insignificante, prosaico e por vezes cômico, é porta para o macro, o sublime, "mistério geral que nos envolve e cria" (p. 4). Assim é que a criança, tutameiazinha de gente do conto "Tresaventura" - único deste livro em que figura como protagonista - , insistentemente nos confronta com a existência da não existência, no anseio por uma imagem que vacila entre ideia e realidade, pondo diante de nós, com

\footnotetext{
${ }^{40}$ Como já dissemos no Capítulo 1 do presente trabalho, após sair com o título "Risada e meia", na revista Letras e Artes (04.05.1954), foi bastante retrabalhado para integrar o livro Tutaméia como primeiro conto-prefácio da obra.
} 
seu ser criança, um enigma em narrativa, cuja graça une alto e baixo entre humor, beleza e mistério, velando e desvelando sentidos para apontar, quem sabe, a um "supra senso".

Há que se ter predisposição lúdica para ler os títulos rosianos. "Tresaventura" joga com nosso senso de estranhamento e familiaridade, tornando obscuro, pela prefixação insólita, um substantivo que já consta do vocabulário de falantes do português desde os primeiros anos escolares. "Aventura", além do mais, é gênero literário romanesco dos mais populares, ainda que dificilmente se preste ao espaço restrito do conto (que dirá de um com menos de três páginas...!); mas traz aquele conforto do conhecido. E "tres-"? "Tres-" é o enigma, tanto quanto a epígrafe de autoria incerta (Mnemônicum?), que aponta para domínios vagos ou irreconhecíveis: "No nãoperdido, no além passado...". Juntos, eles nos tornam novamente crianças diante do desconhecido, curiosas, a brincar de detetive - um gosto infantil que talvez subjaza a toda arte hermenêutica. José Paulo Paes nos dá lastro para essa reflexão em seu belíssimo ensaio "Para uma pedagogia da metáfora"; parte de uma comparação entre certa consideração de Pascal, a saber, "Figura traz ausência e presença, prazer e desprazer" (apud PAES, 2008, p. 105) entendendo-se "figura" por imagens ou metáforas, e um comportamento infantil anterior à aquisição da fala, o prazer dos pequeninos com o repetido jogo de "esconder" dos adultos, que cobrem o rosto para segundos depois o revelarem, notando em nosso inato "prazer lúdico de perseguir o que tenta fugir" o mesmo prazer com o jogo de "ocultamento e desvelamento" das metáforas - uso de um signo por outro elidindo as relações semânticas entre eles -, e cujo enigma, em um primeiro momento, gera estranhamento/desprazer, pela quebra da continuidade lógica da frase, mas se troca subitamente em prazer quando percebemos as relações lógicas escamoteadas da frase e as restituímos a ela, ganhando uma compreensão agora enriquecida do paradoxo metafórico.

Brinquemos, pois, o conto, em seu ocultamento/desvelamento, partindo, porém, do pedaço de chão que conseguimos pisar. Há, de fato, uma "aventura" que salta do título para a estrutura do enredo. A palavra, etimologicamente "o que advém", "sobrevém", guarda algo de caos e risco, de imprevisibilidade, surpresa, perigos... concordemos que não se planeja uma aventura. E assim temos uma heroína que parte em uma busca, saindo dos domínios socialmente conhecidos para região distante, escolhendo caminhos que a levam a deparar-se com o inesperado, ameaça e perigo, diante dos quais realiza ato heroico, no caso, de salvamento/resgate, para então retornar 
de sua jornada. Eis a estrutura básica da "jornada do herói" como a delineou Joseph Campbell (2007), encontrada seja nos mitos, contos de fadas ou nos romances de aventura. Nosso conto, porém, corresponde e ao mesmo tempo quebra com as imagens típicas dessa estrutura canônica, e um tanto de sua graça/gracejo a isso se deve. Para começar, todas as imagens supostamente "grandiosas" reduzem-se às dimensões infantis da existência. A heroína nada mais é do que uma "menininha, de babar em travesseiro", cuja presença "não dominava 1/1000 do ambiente", de "mão na boca" e "voz menor que uma trova" (ROSA, 1969, p. 174) ${ }^{41}$. A busca em que parte, longe de feito valoroso, conquista de reinos ou tesouros, tem o objetivo prosaico de contemplar um arrozal, ao qual nenhum dos adultos deseja levá-la, e a viagem por "território inexplorado" não ultrapassa alguns metros além do quintal de casa. $\mathrm{O}$ fato ou incidente impressionante, a ação extraordinária que caracteriza o gênero, é o encontro com cena mais do que provável em espaço rural e úmido, uma cobra a devorar um sapo, e o ato heroico é, por sua vez, quase uma paródia da luta com o dragão para resgate da donzela, o salvamento do mesmo "sapo indefeso" quando a menina acerta a cobra com uma "pedrada paleolítica" (p. 176). A busca é, neste momento, interrompida pelos gritos da mãe, que fazem a pequena retornar a casa sem ver os campos de arroz, e o final feliz se ganha e se perde, posto que, em lugar da típica glorificação por seu feito, a heroína recebe zombarias do irmão. Ainda assim... o narrador encerra seu relato dizendo-nos que ela é "dona em mãozinha de chave dourada, entre os gradis de ouro da alegria" (p. 176).

A transposição das altas imagens do enredo heroico a dimensões infantis e tão chãs tem, inevitavelmente, efeito cômico - próximo talvez do riso carnavalesco Bakhtiniano em suas inversões do alto/baixo, grotesco/sublime - para o qual concorrem também as descrições "engraçadas" da protagonista: "[...] inquieta como um nariz de coelhinho. Feliz feito narina que hábil dedo esgravata." (p. 174); " Djá fechava-se sob o instante, careta por laranja azeda"; "Não-me, não!" - Ela repetia, no descer dos cílios, ao narizinho de rebeldias" (p. 175). Algumas, porém, mais evidentemente unem baixo e alto, humor e filosofia, gracejo e beleza/poesia: "Tapava os olhos com três dedos, unhas pintadas de mentirinhas brancas, as faces de furta-flor" (p. 174); "Atirou-lhe uma

\footnotetext{
${ }^{41}$ A partir daqui, todas as referências ao conto "Tresaventura" serão acompanhadas apenas do número da página desta edição.
} 
pedrada paleolítica, veloz como o amor"; "Disse ao irmão, que só zombava: - "Você não é você, e eu queria falar com você" (p. 176).

Veremos ao longo do conto que, para além dos exemplos aqui esboçados, há algo desde o início entretecido na estória que não nos permite resvalar para o riso pura e simplesmente, nem reduzir a narrativa a uma "aventura de proporções infantis" (o mesmo "enredo aventuresco" só se inicia após a metade do conto). Porque a graça como "gracejo" guarda o "dom sobrenatural/mistério" e "atrativo/beleza". A conjunção destes três sentidos parece permear a forma de existência infantil que Rosa coloca diante de nós, divertindo-nos e, ao fazê-lo, desvelando-nos um "supra senso". Como nos lembra o prefácio da obra, quando algo de grande se faz, há um "salto do cômico ao excelso". Este parece ser exatamente o mecanismo que opera no conto e, muitas vezes, na imagem infante rosiana.

\subsection{De sonho e de pó: no miolo da luz, no marrom da terra}

A primeira frase do conto une, de forma elíptica, protagonista e espaço: numa "terra de arroz", da qual se indaga se há, nela, "vestígios de pré-idade", vive uma menina cujos gestos e traços figuram realmente sua (nossa?) pré-idade: "menininha, de babar em travesseiro", "mão na boca", "manhosos olhos de tinta clara", "voz menor que uma trova, os cabelos cacho-cacho" (p. 174). Na graciosa imagem diminuta da criança começa a se delinear para nós um estado infante, numa "anterioridade de ser" que em tudo contrasta com o universo adulto; nossa menina "Ficava no intacto mundo das ideiazinhas ainda" (grifo nosso), furtando-se ao movimento bulhento das pessoas ao seu redor, o "bramido do lar" que a perturba ${ }^{42}$. A outra face da imagem barulhenta e brincalhona comumente associada às crianças é o silêncio, a solidão. Eles aparecem não apenas nos infantes introvertidos - que, veremos, não é o caso de nossa protagonista -, mas talvez porque sejam dimensões constitutivas desse lugar primordial, a origem tanto cósmica quanto humana; do silêncio e solidão viemos, a eles retornaremos. A criança toma parte neles também porque sua existência, sua forma de perceber e se relacionar com o mundo interno e externo, não encontra ressonância no mundo administrado dos adultos. Não foram poucos os autores que ressaltaram, assim, a

\footnotetext{
42 Difícil não lembrar aqui o já citado depoimento do próprio Rosa sobre a infância: "É um tempo de coisas boas, mas sempre com pessoas grandes incomodando a gente, intervindo, estragando os prazeres." (PEREZ, 1991, p. 37)
} 
tendência infantil, em solidão e silêncio, a evadir-se em um "outro mundo", pouco acessível aos demais, feito não sabemos de que tecido, mas de tal luminosidade e delicadeza que o grosseiro universo adulto só lhe pode representar uma afronta.

É prerrogativa dos infantes esse alheamento na imaginação, nos sonhos e devaneios, domínios únicos em que, nos lembra Gaston Bachelard (1988, p. 95), o homem pode experimentar uma irrestrita liberdade. É dito de nossa menina, inclusive, que "Gostava, destriste, de recuar do acordado" (p. 174). Fuga da realidade na imaginação e no sonho? O conto se desenrolará a partir de uma forma da criança olhar o mundo e, mais especificamente, de uma imagem que só ela vê, repudiadas ambas pela atitude realista e objetiva dos adultos à sua volta. Enquanto a lógica hegemônica tende a rechaçar como alienante e improdutiva a entrega ao devaneio, vendo-a invariavelmente como escape ou, no caso dos pequenos, concedendo-a por vê-los ainda aquém do pleno desenvolvimento cognitivo e social, inaptos para a devida relação com a "realidade" ${ }^{43}$, não poucos vislumbraram no devaneio porta para a criatividade, abertura e respiro para sistemas outros de pensamento. Ainda Bachelard: "Quando sonhava em sua solidão, a criança conhecia uma existência sem limites. Seu devaneio não era simplesmente um devaneio de fuga. Era um devaneio de alçar vôo." (1988, p. 94). Veremos se é este o caso de nossa protagonista.

Parece vir deste domínio imaginativo, como dissemos, o desejo pela imagem que moverá toda a aventura: "Antes e antes, queria o arrozal, o grande verde com luz, depois amarelo ondeante, o ar que lá. Um arrozal é sempre belo. Sonhava-o lembrado, de trazer admiração, de admirar amor" (p. 174). À contraposição da criança ao mundo adulto soma-se, aqui, a contraposição do adulto ao mundo da criança, pois, além de não a levarem ao lugar desejado, desconstruíam inteiramente a imagem de beleza e luminosidade por ela sonhada: "[...] longe de casa, terra baixa e molhada, do mato onde árvores se assombram - ralhavam-lhe; e perigos, o brejo em brenha - vento e nada, no ir a ver..." (p. 174). Mas esse "nada" aos olhos adultos é o que existe com mais força para a protagonista. Que arrozal é esse que teria "vestígios de pré-idade", tão insistentemente anelado por nossa pré-menina? Sua descrição é tal - "sonhava-o lembrado" - que não conseguimos afirmar se ela o deseja por já tê-lo visto de fato

\footnotetext{
${ }^{43}$ Às crianças e aos artistas, poetas... porém lembremos com que desdém a sociedade contemporânea ainda olha para a escolha pouco "séria" ou "rentável" desta profissão...
} 
(memória) ou se apenas por imaginá-lo, e ele se suspende entre matéria e ideia, num domínio de beleza quase irreal, além dos dedos corrosivos do tempo, "sempre belo".

Aristóteles ${ }^{44}$, muito antes de Freud, já havia apontado o parentesco entre memória e imaginação, o que serve a prevenir-nos contra a armadilha de darmos estatuto de "realidade" aos frutos da primeira e de "irrealidade" aos da segunda. O psicanalista austríaco, séculos depois, prova como uma lembrança pode ser fruto de uma construção mental, uma ficção (1899); tanto memória quanto imaginação estão, portanto, à mercê do desejo, e este nada mais seria do que um vassalo do princípio do prazer. Em "Dois princípios de funcionamento mental" (1911), Freud aponta os processos mentais inconscientes como os mais antigos, de fato os únicos processos mentais que havia nas primeiras fases de nosso desenvolvimento humano (nossa "préidade"...). Seu propósito [destes processos] seria unicamente buscar tudo o que nos traz satisfação e negar/afastar o que nos causa desprazer/sofrimento. Apenas quando a tentativa de satisfazer os desejos de forma alucinatória falha ${ }^{45}$, a frustração resultante impele o aparelho psíquico a formar uma concepção das circunstâncias reais do mundo - o princípio da realidade - concorrendo para isso também o desenvolvimento de um sistema de notação do observado, a memória. Mas o desejo continua soberano: só estamos empenhados em admitir e registrar a realidade para, a partir desses dados, sermos capazes de nela modificar as circunstâncias que nos desagradam.

A incursão pela psicanálise nos parece válida não só porque a infância seja este primórdio do desenvolvimento humano em que impera ainda o princípio do prazer, mas porque a oposição que já se anunciou no início do conto entre a criança e o adulto pode nos remeter ao princípio do prazer versus princípio da realidade. Os adultos insistem em apor as imagens mais realistas do que seria um arrozal - terra baixa e molhada, sombreada, brejo embrenhado de mato contendo perigos - e as justificativas plausíveis para lá não ir - longe de casa, nada além do vento para se ver. Mas todas as explicações racionais não logram mais do que uma negação do princípio da realidade pela pequena e reafirmação da sua imagem de deleite: "Não dava fé, não o coração [...] o arrozal lindo, por cima do mundo, no miolo da luz. O relembramento" (p. 174).

\footnotetext{
44 "A que parte da alma pertence a memória? É evidente que a esta parte, da qual brota também a imaginação", ele expõe em "Da memória e da Reminiscência", afirmando posteriormente, em seu Tratado sobre a Alma, que "A imaginação não se move sem o desejo". (ARISTÓTELES, apud MENESES, 2004, p. 33)

${ }^{45}$ Segundo Freud, tentamos satisfazer os desejos primeiramente de forma alucinatória, posto não exista, para o bebê, a concepção de sujeito-objeto, portanto, uma "realidade" com a qual operar e um "eu" separado dela.
} 
Trava-se então um diálogo entre nossa menininha, com seu mundo luminoso, pouco realista talvez, e o irmão mais velho, que está "da parte do mundo trabalhoso" (p. 175), plenamente regido pelo princípio da realidade, no qual três imagens, a saber, dos pássaros, da água e dos répteis (cobras/sapos) serão figuradas a partir de visões diametralmente opostas, espécie de tese (irmão) e antítese (menina). Faremos um esquema para que melhor se vislumbrem essas oposições:

Irmão /"mundo trabalhoso"

Tinha de ali agitar os pássaros, mixordiosos, que tudo espevitam, a tremeterse, faziam o demônio. Pior, o vira bosta. Nem se davam do espantalho...

" - A água feia, quente, choca, dá febre, com lodo de meio palmo..."

" - Tem o jararacuçu, a urutu-boi..." - que picavam. O sapo, mansinho de morte, a cobra chupava-o com os olhos, enfeitiço: e bote e nhaque...

A menina / "mundo das ideiazinhas"

Negava ver. Todo negava o espantalho - de amordaçar os passarinhos, que eram só do céu, seus alicercinhos. Rezava aquilo. O passarinho que vem, que vem, para se pousar no ninho, parece que abrevia até o tamanho das asas. Devia de fazer o ninho no bolso velho do espantalho!

Mas, "Não-me, não!" - ela repetia, no descer dos cílios, ao narizinho de rebeldias. Renegava. Reza-e-rezava. A água fria, clara, dada da luz, viva igual a sede da gente. Até o sol nela se refrescava.

Iaí pisquepiscava. Arrenegava. Apagava aquilo: avesso, antojo. Sapos, cobras, rãs eram para ser de enfeite, de paz, sem amalucamentos, do modo são, figuradio. E ria que rezava.

Desdobremos algumas imagens. Enquanto para o irmão os pássaros são vistos como um empecilho na lida da terra, demoníacos em sua desordem, para ela, eles são os alicerces do céu. À imagem escura, quente e lodosa da água, associada à doença, ela confronta sua luminosidade fresca, na simbologia universal que associa a água à vida; e em vez do impulso destrutivo, o bote mortífero da cobra, ela vê nos anfíbios mera 
"figuração" (da paisagem? de seus devaneios?), bichinhos "de enfeite" e "de paz". Temos de notar que, ao lado do princípio do prazer, o que emerge - seja do discurso direto ou do indireto livre pelos quais recebemos a fala e os pensamentos da criança é um olhar inaugural para o mundo carregado de imagens poéticas. Este olhar que nos devolve cena tão prosaica do pouso das aves como se cada momento de sua aproximação do céu ao chão, do voo ao repouso fosse intensamente vivido, visto por fim como um encurtar de asas; que, contrariando a lógica, inverte a utilidade do espantalho, enxergando em seu bolso ótimo lugar de aninhar.

A criança e a poesia se encontram no que ambas têm de "primordiais"; o filósofo napolitano Vico, em sua Ciência Nova (1999), formula a ideia de que a sabedoria poética precedeu a prosa; ela se fazia "não raciocinada e abstrata, como a de agora, dos doutos, mas sentida e imaginada como deve ter sido pelos primeiros homens, pois aqueles desprovidos de qualquer raciocínio, eram dotados de sentidos robustos e vigorosíssimas fantasias" (p. 153-154). Lá, onde a experiência sensória de tal forma nos atinge a ponto de nosso corpo emprestar suas figuras e paixões ao restante dos seres animados ou inanimados; lá, onde a metáfora emerge como premência de expressão para o homem que não apenas vê o mundo, mas "é com o mundo" e faz o mundo "ser com ele", em seus "braços de mar", "riso de águas", "sopro de ventos", lá está também a criança, cuja recente emergência de um estado de indiferenciação primeira entre si e o mundo a dota de capacidades empáticas e metafóricas impressionantes ${ }^{46}$; assim, sua linguagem infante, "anterior à fala" enquanto prosa utilitária, está impregnada de poesia $^{47}$. Para ela, tudo é animado: a luz "dá" a água e nela se "refresca"; tão forte é a percepção sensória do mundo que a própria vida transborda para a sensação de sede e para o elemento água, sobrepondo-se à imagem da morte na corrente expressão "matar a sede": [a água] "viva igual à sede da gente" (p. 175). A "graça" dos infantes está também na sua linguagem, que tanto pode provocar o riso/gracejo, pelas construções inusitadas - sapos, cobras e rãs como "de enfeite, de paz, sem amalucamentos" - como brindar-nos com a beleza poética de suas metáforas. Veremos, mais adiante, ainda outros elementos da poesia a impregnarem a linguagem infante.

\footnotetext{
${ }^{46} \mathrm{O}$ próprio Vico, de resto, toma as crianças por comparação à forma de sabedoria poética desses "primeiros homens": " [...] as coisas admiradas davam o ser da substância de suas próprias ideias, que é, com efeito, a natureza das crianças, que, como se propôs numa dignidade, vemos tomar entre as mãos coisas inanimadas e divertir-se, e conversar, como se fossem, aquelas, pessoas vivas." (p. 154).

${ }^{47}$ Ver a esse respeito também o belíssimo ensaio da prof Adélia Bezerra de Meneses, "Literatura e Psicanálise: aproximações", em Do poder da palavra: ensaios de literatura e psicanálise. São Paulo: Duas Cidades, 2004.
} 
Interessante perceber que, junto da afirmação das imagens poéticas e luminosas, o movimento de "negação" do discurso do irmão pela menininha vai crescendo morfologicamente: negava, renegava, arrenegava. Ao lado dele, porém, outra imagem foi também sorrateiramente se desdobrando em progressão: rezava, reza-e-rezava, $e$ ria que rezava. A reza, relação com o sagrado, o mistério, já fora anunciada no início do conto, e vai sendo entretecida à dimensão da existência desta menininha, ampliandoa para além do devaneio e do imperativo do princípio do prazer. Resgatemos as primeiras descrições de nossa protagonista.

Quem é ela? "A menina", o conto a identifica de início, num artigo definido que, acompanhando substantivo genérico, pouco especifica, para em seguida dizer que os adultos "só a tratavam por Djá ou Iaí", nenhum deles, claramente, nome próprio. É ela mesma, quem, mais do que se nomear, "de ser, se inventava: Maria Euzinha" (p. 174). Nova contraposição: à ausência de nome com que os adultos a tratam, a invenção do próprio ser. Sabemos que não era incomum as crianças muito pequenas permanecerem por um tempo sem nome próprio, não reconhecidas como "pessoas de fato" nem mesmo pelos pais ${ }^{48}$; e quem morou em Minas Gerais sabe que é possível passar uma vida inteira chamando alguém por seu apelido sem jamais saber-lhe o nome. Mas os apelidos aparentemente sem senso trazem uma ressonância familiar: Djá ecoa "já", o instante presente; Iaí, o dêitico "aí", "neste lugar". Juntos, podem bem figurar o hic et nunc, "aqui-agora", atualidade temporal e espacial absoluta em que vivemos nos primórdios de nossa existência e que, por mais que tentemos, dificilmente logramos alcançar novamente ${ }^{49}$. Um "tempo fora do tempo", que escapa à horizontalidade da percepção cronológica para verticalizar o vivido, sendo, segundo Piaget ${ }^{50}$, apenas uma duração interna. Mas "Iaí" pode também soar como "E, aí..." expressão afim a "E, então...", por sinal muito usada pelas crianças como conectivo em suas narrativas, e que marca prenúncio de acontecimento em um tempo passado. Djá/Iaí: aqui/agora ou

\footnotetext{
${ }^{48}$ Phillipe Arriés, em seu História social da criança e da família, explora o progressivo reconhecimento que a criança vai ganhando ao longo do século XII até o XVIII. Ressaltemos, aqui, apenas a passagem "Se ela morresse, como muitas vezes acontecia, alguns podiam até ficar desolados, mas a regra geral era não fazer muito caso, pois outra criança logo a substituiria. A criança não chegava a sair de uma espécie de anonimato" (1981, p. 10, grifos nossos)

${ }^{49}$ No capítulo 1 exploramos essa condição de extrema atualidade dos infantes, lembrando "Menino a bico de pena", de Clarice Lispector, como lapidar exemplo; ainda outra frase do mesmo conto: "Lá está ele, um ponto no infinito. Ninguém conhecerá o hoje dele. Nem ele próprio. Quanto a mim, olho e é inútil: não consigo entender coisa apenas atual, totalmente atual. (1996, p. 64).

${ }^{50}$ Ideia desenvolvida no capítulo 1 deste trabalho, no sub item 1.2 Psicanálise e filosofia: pistas sobre o existir infante.
} 
presente/passado. Guardemos estas imagens. "Maria" seria nome de batismo? Não sabemos, mas a ele a protagonista acopla signo máximo da afirmação de si dentro da língua portuguesa, criando como nome quase um superlativo de identidade que, não obstante, está no diminutivo e, ao que parece, é usado somente por ela: Maria Euzinha. "A menina", "Djá", "Iaí", "Maria Euzinha", uma proliferação de nomeações resvala inevitavelmente para um esfumaçamento de definição, com signos que se desdobram de apelidos vazios para identificações polissêmicas, e o último, ápice de afirmação identitária, mas no diminutivo, aparentemente não usado pelo coletivo.

"Cada um de nós ainda não é o que "é", tem de esforçar-se por chegar a ser" (ROSA, 2003, p. 258). Esta é certamente a primeira e última aventura humana, em que todos nos empenhamos. Nossa "menininha de babar em travesseiro" terá também, como toda criança, de se haver com esta alta tarefa, emergindo da não existência para a existência, da pura subjetivação para a relação com o outro, o "intacto mundo das ideiazinhas" chocando-se com o "movimento em torno" e o "mundo trabalhoso" dos adultos. Seu diálogo com o irmão, inclusive, nos remete à "crise de oposição" ${ }^{51}$, cujo apogeu situa-se em idade compatível com a que dela imaginamos, por volta dos três anos, quando a necessidade de afirmação de si (vide o nome que ela se deu) e de independência (parte sozinha para sua aventura) desperta diversos tipos de rivalidade em relação aos mais velhos. "Cautela, todavia" 52: o infante é desenhado, aqui, na ambiguidade daquele que "ainda não é" e, ao mesmo tempo, "é por demais". Ao lapidar questionamento shakespeareano a literatura de Rosa invariavelmente responde com o paradoxo: "ser e não ser". Maria Euzinha, sem nome e com muitos, pequena, aquém da lógica do universo adulto, mergulhada em "ideiazinhas", suspira por algo que não $s a b e^{53}$, e logo o narrador lhe atribui um saber muito próprio: "Sabia rezar entusiasmada e recordar o que valia. A abelha é que é filha do mel. Os segredos a guardavam" (p. 174). Seus dois saberes, rezar e recordar, apontam, o primeiro, para uma dupla relação espiritual com o mundo, rezar entusiasmada (etimologicamente, en + théos $=$ "com Deus dentro") e o segundo, para uma capacidade de re-cordar (do latim cordis,

\footnotetext{
${ }^{51}$ Em A psicologia da Criança, Piaget, ao analisar as interações sociais e afetivas quando do advento da representação semiótica pelas crianças, diz que dela "[...] resulta uma série de novidades, cujo apogeu principia cerca dos 3 anos com o que Ch. Büler denominou crise de oposição, assinalada pela necessidade de afirmação e independência, assim como por todos os gêneros de rivalidades, de tipo edipiano ou, de modo geral, em relação aos mais velhos [...]" (1999, p. 98-99)

${ }^{52}$ Assim alertou Antonio Candido a seus leitores quanto à ilusão de que a geografia de Grande Sertão: Veredas se esgotaria na observação dos mapas brasileiros. (1991, p. 296)

53 " - Eu não sei o quê... suspirinhos." (p. 174). Afirmar um não saber é, socraticamente, atitude dos sábios.
} 
coração), repor no coração aquilo que "valia". O que seria? A formulação elíptica da frase não diz, só apresenta em seguida duas imagens que trazem uma inversão, da lógica de causa e efeito a primeira, já que o mel é que seria "filho" da abelha, e da lógica sintática e semântica a segunda, posto sermos sempre nós a guardarmos os segredos.

Além, contudo, da inversão lógica, ser "guardada por segredos" é viver rodeada pelo mistério, custodiada e protegida por ele, por aquilo que não devassamos, apenas vislumbramos. Essa mescla de "ser" e "não ser" na identificação da protagonista revela, ao lado da visada psicanalítica de desenvolvimento humano, um dos aspectos que a imagem da criança congrega desde os mitos mais antigos. Karl Kerényi, em seus estudos sobre o mito da Criança Primordial, assim define seu estado: "being not yet separated from not-being, yet still being"54 (1949, p. 94). A criança está próxima a uma dimensão original que não abarcamos; ela apenas ingressou no mundo a partir de "lá" 55 , o insondável de onde viemos e para onde retornaremos... quem poderá dizer com o que ela dialoga em seus silêncios, sua solitude? Nesta visão mítica ou metafísica, sua existência não se resume a equacionar princípio do prazer e da realidade, mas guarda, na relação com o entorno, a natureza, a linguagem, o outro, algo deste estado de "nãoser", anterior ao mundo tal qual o conhecemos, na supremacia de suas leis naturais, de seus códigos linguísticos e sociais, do imperativo racional, o que permite-lhe justamente uma "forma outra de ser". Nossa Maria Euzinha, que "rezava entusiasmada", comunga ainda com essa dimensão do mistério, e às imagens do que é objetivamente o mundo para o irmão, os pássaros, a água, os anfíbios, ela poeticamente reza outras, marcadas principalmente pela beleza, luminosidade e bondade. Assim, ao lado da "graça" delicada, poética ou mesmo cômica de que se revestem os pequeninos, a menina participa também da graça enquanto "dom sobrenatural", relação com o mistério. $\mathrm{O}$ encontro entre ato criativo, brincadeira e religiosidade, no seu sentido propriamente etimológico de re-ligare, permeia a própria escrita rosiana, conforme Paulo Rónai tão bem ressaltou ao afirmar que, para Rosa, " [...] escrever tinha tanto de brincar quanto de rezar" 56 .

O próprio narrador não descarta como devaneio vão a imagem luminosa do arrozal negada pelos adultos, antes a atribui a uma sabedoria. De Dja/Iaí, ele diz que

\footnotetext{
54 "Não estando ainda separado da não-existência, contudo já existindo" (tradução nossa)

${ }^{55}$ Essa mesma dimensão do "lá" será desdobrada, com outras nuances, no próximo capítulo, enfocando aquela que é mais propriamente, na literatura rosiana, "A menina de lá".

56 "Os Prefácios de Tutaméia", O Estado de São Paulo, 16 de março de 1968.
} 
"Não dava fé, não o coração. Segredava-se, da caixeta de uma sabedoria: o arrozal lindo, por cima do mundo, no miolo da luz. O relembramento." (grifos nossos) e, pouco adiante, que ela "Não cedia desse desejo, de quem-me-dera. Opunha o de cor de si, fervor sem miudeio, contra tintim de tintim." (grifos nossos). "Segredo", "sabedoria" e "coração" se encontram. Podemos não saber ao certo se a imagem do arrozal é memória ou imaginação, mas ela é sabida com o coração, e para preservar este "de cor de si", Djá/Iaí fervorosamente se opõe a tintim de tintim do que lhe for racionalmente explicado. Nesta "tresaventura" podemos ver também algo dos heróis ditos românticos, que não abdicam do impulso do sentimento mesmo quando confrontados com o princípio da realidade ou a voz da razão, e que se aventuram por aquilo que, para os demais, não passa de devaneio, sonho ou loucura. Talvez porque eles saibam de algo que os outros não sabem... O infante, em seu estado originário e original, está também mais próximo deste outro saber, fareja coisas para além da razão, do objetivamente percebido; coisas que estão "por cima do mundo", "no miolo da luz", que só os capazes de "rezar entusiasmados" vislumbram.

A grande força desta figuração infantil, porém, não está numa rejeição ao princípio da realidade, ao mundo objetivo; diferente dos loucos/alienados, que rompem com a lógica causal e as leis naturais e sociais, e dos adultos que rechaçam as dimensões imaginativas, poéticas ou metafísicas da existência, a criança rosiana aparece como a que está entre mundos, e por isso os conjuga. Ela quer existir no mundo sensível, experimentá-lo sensorialmente, ver, tocar, cheirar, relacionar-se com o outro, sair do anonimato e indiferenciação dos meros apelidos para fazer-se sujeito, Maria Euzinha, sem deixar de trazer consigo o imperativo do prazer, o amor admirativo pela beleza, pelos bichos e elementos da natureza, a relação com a imaginação, o devaneio, o mistério, a palavra poética, sua sabedoria de "verdades outras" que desafiam a realidade sensível em suas leis. Assim é que, voltando ao fio do enredo, o diálogo que lá atrás deixamos entre Dja/Iaí e seu irmão mais velho, no qual armou-se um jogo dialético das teses deste com as antíteses daquela, "rezadas" a partir de um "de cor de si", terá sua síntese no plano da experiência infantil, e a protagonista, "inquietinha, dada à doença de crescer", sai do intacto mundo das ideiazinhas para o mundo bem concreto, de terra e água, em busca de seu arrozal; e tudo condensado magistralmente na frase que traz a passagem do anseio enquanto projeção mental, no tempo futuro, para sua realização no presente: "Hei-de, hei-de, que vou!" - agora mesmo e logo, enquanto o gato se lambia." (p. 175). E a aventura começa. 
Apontamos, no início, como neste momento do enredo as imagens da jornada do herói em dimensões infantis é em parte responsável pela "graça" em seu aspecto cômico no conto; a ele estará sobreposta também sua face "graciosa", na beleza das construções poéticas que continuarão se desdobrando quando a lente narrativa, nas fronteiras do discurso indireto livre, cola-se à percepção da criança que observa o mundo. As referências infantis que filtram seu sentimento e a imagem do céu são metáforas poéticas: "Saíra o dia, a lápis vermelho - pipocas de liberdade", e todas as descrições do que é visto no quintal são carregadas de aliterações, assonâncias, rimas, personificações e descrições inusitadas, tão próprias de uma linguagem infante, anterior à fala normativa, como vimos, claramente partícipe da fala poética:

\footnotetext{
"Sus, passou a grande abóbora amarela [assonância do "a"], os sisudos porcos, os cajus, nus [assonância de o/u e aliteração do "s", além da personificação dos animais e da fruta], o pato do bico chato, o pato com a peninha no pico [rima e imagem "graciosa" do bichinho, sublinhada pelo diminutivo], a flor que parecia flor, outras flores que para cima pulavam, as plantas idiotas, o cão, seus dislates [descrições inusitadas - comparar uma coisa com ela mesma; personificação das flores - pulavam - e das plantas, com adjetivo insólito que não deixa de ser "engraçado" - idiotas; uso plástico da linguagem no neologismo final"]. (p. 174)
}

O narrador então, mesmo fora do discurso indireto livre, deixa impregnar sua linguagem de formas infantis, repetições e diminutivos, bem como do criativoinusitado de certos vocábulos para graciosamente descrever a pequena frágil que, não obstante, se faz heroína voluntariosa em sua busca: "Virou para um lado, para o outro, para o outro - lépida, indecisa, decisa. Tomou direitidão. Vinha um vento vividinho, ela era mimo adejo de ir com intento" (p. 175). A partir deste momento em que ela escolhe uma direção, todas as imagens prenunciadas no diálogo com o irmão - os pássaros, a água, a cobra e o sapo - serão encontradas pelo caminho, e a descrição que temos da vivência da criança não figura nem a realidade puramente objetiva nem a imagem ideal que ela de início postulava, mas uma síntese, podemos pensar, entre princípio do prazer e princípio da realidade, visão pragmática e olhar poético, conhecimento objetivo e sabedoria do coração. 
Os pássaros não estão cantando. Como o irmão, encontram-se empenhados na lida da terra, "trabalhavam catando o de comer, não tinham folga para festejo" (p. 175). Ainda assim, seu silêncio atribuído a "astúcia e arte" suscita no discurso indireto livre do narrador a pergunta de Dja/Iaí: "Fingiam que não a abençoavam?", abrindo com a interrogação uma brecha na realidade objetiva: mesmo em seu aspecto mais terreno, pragmático, a ausência de bênçãos, de comunhão pelo mistério, é apenas aparente. Em vez de "só do céu, seus alicercinhos", os pássaros, como a menina, conjugam os dois mundos, na lida da subsistência que, para o sentir de Dja/Iaí, continua contendo o dom da bênção celeste. $\mathrm{O}$ encontro com a água é um êxtase, em toda intensidade exclamativa de alegria e surpresa infantis com cena outrossim tão prosaica: "E eis que a água! A poça de água cor de doce-de-leite, grossa, suja, mas nela seu rosto limpo límpido se formava. A água era a mãe-d'água" (p. 176). Sua realidade "grossa e suja", que seria de repulsa, se transfigura no doce delicioso e (re)vela, na aparente opacidade, o dom especular de devolver à menina sua imagem "limpa límpida". Em uma mesma frase juntam-se, ainda, a realidade concreta, objetiva "a água" e a simbólica, subjetiva, "a mãe d'água" ${ }^{57}$.

O enredo de aventura então prenuncia sua reviravolta: "Aqui, o caminho revira - no chão, florinhas em frol - dali a estrada vê a montanha"58 (grifo nosso), e no próprio nome da protagonista, "Iaí" = "E, aí..." podemos ler a expressão narrativa que marca o suspense prévio a anunciar o clímax, que se dá no terceiro e decisivo encontro:

"Iaí pegou do ar um chamado: de ninguém, mais veloz que uma voz, ziguezagues de pensamento. Olhou para trás, não-sei-porquê, à indominada surpresa, de pôr prontos olhos. O mal-assombro! Uma cobra, grande, com um sapo na boca, estrebuchado... os dois marrons, da cor da terra." (p. 176)

Longe do "enfeite, de paz", do "modo são, figuradio", em que nossa protagonista concebia os sapos, cobras e rãs, o encontro é com a realidade mais terrena ("marrons, da cor da terra") em suas leis inexoráveis da cadeia alimentar. Mas ele se

\footnotetext{
${ }^{57}$ É do campo do simbólico o pensamento que plasma, a partir da beleza e perigo que as águas encerram, a figura da sereia, sedutora e fatal, que nas lendas amazônicas recebe o nome de Iara ou "Mãe d'água". A mesma dicotomia impregna, a partir desta imagem benéfica/maléfica, a incursão aventuresca de Djá/Iaí.

${ }^{58}$ Não deixemos de notar, ainda na esteira da percepção poética da criança, a personificação da estrada que vê a montanha.
} 
deu por instâncias misteriosas, por uma via de comunicação que não a palavra-matéria, mas uma palavra-ideia, "mais veloz que uma voz, ziguezagues de pensamento", na forma de um "chamado" que, sem qualquer explicação racional, a faz olhar para trás. Confrontada a imagem ideal com a crua realidade que o irmão já lhe havia esboçado, a síntese se dará, e a protagonista imediatamente (Djá = já) substitui seu movimento de negação do diálogo anterior pelo de ação no mundo: "Djá tornou sobre si, de trabuz, por pau ou pedra, cuspiu na cobra. Atirou-lhe uma pedrada paleolítica, veloz como o amor." (p. 176).

É uma ação movida pelas forças do coração, o "de cor de si", o princípio mais antigo do mundo, "paleolítico"... A cosmogênese grega concebe Eros como um dos deuses primordiais, anterior aos titãs e olímpicos, e jamais retratado como adulto, sempre menino ou jovem imberbe. A criança, em sua existência original, estaria, também, mais próxima dele? Todo ato heroico é, afinal, uma ato de amor; com ele, Djá não abdica de sua capacidade de "recordar o que valia", seja ela a possibilidade de inversão lógica ou seu saber secreto afim à percepção poética do mundo, nem nega a realidade, mas a opera, como já afirmara Freud, para fazer prevalecer seu desejo, interrompendo o curso das leis naturais; e essa ruptura, tanto da cadeia lógica de eventos quanto da cadeia alimentar, é marcada nas próprias estruturas morfológicas do texto, recuperando-se uma grafia em desuso, ab-rupto, que frisa a ruptura no próprio corpo da palavra, e nos dois neologismos criados a partir do prefixo des-, de carga semântica negativa: "Aquilo desconcebeu-se. O círculo ab-rupto, o deslance". E a cobra larga o sapo e foge, "lefe-lefe-lhepte, como mais as boas cobras fazem", deixando-o "só com pouquinho pontinho de sangue, sobrevivo" (p. 176). Além da reposição da imagem ideal de bondade da cobra, da onomatopeia e do uso de diminutivo tipicamente infantis, a pergunta feita em seguida, a expressão "hão-de" ${ }^{\text {"59 }}$ e a ideia da reza reafirmam ser pela lente da própria protagonista que nos chega todo este trecho narrativo: "O sapo tinha pedido socorro? Sapos rezam também - por força, hão-de! O sapo rezara" (p. 176).

Desde a misteriosa comunicação intuitiva, passando pela inexorabilidade das leis naturais e sua ruptura, o ato de heroísmo de enfrentamento da "cobra-dragão" e resgate do "sapo-donzela-indefeso" e a imagem de comunicação do reino animal com o humano como um ato de fé, de re-ligação com o mistério, poderíamos ter síntese mais acabada entre princípio do prazer e princípio de realidade, dimensões físicas e

\footnotetext{
${ }^{59}$ Já usada pela protagonista em seu "Hei-de, hei-de, que vou!".
} 
metafísicas, imagens cômicas, grotescas e sublimes? De fato, após essa passagem se dá a única ocorrência de síntese do nome da protagonista: "Djaiaí, sustou-se e palpou-se só a violência do coração bater. A mãe, de lá gritando, brava ralhava. Volveu. Travestia o garbo tímido, já de perninhas para casa" (p. 176). Em nosso enredo aventuresco, o "retorno do herói" é também tingido de certa "graça", graciosa e engraçada, subvertendo a tradição dos contos de fadas: após vencer bravamente a cobra-dragão, submeter-se, obediente e tímida, aos gritos da mãe... de perninhas para casa.

\subsection{Neblinuvens... a bela coisa!}

E o arrozal? "Não chegara a ver", nos diz o narrador. É bem verdade que, em certos enredos de aventura, o herói parte com determinado objetivo apenas para descobrir que a "realização heroica" que lhe cabe é outra, dada pela imprevisibilidade das circunstâncias. O motivo do acaso, das forças ocultas que movem o destino dos homens paralelamente a seus desígnios e desejos é recorrente na obra rosiana ${ }^{60}$, e não deixaria de agregar sentido à "tresaventura" de Maria Euzinha, que pensava ir ao encontro do lugar luminoso sonhado, de qualidades celestes, quando, na verdade, estava indo ao encontro da descoberta do mundo, com bichos, plantas, água e lama, inclusive com a iminência da morte. Algo a mais, encoberto, para além do que lhe era dado conhecer (a "reza" por socorro do sapo?) tecia-se paralelamente ao seu desejo de sair "agora mesmo e logo", para com ela se encontrar a meio caminho.

Há, porém, outro "algo a mais"...

Se compararmos as descrições da imagem do arrozal, duas já citadas e a terceira ao final do conto, à epígrafe, certas recorrências nos saltam aos olhos:

"Antes e antes, queria o arrozal, o grande verde com luz, depois amarelo ondeante, o ar que lá. Um arrozal é sempre belo. Sonhava-o lembrado, de trazer admiração, de admirar amor."

\footnotetext{
${ }^{60}$ Lembremos, entre outros, o conto "Sequência", de Primeiras Estórias, em que um rapaz parte em obstinada perseguição para trazer de volta uma vaquinha fujona e ao final descobre que, na verdade, estava indo ao encontro do amor. Ou mesmo o "Recado do Morro", de Corpo de Baile, em que, na contramão da viagem do protagonista Pedro Orósio, vai viajando um recado, tecido de muitas vozes, e que é, de fato, mensagem cifrada de seu próprio destino.
} 
"Segredava-se, da caixeta de uma sabedoria: O arrozal lindo, por cima do mundo, no miolo da luz - o relembramento"

"E o arrozal não chegara a ver, lugar tão vistoso: neblinuvens. - "A bela coisa!" - mais e mais se disse, de devoção, maiormente instruída."

"... no não perdido,

no além passado... (MNEMÔNICUM $)^{61}$

Os trechos em negrito apontam, todos, para uma "anterioridade", algo que está "antes" e que é (re)lembrado. Os trechos em itálico reforçam a luminosidade e a beleza deste "algo" e aqueles sublinhados apontam para sua qualidade imaterial, etérea, não visível, que o coloca em outra instância, "por cima" do mundo. Já falamos da criança em seu aspecto mítico como aquela próxima à origem, lugar-mistério de onde viemos e para onde retornamos, que traz para sua experiência do mundo algo dessa existência "alhures" ${ }^{62}$. Se tomarmos todas estas imagens juntas, aliadas à indagação sobre os "vestígios de pré-idade" daquela terra de arroz e à declaração do narrador de que nossa Maria Euzinha ficava "no intacto mundo das ideiazinhas ainda", não podemos deixar de perceber forte ressonância com o "mundo inteligível" platônico, transcendente, com suas formas luminosas, belas, incorruptíveis ("um arrozal é sempre belo"), oposto ao mundo imanente, de cópias materiais imperfeitas.

Ao lado dele, nos ressoa a também platônica teoria da reminiscência ${ }^{63}$, abordada em três diálogos, Mênon, Fédon e Fedro, cada um dando-nos a ver dela facetas diversas. Em Mênon parte-se da ideia reencarnacionista de Píndaro segundo a qual a alma, sendo imortal, ao longo de inúmeras reencarnações já viu tudo o que há neste

\footnotetext{
${ }^{61}$ Não encontramos nenhum autor ou obra com o nome que consta dessa epígrafe. Imaginamos, portanto, que ela possa ser mais uma pista-jogo de Rosa a compor os sentidos do conto. "Mnemonicus", do latim, "relativo à memória", tem por genitivo "mnemonicum", ou seja "da memória".

${ }^{62}$ Silvia de Ambrosis Pinheiro Machado, participando de uma de nossas oficinas literárias com o tema da infância em Rosa, chamou a atenção ao trecho "o ar que lá", em que ressoa também o termo "arché", princípio, origem, matriz.

${ }^{63}$ Muitos são os estudos que apontam a analogia entre o pensamento platônico e a literatura rosiana sendo que o próprio autor se confessa alinhado a ele em carta a seu tradutor italiano (Rosa, 2003, p. 90). Mas nos interessa especialmente aqui o estudo de Suzy F. Sperber, Caos e Cosmos (1976), no qual, analisando as leituras de Platão feitas por Guimarães Rosa a partir de seus exemplares anotados, ressalta que "Os principais conceitos platônicos assinalados por Rosa, aparentemente, referem-se ao mito da caverna, ao conceito do amor que, decaído, perde suas asas, e à crença na alma antes do nascimento e depois da morte" (p. 65). Todos conceitos que concorrem para nossa análise.
} 
mundo e no Hades, por isso quando aprende/conhece algo, está, na verdade, apenas recuperando, relembrando o já visto/conhecido. Daí que "ciência/saber" equivaleria a "reminiscência" (PLATÃO, 2001, p. 51-53). Esta mesma ideia é desenvolvida em Fédon (PLATÃO, 1979) para ressaltar que esse conhecimento prévio ao nascimento engloba os "conceitos em si", as realidades essenciais do mundo inteligível, o "bom em si", o "belo em si", que perdemos por ocasião do nascimento. Os amantes do conhecimento sentem que a alma encarcerada, ligada ao corpo, é obrigada a perceber a realidade como se através de barras de prisões, e não as realidades "por si mesmas"64; para recuperá-las, há que afastar-se dos sentidos e concentrar-se apenas na alma, pois somente ela vê o invisível, apreendido pela inteligência. E em Fedro, a imagem da "alma alada", que se eleva aos domínios luminosos, "região acima dos céus" ${ }^{65}$, participando do divino que é "belo, sábio e bom" (p. 219), vislumbrando as "Verdades Eternas" (PLATÃO, 1954, p. 222) do mundo inteligível, mas que, "devido a um desvio funesto, se enche de alimento impuro, de vício e de esquecimento, torna-se pesada e precipita-se sem asas ao solo", ${ }^{66}$ é exposta por Sócrates para explicar a quarta espécie de delírio de que o homem pode ser presa, que se dá "[...] quando alguém neste mundo vê beleza. Recorda-se, então, da beleza verdadeira; recebe asas e deseja voar para o alto; não o podendo, porém, dirige o olhar para cima esquecendo os negócios terrenos e dando, desta maneira, a impressão de delirante"; o filósofo termina dizendo que quem é atingido por este delírio "ama o que é belo e chama-se amante." ${ }^{67}$ (p. 222)

Longe de explicar o mistério do conto por uma teoria platônica, queremos que seus pontos de ressonância, bem como os de dissonância, o ampliem, desdobrando camadas de sentido do enredo e da vivência infante de nossa protagonista. $\mathrm{O}$ par ciência/reminiscência reaparece quando "da caixeta de uma sabedoria" Maria Euzinha tira o "relembramento" de seu arrozal, recordação daquilo que, malgrado o "esquecimento" da existência terrena, permanece "no não-perdido", memória de alma do lugar de onde viemos e para onde retornaremos, "além passado". É uma criança pequenina a que detém esta sabedoria/lembrança... ela, que em seu pouco tempo de

\footnotetext{
64 "... o corpo constituia para a alma uma espécie de prisão, através da qual ela devia forçosamente encarar as realidades, ao invés de fazê-lo por seus próprios meios e através de si mesma" (p. 88)

${ }^{65}$ Vale a pena ver o trecho completo: "Nenhum poeta ainda cantou nem cantará a região que se situa acima dos céus" (p. 220)

${ }^{66}$ Todo este trecho do diálogo sustenta-se claramente na teoria reencarnacionista elaborada por Píndaro, já citada em Mênon.

${ }^{67} \mathrm{O}$ discurso socrático procede desenvolvendo, a partir da teoria da reminisção, o elogio do amor Erótico como delírio a partir da visão do belo, o que encontrará ecos na visão do belo arrozal por Maria Euzinha.
} 
existência terrena, está menos esquecida das instâncias metafísicas de onde acabou de ingressar. Que sua imagem de arrozal tinha contornos mais ideais do que reais era claro, mas a insistência em localizá-la "por cima do mundo, no miolo da luz", de uma beleza, como já vimos, que não fenece, "sempre belo", também nos remete aos "conceitos em si", formas puras, sabidas como reais, mas que, quando buscadas neste plano, não logramos encontrar ${ }^{68}$. Essa inversão que toma o visível por "irreal" e o invisível/ideal, por "real", não estaria no jogo "não ver"/"vistoso", cujo último termo guarda o duplo sentido de visão e de beleza: "E o arrozal não chegara a ver, lugar tão vistoso neblinuvens - "A bela coisa!" (p. 176)? Não só o substantivo "neblinuvens", mas a expressão com que a protagonista se refere ao arrozal tira dele seu contorno sensível, de lugar definido; ao lado do substantivo indefinido "coisa", o adjetivo "bela" ganha preponderância e emerge para nós absoluto... quase uma figuração do "belo em si".

Visão e beleza ainda se relacionam, platonicamente, com um "delírio amoroso", que também encontra eco no conto. Como na exposição socrática, o delírio com a beleza luminosa do arrozal, relembramento de nossa Maria Euzinha, é menosprezado pelos demais, mas ela, que sabia "recordar o que valia", "dirige o olhar para cima esquecendo os negócios terrenos" (PLATÃO, 1954, p. 222.), o "mundo trabalhoso" e o "movimento em torno, gente e perturbação", para voltar à imagem seus olhos, seu anseio amoroso: "Sonhava-o lembrado, de trazer admiração, de admirar amor" (p. 174); "Sempre a ver, rever em ideia o arrozal" (p. 175, grifos nossos). Neste mesmo discurso, Sócrates diz que a visão é o mais sutil de todos os sentidos e que a beleza "brilhava entre todas aquelas Ideias Puras e na nossa estada na terra ela ainda ofusca, com seu brilho, todas as outras coisas" (p. 223). Porém, se dizemos que Maria Euzinha "esquece os negócios terrenos", é apenas à lida dos adultos, com sua visão pragmática, que nos referimos; longe do ideal platônico de distanciar-se do mundo sensível para, apenas pela contemplação da alma, atingir a Verdade, ela quer, neste mundo de terra e água, com suas plantas e bichos, encontrar seu arrozal sonhado, e para isso parte.

\footnotetext{
${ }^{68}$ Em outro conto do mesmo livro, "Lá, nas campinas" (1969), o protagonista Drijimiro também está às voltas com a recuperação de um lugar dos primórdios de sua existência, "no nenhum lugar antigamente" (p. 84) igualmente feito de água e claridade, vegetação e pássaros, ainda que dele esteja já bem mais esquecido do que nossa Maria Euzinha, restando-lhe apenas frase narrativa, "Lá, nas campinas". E também ele, quando tenta encontrá-lo fisicamente, depara-se apenas com o mundo sensível, em frase que atribui caráter de inexistência, fragilidade e utopia à realidade: "Nada encontrava, a não ser o real: coisas que vacilam, por utopiedade.", em contraste com a imagem perene incorruptível, trazida da anterioridade da existência e recuperada em seu final, o "além passado" da morte: "Tudo era esquecimento, menos o coração. - Lá, nas campinas!..." - um morro de todo limite. O sol da manhã sendo o mesmo da tarde." (p. 87)
} 
As imagens que nos movem, nossos anseios sem fundo continuam, na literatura rosiana, tocados pelo mistério. Quer o arrozal de Maria Euzinha tivesse de fato sido visto na terra e nela suscitado a lembrança de beleza outra, luminosa e perene, quer tenha sido a memória/imaginação a forjá-lo a partir do mistério insondável que antecede e prossegue à nossa existência, "não perdido e além passado", o coração parece saber que há algo para além do que os sentidos podem apreender e do que o tempo pode corromper. É possível que, psicanaliticamente, o associemos à nostalgia das primeiras vivências psíquicas de indiferenciação, ou de um narcisismo primário, porém não tê-lo encontrado no plano concreto não anulou a relação da criança com seu relembramento, antes, após dele exclamar "A bela coisa!", o narrador nos conta que ela "mais e mais se disse, de devoção, maiormente instruída", e estende para sua relação com o irmão a percepção de que só somos mais puramente "nós mesmos" quando abarcamos também essa dimensão outra da existência, mas "perdemos nosso ser" quando, confiados apenas no pragmatismo, menosprezamo-la: "Disse ao irmão, que só zombava: "-Você não é você, e eu queria falar com você." (p. 176).

A graça do infante rosiano, na figura de Maria Euzinha, emerge quando o centro de gravidade do mistério da existência se desloca das instâncias puramente inteligíveis/sobrenaturais para o ponto de encontro entre o visível e o invisível, o físico e o metafísico, o micro e o macro, o cômico e o excelso. O viés psicanalítico e o metafísico aqui não se anulam, antes tingem o mistério da existência infantil de múltiplas e ambíguas dimensões. DjaIaí, a criança na graça de seu aqui/agora absoluto que nos escapa, no imperativo do prazer delirante com a imagem ansiada para além de todo princípio de realidade, é também DjaIaí na graça de seu presente/passado, se havendo com as contingências atuais da matéria, porém guardando uma relação com a origem, o sagrado, o mistério, segredos e rezas, o relembramento de lugar belo e luminoso aquém e além deste mundo, que igualmente não logramos abarcar.

Por isso sua "graça" é feita de uma existência em que coincidem o humor, a beleza e o sublime. Maria Euzinha, infante "ainda não separada da não-existência, contudo já existindo" (KERÉNIY, 1949, p. 94), guardada por segredos e incursionando pelo mundo, ao final de sua tresaventura, adormece, "dona em mãozinha de chave dourada, entre os gradis de ouro da alegria". Enquanto a visada platônica carrega de puro negativismo a imagem da alma encarcerada no corpo a perceber a realidade como por entre grades de prisão, para a criança que conjuga os dois mundos e com eles se deleita, seus gradis, sejam os concretos, de seu berço, sejam os metafóricos, da 
existência terrena com seu princípio de realidade, são de ouro e de alegria, e ela lhes detém a chave.

\subsection{Hermenêutica e Aletria... fios sem arremate}

Nos preâmbulos desta análise apontamos que toda hermenêutica guarda, em si, uma atitude lúdica, um jogo detetivesco de desvendar por detrás de uma coisa outra coisa, havendo que ser, para afrontá-la, um pouco criança e querer brincar. Nos domínios literários, como nos lembra José Paulo Paes, nosso prazer do jogo é com as palavras, e a primeira do conto ainda nos resta: Tresaventura.

Podemos conceber "tres-" em sua qualidade expletiva, intensificadora, encontrada em "tresloucado", "tresdisse", e que venha, talvez, do próprio número "três", usado tantas vezes como fórmula de repetição nas narrativas orais, desde a épica grega passando pelos contos de fadas, para enfatizar determinada ação. Assim teríamos uma "grande aventura"; a grande aventura infantil de sair do mundo das ideiazinhas para o mundo concreto e nele descobrir-se sujeito, capaz de transformar a realidade, sem, contudo, perder o deleite e as dimensões poética e metafísica de sua relação com o mundo - aliás, ser capaz de transformá-lo justamente por não tê-los perdido, caído em conformismo. O número "três" aparece ainda nos três encontros do caminho, prenunciados no diálogo: pássaros, água e cobra/sapo, que remetem a três elementos primordiais, ar, água e terra. Ele é, não nos esqueçamos, o número da síntese dialética, que nos tira do binarismo estanque - tese/antítese - ao colocá-lo em movimento. Se somarmos a essa imagem a carga semântica de "através" contida nesse prefixo, revelada em "trespassar", por exemplo, teremos como título "através da aventura"; como através dela nossa Dja/Iaí chegou à síntese das realidades físicas e metafísicas, do presente e dos primórdios, do pragmatismo e da poesia, culminada por uma "pedrada paleolítica, veloz como o amor" que lhe deu a síntese de seu próprio nome e, quem sabe, a chave dourada dos gradis da alegria.

Um conto em que os muitos nomes da protagonista admitem diversos sentidos, em que uma imagem ideal nos suspende entre imaginação ou reminiscência, em que o mistério, o insondável, tem de ser admitido como operador da realidade tanto quanto suas leis físicas e a graça vai unindo os fios de seus três sentidos, vislumbramos que a "graça" de toda literatura é ser, ela própria, uma grande metáfora do mundo. Se, ainda platonicamente, concebe-se que o particular só existe na medida em que participa do 
universal, a literatura é, justamente, aquela que revela o universal no particular ${ }^{69}$. Aqui, ela vela no pequeno, no insignificante, por vezes gracioso ou engraçado, um suprasenso ancorado na beleza, no dom/mistério e nos coloca diante da experiência de que o sensível contém, em si, sentidos outros por desvelar. Nesta imagem igualmente platônica em que o mundo como o conhecemos - a própria vida - seria composto por signos/imagens a velar uma outra coisa, a "sobre coisa", o "quem das coisas"70, é que a literatura, para ser vida ${ }^{71}$, reproduz o mesmo jogo, velando em sua linguagem, seus "hieroglifos", sua massa visível de letras - aletria-, o invisível, impalpável, mistério da totalidade, "mea omnia", por interpretar - hermenêutica.

A brincadeira permanece. Enquanto nós, porém, diante do conto, tomamos o caminho analítico da exegese, extraindo dele nosso comprazimento lúdico em desvelar o oculto, a criança rosiana está mergulhada nessa existência metafórica e metafísica, existe na e pela linguagem poética, sabe o mundo a partir do coração e da reminisção, é guardada por segredos sem ter de explicá-los; sua alegria está não em "abrir a porta" mas em ser, ela mesma, a chave do mistério.

\footnotetext{
${ }^{69}$ José Paulo Paes, no ensaio já aqui referido, aponta que é desta capacidade da poesia de revelar o universal no particular que advém seu "valor heurístico de redescoberta do mundo: para além da realidade factual, ela nos leva até uma outra, a do possível. Pergunta-se Paul Ricoeur se "não é função da poesia sucitar um outro mundo, - um mundo que corresponda a possibilidades outras de existir, a possibilidades que sejam os nossos possíveis mais próprios?" (2008, p. 125). O existir infantil poeticamente figurado por Rosa em sua Maria Euzinha não nos leva a esta "redescoberta do mundo", suscitando-nos, igualmente, possibilidade outra de existir, quiçá nosso "possível mais próprio"?

${ }^{70} \mathrm{~A}$ "sobre-coisa" era o que queria o compadre Quelemém dos relatos de Riobaldo, em vez do "caso inteirado em si" (2001 p. 214), e o "quem das coisas" (a própria poesia?) era o que o patrão do Grivo, Cara-de-Bronze, o mandou buscar em viagem pelo Sertão (1978, p. 101).

${ }^{71}$ Assim a queria Rosa: "Legítima literatura deve ser vida. Não há nada mais terrível do que uma literatura de papel, pois acredito que a literatura só pode nascer da vida [...]" (LORENZ, 1991, p. 84)
} 


\section{Capítulo 3. "A menina de..."}

\subsection{Lá: entre a infância e a desrazão}

Os desajustados, anormais, excluídos, se já ganharam o palco literário na Idade Média, muitas vezes roubaram definitivamente a cena na literatura moderna e contemporânea. $\mathrm{O}$ olhar para o que é marginal, que passa ao largo da cultura e do pensamento hegemônico a propor formas outras de existência, está no centro da literatura rosiana, e assim é com o infante. Há alguns elementos que se tocam entre loucura e infância; qualquer adulto que adotasse comportamentos ou mesmo traços de linguagem infantis poderia bem ser relegado ao ror dos "doidos", "dementes".

Certo é que a sociedade parece ter sempre consentido aos pequenos a prerrogativa da "desrazão", dando-a por condescendência àqueles cujo aprendizado do mundo, em suas normas socioculturais de conduta e comunicação, está ainda incompleto, ou mesmo o desenvolvimento cognitivo, em seus complexos processos de análise e abstração, é ainda incipiente. Palavras que diminuem, construindo o sujeito infante novamente no signo da falta, da carência e, nessa negatividade apenas, parecem apaziguar-se os "normais" diante da forma de existência perturbadoramente diversa das crianças.

É curioso que Rosa, autor que mantinha correspondências intensas com seus tradutores e colegas, de teor profundamente erudito, tenha se dedicado com não menos interesse e entusiasmo literário ao diálogo com uma criança cujo pensamento ainda estava, como ele mesmo diria, em "fase hieroglífica". Trata-se de publicação epistolar até hoje olhada mais com curiosidade biográfica do que interesse crítico - inclusive assim vislumbrada por dois grandes intelectuais amigos do autor que a prefaciaram; Ooó do vovô é compilado das correspondências que Guimarães Rosa trocou, ao longo de mais de um ano (de setembro de 1966 a novembro de 1967), com suas netas "de coração", Vera e Beatriz Helena Tess, netas biológicas de sua segunda mulher, Aracy. A via é praticamente de mão única, visto sua principal interlocutora, Vera Tess, ter à época entre 3 e 4 anos. Dissemos "interesse e entusiasmo literário" porque o que transparece na redação das cartas não é apenas a motivação afetiva, mas verdadeiro anseio comunicativo plasmado em fino trato com as palavras e imagens, na exploração do universo infantil em sua identidade linguística móvel, híbrida, oral, impregnada das 
marcas sintáticas e morfológicas típicas da interlocutora de 3 aninhos - "Vovô atí, Titia atí, Nenem vem atí?" (2003, p. 16) - mesclada a desenhos com legendas, colagens, e uma porção de interferências gráficas, letras em caixa alta, a escolha da disposição das palavras no papel, pontos de exclamação, reticências...

Esse olhar que eleva o trato linguístico-comunicativo com a criança à mesma importância do diálogo intelectual adulto é revelador do "mundo misturado" 72 de Rosa, que chama ao interesse literário todas as dimensões da existência, principalmente aquelas consideradas "menores", "falhas", "incipientes", para convertê-las em princípio de composição. Porque quando a falta revela-se potência, o mundo é obrigado a recomeçar; assim nosso autor reinaugura a existência e a linguagem, em sua "falta" de normas linguísticas - ortográficas, sintáticas, morfológicas -, em sua "carência" de delimitação precisa dos gêneros literários, em sua "incipiente" racionalidade narrativa, que franqueia ao mágico o domínio do plausível; e que, irmanado aos infantes no que é "carência" segundo a norma, tem em suas personagens pequeninas potente chave de subversão do olhar razoável dos adultos - personagens, sim, mas também nós, leitores.

Nesta mesma troca epistolar, em carta não a Verinha, mas à sua irmã pouco mais velha, vovô Joãozinho lista uma série de estórias que vai contar às meninas, dentre elas, a "estória da menina chamada Nhinhinha" (2003, p. 60), personagem de "A menina de lá", conto então já publicado em Primeiras Estórias. Resta-nos apenas imaginar como seria a versão oral, contada de boca, pelo avô a suas pequenas! Mas não deixa de ser curioso que Nhinhinha, como Verinha, tivesse seus "nem quatro anos", e igualmente dirigisse seu afeto a um interlocutor adulto, afeito à arte de contar: o próprio narrador.

Trata-se, aqui, novamente, de uma tenra infância. Nhinhinha, ao lado de Dja/Iaí, suas idades presumivelmente muito próximas, é uma das menorzinhas protagonistas rosianas; com ela, o signo da falta, do pequeno, reatualiza o princípio da reversibilidade ${ }^{73}$ para tensionar, agora, os limites entre normalidade e anormalidade, razão e desrazão, realidade e magia; infante ainda mais atípica, ela beira a loucura/desrazão ao lançar-nos ao limiar mais extremo entre conhecido e desconhecido, existindo em um lugar do qual apenas nos aproximamos, mas que não logramos, de

\footnotetext{
${ }^{72}$ Expressão cunhada por Davi Arrigucci Jr. a partir de fala do Jagunço Riobaldo, em Grande Sertão: Veredas, e que dá título ao ensaio no qual o crítico explora as misturas constitutivas do romance instrinsecamente relacionadas ao mundo misturado do protagonista, conforme já mencionamos no Capítulo 1 (Op. Cit, 1994 pp 7-29).

${ }_{73}^{73}$ Destacado por Antonio Candido como princípio fundamental da obra rosiana e já explorado no Capítulo 1 do presente trabalho. (Op. Cit., 1983, 305)
} 
fato, alcançar; entre a inquietação e a simpatia, somos ainda assim levados a descortinar, nas frinchas da falta, domínios de insondável plenitude que, quiçá, não pertença mesmo a "este mundo".

Há uma distinção importante, já estabelecida por alguns pensadores, entre "loucura" e "desrazão". Peter Pál Pelbart, dialogando com Blanchot, Foucault e Deleuze, resume-nos tais linhas distintivas ${ }^{74}$. A noção de loucura, que certamente não é uma invariante histórica, está na "relação do homem a seus fantasmas, a seu impossível, à sua dor sem corpo, à sua carcaça de noite" (1993, p. 93); ela é essa "Exterioridade Enigmática", que Foucault denominou "o exterior, o fora", na qual o sujeito mergulha até o ponto de nela dissolver-se; a loucura é, portanto, ruína do Ser, da Identidade, do Sujeito, porque se trata de uma exposição "sem proteção alguma à violência desse Fora" e, assim, sem condições de estabelecer uma relação de ida e volta entre ele e a realidade objetiva. Já a "desrazão" seria uma relação com essa exterioridade, que se dá, sim, na órbita de uma ruptura com a lógica hegemônica, a "normalidade", sob o signo do acaso, da ruína, da força ou do desconhecido, mas que não implica em dissolução do sujeito. Foucault chamou de Pensamento do Exterior o pensamento que se expõe ao Fora mantendo com ele essa relação de troca, de trânsito, de aventura. Tal forma de pensamento foi, segundo ele, explorada por diversos autores, Blanchot, Holderlin, Nietzsche, que fizeram ecoar as vozes da desrazão.

Guimarães Rosa parece estar entre eles. Que prefira a desrazão à "megera cartesiana" é coisa que fez questão de confessar a seu tradutor italiano:

Ora, Você já notou, decerto, que, como eu, os meus livros, em essência, são "anti-intelectuais" - defendem o altíssimo primado da intuição, da revelação, da inspiração sobre o bruxolear presunçoso da inteligência reflexiva, da razão, a megera cartesiana. Quero ficar com o Tao, com os Vedas e os Upanixades, com os Evangelistas e São Paulo, com Platão, com Plotino, com Bergson, com Berdiaeff - com Cristo, principalmente. (2003, p. 90)

\footnotetext{
${ }^{74}$ Devo à disciplina "Loucura, desrazão e normalidade: leitura de textos de Literatura Brasileira", ministrada pelas Profas Dras Belinda Mandelbaum e Yudith Rosenbaum na pós graduação de Letras da USP, em 2018, a incursão por este vasto território. O potente ensaio "Guimarães Rosa e o canto da desrazão" (ROSENBAUM, 2008, pp. 150-158) inspirou o percurso desta análise, ao partir da distinção desses dois territórios psíquicos, loucura e desrazão, para contemplá-los na interface com a arte em três contos rosianos, "Sorôco, sua mãe, sua filha", "A menina de lá" e "A terceira margem do rio".
} 
Proclamando o "altíssimo primado da intuição" sobre a razão, filiando-se a místicos e filósofos, expõe-nos invariavelmente em suas narrativas a experiências da ordem do aberto, do impossível, do inominável. Para tal, vale-se do que o crítico Antonio Candido nomeou super-regionalismo em sua obra, um aproveitamento do que era substância do nativismo, do exotismo, do pitoresco-regional, nutrida de "elementos não realistas, como o absurdo, a magia das situações." (2000, p. 161-162). Como já apontamos em citação anterior, Rosa mesmo, indagado sobre os aspectos realistas/regionalistas de sua obra, alertou "[...] quanto mais estou apoiando, quanto mais realista sou, você desconfie. Aí é que está o degrau para a ascensão, o trampolim para o salto" (CAMACHO, 1978, p. 47).

Todos os infantes, de alguma forma, portanto, transitam pelos domínios da desrazão. "A menina de lá", porém, dá o salto, e nos mostra o que seria habitá-lo de fato, até o último limiar. O enredo do conto se faz simples: em um lugarejo isolado do sertão brasileiro, uma menina de "nem quatro anos", que intriga os pais, a tia e o próprio narrador com uma linguagem e comportamento incomuns, começa a operar milagres, concretizando pela fala seus pensamentos e desejos... até o momento em que diz a própria morte e se vai. O elemento mágico se infiltra na narrativa: o impossível, o feito tão somente divino, cuja potência é de tal ordem que inaugurou o mundo - Deus disse: "Faça-se a luz", e a luz se fez-, será realizado por uma menininha mal entrada em idade de articulação do pensamento racional, em ponto remoto no sertão. "Lá" é o lugar inominável, a experiência da desrazão diante da qual o conto nos coloca a partir de um estado de existência que contraria a lógica racional, a normalidade, e ao qual somos conduzidos pela figura do infante, o pequeno, aquele a quem ainda falta - a fala, a cognição, a aculturação -, mas, por isso mesmo, atesta-nos o "altíssimo primado da intuição" sobre a razão. Se é válida a correlação semântica saber/sabor, procuremos "saber" o conto como consumia a protagonista seu pratinho de comida: com "artística lentidão".

"A menina de lá". "Lá", onde? É a primeira provocação ao leitor, que desde o título foi obrigado a habitar um vazio, na expectativa de que o conto o preenchesse. Acontece que "lá" é, por si só, um impossível linguístico. É um locativo, o que vale dizer localiza-nos uma realidade espacial concreta, apontável ainda que distante... mas que resvala inevitavelmente em indefinição, só sanável por substantivo de que se faça acompanhar: "Menina, vai lá na cozinha buscar um copo d’água!"; "Ah, Minas? Sim, 
já estive lá". Assim, avulso, "lá" exige-nos de pronto uma disponibilidade para a incognição, porque lança-nos ao aberto. Está armado o jogo, em que pode-se dar por certa a expectativa e tentativa do leitor, em seus procedimentos racionais, de encontrar uma definição para o indefinido.

Uma única vez o "lá" será referido no conto, pela própria criança-protagonista, que diz "Quero ir para lá", ao que seu interlocutor adulto, atônito, indaga, "Aonde?", cabendo-lhe como resposta tão somente a confirmação do incognoscível: "Não sei" (ROSA, 2001, p. 69) ${ }^{75}$. "Lá" jamais será nomeado. Ele será o ponto do qual se desdobrarão imagens do que é Exterior ao homem, o Fora, aquilo a que, na feliz imagem que nos dá Pelbart, a história já emprestou diversas formas: "Caos do Mundo, Aventura da Linguagem, Estranheza da Natureza, Transcendência do Divino, Fúria da Morte, Sagrado dos Elementos, Bestialidade do Humano etc." (1993, p. 95) mas que, malgrado nossos esforços de linguagem, permanece da ordem do inominável. $O$ narrador, não obstante, é ardiloso, e às primeiras linhas nos entrega uma sequência descritiva de espaço ao qual seria bastante tentador referir o locativo: "Sua casa ficava para trás da Serra do Mim, no meio de um brejo de água limpa, lugar chamado o Temorde-Deus" (p. 67). Lá terá nascido e vivido Nhinhinha, cujo nome de batismo é Maria. Ainda nos é dito que o "Pai, pequeno sitiante, lidava com vacas e arroz", enquanto a "Mãe, urucuiana, nunca tirava o terço da mão" (p. 67). A referência, contudo, é apenas aparentemente concreta; tão logo nos detemos nos signos, ela se desmancha no ar: "para trás da serra do mim"; "o Temor-de-Deus". Temos nítida impressão de que "alguém de tudo faz frincha para rir-se da gente" ${ }^{16}$ nesse jogo de significantes e significados pouco realistas dos topônimos, prenunciando uma anterioridade e uma religiosidade... que por ora ficarão em suspenso, mas que guardaremos como dois âmbitos do "lá" tocados pelo texto.

\subsection{Fazendo vácuos... a estranha graça.}

\footnotetext{
${ }^{75}$ A partir daqui, todas as citações do conto "A menina de lá" virão acompanhadas apenas da referência ao número da página.

${ }^{76}$ Frase do conto "O espelho", do mesmo Primeiras Estórias, em que o narrador vislumbra o fracasso da racionalidade humana diante do transcendente: "Ah, meu amigo, a espécie humana peleja para impor ao latejante mundo um pouco de rotina e lógica, mas algo ou alguém de tudo faz frincha para rir-se da gente..." (2001, p. 120-121).
} 
Há uma voz que nos narra. Em um primeiro momento, parece tratar-se de narrador onisciente, porém a certo ponto ele se nos revela observador que conheceu de fato a protagonista, por quem ela teve empatia. O leitor conforta-se na legitimidade do discurso enquanto testemunho daquele que conhece, presenciou. Mas a segurança dura pouco... seremos obrigados, ainda uma vez, a habitar vazios: nada mais dele sabemos. Seria um parente distante? Um conhecido da família? Um viajante de passagem? Seu contato parece ter sido breve e pontual. A primeira parte de seu relato, em que comparece inclusive um momento de diálogo entre ele e a menina, termina abruptamente com a frase "Nunca mais vi Nhinhinha" (p. 69). Mas até essa afirmação, a quase metade do conto, o narrador nada mais fez a não ser se empenhar em construir para nós a imagem da protagonista.

Há um halo de "graça" invariavelmente conferido por Rosa a seus pequenos, nos múltiplos sentidos de "gracejo", "gracioso"/"belo" e "dom sobrenatural", já explorados no capítulo precedente, que se aplicam também aqui. Nhinhinha tem expressões engraçadas, "Ele xurugou?", e comportamentos que fazem rir, como chamar o pai por "Menino pidão"; outros são mesmo de singeleza graciosa, seu dedinho apontando para o céu, suas estórias curtas, pequeninas como ela mesma; quase redundante apontar o "dom sobrenatural" na graça milagrosa que ela opera com as palavras. Essa graça vem, no entanto, imbuída de alguma estranheza, um riso forçosamente oblíquo... porque a imagem que o narrador faz surgir diante de nós é essencialmente da ordem do estranho, construída nos signos da negatividade, do que se "subtrai" à norma.

Nhinhinha tem na própria identidade a marca do diminutivo, reforçada pela primeira descrição que dela faz o narrador: "Ela, menininha, por nome Maria, Nhinhinha dita, nascera já muito para miúda, cabeçudota, e com olhos enormes" (p. 67, grifos nossos). Não bastasse o apequenamento constitutivo, a sequência descritiva dos próximos três parágrafos é permeada de negativas. Nhinhinha será, para nós, à medida que não é: "Não que parecesse olhar ou enxergar de propósito"; "não queria bruxas de pano, brinquedo nenhum"; "pouco se mexia"; "ninguém entende muita coisa que ela fala"; "com seus nem quatro anos"; "não incomodava ninguém e não se fazia notada, a não ser pela perfeita calma, imobilidade e silêncios"; "nem parecia gostar ou desgostar especialmente de coisa ou pessoa nenhuma"; "Nada a intimidava"; "Não se importava com os acontecimentos" (p. 67-68, grifos nossos). 
A ausência, o vazio, o silêncio, a imobilidade. Para uma sociedade cuja norma se fez a atividade, a fala, o dinamismo, a velocidade, Nhinhinha só pode causar estranhamento. Mais ainda considerando que seu desenvolvimento psicofísico parece aquém em aspectos significativos da relação do sujeito com o mundo na esteira dos estudos de desenvolvimento das crianças: o movimento (andar), a comunicação (falar) e o interesse/vontade (querer/desejar) ${ }^{77}$. Não ignoramos que em certas tipologias das personalidades distinguem-se já bem precocemente os introvertidos/contemplativos dos extrovertidos/ativos - o próprio Guimarães Rosa, relembrando sua infância, não tem dificuldade em se colocar entre os da primeira categoria, afirmando que ainda havia de "escrever um tratado de brinquedos para meninos quietos." (PEREZ, 1991, p. 38). Vemos, porém, que a menina de lá escapa à mera categorização normativa de introvertida, tensionando os limites de suas ausências.

Nhinhinha existe numa imobilidade quase absoluta, seja de gestos, seja de deslocamento: "... sempre sentadinha onde se achasse, pouco se mexia"; "não se fazia notada, a não ser pela perfeita calma, imobilidade e silêncios" (p. 67-68). À ausência de movimento externo soma-se a ausência de vontades/desejos esperados das crianças. Aqui, bastaria invocar o suplício que assola a hora das refeições para tantos pais, que parece especialmente escolhida pelos pequenos para afirmar sua autonomia e poder de negação, em flagrante contraste com a cena de Nhinhinha e seu pratinho de folha no colo: "Botavam para ela a comida, ela continuava sentada [...] comia logo a carne ou o ovo, os torresmos, o do que fosse mais gostoso e atraente, e ia consumindo depois o resto, feijão, angu, ou arroz, abóbora, com artística lentidão" (p. 68). Seu desejo tampouco se volta para a tipicamente cobiçada boneca de pano ou outros brinquedos. O silêncio predomina sobre a fala, ela "fazia vácuos". Quando esta aparece, é também desviada da norma, seja pela "estranhez das palavras", inventadas, ininteligíveis - "Ele xurugou?" -, seja pelo "esquisito do juízo ou enfeitado do sentido", como em "Tatu não vê a lua..." (p. 67). A comunicação utilitária é praticamente inexistente; Nhinhinha sai de seu silêncio apenas para "referir estórias, absurdas, vagas, tudo muito curto", ou para repetir seu refrão de radical desprendimento, confundível mesmo com letargo ou apatia: "Deixa... Deixa...".

\footnotetext{
${ }^{77}$ Vide os conceitos de estágio sensório-motor e pré-operatório de Jean Piaget, em $O$ nascimento da inteligência na criança (1970), e as teorias antroposóficas de desenvolvimento infantil, que dão especial atenção ao "pensar", "sentir" e "querer", em Bernard Lievegoed, Desvendando o crescimento - As fases evolutivas da infância e da adolescência (1994).
} 
Somam-se a essas ausências a da incorporação das normas sociais. Ela é aparentemente incapaz de assimilar qualquer noção hierárquica; rebaixa pai e mãe a seus iguais, chamando-os "Menino pidão" e "Menina grande", provocando-lhes a zanga, diante da qual o narrador sublinha uma não menos surpreendente ausência de medo da criança em relação ao adulto, que culmina na inversão dos papéis - e, com ela, na da relação de "inferioridade" e "superioridade" entre pais e filhos: "Mas, o respeito que tinha por Mãe e Pai, parecia mais uma engraçada espécie de tolerância" (p. 68).

Diante de tal forma de existência, os adultos - nosso narrador, inclusive -, terão invariavelmente duas reações: "Ninguém entende muita coisa que ela fala..." - dizia o Pai, com certo espanto."; "De vê-la tão perpétua e imperturbada, a gente se assustava de repente" (p. 68, grifos nossos). Arremedando o espanto e o susto, o narrador se questiona sobre o que parece ter sido pensamento já proferido por outros: "Seria mesmo seu tanto tolinha"? A debilidade mental, ausência de juízo, é aventada como explicação para aquilo que se desvia da norma, e afinal, é certo que muitas crianças subnutridas do sertão sofrem a deformação física (a cabeça enorme e o corpo mirrado de Nhinhinha) aliada à deficiência cognitiva. A pobreza circundante, o contexto social de isolamento e carência sutilmente anunciados na descrição do espaço, com a casa no meio de um brejo, e na ocupação paterna de pequeno sitiante, esboçam realidade regional que daria lastro a tal explicação.

A narrativa rosiana, porém, jamais se faz unívoca, e o seu realismo está antes na ambiguidade constitutiva do mundo, nas inversões e misturas, do que na lógica de binômios excludentes: "O senhor ache e não ache. Tudo é e não é." (ROSA, 2001, p. 27), anuncia Riobaldo, narrador de Grande Sertão: Veredas, a seu ouvinte assisado e instruído. Assim é que as imagens que visitamos nessa primeira parte do conto, anterior ainda ao advento do elemento mágico-miraculoso, comportam todas uma ambiguidade radicada na Coincidência dos Opostos: demência/sabedoria; imobilidade/mobilidade, silêncio/verbo criador; carência/plenitude. Desdobremos essas imagens.

Nhinhinha, antes de ser Nhinhinha, é Maria. Nome comum, nos sertões de nosso Brasil; nome de santa, da santa, Maria, Mãe de Deus; a que foi a um só tempo pertencente à terra - mulher, esposa de José, mãe de Jesus - e ao céu - santa, virgem, mãe do Cristo. Nhinhinha também está entre a Terra - o pai, sitiante, cujo trabalho é associado à agricultura (arroz) e pecuária (vacas) - e o Céu - a mãe, urucuiana, cujo terço é conexão celeste perpétua, mesmo em meio às obrigações da matéria. A dimensão arquetípica que a maiúscula lhes empresta - "o Pai", "a Mãe" - ajuda a 
corroborar tais imagens. E vemos que Nhinhinha tem sua vivência terrena profundamente atravessada pelo celeste. Em um primeiro momento, seu principal interesse volta-se para a comunhão com os astros, o ar, o alto, a luz: "Ela apreciava o casacão da noite. - 'Cheiinhas!' - olhava as estrelas, deléveis, sobre humanas"; "... Altura de urubu não ir. O dedinho chegava quase no céu"; "A gente não vê quando o vento se acaba..." (p. 69).

O que poderia parecer carência de vontade e apatia, do ponto de vista do desenvolvimento da personalidade, ou mesmo predomínio de pulsão de morte, segundo a psicanálise, é em Nhinhinha plena pulsão de vida se a olharmos em um ethos cuja lógica escapa ao apego material, à relação utilitária com o mundo e às prerrogativas de comportamento que nos dariam o almejado pertencimento social. Ethos que tem pontos de contato com a existência infante, mas que, por outro lado, dela se descola: enquanto os pequenos se deleitam com tudo o que é lúdico e querem pertencer, participar socialmente do ambiente que os circunda, Nhinhinha recusa brinquedos, bonecas de pano, "acontecimentos" do mundo que entusiasmam os demais; mas extrai um prazer intenso da contemplação admirativa da natureza - o tatu, a lua, as estrelas, os pássaros, o arco-íris... "Tudo nascendo!" é a sua "expressão dileta", prenhe de profunda percepção da vida enquanto processo de renovação constante, o mundo movente, não estagnado, que para as crianças é sempre novo, sempre outro... Nela temos o infante enquanto o que está "antes da fala" normativa, da língua enquanto sistema fechado, mas em sua plena potência de uma "fala outra", adâmica, inaugural, de eficácia poética, que une a experiência sensorial do mundo à experiência inaugural da linguagem: tudo nascendo, e por isso, a língua nascendo para dar conta do vivido, mesmo que fora dos códigos linguísticos socialmente partilhados. "Ele xurugou?" - não sabemos quem ou o quê, mas aí está, sem dúvida alguma, um significante criado para um significado genuinamente sentido pela protagonista. Nós a estranhamos, talvez, pela tão radical e tranquila recusa a entrar no jogo sociocultural ao qual os demais infantes também se dobram, mas o "estranhamento", já alertou Freud, emerge de experiências há muito familiares, apenas esquecidas ou recalcadas; a supremacia das vivências subjetivas, abertura a percepções do movimento da natureza em sua dimensão genesíaca, a relação admirativa com o mundo e criativa com a linguagem é um lugar infante que todos, em dado momento, já habitamos. Nhinhinha, apenas, nele permaneceu, no extremo limiar do envolvimento com o mundo objetivo-sensível que não deixa de partilhar com seu interlocutor; o faz, porém, a partir de um "lá", lugar outro da existência e da linguagem. 
Um dos fortes aspectos desse lugar "desarrazoado" de Nhinhinha, mas que é, este sim, traço partilhado por quase todos os infantes, rosianos ou não, é uma relação com o indefinível, o aberto, a disposição plena para o "móvel mundo" ${ }^{78}$, a vida enquanto criação e recriação contínua: "Tudo nascendo!". Em caderno inédito do autor, lê-se trecho já citado em nossa introdução que merece ser retomado no presente contexto:

Até as coisas, em si, mudam a cada instante (digo em si, porque, quanto ao sistema de inter-relações cósmicas, todas as noções deviam ser revistas, quase cada dia: jogada a primeira bomba atômica, até a noção de rabo de boi e do capim teriam que se transformar no Chapadão do Urucuia ou no Pantanal do Mato Grosso). Viver é uma operação mágica. Por isso, também, porque a vida recomeça a cada minuto, é indispensável a gente se fazer como menino, ser como criança - "Amen dico vobis, nisi conversi fueritis, et efficiamini sicut parvuli, non intrabitis in regnum coelorum" (SPERBER, 1982, p. $78)^{79}$

A existência infante de Nhinhinha ancora-se, assim, no sentimento pleno de ser no mundo, de estar existindo; sua imobilidade externa é, ao mesmo tempo, mobilidade interna, existencial... Sua ação não tem objeto nem objetivo; ao "fazer" utilitário dos adultos, invariavelmente acompanhado de velocidade dinâmica, ela contrapõe o "ser", tranquilo, calmo, mas imbuído de movimento continuo, de uma qualidade de eternidade posto seja sem parada, nascendo sempre, apoiado textualmente no prolongamento das vogais que perduram e no gerúndio que coloca a ação em processo: "De vê-la tão perpétua e imperturbada, a gente se assustava de repente. - 'Nhinhinha, que é que você está fazendo?' - perguntava-se. E ela respondia, alongada, sorrida, moduladamente: 'Eu... to-u...fa-a-zendo'"' (p. 68). E porque ancorada no ser, ressoando em sua existência a constante mobilidade que está inexoravelmente para além das estruturas linguísticas e sociais criadas pelo homem na tentativa de ganhar sobre o fluxo cambiante da vida algum controle, é que Nhinhinha profere seu "Deixa... Deixa...", como quem se entrega

\footnotetext{
${ }^{78}$ Expressão a que já nos referimos no primeiro capítulo, extraída do conto "As margens da alegria", cujo protagonista, o Menino, arquétipo da infância, se verá às voltas com a incessante transformação de si e do mundo.

79 "Em verdade vos digo: se não vos transformardes e vos tornardes como criancinhas, não entrareis no reino dos céus."
} 
de corpo leve a boiar nas águas fortes de um rio ${ }^{80}$. "Suasibilíssima, inábil como uma flor"; A aliteração do "s" nos leva a deslizar com ela no fluxo da existência, na "inabilidade" para o afã de fazer, que é habilidade para o afã de existir, "como uma flor".

Sua incapacidade de assimilação da ordem hierárquica social, apesar de nos inquietar, faz conter na debilidade uma superioridade, explicitada na imagem graciosamente cômica da pequenina de gestos e discursos pouco articulados, mas cujo estado de existência é de tal forma pleno, distante do utilitarismo atarefado dos adultos constrangidos pela ordem social e material, que a leva a olhá-los com complacência; aos pais resta serem meramente "tolerados", não "respeitados". Em uma das imagens em que volta seu olhar para um bicho da terra, o tatu, é para reconhecê-lo como o que não vê o celeste, luminoso: "Tatu não vê a lua" (Seremos nós o tatu, soterrados em nossos anseios, constrangidos à matéria, ao fazer, cavando buracos e preenchendo-os de ruídos, inaptos para a lua...?) Nova reversibilidade, em que o comportamento dito normal, razoável, se define no signo da negatividade, da falta.

Superemos a humilhação de nos reconhecermos tatu e continuemos... Nhinhinha habita um "lá" infante aquém dos laços de aculturação que nos constrangem, da lógica utilitária do mundo, do afã por fazer, do anseio por poder ou controle, entregue à vida enquanto processo fluido e à linguagem enquanto manifestação da contemplação que nasce do silêncio; e o que aos poucos emerge de tal forma de existência é da ordem da plenitude na carência: um estado de liberdade e alegria. Livre porque não é presa da lógica dominante que rege os anseios, desejos, medos e apegos dos que a circundam: "Ninguém tinha real poder sobre ela, não se sabiam suas preferências." (p. 68).

\section{3 "Senhora Vizinha": no limiar da terceira margem}

Um "lá" concretamente chamado "O Temor-de-Deus" é existencialmente habitado por Nhinhinha em preceitos por demais afins aos dos santos de variadas religiões. Os seus vazios constitutivos, silêncio, imobilidade, contemplação, seu ser não sendo, levam-na à liberdade e alegria, da mesma forma que Buda afirmou o apego - à matéria, aos desejos - como fonte de todo sofrimento e, portanto, o desapego como

\footnotetext{
${ }^{80}$ Nhinhinha é aqui parente de nosso burrinho Sete de Ouros, único que, por "ir sem afã, à voga surda, amigo da água", se salva na enchente do rio cruzado pelos vaqueiros, no conto "O burrinho pedrês" em Sagarana (1978, p. 65).
} 
único caminho de libertação e felicidade. Analogamente, o hinduísmo vê o apego do homem ao corpo físico, com seus cinco sentidos dos quais derivam preferências e aversões, como princípio da grande ilusão humana que o aprisiona, impedindo-o de realizar o estado de bem-aventurança em que supera as dualidades da matéria e se experimenta como alma unida ao Espírito. E o grande mestre do cristianismo, interrogado por Pilatos, responde: "Meu reino não é deste mundo" (Jo, 18:36). O reino de Nhinhinha tampouco, ela que quer ir "para lá"; a aproximação a esses preceitos religiosos prenuncia no conto a mudança súbita do enredo, em que à imagem da "criança tolinha" se somará a de "santa". Historicamente, houve sempre linha tênue entre santidade, sabedoria e loucura. São Paulo - com quem, aliás, Rosa já nos disse se alinhar, na Carta ao Coríntios pronunciou: "Falo na condição de louco, e o sou mais que ninguém", em trecho que Michel Foucault, na sua História da loucura na Idade Clássica, transcreve para apontar que "Loucura é esta renúncia ao mundo; loucura, o abandono total à vontade obscura de Deus; loucura, esta procura cujo fim não se conhece" (1978, p. 32). Não se parece demais à forma de existência de nossa Nhinhinha, que renuncia aos objetos de desejo das crianças, às preferências e aversões - "nem parecia gostar ou desgostar especialmente de coisa ou pessoa nenhuma" -, que se abandona a uma vontade que não a sua, no fluir da vida, com seu "Deixa... deixa..."?; e que, veremos, também tem uma "procura", um anseio, "cujo fim não se conhece"?

Tanto os loucos quanto os santos/sábios partilham também da alegria. Esta é disseminada em frases que pontuam praticamente todos os momentos em que Nhinhinha sai do silêncio para a palavra: "Com riso imprevisto: - 'Tatu não vê a lua...' - ela falasse"; "E ela respondia, alongada, sorrida, moduladamente: - 'Eu... to-u...faa-zendo'; "... e comentava, se sorrindo: - 'Menino pidão... Menino pidão...'; "'Tudo nascendo!' - essa sua exclamação dileta, em muitas ocasiões, com o deferir de um sorriso"; "E ela riu: - 'Está trabalhando um feitiço...'; "Sorria, apenas, segredando seu - 'Deixa... Deixa...'; "'Deixa... Deixa...' - se sorria, repousada, chegou a fechar os olhos..." (grifos nossos).

É o sorriso de quem sabe algo... de quem guarda um segredo; ponto limítrofe entre a loucura e a sabedoria, pois é o sorriso de quem vislumbra o mundo a partir de outro lugar de existência... "lá"? Nele, as imagens da ordem da desrazão que já apontamos serão acrescidas de tonalidades metafísicas. Pouco antes do advento do miraculoso, algo na conversa do narrador com Nhinhinha nos prenunciou associação do "lá" com o "lado de lá" da vida. No parágrafo em que ele reproduz o diálogo, 
encontramos as seguintes passagens: "'Eu quero ir para lá.' - Aonde? - 'não sei'."; "Eeu? Tou fazendo saudade."; "Outra hora, falava-se de parentes já mortos, ela riu: 'Vou visitar eles..."' (p. 69). A querência por um "lá" desconhecido, reforçada na imagem de "fazer saudade", culmina na alegria com a ideia de visitar os parentes mortos. A "procura cujo fim não se conhece" aponta aqui para uma realidade metafísica, que supera as dimensões da matéria mas que, curiosamente, na percepção de Nhinhinha, não está dela separada, não se configura como reino outro que implique na finitude deste; parece mais um prolongamento da vida, contíguo a ela, sua "vizinha": ela deseja visitar os parentes... da mesma forma que apelida o pássaro, associado ao reino celeste ${ }^{81}$, de "Senhora Vizinha". Um "lá" em que o puro "existir no mundo" infante distende seus limites de liberdade, desapego dos construtos sociais e do pensamento materialista, tornando-se mais próximo da existência dos santos ou dos loucos; ele será mergulho tão profundo no fluir da vida, na experiência mais direta do real, que coincide com o "lado de lá": morte tanto de nossa forma de existência quanto de nossa submissão às leis do mundo físico/objetivo. Essa aproximação com o sagrado que se faz na forma de um "salto" para "outra margem" guarda profundos ecos com o que Huineng, patriarca chinês do século VII explica como a experiência central do budismo:

Mahaprajnaparamita é um termo sânscrito do país ocidental; em língua tang significa: grande-sabedoria-outra-margem-alcançada [...] O que é Maha? Maha é grande [...] O que é Prajna? Prajna é sabedoria [...] O que é Paramita?: a outra margem alcançada [...] Apegar-se ao mundo objetivo é apegar-se ao ciclo do viver e do morrer, que é como as ondas que se erguem no mar; isto se chama: esta margem [...] Quando nos desprendemos do mundo objetivo, não há morte nem vida e somos como a água correndo incessante; isto se chama: a outra margem. (SUZUKI, apud PAZ, 2012, p. 128)

E quando Nhinhinha desaparece para o narrador, dá-se a primeira reviravolta do enredo, salto para outra margem, o mergulho absoluto na desrazão: a menininha passa a fazer milagres. É interessante que o expediente narrativo tenha abolido a

\footnotetext{
81 "Os passarinhos, estes cantavam, deputados de um reino" (p. 71), se lê mais adiante no conto. O Capítulo 5 deste trabalho se detém mais demoradamente na associação entre os infantes e os pássaros.
} 
condição de testemunha de nosso narrador para referir o elemento mágico. Ele, que nunca mais viu Nhinhinha, diz saber que por esse tempo ela começou a fazer milagres; mas, sabe como? Afinal, ninguém toca, de fato, o lá, o que é da ordem do mistério, do incognoscível... Para poder existir para nós, paradoxalmente, ele deve se manter o mais possível no domínio da indefinição, do aberto, não analisável mas intuível, não visto, mas sabido. E aqui o super-regionalismo de Rosa antepõe-nos uma realidade na qual do nada, brotará tudo, da ausência a presença, do silêncio o Verbo Criador:

\begin{abstract}
Nhinhinha, só, sentada, olhando o nada diante das pessoas: - "Eu queria o sapo vir aqui". Se bem a ouviram, pensaram fosse um patranhar, o de seus disparates, de sempre. Tiantônia, por vezo, acenou-lhe com o dedo. Mas, aí, reto, aos pulinhos, o ser entrava na sala, para aos pés de Nhinhinha - e não o sapo de papo, mas bela rã brejeira, vinda do verduroso, a rã verdíssima. Visita dessas jamais acontecera. E ela riu: - "Está trabalhando um feitiço...". Os outros se pasmaram; silenciaram demais. (p. 69)
\end{abstract}

Serviria aqui igualmente frase de outro conto rosiano sobre um desarrazoado: "E, pronto, refez-se no mundo o mito" (2001, p. 188). Nhinhinha passará a concretizar pela fala seus desejos. Mas são, como ficamos sabendo, sempre coisas "levianas e descuidosas, o que não põe nem quita" (p. 70), não são desejos de ordem prática ou utilitária. Ela parece continuar em sintonia com o fluir da vida, o móvel mundo, habitando seu "lá" insensato aos olhos dos adultos: "O que ao Pai, aos poucos, pegava a aborrecer, era que de tudo não se tirasse o sensato proveito."; "Pai e Mãe cochichavam, contentes: que, quando ela crescesse e tomasse juízo, ia poder ajudar muito a eles..." (p. 70, grifos nossos). Quando vem a seca, e os familiares tentam arrancar-lhe da fala a chuva, sua resposta primeira é "-Mas, não pode, ué..."; tentando apelar para o medo da fome e da morte, o fim dos alimentos e doces com a falta das águas, extraem dela somente seu velho bordão de entrega e desapego: "- Deixa... Deixa...". Da mesma forma, não falará a cura da mãe doente, mas por sua simples presença de afeto despertará nela a fé, em flagrante paráfrase da máxima crística "tua fé te curou": "Mas veio, vagarosa, abraçou a Mãe e a beijou, quentinha. A Mãe, que a olhava com estarrecida fé, sarou-se então, num minuto" (p. 70). A chuva, por fim, virá, não pelo medo, mas pelo anseio de beleza, quando Nhinhinha quer o arco-íris. E não 
será ele ponte entre o "aqui" e o "lá"? Ele, "sobressaído em verde e o vermelho - que era mais um vivo cor-de-rosa", dá as cores do caixãozinho desejado por ela, "caixãozinho cor de rosa, com enfeites verdes brilhantes" (p. 71). Foi nesse dia da chuva, do arco-íris, que a menina saiu de sua imobilidade habitual, pulando e correndo por casa e quintal. Aqui a ambiguidade e reversibilidade tão tipicamente rosianas se apresentam com força: a imobilidade é mobilidade, o silêncio é palavra, a insensatez é sabedoria, a carência é plenitude, o aqui é o lá, o ser é o não ser; neste momento em que Nhinhinha mais mergulha na relação sensorial com o mundo consuma-se seu "salto metafísico" para o lado de lá: "E, vai, Nhinhinha adoeceu e morreu" (p. 71).

A alegria é, agora, tristeza. Nhinhinha, a pequena, silenciosa, que não se fazia notada, figuração de tantas ausências, agora falta; e a falta da falta será, também, experiência de morte para os que ficam: "A Mãe, o Pai e Tiantônia davam conta de que era a mesma coisa que se cada um deles tivesse morrido por metade" (p. 71). Ela era a "outra metade" dos arrazoados, reverso de suas normalidades com o qual, em sua falta, eles entrarão em contato - a Mãe, desfiando o terço, rezará não as ave-marias, mas a sua condição de "Menina grande", em todo desamparo que a imagem condensa, nossa pequenez diante do mistério incognoscível, o "lá" da morte; e o Pai tocará o "tamboretinho", assento do pequeno, lugar do infante na sua leveza liberta do peso da existência aculturada, materialista, utilitária, que nós, com nosso "peso de homem", não podemos ocupar sem quebrar. A criança, aponta Benedito Nunes (2013, p. 66), guarda arquetipicamente o signo ambíguo da "anterioridade de ser", nossa ligação com a origem, estado primeiro de existência e, metafisicamente, o lugar original "de onde viemos", mas que é ao mesmo tempo um "porvir", forma de ser que nos fica como um devir ao nos libertarmos do peso da temporalidade; é lugar para onde nos dirigimos em nosso processo de reintegração à origem perdida, o que, para os místicos, pode dar-se no êxtase, mas para a maioria de nós, dá-se na morte. Por meio da existência infante de Nhinhinha, já de si partícipe do "Fora" tanto no ethos enigmático a romper com as formas conhecidas de ser quanto nas suas propriedades mágicas-miraculosas, e por fim, por meio de sua morte, os pais também comungarão desse "lá" originário e original, passado e porvir; a criança, a que "ainda não é", traz em si, não obstante, algo que temos a conquistar. 


\subsection{Para trás da Serra do Mim $^{82}$}

Antes de concluir, voltemos ao início, para revisitar a primeira imagem concreta aferida a um locativo espacial. Já apontamos que ao lado da referência religiosa - "lugar chamado o Temor-de-Deus", o "lá" de Nhinhinha nos propunha uma imagem de "anterioridade", figurada na frase que abre o conto: "Sua casa ficava para trás da Serra do Mim". É possível fazer coincidir esse "mim" com a imagem do sujeito, do "ego constituído", diria a psicanálise, daquele que se nomeia "eu" e, portanto, se identifica com suas vontades, desejos, preferências e aversões, com tudo aquilo, ademais, que os contextos culturais, familiares e históricos em que esse "eu" se insere agregaram a sua percepção de si mesmo e que determinam, assim, sua relação consigo e com o mundo circundante. "Para trás da Serra do Mim" seria, nesse sentido, uma existência "anterior" à constituição subjetiva, livre de tais condicionamentos e aculturações, o que não destoa da imagem infante de Nhinhinha configurada até aqui. A infância é costumeiramente e com acentuado saudosismo - vista como momento da existência em que menos nos encontramos "moldados", "enrijecidos" pelas fôrmas sociais.

Vimos, porém, que Nhinhinha figura bem mais do que a mera imagem da criança. Ela é "a menina de lá". Ela habita um vazio, um silêncio, uma "terceira margem" da qual poderá nascer o miraculoso, o instante genesíaco, o retorno a um existir infante, anterior à palavra enquanto signo, que nos lança no tempo mítico, da palavra enquanto coisa. É essa "anterioridade" que parece mais estreitamente dialogar com a "religiosidade", constituindo, ambas, aspectos do "lá" no conto.

Toda criação é precedida por uma clareira, um espaço primordial em que as estruturas não estão dadas... Que desse espaço original brote a existência é imagem frequente em mitos cosmogônicos de diversas culturas. É o Caos, no que ele tem de constitutivamente amorfo e imaterial, que precede o surgimento da Terra na Teogonia de Hesíodo; na Gênese Bíblica, do nada primordial Deus cria o Céu e a Terra, que era originalmente "sem forma e vazia"; em tradições chinesas, celtas e védicas (hindus), o mundo nasce de um ovo primordial no meio do vazio. ${ }^{83}$ Poderíamos, em escala bastante

\footnotetext{
${ }^{82}$ A professora Leyla Perrone-Moisés também usa esta frase de abertura do conto como título de seu artigo, publicado na revista SCRIPTA, Belo Horizonte, v 5, n. 10, p. 210-217, $1^{\circ}$ sem. 2002, embora seu "lá" adquira sentidos diversos dos que aqui exploramos.

${ }^{83}$ Do caos surgiu no princípio a Deusa de Todas as Coisas, Eurinome, nua e sem ter onde sustentar-se. Ela então separou primeiramente o céu do oceano e começou a dançar sobre as ondas, pondo em movimento, atrás de si, o vento norte que, como se fosse argila, ela tomou entre as mãos, e dele criou Ofion, a prodigiosa serpente. Atraído por sua dança, Ofion se enrosca no corpo de Eurinome e, como
} 
diminuta, da qual se exclui a dimensão numinosa do evento, vislumbrar as ausências constitutivas de Nhinhinha, que o narrador insistentemente reitera antes de relatar seus milagres, como um "espaço originário" de onde a criação poderá surgir ${ }^{84}$. E, junto com ela, a experiência ontofânica da linguagem, cuja referência ocidental mais difundida nos lança em esfera da religião cristã: "Deus disse: "Faça-se luz!" E a luz se fez." (Gn, 1:3), mas que tem forte ressonância nas vivências primitivas do homem com a palavra. Na esteira dessa dimensão inaugural, somos lançados a uma anterioridade, à dimensão arcaica da existência humana, seja em seu sentido historiográfico (época histórica em que o pensamento racional começava a pré-figurar-se), seja no sentido etimológico, que envolve a ideia de arkhé como um princípio inaugural, constitutivo e dirigente da experiência com a palavra poética em seu poder de plasmar realidades.

Jaa Torrano, em seus estudos da Teogonia de Hesíodo, ressalta que a historiografia denominou Arcaica (séc VIII - VI a.C.) a época em que começaram a germinar instituições que alterariam radicalmente as condições, fundamentos e pontos de referência da existência humana: a pólis, o alfabeto e a moeda. Na comunidade agrícola e pastoril anterior à constituição da pólis e adoção do alfabeto, Torrano ressalta a importância da oralidade na figura dos aedos (poetas-cantores):

Esta extrema importância que se confere ao poeta e à poesia repousa (...) em parte no imenso poder que os povos ágrafos sentem na força da palavra e que a adoção do alfabeto solapou até quase destruir. Este poder da força da palavra se instaura por uma relação quase mágica entre o nome e a coisa nomeada, pela qual o nome traz consigo, uma vez pronunciado, a presença da própria coisa (2006, p. 16-17).

Com as novas condições trazidas pela pólis, pela reforma hoplítica ${ }^{85}$ e pelo uso do alfabeto terá início a elaboração da prosa pelos primeiros pensadores jônicos,

vento do norte, faz amor com sua divina dançarina. Eurinome então transforma-se em uma pomba e, sobrevoando as ondas, põe o ovo que seria o universo, pedindo a Ofion que se enroscasse ao redor dele até que chocasse, dando origem a tudo o que hoje existe - planetas ,o sol, a lua, as montanhas e rios da Terra e todas as coisas que crescem e vivem. (LEEMING \& PAGE, 1994, p.53, tradução nossa).

${ }^{84}$ Compreendamos a ressonância entre este espaço e a imagem de "vazio" em certas cosmogonias não como o "nada absoluto". Nhinhinha, como vimos, apresenta uma existência plena, mas "esvaziada" dos preceitos e atitudes normativos na sua relação com o mundo e a linguagem, constituída predominantemente na imobilidade, na contemplação, no silêncio pontuado por palavras breves de suas estorinhas muito curtas, figurando uma essencialidade existencial: "Só a pura vida" (p. 68).

85 Transformações na estrutura militar. 
"pondo-se a linguagem a caminho de tornar-se abstrato-conceitual, racional, hipotática e desencarnada (na perfeição do processo, o nome se torna um signo convencionado para a coisa nomeada, cf. Crátilo, de Platão)" (2006, p. 17). Mas na arkhé da poesia oral, esta foi o eixo da vida espiritual dos povos, tornando presentes os fatos passados e futuros, tendo o "poder de fazer o mundo e o tempo retornarem a sua matriz original e ressurgirem com o vigor, perfeição e opulência de vida com que vieram à luz pela primeira vez" (2006, p. 17); não mera representação do mundo, mas poder de "fazer surgir" o mundo, os seres, os Deuses. Tal poder ontofânico da palavra perdura até hoje em nossa experiência poética ${ }^{86}$ e na bem mais prosaica experiência de temor em pronunciar palavras de mau agouro, nomes-tabu... Em Grande Sertão: Veredas, temos mais de quarenta sinônimos para o termo "diabo", empregados em nossa cultura popular para evitar que o nome presentifique o "Cujo".

A dimensão histórica/contextual do "arcaico" está, assim, plasmada também no "realismo regional" de Rosa, de forma que este transcende dimensão concreta/local. Afinal, não é, neste sentido, "arcaico" o universo de Nhinhinha? No sertão, anterior à configuração urbana (à pólis), em comunidade "agrícola e pastoril" (figurada nos trabalhos do Pai) e certamente excluída da alfabetização, para Nhinhinha, ainda alheada das relações mercadológicas e utilitárias com o mundo (advento da moeda...) o princípio da "palavra arcaica" revive. Enquanto, porém, no mundo historicamente arcaico, tal palavra está na boca do aedo, figura socialmente imbuída do poder da palavra, tanto poético quanto político, guardião da memória de seu povo, em nossa experiência moderna ela revive na figura diminuta, preterida, a criança, cujas palavras não configuravam mais do que "disparates" para a comunidade circundante. "Nhinhinha", além de diminutivo, ecoaria o pejorativo "Nhenhenhém", falatório vazio, na visão dos adultos racionais, mas que, em sua etimologia tupi, deriva de $N h^{\prime} e n g$, "falar"; Nh'enga, "fala, idioma, língua, palavra"87. "Para trás da Serra-do-Mim", na arkhé da linguagem, Nhinhinha congrega em si as dimensões do vazio, da imobilidade e do silêncio de onde nasce o próprio Verbo Criador. E quando ela "quebra o ovo do silêncio" 88 , ciente de seu poder - "Está trabalhando um feitiço..." -, é o mundo do

\footnotetext{
86 "No poema a cadeira é uma presença instantânea e total, que fere de um golpe a nossa atenção. O poeta não descreve a cadeira: coloca-a diante de nós", nos lembra Octavio Paz no ensaio "A imagem" (2015, p. 46)

${ }^{87}$ Vocabuário Tupi-Português do curso elementar de Tupi Antigo. http://tupi.fflch.usp.br/node/5 (Acessado em 08/07/2018, às 18h47)

${ }^{88}$ Expressão do conto "Os três homens e o boi dos três homens que inventaram um boi" (1969, p. 111), quando o silêncio, pausa, imobilidade é também origem da palavra criadora.
} 
logos, da palavra-símbolo, que se vê constrangido a calar-se: "Os outros se pasmaram; silenciaram demais" (p. 69).

A infância é, cronologicamente, a arkhé de nossa trajetória humana, mas também pode guardar essa dimensão simbolicamente "original" da existência, que flerta com a desrazão na ruptura com os paradigmas socio-culturais, na comunhão com o Fora, o mistério e, neste caso, o miraculoso. A conjugação entre estranhamento e graça de nossa Nhinhinha se deve a que ela é a única dentre os infantes rosianos que não faz a transição do lá para o cá... a meio caminho entre ambos, numa terceira margem, salta não para a loucura, mas para o milagre e, por fim, para a morte.

Mas o lugar permanece... "Lá", onde todos os opostos coincidem, onde a existência é o imperativo absoluto, onde o homem retorna a sua condição de criador... Esse inominável que escapa à razão, mas que todos aqueles que se aventuram a visitar, como os infantes, no delírio da desrazão, nos levam a tocar ainda que por breve instante. "Lá", o impossível linguístico, origem e fim da aventura humana, é, também, a "aventura da linguagem", e os poetas que mergulham nela como seu elemento metafísico, de reinauguração do mundo, tem nesse "lá" uma forma de re-ligar-se, na etimologia própria de "religião", ao instante genesíaco, à arkhé da linguagem, "para trás da Serra-do-Mim". Para Rosa, a metafísica de sua linguagem está, como o confessa a seu entrevistador alemão, no ato criador, em "querer se aproximar de Deus, às vezes demasiadamente", quando escreve:

Isto provém do que eu denomino a metafísica de minha linguagem, pois esta deve ser a língua da metafísica. No fundo é um conceito blasfemo, já que assim se coloca o homem no papel de amo da criação. O homem ao dizer: eu quero, eu posso, eu devo, ao se impor isso a si mesmo, domina a realidade da criação. (LORENZ, 1991, p. 83)

E "repetir o processo da criação" implica, para ele, em um retorno à origem, "voltar cada dia à origem da língua, lá onde a palavra ainda está nas entranhas da alma, para poder lhe dar luz segundo a minha imagem." (1991, p. 84).

Nhinhinha foi para lá... ou não foi? Ainda o aspecto estrutural da narrativa dá um salto mortale, no que nos propõe, enquanto leitores, uma experiência de fato do "lá", o aberto, inominável, incognoscível... Ao construir o relato na chave das 
ambiguidades - Nhinhinha tolinha e santa - colocar a narrativa do miraculoso fora do âmbito do testemunho, atribuir à sua morte tanto razões concretas - "diz-se que da má água desses ares" (p. 71) - quanto mágicas - "Nhinhinha tinha falado despropositado desatino [...] que queria um caixãozinho cor-de-rosa, com enfeites verdes brilhantes" (p. 71), e não nos dar a ver de fato o último milagre - veio, mesmo sem encomendarem, o caixãozinho "cor-de-rosa com verdes funebrilhos"? - fazendo-o antes existir como conversão de fé da Mãe, nos implica enquanto leitores na desrazão de que os infantes comungam, lança-nos fora da racionalidade dos binômios excludentes, em enredo para sempre aberto, obrigando-nos a habitar o imponderável, o religioso, o arcaico, o metafísico... o "lá". 


\section{Capítulo 4. O "Aldaz" Navegante}

\subsection{Brincando a realidade: o escritor e a criança}

"Quem inventou o formado, quem por tão primeiro descobriu o vulto de idéia das estórias?" (ROSA, 2001, p. 188). Assim indaga-se em pasmo Manuelzão, personagem de "Um Estória de Amor", diante da narrativa de Joana Xaviel, contadora de causos em torno da qual os convidados da festa se reúnem. De onde vêm as estórias? Como surgem? Porque alguns - os poetas, escritores, narradores - têm o dom de trazêlas à luz e outros não? Além das perguntas de fundo ontológico, podem surgir outras, de cunho quiçá antropológico ou psicológico: Porque narramos estórias? O que nos impele à atividade narrativa e que efeito ela tem sobre nós?

Dentre os que se debruçaram sobre tais questões, Freud identificou, como gérmen da escrita criativa e do devaneio adultos, o brincar infantil. As brincadeiras das crianças costumeiramente denominadas "faz de conta" não são outra coisa que narrativas, cuja extensão pode variar desde o pontual preparo de uma "comidinha" feita com grama, folhas, gravetos, e o que mais esteja ao alcance das mãos para ajuntar na panelinha, até longos enredos aventurescos, em que se contemple inclusive complexo manejo narrativo das categorias de tempo e espaço ${ }^{89}$. O fundador da psicanálise, que mais de uma vez buscou na etimologia das palavras pistas para os sentidos das imagens e teorias que perseguia, não deixou de notar que, em alemão, dá-se o nome de "Spiel"90 às formas literárias ligadas a objetos tangíveis, e que podem ser representadas, sendo os sentidos de "Lustspiel" (comédia) e "Trauerspiel" (tragédia) literalmente "brincadeira prazerosa" e "brincadeira lutuosa" (1908 [07], p. 150).

O componente lúdico da escrita rosiana sempre foi objeto de admiração de seus críticos, quando não os desconcertava! Criador de enredos, personagens, paisagens dirá Antonio Candido: "A província do sr. Guimarães Rosa, no caso Minas, é menos uma região do Brasil do que uma região da arte." (CANDIDO, 1991, p. 244) -, ele é antes e, indiscutivelmente, criador de linguagem. Brinca o corpo do texto desde sua

\footnotetext{
${ }^{89}$ Uma criança certa vez relatou-nos sua "brincadeira" favorita: no pomar do sítio de férias, ela e os amigos "em viagem de avião sobrevoavam uma floresta, mas subitamente uma tempestade os derrubava em terrível acidente. Perdidos na selva, dia após dia iam construindo suas casas na árvore, fugindo de tigres, aprendendo a cozinhar, encontrando outros seres prestativos ou perigosos, e essa "nova vida" se estendia por meses ou anos, até um possível resgate.

90 "Peça", em português, "play", em inglês, tendo o mesmo funcionamento deste último, portanto usado para "brincar", "tocar" (um instrumento), "jogar" e "atuar".
} 
macro até sua micro estrutura, das estruturas sintáticas até o próprio corpo da palavra. Subjaz a essa inventividade, segundo o próprio autor, uma relação com a língua enquanto "elemento metafísico", aquilo que, dependendo de seu manejo, cria uma realidade ou outra e, da mesma forma como as brincadeiras das crianças, é atividade levada muito a sério, em cujo cerne está o ato genesíaco de fazer existir o mundo. E é na "forma" da brincadeira, bem como na "forma" da escrita, que esta dimensão criativa se realiza: "Somente renovando a língua é que se pode renovar o mundo" (LORENZ, 1991, p. 88). Mas o ato criativo das crianças e dos escritores (e poderíamos dizer dos pintores, escultores, atores), na seriedade que lhe é inerente, se faz atravessar por uma profunda alegria e espírito lúdico. Há que "brincar" tanto a existência quanto a linguagem para que um novo mundo surja e, para tanto, ir além das convenções; Rosa optava pela grafia "dansa" em vez de "dança", supostamente porque o "Ç", ao contrário do "S", seria incapaz de dançar (MARTINS, 2008, p. 148) ${ }^{91}$. O autor que encara o ato de escrever como "[...] a técnica e a alegria do jogo com as palavras" (LORENZ, 1991, p. 88), ainda menino, aos 9 anos de idade, mesclava já "jogo" e "língua" quando aproveitava o intervalo das partidas de futebol em Cordisburgo para sentar-se ao meio fio com uma gramática alemã aberta ao colo, de cujo corpo sonoro das palavras extraía, como nos confessa, um deleite lúdico ${ }^{92}$.

Rosa, em mais de uma ocasião, afirmou sua escrita como a menos autobiográfica possível, enquanto alguns de seus leitores e críticos parecem sentir, como Haroldo de Campos, que "tudo o que ele faz é meio autobiográfico" (2011, p. 47). O paradoxo talvez se ilumine se pensarmos que, longe de simples transferência de pessoas e fatos vividos para o plano ficcional, a escrita rosiana está profundamente marcada não apenas por essa forma muito pessoal de brincar as palavras, mas também pela qualidade contemplativa do autor, seu modo particular de observar e apreender a vida - "Já passei muitas noites acordado - noites inteiras - para ver como é a lua, como

\footnotetext{
${ }^{91}$ No Léxico de Guimarães Rosa, da prof. Nilce Sant'Anna Martins, o vocábulo "dançadinho" vem acompanhado da explicação [O v. dançar e derivs. são grafados pelo A. com a letra s, substituída por ç nas edições da Nova Fronteira, de acordo com a ortografia vigente] (2008, p. 148). Em depoimentos como da Diretora Bia Lessa, quando da montagem de sua peça Grande Sertão: Veredas (2017), menciona-se a preferência de Rosa pelo "s" pois o cedilha "amarraria a perna do c na página, impedindoo de dançar", porém não encontramos em nenhum texto do autor essa mesma declaração.

${ }^{92}$ Retomamos o trecho já citado parcialmente no Capítulo 1: "Lá, em Minas Gerais, quando com 9 anos de idade, muito espantei os meus, ao comprar, por mim mesmo, uma gramática alemã, para estudá-la, sozinho, sentado à beira da calçada, nos intervalos de jogar, com outros meninos, football de rua. Só foi isto por inato amor às palavras recortadas de exatas consoantes: tais como kraft e sanft, welt e wald, e gnade, e pfad e haupt e schwung e schmiss." (MEYER-CLASON, 1968, p. 7, apud Cadernos de Literatura Brasileira IMS, 2006 p. 10)
} 
é a escuridão. Sem vê-la demoradamente é impossível descrevê-la"; "O que mais me influencia é a vida, a rua, o sertão" (ROSA, 1967, apud Cadernos de Literatura Brasileira IMS, 2006, p. 85). Ora, ambos processos são componentes bastante autobiográficos de suas experiências infantis; aquele já figurado na fusão "jogo/linguagem; gramática/futebol", enquanto o primeiro se deixa entrever em suas descrições das brincadeiras prediletas, de cunho altamente contemplativo:

"Prender formiguinhas em ilhas, que eram pedras postas num tanque raso, e unidas por pauzinhos, pontes para formiguinha passar. Aproveitar um fiozinho d'água, que vinha do posto das lavadeiras, e mudar-lhe duas vezes por dia o curso [...] Um dia ainda hei de escrever um tratado de brinquedos para meninos quietos" (PEREZ, 1991, p. 38)

A criança que brinca também observa o mundo. Sabemos que no brincar, longe de uma alienação da realidade, dá-se ato profundamente criativo no trânsito entre suas vivências do mundo objetivo e seu mundo interno de desejos, pulsões, paixões. Segundo o psicanalista Donald Winnicott, o espaço do brincar encontra-se numa "zona intermediária", não sendo experiência nem puramente subjetiva, nem puramente objetiva $^{93}$, dando-se em um lugar "entre" ambas. De maneira análoga, podemos pensar que do encontro entre esse espaço externo da realidade contemplada com o espaço interno da elaboração subjetiva é que nasce um "terceiro espaço": o espaço literário, criativo, não-biográfico e autobiográfico a um só tempo. Tais premissas nos dão a oportunidade de ressignificar o lugar da criança na obra rosiana. Mais do que mera categoria de personagem, ela se faz elemento fundante dos processos de composição do autor. Assim, adentraremos "Partida do Audaz Navegante", conto em que o ato de criar mundos, nas fronteiras entre brincar, narrar e escrever, se desdobra em mais de um plano narrativo.

O conto começa, como muitos das Primeiras Estórias, em um "espaço vazio", aparentemente desprovido de acontecimentos: "Na manhã de um dia em que brumava e chuviscava, parecia não acontecer coisa nenhuma." (ROSA, 2001, p. 166) ${ }^{94}$. O cenário inicial, campestre, é íntimo, doméstico e familiar; a água das chuvas constrange

\footnotetext{
${ }^{93}$ A ideia aqui esboçada será desdobrada mais adiante no capítulo.

${ }^{94}$ A partir daqui, todas as citações extraídas do conto terão apenas a referência de página.
} 
a família - uma mãe e suas três filhas pequenas, mais uma empregada e um priminho das meninas em visita de férias - ao recolhimento na cozinha, em afazeres prosaicos ou contemplativos. Cessando a chuva, a mãe visita a mulher doente de um vizinho enquanto as crianças passeiam até um riacho próximo. A menor delas, Brejeirinha, ao longo do conto inventa uma história sobre um "aldaz navegante" que parte em um navio, figuração do drama amoroso entre o priminho Zito e outra irmã, Ciganinha, os quais, fazendo as primeiras experiências sentimentais, encontravam-se brigados "de uma briguinha grande e feia", devido à qual o menino pensa em ir embora, dramático, debaixo de temporal. A história passará a brincadeira quando Pele, a terceira irmã, para zombar da caçula, identifica a personagem do "navegante" com um cogumelo branco o marujo de chapéu! - em cima de seu "navio": um monte de esterco à beira do riacho; a zombaria é, porém, transformada em brinquedo, e o "aldaz navegante" será enfeitado por todas as crianças antes de "partir para o mar", levado pelas águas cheias do rio, enquanto o casalzinho infantil refaz suas pazes.

Nada, de fato, "acontece" no enredo. Desde a casa, porém, até o riacho, no prosaísmo mais pueril das crianças, foi toda uma tradição literária - com seus grandes temas de amor, ciúmes, união, separação, medo, vergonha, viagens e navegações - que desfilou diante de nós, entretecida ainda à grande aventura humana do brincar/fabular enquanto ato criativo e operativo não apenas do mundo interno, mas externo das personagens, fazendo valer a fórmula lapidar de outro conto rosiano do mesmo livro: "Quando nada acontece, há um milagre que não estamos vendo" (2001, p. 119). É o milagre do ato criativo, a "alegria do jogo com as palavras", que acompanharemos no conto, num imbricamento entre dois planos narrativos - o do conto "A Partida do Audaz Navegante" e o da fábula do "Aldaz Navegante" criada pela protagonista Brejeirinha. A caçula infante, cuja linguagem ainda não plenamente cristalizada nas estruturas normativas da língua leva-a a descobrir tanto a palavra criativa e criadora quanto o mundo, brinca a existência desde a fruição estética da fabulação até sua potência de simbolização e ressignificação de experiências; da demanda de respostas do eu à empatia com o outro; da originalidade do indivíduo à sua inserção na tradição cultural. Ambos os planos narrativos se interpenetram e influenciam, fazendo da escrita verdadeiro entre-lugar, "terceira margem" em que, como no brincar, as fronteiras se esfumaçam, e o narrador/brincante não apenas cria as personagens, o jogo, mas é, ao mesmo tempo, criado por elas. Veremos, pois, em primeiro lugar o conto, para depois traçarmos os paralelos entre as duas molduras narrativas. 


\subsection{Navegar é preciso. Narrar também.}

O conto se inicia na cozinha da casa, no aconchego do "fogo familiar", metáfora do calor de afeto logo transposta à imagem da mãe em singelos cuidados, no preparo de alimentos e nos olhares para seus pequeninos ali ao pé. O ambiente é predominantemente feminino: as duas mulheres adultas, Mamãe e Maria Eva presumivelmente uma empregada ou cozinheira, que não deixa de trazer também no nome dois signos arquetípicos do feminino, a mãe de Cristo e a primeira mulher bíblica - ocupam-se da cozinha; as três filhas, Brejeirinha, Ciganinha e Pele dedicam-se ao que mais cabe a seus temperamentos e personalidades. Não há, curiosamente, menção ao pai; o único representante masculino é o priminho Zito. A casa ilhada pelas chuvas torna a cozinha ambiente uterino de amor e proteção, regido pela presença de "Mamãe", assim nomeada pelo próprio narrador, em identificação de seu ponto de vista com o das personagens, o que aproxima, a nós leitores, da vivência infantil, norteada antes de tudo pela segurança no amparo materno e admiração da criança pela figura quase onipotente da mãe: "Mamãe, a mais bela, a melhor. Seus pés podiam calçar as chinelas de Pele. Seus cabelos davam o louro silencioso"; "Mamãe cuida com orgulhos e olhares as três meninas e o menino" (p. 166). Dela é ainda uma "voz de vogais doçuras", "[...] aquela voz voável. Ela falava, e chovia era bátegas de bênçãos" (p. 169-170).

É significativo que um conto inteiramente arquitetado nas dobras da criatividade/brincadeira se inicie, e persista pontuado, pela figura materna; que sua importância seja fulcral na constituição do sujeito nos atesta a vasta bibliografia psicanalítica com variadas abordagens sobre o tema. Aqui, o que parece iluminar-nos o conto é sua exploração literária enquanto matriz da experiência infantil do brincar/fabular. O pediatra e psicanalista D. Winnicott postula que as primeiras experiências constitutivas do bebê recém-nascido, em que as necessidades e tensões instintuais são atendidas por uma mãe que a elas se adapta de forma "suficientemente boa", oferecendo-lhe o seio no momento certo, segurando-o nos braços de forma a oferecer conforto, mas não sufocamento, facilita ao bebê uma "ilusão de onipotência", isto é, a experiência de que ele próprio cria a realidade. Isto porque nesses estágios primários não há, ainda, a consciência do "eu", uma subjetividade individualizada, e do "outro", um não-eu, quer seja a mãe ou qualquer realidade externa. O bebê vive um estado de não separação. Daí que, se ao sinal de fome apareceu-lhe um seio, o bebê o vive como um produto de si mesmo, algo criado por ele. Ao processo de ilusão de 
onipotência terá de seguir-se um processo de desilusão gradativa - pressupondo um desenvolvimento psíquico saudável do sujeito que entra em relação com a realidade externa - tarefa que também cabe inicialmente à mãe facilitar, mas que todos deveremos continuamente realizar ao longo da existência. Winnicott, em sua teoria da ilusão-desilusão, afirma:

Presume-se aqui que a tarefa de aceitação da realidade nunca é completada, que nenhum ser humano está livre da tensão de relacionar a realidade interna e externa, e que o alívio dessa tensão é proporcionado por uma área intermediária de experiência (cf. Riviere, 1936) que não é contestada (artes, religião, etc.). Essa área intermediária está em continuidade direta com a área do brincar da criança pequena que se "perde" no brincar" (WINICCOTT, 1975, p. 28)

A psicanálise parece ter fundado nosso próprio processo de desenvolvimento em uma experiência criativa, de "controle mágico sobre o real" e, a partir dela, um contínuo processo de relação do sujeito com a realidade terá de equacionar mundo interior e exterior, na tensão entre aceitação da realidade objetiva e impulso do sujeito para existir de forma criativa ${ }^{95}$; na área intermediária dessa equação ela aparenta as experiências artísticas e religiosas à brincadeira infantil, valiosa porque constitui um entre-lugar, nem plenamente localizável na realidade psíquica interna, nem inteiramente pertencente aos fenômenos externos; a confiança na mãe, segundo Winnicott, permite um espaço potencial entre ela e o bebê, um espaço que os une e ao mesmo tempo os separa, favorecendo este "fruir de experiências baseadas num 'casamento' da onipotência dos processos intrapsíquicos com o controle que ele [o bebê] tem do real" (1975, p. 79). Nosso conto, assim, se inicia com uma imagem materna suprema, em sua presença benevolente, cuidadora, a partir da qual - tanto na vida quanto no conto - se desdobra a aventura humana da existência criativa.

Brejeirinha, a protagonista dessa aventura, é foco principal do olhar da mãe, e talvez pelo mesmo motivo é nela que nosso narrador se centrará: "Porque Brejeirinha,

\footnotetext{
95 "É através da apercepção criativa, mais do que qualquer outra coisa, que o indivíduo sente que a vida é digna de ser vivida". (1975, p. 95) A criatividade é, na psicanálise winnicottiana, intimamente associada à saúde, enquanto o indivíduo que percebe o mundo apenas como uma realidade à qual submeter-se ou se ajustar estaria, do ponto de vista psíquico, doente.
} 
às vezes, formava muitas artes". Valha-nos a ambiguidade semântica, uma das brincadeiras tão caras aos grandes autores! Não por acaso o adjetivo "brejeiro" figurativamente se traduz como "brincalhão, travesso, irreverente, levemente malicioso", no que vislumbramos a menina-arteira, que se estica dando com os pés em vários objetos, pula dando piruetas, rola nos cachos de bananas, descomposta, com o umbigo aparecendo; leva um tombo descendo a colina e, uma vez suja, sai feliz a correr junto da cachorrinha porque "agora pode não ter cuidado", indo lépida cravar varetas com que medir a cheia do riacho ${ }^{96}$.

As "artes" que formava, porém, eram também da esfera da criatividade. Como já mencionado, inventa a estória do "aldaz navegante" que ama uma moça e parte para o mar, porém mais do que o enredo, espanta-nos sua arte com as palavras. Brejeirinha, em sua linguagem infante, explora léxico complexo, à revelia da gramática, deslumbrando-se mais com o corpo fônico das palavras do que com seu significado, como nos diz o narrador: "porque gostava, poetisa, de importar desses sérios nomes, que lampejam longo clarão no escuro de nossa ignorância": - "Zito, tubarão é desvairado, ou é explícito ou demagogo?" (p. 168). Sua narrativa, já no nome do protagonista, quebra com o código partilhado, preferindo a palatal "l", cujo som e grafia, alongados, remetem a movimento vertical ascendente, algo irmanado ao que é "alto", "altivo", e que muito mais condiz com a audácia do navegante do que o fechado "u", que se encolhe a um canto, diminuído. A narrativa é pontuada, aliás, por inúmeras audácias linguísticas, desde o uso de termos eruditos, "O Aldaz Navegante, que foi descobrir os outros lugares, valetudinário" (p. 168), ao deslocamento de sentido usual, mesclando campos semânticos, ora criando nova e inusitada descrição "Então, mais, outro pensou, pensou, esférico, e disse [...]" (p. 169), ora privilegiando efeito sonoro, de ritmo ou rima "[...] só o mar, danado de ao redor, preliminar."; "Ele só a prevaricar... O amor é singular..." (p. 172). Difícil não enxergar, aqui, quase um duplo do autor que, como já vimos, também "formava muitas artes" linguísticas ${ }^{97}$, e que se dizia cultivar "[...] a idéia antiga, porém sempre moderna, de que o som e o sentido de uma palavra pertencem um ao outro. Vão juntos. A música da língua deve expressar o que a lógica

\footnotetext{
96 "Brejeiro", claro, também evoca "brejo", portando o signo da água que desempenhará papel fundamental tanto na macro-narrativa quanto na fábula que a personagem inventa.

${ }^{97}$ Manoel de Barros, relatando seu encontro com o escritor mineiro em 15.11.97, em Campo Grande, escreve: "A gente gostava de brincar sobre palavras. A gente gostava de examinar o corpo fônico das palavras. E também as significâncias e insignificâncias delas." Página do Jornal do Brasil de 19/11/1997, em homenagem a J. Guimarães Rosa, por ocasião dos trinta anos de sua morte.
} 
da língua obriga a crer." (LORENZ, 1991, p. 88), com a diferença que a personagem, por sua condição de infante, parece mais livre em seu descompromisso com a relação entre significante e significado, numa primazia por vezes quase total do som sobre o sentido: "Mas o mar veio, em vento, e levou o navio dele, com ele dentro, escrutínio" (p. 172, grifo nosso). Essa liberdade e mobilidade da linguagem ressoa na imagem dos pássaros com que tantas vezes Brejeirinha é descrita, "menina só ave", que "andorinhava", com seu "par de olhos passarinhos", "um azougue de quieta" (lembrando que azougue é nome de mercúrio, o deus mensageiro de pés alados), numa conjunção de movimento e eloquência que já se encontrava na boca do narrador de São Marcos (ROSA, 1978, p. 238), quando afirma que "as palavras têm canto e plumagem".

Antes disso, porém, Brejeirinha já "formava artes" de outra ordem; talvez sua produção artística venha mesmo de uma "forma de existir artística", profundamente radicada na busca pela apreensão do mundo e da linguagem não como atitude passiva de quem se informa, de sujeito que captura um objeto, e sim dinâmica viva, pulsante de criatividade, em que sujeito e objeto dançam juntos, se implicam num criar-se e recriarse contínuo. À estagnação da lógica cartesiana, que separa o eu e o outro e preconiza a supremacia da objetividade, Brejeirinha contrapõe o não-senso, a subversão - seja da língua, do pensamento, dos costumes -, a realidade subjetiva com sua primazia da beleza, da gratuidade e da intuição, que fazem dela verdadeira "artista da existência", em ato quase demiúrgico de recriar seu mundo e o daqueles ao seu redor.

Assim é que Brejeirinha se sai com máximas subversivas, como "Eu sei por que é que o ovo se parece com um espeto!" (p. 167); "Antes falar bobagens, que calar besteiras..." (p. 169). É ela, ainda, quem pressente a briga de Ciganinha e Zito, o misto de culpa e raiva deste, e a partir daí inventa a estória, em arte intuitiva e quase terapêutica de abolir a fronteira entre o eu e o outro - "Mas Brejeirinha tinha o dom de apreender as tenuidades: delas apropriava-se e refletia-as em si - a coisa das coisas e a pessoa das pessoas" (p. 168) - e de plasmar o conteúdo subjetivo em objetivo, transformar o caos em cosmos, dar imagem metafórica ao amorfo sentimento interdito: "'Zito, você podia ser o pirata inglório marujo, num navio muito intacto, para longe, lo-õ-onge no mar, navegante que o nunca-mais, de todos?"' (p. 168). Não é isso, afinal, o que faz a própria literatura - transformar o caos em cosmos? ${ }^{98}$ Vislumbramos,

\footnotetext{
${ }^{98}$ Ver, a esse respeito, "O direito à literatura", de Antonio Candido (2011, p. 179), artigo referência na área de estudos literários, em que se professa tal arte como um direito humano equivalente em
} 
também aí, seu ponto de contato com a psicanálise, que ajuda a transformar o caos interno do sujeito em um cosmos ordenado imbuído de sentido/significado. Brejeirinha, aqui, tanto poderia ser o escritor, em sua atividade lúdica da fabulação, quanto o analista que, junto de seu paciente, projeta-lhe a angústia subjetiva em uma imagem, com a qual ambos poderiam "brincar"99.

Alguns dos traços da personagem acima apontados não são estranhos à maioria das crianças - experimentação com a linguagem, liberdade com as palavras e gestos, gosto por travessuras, ânsia de aprendizagem ou mesmo a intuição mais apurada... Mas são as "muitas artes", em sua pluralidade de significados e intensidade com que a pequena as encarna, que fazem de Brejeirinha o centro do conto e o duplo do próprio narrador. Ela, cuja descrição assume o signo do diminutivo desde o nome até o semblante em meio aos cabelos, composto por "coisicas diminutas: a carinha nãocomprida, o perfilzinho agudo, um narizinho que-carícia." (p. 167), concentra paradoxalmente toda a potência criativa da qual comungam os grandes artistas - aqui, particularmente, os escritores.

A referência, aliás, à escrita, leitura e ao saber pontua os momentos iniciais aparentemente insignificantes do conto. Brejeirinha, enquanto estão todos confinados à cozinha, lê as 35 palavras da caixa de fósforos; Ciganinha, então brigada com Zito, lê um livro (ainda que, para ler, ela não precisasse virar a página...); Zito era também o nome do vaqueiro-poeta que integrava a comitiva da famosa viagem, que Rosa acompanhou, para transportar uma boiada da fazenda Sirga até a cidade de Araçaí, próxima a Cordisburgo, em 1952, recolhendo anotações que tanto lhe serviram na escrita principalmente de Grande Sertão: Veredas e Corpo de Baile. A protagonista diz, ainda, que vai "saber geografia" ou que "queria saber o amor", imagem completada por reflexão aguda: "- Sem saber o amor, a gente pode ler os romances grandes?" (p. 168). Menos uma pergunta acerca da censura de conteúdos impróprios, ela apõe a profunda percepção das implicações entre experiência/sabedoria e leitura, na pluralidade semântica que o termo nos dá: "saber" - deter certo conhecimento - é etimologicamente ligado a "sabor" - aquilo que "provamos", "experimentamos". Afinal, a experiência/ciência de certas coisas deve forçosamente preceder a leitura

importância aos demais, visto, dentre outros, o caráter de "coisa organizada" da obra literária, que favorece a ordenação de nossa própria mente e sentimentos e, portanto, de nossa visão de mundo.

99 Também na clínica winnicottiana, a prática analítica é vista como um brincar do analista e do paciente. "[...] a psicoterapia é efetuada na superposição de duas áreas lúdicas, a do paciente e a do terapeuta. Se o terapeuta não pode brincar, então ele não se adequa ao trabalho [...]" (Winnicott, 1975, p. 80) 
acerca delas, ou a leitura pode nos dar uma experiência de algo que, em nossa existência, ainda não tenhamos vivido, provado? A própria Brejeirinha coloca em ato a resposta quando cria sua narrativa amorosa com todos os conteúdos não apenas dos "romances grandes", longos, mas dos "grandes romances", os clássicos de nossa tradição literária. A crítica Adélia Bezerra de Meneses já fez notar que, cifrado no macro-enredo do conto e no micro-enredo criado por Brejeirinha, estão núcleos temáticos de uma das maiores referências narrativas de amor e viagem no mar, $A$ Odisséia (MENESES, 2015, p. 55-66).

Vale observar que o processo criativo de Brejeirinha nasceu de um encontro: entre o desejo subjetivo de "saber/saborear" o amor e a realidade objetiva da irmã Ciganinha e do priminho Zito, às voltas justamente com esta experiência. Como nasce a criação? De que fontes ela brota? É a pergunta sem resposta, o mistério que tentamos, de tempos em tempos, devassar... No conto, ela se nos afigura nesse território intermediário entre o eu e o outro, num instante fulgurante em que os anseios subjetivos se deixaram perpassar pela realidade objetiva - e, nela, pela subjetividade alheia tomando forma numa "terceira coisa". Aqui o escritor se separa definitivamente do analista; enquanto este brinca as imagens inconscientes/oníricas num âmbito particular e com um fim específico, cientificamente manejando-as para atender a seu paciente, aquele se deixa levar por elas despregado de finalidades terapêuticas individuais; na mescla entre trabalho e inspiração, ele pode sofrer o súbito arrebatamento, ser atravessado pela imagem que ganha corpo num fluir desmedido de excitação do ato criativo que tanto conjuga subjetividade e objetividade quanto alça-se do plano individual/particular ao universal:

"Mas Brejeirinha punha mão em rosto, agora ela mesma empolgada, não detendo em si o jacto de contar: - "O Aldaz Navegante, que foi descobrir os outros lugares, valetudinário. Ele foi num navio, também, falcatruas. Foi de sozinho. Os lugares eram longe, e o mar. O Aldaz Navegante estava com saudade, antes, da mãe dele, dos irmãos, do pai. Ele não chorava. Ele precisava respectivo de ir. Disse: - Vocês vão se esquecer muito de mim?" O navio dele, chegou o dia de ir. O Aldaz Navegante ficou batendo o lenço branco, extrínseco, dentro do indo-se embora do navio. O navio foi saindo do perto para o longe, mas o Aldaz Navegante não dava as costas para 
a gente, para trás. A gente também, inclusive, batia os lenços brancos. Por fim, não tinha mais navio para se ver, só tinha o resto de mar. Então, um pensou e disse: - "Ele vai descobrir os lugares, que nós não vamos nunca descobrir..." Então e então, outro disse: "Ele vai descobrir os lugares, depois ele nunca vai voltar..." Então, mais, outro pensou, pensou, esférico, e disse: - "Ele deve de ter, então, a alguma raiva de nós, dentro dele, sem saber..." Então, todos choraram, muitíssimos, e voltaram tristes para casa, para jantar..." (ROSA, 2001, p.167)

A citação é longa, mas justifica-se por conter o instante genesíaco do processo criativo que se desenrolará ao longo do conto. A imagem do "Aldaz Navegante", antes "inglório marujo", associada ao primo Zito, ganhou vida, e não mais reconhecemos nela os limites entre subjetividade e objetividade, ou entre o particular e o universal. $\mathrm{O}$ "Aldaz Navegante" tem pontos de ressonância com o primo Zito, que está de visita, distante, portanto, da mãe, dos irmãos, do pai, numa viagem de sozinho, ao mesmo tempo em que pensa em ir embora debaixo de temporal, empreender viagem na "água/mar", num misto de raiva e saudade; mas também guarda semelhanças com a própria Brejeirinha: ela, a "Aldaz Navegante", que em sua condição de criança empreende a aventura de "descobrir os outros lugares" - da linguagem, do conhecimento, dos sentimentos (Pele verbaliza esta imagem quando, interrompendo a narrativa, lhe diz "Você é uma analfabetinha 'aldaz'"); projeta, assim, na necessidade de "crescer" - ele precisava respectivo de ir - também a angústia da separação familiar e a despedida temporária do regaço materno protetor, que será vivida em breve, no passeio até o riacho. Do ponto de vista narrativo, Brejeirinha identifica-se, porém, com aqueles que ficam em terra - A gente também, inclusive, batia os lenços brancos - os que o primo Zito deixaria ao partir, a raiva ciumenta inconsciente por Ciganinha estendendo-se para o coletivo.

Toda a situação particular metamorfoseou-se, no entanto, na estória que toca em temas universais da experiência humana - o arquétipo do viajante que tem a coragem e audácia para deixar o familiar e ir de encontro ao desconhecido, viagem que precisa empreender só. O tema da saudade, da despedida e separação, permeado ainda pelo medo do esquecimento, encontra vasta expressão artística nas mais diversas culturas. Boa parte da tradição lusitana, com seu histórico de navegações, é atravessada 
por ele, desde as cantigas de amigo, cujo eu-lírico feminino aguarda ansiosamente o retorno do seu "amigo" que precisou partir para o mar, até o épico Lusíadas, com seu velho na praia do Restelo admoestando os navegadores que partem deixando família e pátria, em cena retomada por Fernando Pessoa a mesclar a voz medieval que indaga o mar "... quantas noivas ficaram por casar, para que fosses nosso, ó mar?" à voz contemporânea que responde afirmando a grandeza da alma diante de quaisquer sacrifícios individuais, sentimentais ou físicos. E a já mencionada matriz de muitos de nossos enredos ocidentais de viagem no mar, A Odisseia, traz igualmente, em paralelo às peripécias do navegador Ulisses a "descobrir os outros lugares", o drama da espera de Penélope, que recusa o esquecimento e aguarda o retorno. A morte no mar era, para os gregos, motivo de intenso pavor justamente pela perspectiva do esquecimento: desaparecido o corpo, sem honras fúnebres, sem a lápide no chão a ser cultuada por seu povo, o herói que não retornasse não poderia narrar seus feitos e, portanto, não se perpetuaria na memória de seu povo. Narrar e ser narrado era, para os gregos, muito mais do que entretenimento; ter sua vida e seus feitos lembrados, cantados pelos aedos, era o mais próximo que se chegava da imortalidade. A pergunta do "Aldaz Navegante" de nossa pequena narradora, "Vocês vão se esquecer muito de mim?", com seu advérbio de intensidade, inusitadamente apõe uma gradação ao esquecimento - ser um pouco esquecido é, ainda, existir, mas ser muito esquecido equivalha, talvez, a "morrer" para os que ficam.

A estória de Brejeirinha, longe de ser "de tolice, boba, boba", como profere, em zanga, Ciganinha, sem dúvida atingida imageticamente pela parte que lhe toca no seu incipiente drama amoroso, tem um valor ainda maior do que suspeita sua criadora que, indagada a respeito do motivo pelo qual cria, responde, como decerto os grandes escritores responderiam: "Porque depois pode ficar bonito, uê!". Ter sido criada num ato de "graça", a um só tempo "gracioso" e "belo", mas também "gratuito", sem fins utilitários, não significa que a arte seja desprovida de valor e, ainda que ela se afirme por sua beleza, os que dela se ocupam por fruição ou profissão sabem que seu caráter estético se desdobra em outras infinitas potencialidades. Uma delas é o poder da palavra sobre a própria realidade, que pode esfumaçar as fronteiras entre realidade e ficção de modo a abalar os pressupostos de supremacia da objetividade sobre a subjetividade, deixando-nos em dúvida se esta última é determinada por aquela ou vice-versa. Porque, a partir deste momento no conto, vários temas da narrativa criada por Brejeirinha serão vividos pelas personagens, seja na paisagem e seus fenômenos naturais, seja nas 
emoções com que se confrontam. A palavra - e aqui, a palavra narrativa - é um imperativo da existência, cria-se a partir dela e ao mesmo tempo a recria, e é por isso que "Antes falar bobagens, que calar besteiras...".

Finda a chuva, o grande tema da "viagem e separação" da estória será reeditado, em escala mínima, na realidade objetiva: as crianças saem de casa, em passeio até o riacho, separadas da mãe - "A gentezinha separou-se" (p. 170). Enquanto na fábula predominara a tristeza e saudade, aqui o passeio é motivo de alegria e entusiasmo. Chegando ao riachinho, tudo, para Brejeirinha, será brincadeira; seu olhar para ele é poético, lúdico, em personificação cômica que a leva a gritar-lhe "Bochechudo!", vendo-o cheio em bolhas, e a plasmar ainda outra figura metafórica: "A cachoeirinha é uma parede de água..." (p. 171). Brincando as imagens, deslocando sentidos, a poesia e as crianças se encontram e, por vezes, despretensiosamente subvertendo a lógica ordinária, nos fazem vislumbrar outras realidades. A pequena angra, onde o riachinho faz foz, é, para Brejeirinha, "A Ilhazinha dos Jacarés". Pele, a irmã mais velha, cujo nome remete-nos a nosso órgão mais extenso, fronteira entre o interior e exterior, que deste último colhe sensorialmente os dados para orientar-nos na relação com a realidade, encarna no conto um princípio prático e objetivo da existência: ajuda a mãe na cozinha, "diligentil", endireita Brejeirinha quando esta rola descomposta sobre os cachos de banana e, neste momento da narrativa, a confronta com o dado de realidade - "Você já viu jacaré lá?"; ao que a pequena responde - "Não. Mas você também nunca viu o jacaré-não-estar-lá. Você vê é a ilha, só. Então, o jacaré pode estar ou não estar..." (p. 171). A formulação de resposta de Brejeirinha vale por um tratado filosófico ou teológico: Não se vê a não existência. O vazio, o que não há, interessa menos como prova da realidade objetiva do que enquanto espaço potencial da criação, interregno do mundo subjetivo e objetivo; espaço da brincadeira, da criação, da religião; espaço em que o mundo não se nos impõe como dado absoluto ao qual nos subjugarmos, mas se abre para o apercebermos criativamente, em comunhão conosco. Aqui é o infante, brincante-narrador, que vive mais do que ninguém a dimensão da ausência como potência, tema, aliás, caro à visão de mundo rosiana. Lembremos o prefácio "Aletria e Hermenêutica" ${ }^{100}$, do livro Tutaméia, praticamente um tratado sobre a subversão da lógica a partir de "anedotas de abstração", que nos confrontam com a

\footnotetext{
${ }^{100}$ Este prefácio, em algumas de suas relações com as figurações infantis na obra rosiana, foi explorado no capítulo 2 deste trabalho.
} 
existência da não existência, aventando ainda definições sobre o "nada", e o belo ensaio de Paulo Ronai, "Os vastos espaços", acerca de Primeiras Estórias, cujos contos, se apresentam caráter vário de assuntos, situações, enredos, tom, construção e ritmo, têm como unidade os "desacontecimentos importantes": "O que existe dilui-se, desintegrase; o que não há toma forma e passa a agir" (RONAI, 2001, p. 19).

Nesse espaço potencial, a estória do "Aldaz Navegante" será reeditada, posto tanto a realidade objetiva quanto subjetiva tenham adquirido elementos que a narradora plasmará em sua nova versão, e que grifamos para melhor se ver a correspondência imagética: o riacho cheio, rumoroso, em águas fervorosas, remete Brejeirinha a seu medo do mar - "Brejeirinha não gostando de mar" -, que para ela "[...] não tem desenho. O vento não deixa. O tamanho..." (p. 171), ao mesmo tempo em que a briguinha do casal já se transformou em pazes, a raiva/ciúme dando espaço para o amor e o esquecimento para a lembrança. O anterior ouvinte solitário, Zito, é agora o casalzinho sentado junto numa pedra, para quem Brejeirinha se volta, e o "Aldaz Navegante", antes doendo-se por deixar a família, agora sofre por uma separação amorosa:

"O Aldaz Navegante não gostava de mar! Ele tinha assim mesmo de partir? Ele amava uma moça, magra. Mas o mar veio, em vento, e levou o navio dele, com ele dentro, escrutínio. O Aldaz Navegante não podia nada, só o mar, danado de ao redor, preliminar. O Aldaz Navegante se lembrava muito da moça. O amor é original..." (p. 172, grifos nossos)

Com o perigo crescente do mar revolto, o navio despedaçado, o medo fará com que a separação amorosa se intensifique, seja pelo esquecimento, seja pela distância física: "Ele, com o medo, intacto, quase que nem tinha tempo de tornar a pensar demais na moça que amava"; "A moça estava paralela, lá, longe, sozinha, ficada, inclusive, eles dois estavam nas duas pontinhas da saudade..." (p. 172). Brejeirinha pode brincar seu medo de mar na estória até o limite da morte eminente da personagem "o perigo era total, titular... não tinha salvação..." (p. 172). A aporia narrativa, diante da exigência da continuação, por Pele (sempre o princípio de realidade a nos pressionar!), será solucionada por um expediente considerado narrativamente "frágil" - tanto por esta irmã quanto pela crítica literária em geral - a introdução de uma personagem nova que 
subitamente aparece para salvar o "Aldaz Navegante": o "homem do farol", com quem o protagonista estaria "combinado", e que "acendeu a luz do mar".

Haveria regras para o brincar, assim como para o escrever? O princípio da coerência e da verossimilhança é um imperativo para ambos. A qualidade de "assemelhar-se ao verdadeiro" - não, diga-se, fazer-se cópia da realidade objetiva, mas manter com ela uma relação ao ser sustentada por lógica e coerência próprias -, talvez seja o que permite ao brincar/fabular sua qualidade de "entre-lugar", espaço intermediário entre mundo interior e mundo exterior. Seria a verossimilhança a ponte entre a subjetividade criativa e a objetividade externa que nós estamos sempre tentando equacionar? Porque, perdida ela, o caos não pode se transformar em cosmos, o "controle mágico sobre o real", sem seu lastro de realidade, não se faz.

Vale lembrar, à luz do jogo metalinguístico deste conto, trançando motivos da tradição literária e jogando com a moldura de uma narrativa dentro da outra, que a saída de Brejeirinha foi utilizada por mais de um grande escritor ao longo de nossa tradição cultural. Nos enredos trágicos de Eurípedes, um dos três grandes dramaturgos da Grécia Clássica, não era incomum a trama ter chegado a tal ponto que apenas um Deus exmachina podia salvá-la... E também é Deus, ao final do Fausto, de Goethe, quem salva o protagonista, malgrado o acordo deste com Mefistófeles. No universo criativo, somos por vezes constrangidos ao paradoxo de regras relativas; "[...] perdoamos os mais graves defeitos de enredo e de ideia aos grandes criadores de personagens", já nos disse o crítico Antonio Candido (et al., 2007, p. 54), ainda que, logo a seguir, afirme a construção estrutural como a maior responsável pela força e eficácia de um romance. O "homem do farol" de Brejeirinha, como um Deus ex-machina, também tem algo de "salvador luminoso", mas Pele rejeita justamente a fragilidade da construção estrutural, visto a personagem não estar entretecida na trama narrativa desde o início (o que não acontece, ressaltemos, no Fausto de Goethe): -"Não vale! Não pode inventar personagem novo, no fim da estória, fu!" (p. 173). Ao final do conto, porém, teremos, também nós, leitores, um "salvador luminoso"...

Descartando como inverossímil tal solução, e para caçoar de Brejeirinha, Pele ${ }^{101}$ acaba, ainda que com intuito de provocar a caçula, entrando no jogo da figuração

\footnotetext{
${ }^{101}$ A Prof ${ }^{a}$ Dr $^{\mathrm{a}}$ Yudith Rosenbaum, em sua fina leitura deste trabalho, deu o salto de aguda perspicácia ao enxergar em Pele algo do leitor cético, por demais pautado pelos imperativos da realidade, mas que vai se rendendo aos impulsos da ficção como modo libertário em meio aos limites realísticos. Também o leitor, que estranha os excessos da linguagem rosiana, seus arroubos imaginativos, acaba por
} 
metafórica ao olhar um monte de esterco, chato, semi-ressequido, quase alcançado pela cheia do riacho, com um cogumelo branco em cima, "de haste fina e flexuosa, muito longa: o chapeuzinho branco, lá em cima, petulante se bamboleava" (p. 173), e o identificar com o 'Aldaz Navegante'. Mas brincar é saber o móvel mundo ${ }^{102}$, e o que era desgosto da zombaria, pelo meio instante do colorido das flores que caem do colo de Pele, se transforma em alegria do jogo: Brejeirinha, "rápida no valer-se das ocasiões", aceita a imagem, emprestando-lhe o signo da beleza e perfume ao enfeitá-la com as flores e mais folhas, gravetos e raminhos, transformando o "esterco cogumeleiro" no "Aldaz Navegante".

Neste instante, o limite tênue entre fabular e brincar será ao mesmo tempo limite tênue entre realidade e fábula, interioridade e exterioridade - porque a tempestade que subjugava o 'Aldaz Navegante' salta para a realidade e subitamente ameaça o grupo de crianças, num trovão que "arrasta seus trastes", e o medo narrado será agora vivido por Brejeirinha; nesse jogo em que todos os limites se esfumaçam, a solução para a fragilidade do enredo e desfecho narrativo equivalerá a vencer tanto o medo do trovão quanto a distância que separara o casalzinho:

"O Aldaz Navegante, ele amava a moça, recomeçado. Pronto. Ele, de repente, se envergonhou de ter medo, deu um valor, desassustado. Deu um pulo onipotente... Agarrou, de longe, a moça, em seus abraços... Então, pronto. O mar foi que se aparvolhou-se. Arres! O Aldaz Navegante, pronto. Agora, acabou-se, mesmo: eu escrevi 'Fim'!" (p. 173)

Brejeirinha, a brincante-escritora... há um quê de estranha impossibilidade afim ao término tanto do narrar quanto do brincar. Eles, de fato, terminam? Adquirem uma única forma, definitiva? Sabemos de autores que compuseram mais de uma versão do mesmo texto - o conto "O Horla", de Guy de Maupassant, possui três - e de outros que, a cada nova edição de seus livros, reescrevem alguma coisa - Rosa, não por acaso, era um deles (Sagarana continuou sofrendo alterações até sua $5^{\mathrm{a}}$ edição ${ }^{103}$ ). Alguma

\footnotetext{
"sucumbir" prazerosamente aos seus enlevos e se enriquecer com eles para "retornar" transformado às leis da realidade.

${ }^{102}$ Expressão do conto "As margens da alegria" (ROSA, 2001, p. 50) que analizaremos no capítulo 5.

${ }^{103}$ Em carta à sua tradutora Harriet de Onís, Rosa confessa que "as 5 edições de Sagarana são todas diferentes, refeitas, remodeladas, remexidas. Por fim, para ver se eu conseguia deixar isso de lado, e me voltava para escrever outros e novos livros, o meu Editor, José Olympio, mandou matrizar ou estereotipar
} 
contingência limitante - interna ou externa - tem de intervir para pôr fim ao fluxo contínuo criativo do narrar-brincar, que de outra forma tenderia ao infinito: a mãe que vem buscar o filho na casa do amiguinho e o arrasta em revolta pela interrupção; o escritor balizado pelas datas limites de seus contratos editoriais, ou por seu próprio desejo de, finalmente, dar ao público suas obras. É significativo que nossa Brejeirinha, narradora oral, apele à imagem da escrita para conseguir fixar a estória sempre cambiante e dar-lhe um desfecho; etimologicamente, "escrever" é ato de fazer sulcos na matéria, marcar com o estilo, ponteiro ou haste de metal ${ }^{104}$, dando forma fixa às imaterialidades orais.

Mas o mundo é um lugar mágico (o de Guimarães Rosa e das crianças, certamente), em que a única lógica, por vezes, é a subversão da lógica... e o criador, malgrado sua condição de onipotência, não detém controle completo sobre sua criação - tema, novamente, tanto religioso quanto literário. Brejeirinha encerrou definitivamente a estória, mas a brincadeira permanece, e a levará, mais adiante, a reescrever toda a narrativa. O riacho, já golpeando o "Aldaz Navegante" criado por elas, repõe o tema da partida: "Ele vai para o mar?" Brejeirinha pergunta, enquanto Ciganinha e Zito vivem, "nas pontinhas da realidade", o agridoce do amor com a iminência da separação, ela finalmente verbalizando o seu medo: "Zito, você era capaz de fazer como o Audaz Navegante? Ir descobrir os outros lugares?" (p.174), e a resposta dele, confirmando sem confirmar, sintetiza o grande drama humano da dúvida entre ficar ou partir, satisfazer-se com o conhecido ou ansiar por algo mais; o indizível paradoxo do sentimento amoroso é resumido na imagem da rosa, antigo clichê, não fosse a brincadeira linguística do narrador também a reinventá-la: "Contudo, e felizes, alguma outra coisa se agitava neles, confusa - assim rosa-amor-espinhos-saudade" (p. 174). Finalmente é a vez de Ciganinha valer-se do jogo para equacionar seu mundo interno e externo, propondo, diante da dor da partida, transformar a separação em união/comunicação: que todos mandem, pelo "Aldaz Navegante", um recado para o mar, cada um colocando nele um objeto pessoal, uma parte de si... Não é isso, afinal,

\footnotetext{
a composição, guardando-a nos chumbos, e impedindo-me assim, de permanecer na classe de Danaide ou Sísifo. "Carta de J.G.R a Harriet de Onís, 23.04.1959. Fundo JGR (IEB/USP).

${ }^{104}$ Do latim scríbere, cuja raiz proto-indo europeia seria sker, "cortar", uma vez que a escrita primitiva se fazia por meio de sulcos com o estilete (PORTELLA, 1984, p. 110). O dicionário de português da google, proporcionado pela Oxford Languages, fornece a seguinte etimologia para "escrever": do latim scrībo,is,psi,ptum,ĕre, 'marcar com o estilo, traçar uma linha, gravar, desenhar, representar em caracteres, escrever'. https://languages.oup.com/google-dictionary-pt/ acessado em 09/09/2020, às $09 \mathrm{~h} 15$.
} 
toda brincadeira? Projeção de uma parte de si no exterior? Notemos que Brejeirinha nele coloca elemento metonímico da fala, da oralidade, "um cuspinho", que desdobra seu sentido para a marca artística da narradora-escritora quando ela o denomina "seu estilo".

Este simples ato ressignifica tudo, e Brejeirinha, como todo escritor "aldaz", terá a coragem de recomeçar, em nome da busca imperativa pela "verdadeira estória", outro tema exaustivamente visitado pela literatura, num misto de dor e gozo, esperança e desespero que o ato de criar encerra. Lembremos Carlos Drummond, com sua "Procura da poesia", confrontado com a pergunta esfíngica que as palavras apõem ao pobre poeta: "Trouxeste a chave?" (2012, p. 12) ${ }^{105}$, e o próprio Rosa, em confissão a seu tradutor italiano: "Eu, quando escrevo um livro, vou fazendo como se o estivesse 'traduzindo', de algum alto original, existente alhures, no mundo astral ou no 'plano das ideias', dos arquétipos, por exemplo. Nunca sei se estou acertando ou falhando, nessa 'tradução'" (2003, p. 99)

Ter atingido um saber-sabor, pelo que a experiência do brincar-fabular operou nos sujeitos, faz com que Brejeirinha diga:

" - Agora, eu sei. O Aldaz Navegante não foi sozinho; pronto! Mas ele embarcou com a moça que ele amavam-se, entraram no navio, estricto. E pronto. O mar foi indo com eles, estético. Eles iam sem sozinhos, no navio, que ficando cada vez mais bonito, mais bonito, o navio... pronto: e virou vagalumes..." (p. 174)

A ilusão de onipotência não é, portanto, tão ilusória assim. Tanto o brincar quanto o escrever são "atos". Retomando Winnicott, se brincar está nesta zona intermediária, não sendo "dentro" - objeto puramente interno -, nem "fora" pertencente apenas ao exterior, àquilo que o sujeito identifica como não-eu -, é porque nele se dá um controle mágico do sujeito sobre o "fora" e, "para controlar o que está fora, há que fazer coisas, não simplesmente pensar ou desejar, e fazer coisas toma tempo. Brincar é fazer." (1975, p. 63). E ao "fazermos coisas" operando a realidade externa, somos, neste mesmo ato, operados por elas, num imbricamento indissociável

\footnotetext{
${ }^{105}$ A beleza do poema pede a estrofe completa: "Chega mais perto e contempla as palavras./ Cada uma /tem mil faces secretas sob a face neutra/e te pergunta, sem interesse pela resposta,/pobre ou terrível que lhe deres:/Trouxeste a chave?
} 
da ação transformadora entre sujeito e objeto, interior e exterior, criador e criação. Não é outra coisa o que dirá o filósofo da educação Jorge Larrosa Bondìa ao explorar nosso "ato com as palavras":

"Eu creio no poder das palavras, na força das palavras, creio que fazemos coisas com as palavras e, também, que as palavras fazem coisas conosco. As palavras determinam nosso pensamento porque não pensamos com pensamentos, mas com palavras [...]. E pensar não é somente "raciocinar" ou "calcular" ou "argumentar", como nos tem sido ensinado algumas vezes, mas é sobretudo dar sentido ao que somos e ao que nos acontece. E isto, o sentido ou o sem-sentido, é algo que tem a ver com as palavras." (2002, p. 21)

A versão final de Brejeirinha não faz senão isto, dar sentido ao acontecido; ela refez o sentido da separação em união - o casal entrou junto no navio agora "estricto", etimologicamente afim a "estreitar", "aproximar" -, da dor em beleza - o mar, não mais "danado de ao redor", mas "estético", "cada vez mais bonito" -, da destruição do naufrágio em redenção luminosa - a luz do "homem do farol" transposta ao navio que "virou vagalumes". De forma menos explícita, mas não menos significativa, esta versão também transforma o sentido da própria identidade da irmã Ciganinha. Considerando que os ciganos são nômades, viajantes por excelência, Ciganinha está, na estrutura macro da narrativa, "enraizada" na sua casa e núcleo familiar - como Penélope obrigada à sina de esperar pelo retorno de Ulisses -, desencontrada, portanto, de seu próprio nome. Enquanto nas primeiras versões da narrativa de Brejeirinha este papel se mantém, na versão final, "verdadeira", a realidade se corrige por meio da subversão do cânone literário: o sujeito coincide consigo mesmo, e Ciganinha, identificada à "moça magra", se torna viajante junto com o "Aldaz navegante".

A realidade ainda aqui acompanhará a fabulação, com mais um momento de fusão entre ambas, pois eis que o trovão repõe Brejeirinha frente a frente com seu medo, mergulha-a em sua própria estória, o narrador identificando-a com o "aldaz navegante" pelo empréstimo do mesmo termo, "intacto", usado pela pequena: "Ela iria cair num abismo "intacto" - o vão do trovão?"; e, num último golpe brejeiro, travesso e irreverente, ele salvará sua protagonista pelo mesmo recurso que Pele havia criticado, o aparecimento súbito de um salvador, "Antes, porém, outra, fada, inesperada, surgia, 
ali, de contraflor": Mamãe, que vem abraçar a pequenina; no mesmo momento em que a separação do âmbito materno-protetor se desfaz, a separação do "Aldaz navegante" se consuma... o esterco enfeitado é arrastado pelo riacho, juntando na simbologia da brincadeira o mais rasteiro-escatológico com o mais elevado-sublime: "Suas folhagens, suas flores e o airoso cogumelo, comprido, que uma gota orvalha, uma gotinha, que perluz - no pináculo de uma trampa seca de vaca" (p. 175).

A mesma imagem luminosa, "vagalumes" e "gotinha de orvalho, que perluz", encerra a fabulação de Brejeirinha e a brincadeira das crianças. E a narrativa do conto? Ela se encerra voltando ao início, com a protagonista reafirmando sua primeira declaração de aparente não-senso: "Mamãe, agora eu sei, mais: que ovo só se parece, mesmo, é com um espeto!" (p. 175). Saber/sabor. A experiência aparentemente inocente da brincadeira/fabulação trouxe a Brejeirinha a prova do princípio filosófico do encontro dos contrários, coincidentia oppositorum, que os infantes rosianos tantas vezes encarnam. Ela, pequenina, feita de "coisicas diminutas", que ainda não sabe a geografia nem o amor, "analfabetinha audaz" coincide, como vimos, com os grandes artistas-narradores-escritores e, ao cabo de sua experiência entre brincar e fabular, consegue saber que o interior só se parece, mesmo, ao exterior, a separação à união, a raiva ao amor, o medo à coragem, a ficção à realidade, o grotesco ao sublime. E ela, a personagem, ao próprio narrador.

\subsection{Quem me narro?}

Ao longo deste capítulo, esbarramos mais de uma vez em pontos de contato entre o narrador e sua protagonista-fabulista - e, até, entre esta e o autor. O que vale ainda olharmos é como a narrativa enquanto jogo-brincadeira, na arte com as palavras que esfumaça por vezes as fronteiras entre ficção e realidade, interior e exterior, salta da esfera temática para realizar-se na própria estrutura do conto, que parece "brincada" pelo autor em mecanismos à altura das brejeirices infantis de sua protagonista.

A brincadeira se dá em torno de duas categorias narrativas decisivas, o tempo e o foco narrativo. Quem narra o conto? A frase de abertura, com o verbo "parecer", constrói algo como um narrador-observador, "Na manhã de um dia em que brumava e chuviscava, parecia não acontecer coisa nenhuma" (p. 166), o que se repete mais adiante na descrição de Brejeirinha à beira do riacho "Depois, se acocora, de entreterse, parece que já está até calçada com um sapatinho só" (p. 172) (grifos nossos). Outras 
passagens corroboram tal ponto de vista, como se quem narra tivesse com o espaço e as personagens narradas extrema familiaridade, conhecesse aquele cotidiano: "No campo, é bom; é assim"; "Sempre se enxergam o barranco, o galinheiro, o cajueiro grande de variados entortamentos, um pedaço de um morro - e o longe." (p. 166); "A gente via Brejeirinha: primeiro, os cabelos, compridos, lisos, louro-cobre; e, no meio deles, coisicas diminutas [...] (p. 167, grifo nosso). Neste último exemplo, porém, já se vislumbra um deslizamento para a categoria de narrador-personagem pelo uso da primeira pessoa que destacamos, alguém que não apenas observasse, mas estivesse presente, vivendo junto o narrado; assim também em "Meia-manhã chuvosa entre verdes: o fufío fino borrifo, e a gente fica quase presos, alojados, na cozinha ou na casa, no centro de muitas lamas." (p. 166, grifo nosso); Essa mesma primeira pessoa pode, ainda, assemelhar-se mais a um discurso indireto-livre, a narrativa colando-se à lente da percepção das crianças-personagens: "Se a gente se virava, via-se a casa, branquinha, com a lista verde-azul, a mais pequenina e linda, de todas, todas." (p. 170); "A gente se sentava, perto, não no chão nem no tronco caído, por causa do chovido do molhado." (p. 171), o que é reforçado pela escolha do termo "Mamãe", íntimo, usado apenas pelos filhos, em todos os trechos narrativos em que ela aparece, sua descrição em alguns deles claramente filtrada pelo olhar admirativo de filha: "Mamãe, a mais bela, a melhor. Seus pés podiam calçar as chinelas de Pele [...]" (p. 166). Em certos momentos, porém, há nítida sensação de um narrador onisciente, que sabe dos pensamentos e anseios de seus personagens: "Zito perpensava assuntos de não ousar dizer, coisas de ciumoso [...]" (p. 167); "Zito não respondia, desesperado de repente, controversioso-culposo, sonhava ir-se embora, teatral, debaixo de chuva que chuva, ele estalava numa raiva." (p. 168)

Há ainda outro recurso "brejeiro" para confundir-nos e borrar ainda mais os contornos do narrador: o uso do índice de indeterminação do sujeito. "Estava-se perto do fogo familiar, na cozinha, aberta, de alpendre, atrás da pequena casa" (p. 167); "Então, pediu-se licença de ir espiar o riachinho cheio" (p. 170); "Descia-se agora a outra ladeira, pegando cuidado, pelo enlameável e escorregoso [...] (p. 170); "O que se queria, aqui, era a pequena angra, onde o riachinho faz foz" (p.171); "Olhou-se. Era: aquele - a coisa vacum, atamanhada, embatumada [...] (p. 173). Optando por ele, em vez da terceira pessoa "estavam", "pediram", "desciam", "olharam", que necessariamente identificaríamos com as personagens do conto, o que o narrador faz é deixar um espaço entre a ação e seus sujeitos, a permitir que mais alguém o ocupasse... 
Ele próprio? Nós, leitores? Há algo como uma ficcionalização do próprio narrador, que se torna elusivo, sempre movente, ora onisciente, ora observador, cuja lente se coloca a pequena distância ou tão próxima que chega a misturar-se com a própria visão das crianças, de modo que não conseguimos "pegá-lo" inteiramente.

Ao lado do foco narrativo, os tempos verbais sofrem não menor oscilação. Se o pretérito imperfeito previsivelmente aparece em muitas das descrições narrativas "Mamãe, ainda de roupão, mandava Maria Eva estralar ovos com torresmos [...]"; "Suas meninas-dos-olhos brincavam com bonecas"; "Só o Zito, este, era de fora; só primo" (p. 166) -, enquanto o perfeito é reservado para ações pontuais - "Aí, esticou-se para cima, dando com os pés em diversos objetos"; "Brejeirinha pulou, por pirueta: - "Eu sei porque é que o ovo se parece com um espeto!" -, há momentos em que o presente se infiltra onde esperaríamos, pela coerência narrativa, um pretérito: "Nurka, negra, dormia. Mamãe cuida com orgulhos e olhares as três meninas e o menino" (p. 166); "Pele foi quem deu risada. Ciganinha e Zito erguem os olhos, só quase assustados. Quase, quase, se entrefitaram, num não encontrar-se. Mas Ciganinha, que se crê com a razão, muxoxa. (p. 168); "Voltava-se para a contra-margem, das mais verdes, e jogava pedras, o longe possível, para Nurka ir buscar. Depois, se acocora, de entreter-se, parece que está até calçada com um sapatinho só" (p. 172); "De fato, a água já se acerca do 'Aldaz Navegante', seu primeiro chofre golpeava-o. "Ele vai para o mar?" perguntava, ansiosa, Brejeirinha. Ficara muito de pé. Um ventinho faz nela bilo-bilo [...]" (p. 173) (grifos nossos). Essa súbita intrusão do presente em trechos supostamente pretéritos se dá ainda com outros marcadores, advérbios e pronomes relativos, como "Nesta hora, não. Brejeirinha se instituíra, um azougue de quieta, sentada no caixote de batatas" (p. 167); "Mas Brejeirinha punha mão em rosto, agora ela mesma empolgada, não detendo em si o jacto de contar [...]" (p. 168); "Agora, fechou os olhos que verdes, solene arrependida [...]" (p. 169); "Descia-se agora a outra ladeira, pegando cuidado [...]" (p. 170).

É certo que o presente tem efeito de aproximar-nos, a nós, leitores, do narrado; ele é o tempo da enunciação e, assim, a opção por ele engloba a nós e ao narrado na mesma atualidade. Segundo Harald Weinrich (apud NUNES, 2003, p. 39) as formas gramaticais dos tempos verbais na narrativa não estão meramente localizando ocorrências nas divisões do tempo; elas situam o leitor no processo comunicacional da linguagem: 
$\mathrm{O}$ pretérito perfeito, o imperfeito e o mais que perfeito indicam, pelo distanciamento e curso livre que imprimem à linguagem, que estamos contando ou narrando. Configuram, por conseguinte, uma situação de locução narrativa, ao contrário do presente, do passado composto e do futuro, que configuram uma situação de locução discursiva, de comentário. Esses tempos reclamam uma tensão no uso da linguagem, que aproxima o locutor do objeto. Orientam-nos no mundo do intercurso cotidiano, da ação e das decisões. Os do primeiro grupo orientam-nos no mundo narrado, no mundo das coisas distantes, não imediatas, fora das urgências do fazer, e que têm seu paradigma nos contos infantis." (NUNES, 2003, pp. 39-40)

Benedito Nunes comenta que essas duas situações de locução, narrar e comentar, não são estanques, se interpenetram, podendo-se optar, assim, por narrar empregando o presente e discorrer usando o pretérito, ou por vezes usar o pretérito para referir-se a uma situação presente ${ }^{106}$. O recurso parece, na lógica discursiva de Weinrich, ao mesmo tempo lembrar-nos que se trata de uma narrativa, uma construção fictícia, e nela mergulhar-nos, fazer-nos viver a atualidade de suas ações junto das personagens. E não é esse mesmo paradoxo que se reedita no brincar infantil? Freud, quando analisa o paralelo entre as brincadeiras de crianças e a ficção dos escritores, diz que a criança sabe perfeitamente que o mundo criado em sua brincadeira é da ordem da ficção, não da realidade, sem que isso a impeça de vivê-la profundamente e a sério: "Seria errado supor que a criança não leva esse mundo a sério; ao contrário, leva muito a sério sua brincadeira e dispende na mesma muita emoção. A antítese de brincar não é o que é sério, mas o que é real." (1908 [07], p. 149), e logo em seguida afirma que "O escritor criativo faz o mesmo que a criança que brinca." (p. 150). A oscilação de tempos verbais tensiona essa experiência do jogo e da ficção literária, em que distanciamento e aproximação, narrado e vivido, coincidem.

Esses expedientes com o tempo e o foco narrativo parecem, portanto, ir arquitetando o conto enquanto "jogo", esfumaçando os contornos nítidos do narrador e fazendo coincidir a experiência de uma voz que narra com a de uma voz que vive o

\footnotetext{
${ }^{106}$ Nunes dá como exemplo desta última forma o seguinte trecho de Orlando, de Virginia Woolf: "Na verdade, eram dez horas da manhã: Era o dia 11 de outubro. Era o momento presente" (apud NUNES, 2003, p. 40)
} 
narrado, o que se desdobra, para nós leitores, na coincidência da experiência de ouvinte do narrado com a de observadores/participantes do vivido. E temos, para completar o jogo ficcional, um narrador que narra uma personagem-narradora a tecer sua estória, o que nos dá, em um mesmo conto, mais do que dois enredos, dois estilos narrativos distintos. Como já ressaltamos, nossos dois narradores se mostram extremamente aparentados em seu manejo da língua. Ambos partilham uma atitude lúdica e criativa com a linguagem, valendo-se dos mesmos recursos: onomatopeias expressivas, "o fufío fino borrifo"; "a chuvinha no bruaar" (narrador); "Oh, as grogrolas!" (Brejeirinha), descrições inusitadas "Brejeirinha se instituíra, um azougue de quieta" (narrador); "O mar se encheu, o esquema, amestrador..." (Brejeirinha); invenção lexical "perpensava", "ciumoso", "controversioso" (narrador); "sem-nosco", “aparvolhou-se” (Brejeirinha), e trabalham sonoramente suas construções, em aliterações, assonâncias e rimas "[...] e o riachinho porém também, seu estuário já feio cheio, refuso, represado encapelado pororoqueja." (narrador); "O Aldaz Navegante não podia nada, só o mar, danado de ao redor, preliminar." (Brejeirinha).

Brejeirinha, porém, tem liberdades linguísticas das quais o narrador não partilha, como o nome de seu protagonista, "o Aldaz Navegante", que no título permanece grafado com "u", bem como na fala das demais personagens - “"Zito, você era capaz de fazer como o Audaz Navegante'? - pergunta Ciganinha”. Por estar ainda "aquém" da plena aquisição da linguagem em sua gramática normativa, seu manejo do léxico permite-lhe, como já mencionamos, exploração do corpo fônico das palavras em ruptura radical entre significante e significado, podendo ela pensar "desvairado, "explícito" ou "demagogo" como adjetivos para um tubarão. Além disso, seu discurso se distancia daquele do narrador no que tem de marcadamente infantil; as crianças, quando começam a incursionar pela criação narrativa, preferem períodos simples e curtos, apoiam-se em repetições várias, principalmente de pronomes e conjunções, abusam de certos marcadores temporais da ação e de expressões orais. As sucessivas versões narrativas de Brejeirinha apresentam, em maior ou menor grau, períodos curtos, repetições do pronome "ele", do advérbio "então", da expressão "pronto", da conjunção "e", além de algumas repetições de termos específicos em cada trecho. ${ }^{107}$

\footnotetext{
${ }^{107}$ Coloco aqui apenas um dos trechos como ilustração do estilo mencionado: "Então, pronto. Vou tornar a começar. O Aldaz Navegante, ele amava a moça, recomeçado. Pronto. Ele, de repente, se envergonhou de ter medo, deu um valor, desassustado. Deu um pulo onipotente... Agarrou, de longe, a moça em seus abraços... Então, pronto. O mar foi que se aparvolhou-se. Arres! O Aldaz Navegante, pronto. Agora, acabou-se, mesmo: eu escrevi - 'Fim'!" (p. 173)
} 
Aparentemente, a hierarquia entre narrador e personagem, aquele detendo domínio sobre esta, se mantém, Brejeirinha tendo seu discurso moldado pelo estilo do narrador e marcado pelos expedientes narrativos tipicamente infantis que este imprime a suas falas. Ao longo do conto, porém, algo curioso acontece... conforme a narrativa de Brejeirinha progride, começamos a colher sinais de que a narrativa-moldura aos poucos se deixa contaminar pelo estilo da narradora-personagem. Brejeirinha assim descreve o ápice dramático da separação entre o casal de sua estória, o Aldaz Navegante e a moça: "A moça estava paralela, lá, longe, sozinha, ficada, inclusive, os dois estavam nas duas pontinhas da saudade..." (p. 172). Quando, páginas adiante, o narrador vai descrever o diálogo de seu casalzinho, Ciganinha e Zito, no agridoce da união tingida por separação iminente, o faz pelo empréstimo, com pequena modificação, da expressiva imagem criada por Brejeirinha: "Segredando-se, Ciganinha e Zito se consideram, nas pontinhas da realidade [...]" (p. 174, grifo nosso). Para narrar esse mesmo diálogo, vale-se da repetição tipicamente infantil da conjunção "e" como forma de alternância entre as falas das personagens; além disso, tanto na passagem da narrativa para brincadeira, quando as crianças enfeitam o esterco cogumeleiro, como no momento em que as águas do riacho ameaçam levá-lo, o narrador incorpora o léxico da pequena em suas descrições: "Já aquela matéria, "o bovino", se transformava" (p. 173); "Mas, o "Aldaz Navegante", agora a água se apressa, no vir e ir, seu espumitar chega-lhe re-em-redor." (p. 174, grifos nossos). Após Brejeirinha narrar a versão final, a "verdadeira estória", porém, é que o estilo do narrador parece deixar-se contaminar plenamente pelo dela, em um parágrafo construído com períodos curtos, aliterações e rimas, repetição da conjunção "e", e flagrante empréstimo lexical: "intacto", usado anteriormente por Brejeirinha para descrever o medo do Aldaz Navegante, é agora usado pelo narrador para referir-se ao seu medo de trovões, e o termo "pronto", exaustivamente repetido pela pequena para encerrar seu relato, abre o parágrafo narrativo. Por fim, o recurso do salvador luminoso, o "homem do farol" de Brejeirinha, é absorvido pelo narrador, que traz a figura inesperada da Mamãe para resgatar a pequena:

"Pronto. O trovão, terrível, este em céus e terra, invencível. Carregou. Brejeirinha e o trovão se engasgam. Ela iria cair num abismo "intacto" - o vão do trovão? Nurka latiu, em seu socorro. Ciganinha, 
e Pele e Zito, também, vêm para a amparar. Antes, porém, outra, fada, inesperada, surgia, ali, de contraflor.

- "Mamãe!" (p. 175)

Para narrar, finalmente, a cena em que todos veem o materializado personagem da estória partindo com as águas do riacho, o narrador abre mão inclusive das aspas com que vinha sinalizando os empréstimos lexicais de Brejeirinha, para incorporar, em seu próprio discurso, a forma "Aldaz": "O Aldaz! Ele partia. Oscilado, só se dançandoando, espumas e águas o levavam, ao Aldaz Navegante, para sempre, viabundo, abaixo, abaixo." (p. 175)

Se Brejeirinha foi moldada pelo narrador, em suas descrições e estilo narrativo, ele não foi menos moldado por ela. Poderíamos ficar em dúvida se a linguagem de Brejeirinha se deve à dele ou vice-versa. A criança brincante-narradora, na plasticidade de sua linguagem, emerge ao final do conto como verdadeira "mestra", cuja lida com as palavras o narrador incorpora em sua própria arte. Zito, que no conto está no papel de ouvinte da história, além de nome do vaqueiro poeta é também diminutivo de Joãozito, apelido de Rosa na infância, e podemos pensar que o narrador-escritor é, antes de tudo, um "escutador", que se deixa impregnar pelas palavras daqueles que o cercam; Rosa, sabemos, foi um grande escutador do vaqueiro Zito, da contadora Joana Xaviel, de Manoelzão, das paisagens e seres do "sertão", e não lhe seria estranho o jogo de reversibilidade entre criador e criatura, criando personagens cuja força narrativa impregnasse, por sua vez, a sua própria escrita.

A subversão da lógica hegemônica, condensada no saber "brejeiro" de coincidência de opostos com que a protagonista abre e fecha o conto - "Eu sei porque o ovo se parece com um espeto"-, realiza-se, portanto, não apenas nos conteúdos narrativos que, como vimos, apontam que o mundo subjetivo se parece ao objetivo, a separação à união, a raiva ao amor, o medo à coragem, a ficção à realidade, o grotesco ao sublime, mas na própria estrutura narrativa, quando o tempo do narrado se parece ao tempo do vivido, o narrador onisciente ao observador, a terceira à primeira pessoa, e a protagonista, ao próprio narrador, neste jogo em que as palavras de um resvalam para as do outro, em que criar um conto é, ao mesmo tempo, ser criado por ele. 


\section{Capítulo 5. Margens e Cimos}

\subsection{O Menino e o Mundo: "E vinha a vida."}

"Cuidado, leitor, ao virar estas páginas". Assim Álvares de Azevedo alerta os que leem sua Lira dos Vinte Anos, cuja primeira parte ele identifica à doce face de Ariel, antes de adentrarem a segunda parte, marcada pelos traços demoníacos de Caliban. Poderíamos abrir o preâmbulo da última parte deste trabalho, salvaguardadas as devidas proporções, com nota semelhante. Aqui nos depararemos com imagens da infância que, se trazem ainda alguns pontos de contato com as primeiras, delas se separam radicalmente pelo que figuram como experiência da "queda do paraíso", o confronto com a realidade em sua dimensão de finitude, perda, incerteza, e que encerram, portanto, desilusão, dor, angústia. Trata-se de enredos cujas crianças, de alguma forma, perdem algo desse lugar infante até então intocado em sua pura alegria, em sua graça absoluta, em sua onipotência diante dos desejos, da linguagem e até da própria realidade.

Caminharemos ao lado d' O Menino, protagonista de "As margens da alegria" e "Os cimos", primeiro e último contos de Primeiras Estórias, em sua experiência de "primeiro encontro com a realidade", como o próprio Rosa a definiu a seu entrevistador Fernando Camacho (1978, p. 45). É verdade que as crianças que acompanhamos até aqui não estavam, de forma alguma, apartadas da realidade; Dja/Iaí confronta-se com a cobra engolindo o sapo no brejo enlameado, Nhinhinha tem o encontro com o limite último, a própria morte, e Brejeirinha depara-se com o sofrimento da separação amorosa entre a irmã e o primo, além de enfrentar seu próprio medo do mar e das tempestades; mas, para nenhuma delas este encontro foi vivido definitivamente enquanto dor e angústia. Lembremos: em "Tresaventura", não é a morte que se impõe como realidade inexorável, mas a vontade e ação da criança que impõem a vida e a bondade sobre o inexorável ciclo, rompendo-o com uma pedrada que torna a cobra novamente "boa" e salva o sapo, enquanto a menina retorna a casa para dormir entre "gradis de ouro da alegria"; a experiência da morte jamais foi concebida pela "menina de lá" como angústia do fim, é antes um desejo - ela que queria visitar os parentes mortos -, vivida na chave da luminosidade e alegria: corre e pula por casa e quintal no dia em que pede um caixãozinho cor-de-rosa com enfeites verdes brilhantes; e em 
"Partida do Audaz Navegante", a angústia de separação do casalzinho vira enredo na boca de Brejeirinha e posteriormente brincadeira das crianças, que transformam a partida em comunicação enviando, pelo "audaz navegante" - o esterco cogumeleiro enfeitado de flores e galhos - um recado para o mar, enquanto o medo de Brejeirinha diante dos trovões, quando está próximo do ápice, reverte-se em conforto e segurança, com a presença salvadora do colo materno que a ampara.

Nosso Menino, porém, viverá em toda a potência o desamparo e sofrimento diante das contingências da vida, a violência dos homens e da natureza, a descoberta da inexorabilidade do tempo, da finitude, da morte... a perda de entes e coisas e, com ela, a da ilusão de onipotência, do lugar infante que vive como infinitude a segurança, o senso de pertencimento e completude, a alegria e a beleza. Ainda assim... algo emerge dessas experiências que configura não uma "perda da infância" nos contos, mas um "aprendizado da infância", que permitirá aos pequenos entrar em relação com a realidade sem sucumbir a ela. Sendo nosso foco os dois contos apontados, impossível não notarmos a relação entre este Menino e o protagonista Miguilim, da novela "Campo Geral", que será, portanto, convocado algumas vezes, em chave comparativa ${ }^{108}$.

\subsection{Alegria, um rio?}

"Esta é a estória. Ia um menino, com os Tios, passar dias no lugar onde se construía a grande cidade." (ROSA, 2001, p. 49) ${ }^{109}$ Assim abre-se o livro e o conto; assim encontrou o narrador um modo de antecipar-nos o que virá, literatura que se faz ao mesmo tempo particular, específica, "a estória", esta apenas que temos diante de nós, não outra, e universal, "a estória" única, que se repete para todos, irmanando-nos em nossa viagem humana; viagem "descendente", da eternidade paradisíaca da infância ao duro chão temporal da vida, prefigurada na primeira parte ${ }^{110}$ do conto desde o alto voo do avião em que o menino embarca com os Tios até seu pouso no lugar "onde se construía a grande cidade". A parte I é toda feita para vivermos, por meio das sensações do menino, este lugar infante, particular e universal, em que a realidade se tinge de

\footnotetext{
108 Vânia Maria Resende aponta brevemente uma relação entre essas duas personagens a partir da imagem do peru (1988, p. 31). Aqui pretendemos ampliar um pouco os pontos de contato entre ambos.

${ }^{109}$ A partir daqui, todas as citações dos contos "As margens da alegria" e "Os cimos" virão acompanhadas apenas pelo número da página da referida edição.

${ }^{110} \mathrm{O}$ conto é dividido em cinco partes, identificadas por algarismos romanos, e nos valeremos desta notação para fazer referência a elas neste capítulo.
} 
fantasia, "Era uma viagem inventada no feliz; para ele, produzia-se em caso de sonho", quando, em prolongamento de nosso narcisismo primário, somos o sol em torno do qual tudo e todos orbitam, "Respondiam-lhe a todas as perguntas, até o piloto conversou com ele" (p. 49); estado de plenitude em que não se experimenta falta ou desconcerto do mundo: "As coisas vinham docemente de repente, seguindo harmonia prévia, benfazeja, em movimentos concordantes: as satisfações antes da consciência das necessidades"; "Ainda nem notara que, de fato, teria vontade de comer, quando a Tia já lhe oferecia sanduíches." (p. 50) Onde não há senso algum de finitude ou carência, o receio, dúvida ou angústia inexistem; o sujeito ainda não está fragmentado pela dualidade constitutiva da existência, "Sentava-se, inteiro, dentro do macio rumor do avião: o bom brinquedo trabalhoso", conhece apenas segurança, certeza da proteção e bondade do mundo; o porvir desconhecido, "não sabido", "espaço em branco", não assusta, pois dele só se concebe que reserve ainda "mais", que alargue a experiência de liberdade e respiro infinitos:

"A vida podia às vezes raiar numa verdade extraordinária. Mesmo o afivelarem-lhe o cinto de segurança virava forte afago, de proteção, e logo novo senso de esperança: ao não sabido, ao mais. Assim um crescer e desconter-se - certo como o ato de respirar - o de fugir para o espaço em branco. O Menino." (p. 49)

O fim do parágrafo, como se vê, consuma a transformação do particular, comum, um menino, em universal, O Menino. É forçoso lembrar, porém, que estamos diante de rara configuração social para personagens rosianas. Trata-se de menino de condição socioeconômica notadamente privilegiada, a viajar de avião especial, de apenas quatro lugares, com fartura de guloseimas, acesso à leitura e instrução (revistas e mapas que o Tio lhe coloca sobre os joelhos), todas condições que o tornam virgem em qualquer tipo de carência ou frustração. Muito diferente de Miguilim, cujas contingências externas, geográficas e sociais, o sertão em sua dureza, as tempestades ameaçadoras, a pobreza em que vive a família, fazem com que até suas memórias mais remotas sejam já tingidas com as cores misturadas do gozo e da dor ${ }^{111}$. O tratamento

\footnotetext{
${ }^{111}$ Miguilim lembra-se de ocasião em que, pequenino, leva uma pedrada na cabeça, atirada por um menino mais velho que viu em suas palavras diante do peru no quintal uma provocação; e do banho de sangue de tatu que tomou por ocasião de grave doença que teve. Ao mesmo tempo, recorda-se de estar em meio a moças cheirosas que o mimavam, dando-lhe um "de-beber quente, que cheirava a claridade"
} 
dispensado pelos adultos aos pequenos, em ambos os casos, guarda diferenças abissais, basta lembrarmos as surras e castigos que Miguilim recebe, por vezes imerecidos, além dos corriqueiros abusos verbais do pai, e o "afago de proteção" dado ao Menino por aqueles que tomavam conta dele "justinhamente". É graças a essas condições que, no conto em questão, acompanhamos a primeira experiência, de fato, da "queda do paraíso" do Menino, tanto mais pungente quanto contrastante com sua apercepção da realidade até então. Ela já fora sorrateiramente prenunciada, aliás, na imagem com que o narrador descreve seu entusiasmo, ele que "... fremia no acorçôo, alegre de se rir para si, confortavelzinho, com um jeito de folha a cair" (p. 49, grifo nosso), da mesma forma que a passagem da vivência de eternidade para o aprendizado da impermanência está contida na mistura de perspectivas que a janelinha lhe proporciona. De lá ele olha o mundo do alto, visão graciosa e celeste, quase o ponto de vista do Criador, "desmisturado" de tudo, acima do humano revelado em sua pequenez: "as nuvens de amontoada amabilidade, o azul de só ar, aquela claridade à larga, o chão plano em visão cartográfica (...) e, além, baixa, a montanha. Se homens, meninos, cavalos e bois assim insetos? Voavam supremamente." (p. 50) Mas o narrador já dissera que "Seu lugar era o da janelinha, para o móvel mundo", e neste móvel mundo, onde nada permanece como é, onde o intervalo entre a plenitude e a carência, o gozo e a dor, a vida e a morte se faz menor que um minuto, ele aterrissará.

As partes II e III do conto nos dão a criança na plenitude de seu maravilhamento pela relação sensorial com o mundo. "A criancinha conhece o mundo através da boca (...) Ela vê, ela experimenta, ela sente, ela toca em todas as coisas que pensa." (DUHAMEL, 1923, p. 35). Para o Menino, a visão será porta fundamental por onde recebe o êxtase do novo que se apresenta. O olhar é nosso acesso à face do mundo em suas miríades de formas, dimensões, cores e tonalidades; pela visão somos atravessados por beleza ou terror, luminosidade ou trevas. Heloísa Vilhena de Araújo (1992), em seus estudos sobre Corpo de Baile, aponta uma correspondência entre as sete novelas e a simbologia dos sete planetas segundo delineada no texto Timeu, de Platão, desdobrando-a ainda em correlação com os sentidos do corpo; neste esquema, a novela "Campo Geral" relaciona-se ao Sol e à visão, domínios, na mitologia grega,

e colocando-o para engatinhar "na alegria de um jardim" com frutinhas vermelhas que tinham "cheiro pingado, respingado, risonho, cheiro de alegriazinha." (ROSA, 2001, p. 30-31) 
do deus Apolo, que preside também sobre as belas formas ${ }^{112}$; aqui, mais um ponto de contato entre Miguilim e o Menino, cujos olhos se fazem portas da percepção, por vezes no engano, outras no aprendizado, mas de pronto permeáveis à beleza luminosa do mundo. As referências ao olhar já começam no campo de pouso e chegada à casa, "O menino via, vislumbrava. Respirava muito. Ele queria poder ver ainda mais vívido - as novas tantas coisas - o que para os seus olhos se pronunciava." (p. 50-51, grifos meus), se intensifica no terreirinho do quintal, onde a visão das altas árvores e os ruídos da mata lhe instigam a imaginação: "Dali podiam sair índios, a onça, leão, lobos, caçadores? Só sons.", mas atinge seu ápice diante do peru, em trecho de tal força plástica que merece transcrição completa:

\begin{abstract}
"Senhor! Quando avistou o peru, no centro do terreiro, entre a casa e as árvores da mata. O peru, imperial, dava-lhe as costas, para receber sua admiração. Estalara a cauda, e se entufou, fazendo roda: o rapar das asas no chão - brusco, rijo - se proclamara. Grugulejou, sacudindo o abotoado grosso de bagas rubras; e a cabeça possuía laivos de um azul-claro, raro, de céu e sanhaços; e ele, completo, torneado, redondoso, todo em esferas e planos, com reflexos de verdes metais em azul-e-preto - o peru para sempre. Belo, belo! Tinha qualquer coisa de calor, poder e flor, um transbordamento. Sua ríspida grandeza tonitruante. Sua colorida empáfia. Satisfazia os olhos, era de se tanger trombeta. Colérico, encachiado, andando, gruziou outro gluglo. O menino riu, com todo o coração. Mas só bisviu. Já o chamavam, para passeio" (p. 51, grifos nossos)
\end{abstract}

O trecho talvez cause espanto e inveja a tantos que, tendo já visto um peru, jamais o apreenderam nessa potência de formas, cores, sons... Aqui, uma das maestrias do texto rosiano, cujo foco narrativo desliza, colando-se ao olhar e impressões da criança, enquanto mantém o manejo poeticamente refinado da linguagem, até lograr reproduzir para nós o impacto de olhar inaugural maravilhado valendo-se de expressões nada infantis, "colérico, encachiado", "laivos de um azul claro, raro". O que se reproduz, aqui, pela linguagem, é a experiência infantil de apreensão do mundo e

\footnotetext{
${ }^{112}$ Em carta a seu tradutor italiano a respeito de "Campo Geral", Guimarães Rosa especificamente identifica a personagem de Seo Aristeu, apicultor com poderes de cura, ao deus Apolo (ROSA, 2003, p. 39), e Heloísa Vilhena de Araújo estende a analogia com o astro rei para toda a novela.
} 
relação com ele por meio não do intelecto, mas predominantemente da sensorialidade. O narrador nos leva a experimentar em nosso próprio corpo o alumbramento do Menino, o que ele viu e sentiu nos fere de um só golpe. Isso porque, além dos trechos grifados, que mais explicitamente referem-se à visão e ao prazer da beleza que a acompanha, o trabalho poético com o corpo das palavras parece voltado para fazer delas emergir o sensório. Em "Grugulejou, sacudindo o abotoado grosso de bagas rubras", por exemplo, o som onomatopaico do animal transborda para as aliterações e assonâncias dos termos que descrevem o movimento, formato e cores do pescoço do bicho; e os olhos que recebem as formas plasmarão adjetivos como "redondoso" para que as letras e os sons ganhem também o corpo redondo do peru. Erich Soares Nogueira (2005) magistralmente explora, em ensaio a respeito de "Campo Geral", a forma pela qual a experiência sensorial, elemento fundante do universo não racional, como já vimos, tão caro à literatura rosiana, se faz meio de elaboração da própria linguagem narrativa. Será coincidência que uma das primeiras visões de alumbramento de Miguilim tenha sido, também, diante de um peru? Nogueira ressalta o trecho "abria roda, se passeando, pufo-pufo - o peru era a coisa mais vistosa do mundo, importante de repente, como uma estória." (ROSA, 2001, p. 30), para apontar-nos como a expressão delicadamente infantil, "pufo-pufo", guarda um ineditismo que se enlaça à percepção inédita que Miguilim tem de um peru, tornando o corpo da linguagem e o corpo da experiência - da personagem e do leitor - uma coisa só ${ }^{113}$.

A descoberta do mundo pela visão continuará no passeio de jeep, quando a experiência infantil remonta a um núcleo ontológico da linguagem, ao processo adâmico de nomear. Chamar o mundo pelo nome não para catalogar e dominar, mas para recebê-lo no mais íntimo de si, fazê-lo existir a partir do lume que se lhe dá por tirá-lo do caos para a luz de um reconhecimento ${ }^{114}$ : "O Menino repetia-se em íntimo o nome de cada coisa." (p. 51); "Todas as coisas, surgidas do opaco"; "Tudo, para a seu tempo ser dadamente descoberto, fizera-se primeiro estranho e desconhecido." (p. 52).

\footnotetext{
${ }^{113}$ O ensaio assim continua: "É quando Guimarães Rosa trabalha justamente com a sensoriedade da própria palavra, que, a um só tempo, "corresponde" à experiência da personagem, "diz" essa experiência, e "convoca" a experiência sensória do leitor, nesse entrelaçamento numa mesma "carne" como diria o filósofo Merleau-Ponti (1975), entre o nosso corpo, o corpo da palavra, e o de uma personagem infantil plenamente imersa no corpo do sertão rosiano" (p. 379)

${ }^{114}$ Em seu estudo sobre o Cântico dos Cânticos, Jean -Yves Leloup comenta este ato de nomear: "Há uma grande diferença entre o nome e a etiqueta. A etiqueta pretende descrever um objeto, enquanto que o nome é um modo de entrar em relação com esse objeto. Nomear alguém é chamá-lo. No livro do Gênesis não se pede a Adão para etiquetar os animais e as plantas, pede-se para que ele os nomeie." (2010, p. 48).
} 
Processo adâmico e infantil, mas também literário, aparentado à poesia, cujo lavor com as palavras não descreve ou representa, mas apresenta, faz ser sob luz outra. O próprio Rosa, falando sobre seu processo com a linguagem, vale-se da metáfora da luz e da imagem, nas quais surpreendemos novamente o campo simbólico sol-visão de nossos "meninos": "... quero voltar cada dia à origem da língua, lá onde a palavra ainda está nas entranhas da alma, para poder lhe dar luz segundo a minha imagem." (LORENZ, 1991, p. 84).

Há lastro aqui, mais uma vez, para a associação entre a criança, o poeta e o pensamento dito "primitivo" ${ }^{115}$, que já tocamos em outros capítulos. Henriquieta Lisboa, ao falar do tema da infância na obra de Rosa, faz tal aproximação "... a própria filosofia matreira dos primitivos, os quais devem o que pensam ao que vêem, tocam e degustam, as fontes ocultas no magma em potencial, o bárbaro e o primevo, tudo isso remonta à infância do autor." (LISBOA, 1991, p. 171); e Marie-José Chombart de Lauwe, estudando os processos de conhecimento das crianças conforme retratados na literatura francesa, constata: "Tanto pelo seu modo de conhecimento sensorial, como pela sua imaginação, a criança foi aproximada ao poeta. Quando se evoca uma forma de pensamento dito "pré-lógico", a imagem do primitivo também se apresenta." (1991, p. 372). A apreensão predominantemente sensorial do mundo, forma de pensamento menos abstrato, aparentado ao mítico, movido pelas pulsões do corpo, atravessa a relação dos "primitivos", infantes e poetas com a palavra. Para os três, manejar a palavra é ato mágico, que traz o mundo à luz, pois a identidade essencial entre o verbo e o que ele representa ainda não se perdeu... não a palavra signo, mas a palavra-coisa, palavracorpo que, pronunciada, é presença ${ }^{116}$. Nesse lugar "originário" e "original", em que algo do que o antropólogo Lévy Bruhl identificou como "princípio de participação"117

\footnotetext{
115 "Desde há muito tempo constatou-se que o funcionamento mental da criança (...) tem pontos análogos ao funcionamento mental do primitivo." (LEEUW, 1940, apud DE LAUWE, 1991, p. 372).

${ }^{116}$ Não é intuito aqui adentrar os vastos estudos sobre a relação da palavra com o poder criador no pensamento mítico-religioso dos mais variados povos antigos ou ditos "primitivos". Já mencionamos Vico que, em sua Scienza Nuova, aventa a hipótese dos homens terem primeiro falado por poesia, impregnando a linguagem de imagens provindas de sua robusta fantasia. (1999, p 153-154). Destacamos como estudo de mais fôlego a obra "Linguagem e Mito", de Ernest Cassirer; apenas uma amostra do caminho que ele persegue: "Este vínculo originário entre a consciência linguística e a mítico-religiosa expressa-se, sobretudo, no fato de que todas as formas verbais aparecem outrossim como entidades míticas, providas de determinados poderes míticos, e de que a Palavra converte-se numa espécie de arquipotência, onde radica todo o ser e todo o acontecer" (2000, p. 64)

117 "É preciso entender, por esta forma de atividade mental nos primitivos, não um fenômeno intelectual ou cognitivo puro ou quase puro, mas um fenômeno mais complexo, onde o que é para nós propriamente "representação" se encontra ainda confundido com outros elementos de caráter emocional ou motor, colorido, penetrado por eles e implicando, por consequência, numa outra atitude com relação aos objetos representados" (BRUHL, 2015, p. 20)
} 
rege o pensamento, os seres e as coisas aparecem irmanados por outras diversas relações e as dimensões emotivas, melódicas e imagéticas que impregnam o sentido e o sentir transpõem-se para a linguagem. Vemos o ato de nomear do nosso Menino atravessado, assim, por intensa carga sensorial e poética, em rimas, assonâncias, aliterações, personificações, metáforas: "A poeira, alvissareira (...) o velame-branco, de pelúcia."; "A arnica: em candelabros pálidos"; "As pintangas e seu pingar (...) as flores em pompa arroxeadas de canela-da-ema"; "Essa paisagem de muita largura, que o grande sol alagava" (p. 52). É a "descoberta do mundo" em conjunção com a descoberta da linguagem. Note-se, porém, que ela se dá apenas em seu aspecto luminoso. Se no plano físico o menino já desceu do avião, e o passeio de jeep se dá em terra, no plano psíquico ele permanece no alto, sua experiência terrena não tem ainda duas faces, é feita apenas de céu: "E em sua memória ficavam, no perfeito puro, castelos já armados (...) Ele estava nos ares". (p. 52)

Exatamente na metade do conto, isto é, na última metade da parte III (lembrando que temos cinco partes, ao todo), se dará uma segunda "descoberta", reviravolta do enredo que divide o conto e, ao mesmo tempo, o mundo do Menino. Tal divisão começa à mesa do almoço, entre o mundo infantil e o mundo adulto, desdobrada na oposição natureza/cultura; aqui se sobrepõem a conversa dos adultos - O Tio, a Tia, os engenheiros a falar sobre a grande cidade -, e o pensamento do Menino, sôfrego de rever o peru: "Da sala, não se escutava o galhardo ralhar dele, seu grugulejo? Esta grande cidade ia ser a mais levantada no mundo. Ele abria leque, impante, explodido, se enfunava..." (p. 52).

Sabemos, seja pelas circunstâncias temporais e geográficas em que se situa o conto, seja por depoimento do próprio autor ${ }^{118}$, tratar-se, aqui, da construção de Brasília. Essa mudança de paisagem na obra rosiana que comparece em Primeiras Estórias, com uma modernização urbana que invade, por vezes com força agressiva e ameaçadora, o sertão, foi explorada sob diferentes perspectivas pela crítica ${ }^{119}$. Vislumbramos facilmente o paralelo de uma tríade sertão-primevo-infância em oposição a cidade-moderno-adulto, porém veremos que não é tanto uma dinâmica de

\footnotetext{
${ }^{118}$ Em carta aos pais, Rosa relata sua segunda visita à cidade de Brasília, observando a mudança da paisagem, já com menos bichos em relação à primeira vez que lá esteve. Descreve, igualmente, a aparição matinal do tucano que recria no conto "Os Cimos" (ROSA, V.G. 2014, pp. 293-294)

${ }^{119}$ Ana Paula Pacheco a aborda no primeiro capítulo de seu Lugar do Mito (2006, pp. 25-41) e José Miguel Wisnik, em ensaio sobre o conto "Famigerado", toma "As margens da alegria" para na dicotomia sertão-cidade desvelar a persistência de um no outro, lendo a mudança e modernização mais como enigmática do que nostálgica ou apologética $(2002,178-180)$
} 
substituição/eliminação da primeira pela segunda, mas uma tensão complexa que se estabelece entre elas ${ }^{120}$, com traços de uma refletindo-se por vezes na outra, valores "qualitativos" comumente atribuídos - uma natureza "benéfica" e um "mundo maquinal" maléfico, o sertão e a infância "primitivos", "inferiores" diante da potência urbana e adulta - que serão realocados ou invertidos.

Notamos, já nesta cena do almoço, uma oposição entre os interesses infantis, no prazer gratuito da contemplação da natureza, e os interesses econômicos e políticos do mundo adulto, no comprazimento algo ufano por ver nascer em seu país tão distinta cidade; oposição, todavia, não absoluta, pois um ponto de contato se faz visível: tanto o peru quanto a cidade são admirados por seu caráter "superlativo" e "agressivo", o peru "impante", "explodido", crescido em altivez, e a cidade que seria "a mais levantada no mundo". ${ }^{121} \mathrm{O}$ próprio alumbramento do Menino com o peru não se dera apenas pela beleza do bicho, mas por sua majestade, sua postura altiva que guarda também algo de orgulho e poder, não sem certos traços de violência; o peru "lhe dava as costas" para ser admirado, seu movimento de raspar as asas no chão é "brusco, rijo", sua grandeza é "ríspida", e ele é "colérico". Neste lugar infante, porém, em que não se tem, ainda, a experiência da dualidade, a violência não atinge o Menino na chave da crueldade ou da morte, mas na beleza de sua força e potência. Mais adiante, adquirida a consciência moral que acompanha a dualidade e descoberto "o possível de outras adversidades", essa mesma violência agora admirada o confundirá, quando o segundo peru se aproximar para bicar a cabeça degolada do primeiro, descortinando, no cerne da natureza boa e bela, um núcleo igualmente de ódio e destruição, paradoxo difícil para seu "pensamentozinho ainda na fase hieroglífica".

Retornando ao enredo, na ânsia por reaver o prazer da visão do peru, que é já alguma experiência de desejo, portanto, de falta ${ }^{122}$, "Sôfrego de o rever", o Menino deixa a mesa, apenas para se deparar com a falta maior, última e definitiva: "Não viu:

\footnotetext{
${ }^{120}$ A pergunta de Riobaldo a seu interlocutor formula esta mesma tensão sertão-cidade, em chave hipersintética: "[...] cidade acaba com o sertão. Acaba?" (2005, p. 183).

${ }^{121}$ A correlação da potência da cidade à do peru não deixa de guardar certa ironia, uma vez que este, por mais crescido e altivo, "o peru para sempre", é morto no momento seguinte, o que pode levar-nos, por analogia, a prever que, por mais "levantada" que seja, a cidade não está a salvo de fim semelhante... Em se tratando do centro de poder político, talvez se lhe vislumbre mais uma "morte moral" do que propriamente física. Em todo caso, coloca-se sob perspectiva ao mesmo tempo da potência e da transitoriedade tanto o mundo da natureza quanto o das "máquinas", rompendo-se, assim, com uma visão dicotômica entre eles.

122 "...a descoberta do Menino revela-se, a um só tempo, a descoberta de que deseja e que, portanto, é incompleto (...)", escreve a respeito do mesmo conto Ana Martins Rodrigues de Moraes (2007, p. 81)
} 
imediatamente. (...) E - onde? Só umas penas, restos, no chão. - "Ué, se matou. Amanhã não é o dia de anos do doutor? Tudo perdia a eternidade e a certeza; num lufo, num átimo, da gente as mais belas coisas se roubavam." (p. 52). Experimentar a morte é ganhar a consciência do tempo, sair da eternidade para os domínio de Cronos em sua face devoradora que nos impõe a dualidade, o mundo com duas margens, existência e não existência, separadas por não mais do que "um lufo, um átimo"; e onde antes havia certeza e segurança, o hiato das primeiras perplexidades e indagações: "Como podiam? Por que tão de repente?" (p. 52). Opera-se um corte na relação da criança com o tempo, imiscuindo na sua vivência absoluta do presente a preocupação com a finitude e o futuro, instaurando a avidez por extrair o máximo dos momentos de prazer: "Soubesse que ia acontecer assim, ao menos teria olhado mais o peru - aquele." E nos perguntamos se teria sido possível "olhar mais"... Com mais intensidade? Mais do que toda a potência visual com que o peru já o atingira? Ou por mais tempo? E por quanto tempo teria sido suficiente, diante da perspectiva da morte? São as angústias existenciais universais, insolúveis, com as quais nosso Menino se depara, ele, que "no grão nulo de um minuto, recebia em si um miligrama de morte" (p. 53). O tempo se impõe implacável até para arrancá-lo do luto, com os adultos imediatamente buscando-o para irem até o local que estão transformando em cidade.

A quarta (IV) parte é diametralmente oposta à primeira (I), o Menino agora envelhecido, não mais fremente de alegria, "grave, num cansaço e numa renúncia à curiosidade (...)" (p. 53) e também à terceira (III), todas as imagens do passeio de jeep embotadas pela "circuntristeza", perdendo-se na linguagem a carga sensorial e poética do instante adâmico: a "paisagem de muita largura, que o sol alagava" (p. 52) reduziuse a "o um horizonte" (p. 53), " o velame-branco, de pelúcia" (p. 52) tornou-se "o velame-do-campo apenas uma planta desbotada" (p. 53), a poeira, de "alvissareira" (p. 52), não passa de algo que enche o ar. Neste momento, em que a criança apercebe-se de uma outra lógica que governa o mundo, em desacordo com seu sentir, toda a harmonia inicial desemboca na tensão entre tentar compreender e adequar-se à moral adulta, "Teria vergonha de falar do peru. Talvez não devesse, não fosse direito ter por causa dele aquele doer, que põe e punge, de dó, desgosto e desengano" e validar o que sente como verdadeiro dentro de sua própria moralidade: "Mas, matarem-no, também, parecia-lhe obscuramente algum erro" (p. 53). O medo do "possível de outras adversidades, no mundo maquinal, no hostil espaço", se confirmará quase de imediato, no lugar onde se prepara o aeroporto. Lá, não só o mundo maquinal se impõe com 
virulência sobre o mundo natural, no trânsito de "compressoras, caçambas, cilindros, o carneiro socando com seus dentes de pilão, as betumadoras" (p. 53), mas novamente a lógica utilitária sobre a admiração contemplativa, os fortes sobre os fracos, a morte sobre a vida: como se o mundo fosse um brinquedo na mão dos homens, para fins de simples demonstração, uma vez que a Tia indaga como haviam cortado ali o mato, a derrubadora atinge com lâmina espessa, "à espécie de machado" (não muito diferente do instrumento que provavelmente decapitou o peru), uma árvore à borda da mata, "fresca, de casca clara...". Desta vez, em lugar do mero "desaparecer no espaço" do pássaro, o Menino presencia a morte da árvore, e, imerso em sua relação sensorial com o mundo, é com todo o seu corpo que ele a vive, o que ele vê e ouve o atravessa, o tremor e queda da árvore o estremecem: "... e foi só o chofre: ruh..."; "Trapeara tão bela. Sem nem se poder apanhar com os olhos o acertamento - o inaudito choque - o pulso da pancada. O Menino fez ascas. Olhou o céu - atônito de azul. Ele tremia. A árvore, que morrera tanto" (p. 54). A linguagem aqui também se faz sensória, e recebemos, nós leitores, "o inaudito choque, o pulso da pancada", com as consoantes plosivas "t", "k", "p", "d" a nos tremer e derrubar igualmente.

A viagem de aprendizagem do protagonista, se a pudéssemos desenhar, se pareceria, até aqui, a uma "montanha russa", uma parábola que ascende em êxtase, iniciada na viagem de avião (parte I), subindo sempre com a descoberta do peru e primeiro passeio de jeep (partes II e III). Quando atinge o cume, dá-se a queda brusca com a morte do peru (fim da parte III), e continua descendente com o novo passeio de jeep coroado pela morte da árvore (parte IV). A quinta (V) e última parte realiza operação exponencial desta experiência, desdobrando sequencialmente o movimento da parábola, emendando suas ascensões e quedas que, embora menos intensas, se darão em espaço de tempo muito mais curto, emolduradas por dinâmica temporalmente equivalente, do "cair do dia" e "subir da noite" que é "sempre e sofrido assim, em toda parte" (p. 54), como é sempre e sofrido assim, para a condição humana, viver alternâncias quase imediatas entre céu e inferno. Malgrado a tristeza e falta do peru, o Menino retorna ao terreirinho e eleva-se subitamente em alegria com a visão da ave, apenas para decair decepcionado por ser este outro peru, não tão belo quanto o primeiro; mas o consolo de sua presença é, de toda forma, nova elevação, que continua a subir por ele adivinhar uma "simpatia companheira e sentida" do novo peru quando este se aproxima da cabeça degolada do antigo; nova queda: o gesto revela-se violência, ódio que move a ave a bicar, feroz, aquela outra cabeça. Podemos pensar que Rosa oferece 
aqui outra balança, ao lado daquela sentida inicialmente como "infidelíssima" pelo Menino, cujo sentido se refaz a cada movimento na alternância contínua de seu sobe e desce.

Descobrir uma violência intrínseca à natureza é demais para a compreensão do "pensamentozinho ainda na fase hieroglífica" (p. 54) do Menino, e escurece por completo o mundo, revelado na sua face negra, obscura, imponderável, grande demais, até cindir o próprio conto por parágrafo de uma única palavra,"trevava". A alquimia linguística de Rosa, que aqui transmuta substantivo em verbo, transforma igualmente as categoria da vida, e nos dá nova dimensão da experiência negativa radical que parece encerrar o movimento de ascensões e quedas em depressão definitiva. A palavra "voava", que inicia, contudo, o parágrafo seguinte, rima com a anterior, fazendo ecoar nas trevas a luz, na depressão a ascensão, e, em um impulso nos lança nos ares novamente, sintetizando toda a aprendizagem da viagem, que é a da própria existência, no deslumbre com a Beleza e entrega à Alegria permeados pela consciência de sua fugacidade:

"O Menino não entendia. A mata, as mais negras árvores, eram um montão demais; o mundo.

Trevava.

Voava, porém, a luzinha verde, vindo mesmo da mata, o primeiro vaga-lume. Sim, o vaga-lume, sim, era lindo! - tão pequenino, no ar, um instante só, alto, distante, indo-se. Era, outra vez em quando, a Alegria." (p. 55)

O vaga-lume que vem "mesmo da mata" escura, com sua luzinha verde remetendo-nos à esperança, ecoa as reflexões de Riobaldo, em Grande Sertão: Veredas, acerca da dualidade da existência, o "mundo misturado" que tanto o inquieta: "A vida é ingrata, no macio de si. Mas transtraz a esperança mesmo do meio do fel do desespero" (2005, p. 237). O Menino realiza em sua experiência infantil de "encontro com a realidade" uma aprendizagem não muito diferente da proferida pelo jagunço. Cabe, no entanto, ressaltar que, ao longo do conto, esse encontro se fez de duas vertentes algo distintas em que se delineiam tensões e oposições. Uma diz respeito a questões existenciais humanas, metafísicas, figurada na oposição eternidade/finitude. É quando, como vimos, a vivência infantil de narcisismo primário, de ilusão de 
onipotência, sentimento de eternidade e completude, por ignorar-se ainda a lei da dualidade, cai por terra, e o mundo revela-se em suas ambivalências, em sua impermanência; o encontro com a morte como parte inexorável da vida instaura para o Menino, e para todos nós, a falta, o medo, a insegurança de saber que "entre o contentamento e a desilusão, na balança infidelíssima, quase nada medeia" (p. 53). A outra vertente diz respeito a questões morais e formas de relação com o mundo, e nela a lógica adulta aparece contraposta à infantil. Os adultos do conto, mesmo tratando a criança com toda amabilidade, têm com o mundo uma relação de apropriação e dominação, em que impera a lógica utilitária: a vida do peru só tem serventia enquanto alimento para a mesa de aniversário do doutor, e as árvores, empecilho à "fabricação" do chão do aeroporto, de nada valem.

Percebemos que, enquanto o aprendizado da primeira se faz necessário - e segue seu curso até o final do conto, quando o Menino sente que "alguma força, nele, trabalhava por arraigar raízes, aumentar-lhe alma" (p. 54) - o da segunda permanece em zona nebulosa, a atitude adulta parecendo à criança "obscuramente algum erro" ${ }^{123}$. Anita Martins Rodrigues de Moraes (2007) aponta, tendo em mente a tese de Adorno e Horkheimer n'A dialética do esclarecimento, que, em Primeiras Estórias, há uma associação entre conhecimento e amor radicalmente avessa à analogia operada no Ocidente, particularmente a partir do século XVI, entre conhecimento e dominação. Lembremos que, segundo os dois pensadores, o projeto do esclarecimento foi $\mathrm{o}$ desencantamento do mundo; dissolvendo os mitos e substituindo a imaginação pelo saber, vencia-se a superstição com o objetivo de "livrar os homens do medo e investilos na posição de senhores." (1985, p. 17). E os próprios autores, algo dramaticamente, na primeira página já anunciam: "Mas a terra totalmente esclarecida resplandece sob o signo da calamidade triunfal" (1985, p. 17); porque a ciência teria operado, em seu afã de esclarecimento, uma associação entre conhecimento e dominação, de forma que o ato de conhecer equivaleria a ter poder e controle sobre o objeto a ser conhecido. Nessa dinâmica, instaura-se a dicotomia sujeito/objeto, e não mais "somos com" as coisas, mas as coisas são "para nós", o sujeito detendo toda a atividade, os objetos e seres desprovidos de essência particularizante, à mercê de sua manipulação: "O que os

\footnotetext{
${ }^{123}$ Em Campo Geral, Miguilim, diante do mundo adulto, da tristeza da mãe, do esforço em equacionar categorias morais ou estéticas, tem essa mesma percepção: "No começo de tudo tinha um erro - Miguilim conhecia, pouco entendendo" (2001, p. 29)
} 
homens querem aprender da natureza é como empregá-la para dominar completamente a ela e aos homens" (1985, p. 17).

Ora, a viagem de nosso menino foi atravessada por essas duas vertentes de aprendizado, mas vemos que elas não são assimiladas da mesma forma. A criança rosiana, no confronto com a realidade, não "desencanta o mundo"; aprende, sim, sobre a finitude da vida, seu caráter de impermanência, mas não incorpora a equação "conhecimento = dominação" às suas atitudes, antes mantém com os seres e as coisas uma relação de proximidade, comunhão, empatia ${ }^{124}$. A morte do peru e da árvore é para o Menino dor real; vê os seres e as coisas na particularidade que os dignifica, os torna únicos e insubstituíveis - as descrições de sua visão do peru e da árvore o reafirmam e, mais adiante, a reação ao "novo" peru que surge, trazendo consolo mas não substituindo o primeiro, também. Por isso ele adivinha, na atitude dos adultos, um "erro". Aqui, como em outros contos que analisamos, concebe-se a existência infante como detendo maior potência em relação à dos adultos. Se a atitude "esclarecida" procurou conhecer para dominar, não foi justamente para livrar-se da insegurança, da fragilidade do homem diante de forças maiores do que ele, cuja figuração extrema encontra-se na finitude, na morte? Não terá sido para livrar-se desta dor, do insuportável de estar à mercê da impermanência e do mistério que o homem "desencantou" o mundo, instaurando a dicotomia sujeito/objeto? Se assim o for, o que o infante consegue enquanto síntese de aprendizagem no confronto com a finitude ultrapassa em muito aquilo de que o adulto foi capaz; o vemos tanto ao final deste conto, em que se abraça a Alegria mesmo que provisória, quanto no da novela "Campo Geral", quando Miguilim, após inúmeros sofrimentos, inclusive a morte do irmãozinho querido e

\footnotetext{
${ }^{124}$ Neste aspecto, nossa análise diverge da de Ana Paula Pacheco que, em seu trabalho Lugar do Mito narrativa e processo social nas Primeiras Estórias de Guimarães Rosa (2006), vê uma "tônica menos vibrante" no primeiro e último conto de Primeiras Estórias por conta da moldura histórica, o triunfo maquinal da construção da cidade, criar um "problema para a visão mitologizante dos contos", que colocaria em xeque o anseio de refazer o mundo melhor, fazendo a visão cosmogônica "recuar a um lugar contraditório, de cosmogonia privada ou de idealismo individual, ainda que com Menino alegórico" (p. 40). Para nós, conforme a exploração das duas vertentes de aprendizagem no "encontro com a realidade", do conto emerge uma postura crítica juntamente com outra forma de se relacionar com a realidade maquinal que se instaura. Longe de uma "cosmogonia privada ou idealismo individual" do Menino - não coerente com seu caráter alegórico -, a associação entre conhecimento e amor, oposta à postura "esclarecida", e a afirmação da vida como experiência de trânsito entre as "duas margens" da alegria e da dor, se sustenta, para nós, como universal. Depende, inclusive, de uma realidade violenta e agressiva, a força de afirmação da alegria não apenas neste conto, mas em diversas passagens da obra rosiana. O crítico Alfredo Bosi ressalta a presença das agruras da realidade sertaneja na obra rosiana não como criadora de contradição nos enredos esperançosos, mas servindo à "perspectiva da providência", segundo a qual "Em todas as situações, e sobretudo nas mais espinhosas, haveria sempre uma ponte de trânsito livre, algum momento, desejado e indeterminado, em que sobrevêm a mudança." (2003, p. 39).
} 
suicídio do pai, coloca os óculos do doutor e pode olhar para tudo, abarcando na realidade que o circunda tanto a geografia física quanto a humana, e exclamar "O Mutum era bonito! Agora ele sabia." (2001, p. 152).

Há um pequeno artigo de Freud, "Sobre a transitoriedade" (1916 [1915]), em que reflexões semelhantes emergem. O psicanalista, passeando em dia de verão na companhia de dois amigos, observa que um deles contempla as belezas da natureza sem conseguir extrair delas qualquer alegria, perturbado pelo pensamento de que toda ela, bem como toda beleza humana ou das coisas que os homens podem criar, está fadada ao desaparecimento, presa da efemeridade do tempo. "Tudo aquilo que, em outra circunstância, ele teria amado e admirado, pareceu-lhe despojado de seu valor por estar fadado à transitoriedade" (p. 345), escreve o psicanalista, refletindo, porém, que a transitoriedade deveria equivaler antes a aumento de valor das coisas do que diminuição, sendo impossível que interferisse na alegria que delas extraímos: "A limitação da possibilidade de uma fruição eleva o valor dessa fruição" (p. 345), e conclui que o amigo só poderia ter a experiência inversa por estar tomado de uma antecipação de luto pela morte desta beleza e revolta contra este mesmo luto.

Haveria, assim, algo de "infantil" - não no sentido rosiano, mas de imaturidade emocional - em despojar de valor aquilo que sabemos passivo de ser perdido, recusando a vivência do luto, e, ao contrário, de maturidade e coragem na reafirmação da beleza e entrega à alegria malgrado a certeza da finitude. Nessa perspectiva é que afirmamos a potência de nosso Menino e de Miguilim e a debilidade da postura adulta que esvazia de valor o que é efêmero, no caso do conto mantendo com a natureza uma relação de dominação e reificação.

Decair do paraíso, perder a eternidade, saber que a condição própria da existência é a mudança, a impermanência, descobrir a violência do mundo e, ainda assim, continuar a existir em comunhão com o outro, em identificação com a natureza, permeável à Beleza e Alegria, ao alumbramento; não deixar de "ser com" aquilo que, sabe-se, pode durar menos de um segundo, uma luzinha frágil e verde como a esperança, "no ar, um instante só, alto, distante, indo-se" (p. 55) e que, com sua partida, abre-nos a falta, dor e desalento, também eles, provisórios. A "Alegria" rosiana, segundo imagem que o título do conto nos dá, não é a margem oposta à tristeza - ela é o próprio rio, de fortes águas, que não param. Navegar nessas águas, tocando ora uma ora outra margem, sem perder a afirmação da vida, é o aprendizado do Menino. 


\section{3 "Outra era a vez"... das margens aos cimos}

Imagem espelhada do primeiro, segundo a estrutura do livro Primeiras Estórias $^{125}$, o último conto, "Os Cimos", repõe o mesmo Menino em viagem à mesma cidade, porém anunciando-nos desde o início que "outra era a vez", o que não apenas marca passagem temporal a nos apresentar a personagem mais velha, mas mudança na experiência da viagem em si. As partes do conto, em vez de algarismos romanos, trazem agora subtítulos, e poderíamos, quiçá, ver nesta diferença a passagem do "pensamentozinho ainda em fase hieroglífica" - os algarismos romanos figurando sequência de experiências ainda não nomeáveis - para o desenvolvimento da subjetividade e reflexão infantil tão pungentes no último conto, que viabilizam a expressão do vivido em signos linguísticos, os subtítulos em questão. O primeiro deles, "O inverso afastamento" já nos revela o caráter de "imagem invertida" próprio do espelho; O que era ascensão, agora é descida, o que principiara como senso de eternidade, segurança e onipotência, partirá da iminência da finitude mais terrível: a viagem, longe de o entusiasmar, encerra medo e desconfiança, pois o Menino sabe que o afastam da mãe por ela estar doente. E tudo se inverte: a bondade dos adultos revelase falsa, ele adivinha nela a tentativa de disfarce da apreensão que também os toma, intuindo as "máscaras sociais" que compõem o jogo da existência adulta: "Também, todos, até o piloto, não eram tristes, em seus modos, só de mentira no normal alegrados?" (p. 225); não só não olha as nuvens, outrora de "amontoada amabilidade", como, por detrás delas, na claridade do céu, pressente "peixes negros", "lombos e garras" (p. 226); e seu antigo senso de segurança, que o extrovertia em curiosidade e entrega ao mundo, "assim um crescer e desconter-se" (p. 49), agora o faz dobrar sobre si, para dentro e para trás: "E o Menino estava muito dentro dele mesmo, em algum cantinho de si. Estava muito para trás. Ele, o pobrezinho sentado" (p. 225).

O início de ambos os contos se apresenta, portanto, como imagens invertidas: no primeiro, a criança na plenitude da alegria luminosa, no segundo, parte-se do abismo da falta e do medo. Mas a analogia se estende pelo movimento que atravessa os contos do início ao fim e, se é válida a máxima rosiana encontrada em prefácio de Tutaméia ,"Se viemos do nada, é claro que vamos para o tudo" (1969, p. 12), as "margens" da

\footnotetext{
${ }^{125}$ Seus vinte contos podem formar dez pares "espelhados" pelo vigésimo primeiro conto, "O espelho", situado exatamente na metade do livro.
} 
alegria, aprendizado da dualidade e efemeridade, às quais o Menino teve de descer, serão agora "os cimos" aos quais se elevará: do medo diante da finitude para a descoberta de outras dimensões de si e do mundo, notadamente de uma dimensão de eternidade dentro da própria temporalidade, chegando até à epifania transcendente que anula tempo e espaço, quando todas as instâncias e personagens que fizeram parte de suas vivências subjetivas e objetivas se encontrarão "no mesmo instante só".

Como em muitos ritos iniciáticos, o Menino é arrancado do seio materno para universo predominantemente masculino, afastado da mãe e na companhia apenas do Tio. Mas a Tia lhe dá, para levar consigo, o "bonequinho macaquinho" de calças pardas e chapéu vermelho emplumado, o qual, mais do que "miúdo companheiro", será para ele suporte valioso em seu processo de subjetivação. Como um duplo, em que pode projetar sentimentos e situações vividas, o macaquinho "tão pequeno, sozinho, tão sem mãe", que "iria conhecer do mesmo jeito o tamanho daquelas árvores, da mata, pegadas ao terreiro da casa" (p. 226) e adormece "feito um muito velho menino" (p. 227) servirá para a criança viver, em dimensões possíveis, a tristeza e a perda; enquanto a ameaça de morte da mãe as traria grandes demais para ele conceber, o chapeuzinho festivo do macaquinho, com sua carga simbólica de alegria destoante do momento vivido, ele consegue dispensar; arranca-o e o joga fora, ainda no avião, tornando-se sujeito agente da perda, em vez de sofredor impotente. Impossível não enxergar, aqui, uma analogia com o primeiro ato da brincadeira do fort- $d a^{126}$, que Freud observou seu neto realizar. Com um ano e meio, o menininho adorava atirar objetos e brinquedos sob a cama, fazendo-os "ir embora", fort, palavra que pronunciava como expressivo "o-o-o-ó". Quando apanha um carretel com linha, se vê a brincadeira completa: "o-o-o-ó", ele o lança por entre as cortinas do berço, fazendo-o desaparecer; $d a$ (ali), ele o puxa de volta para si, fazendo-o retornar. Freud, em um primeiro momento, interpreta o jogo como a renúncia à satisfação instintual que a criança efetuara ao deixar a mãe ir embora, nos momentos em que esta se ausentava (não nos escapa aqui o paralelo do Menino afastado da mãe na viagem), da qual compensava-se encenando ele próprio o desaparecimento e retorno dos objetos a seu alcance. O psicanalista observa, contudo, que há igualmente satisfação em apenas "fazer desaparecer" os objetos, e supõe que, por mais

\footnotetext{
${ }^{126}$ Segundo nota da tradução em português (FREUD, 1920, p. 26), a tradução do alemão para o inglês traz "fort" como "gone", particípio passado do verbo "to go", "ir", "partir", correlato ao adverbio "embora", em português, que normalmente empregamos na expressão "ir embora", enquanto "da" significaria "ali".
} 
desagradável que seja a experiência da perda, a criança, ao transformá-la em jogo, sai da situação passiva para assumir papel ativo. Esta elaboração tão primária, de perda e reparação, que se nos impõe desde tenra idade, jamais nos abandonará, porque em seu cerne estão os grandes mistérios da existência que se entrelaçam e determinam mutuamente: a inexorabilidade do tempo, a impermanência, a finitude - das coisas, dos seres e de nós mesmos. O sujeito que com eles se depara tem ainda de se haver com a incompletude, a falta, com a cisão entre seu desejo e a realidade, e a aceitação de forças maiores do que ele, para além de seu controle. Este será o centro da experiência de nosso Menino, e é como menino, como criança, que ele a atravessará.

Estamos diante de um infante cujo pensamento já ultrapassou a fase hieroglífica e tecerá reflexões mais profundas quando confrontado com o imponderável, a doença da mãe e o sofrimento que "formavam avesso - do horrível do impossível" (p. 225). Assim, ainda no avião, ele transita da perspectiva objetiva, do "móvel mundo", para a subjetiva, do "móvel homem", e a percepção de um "erro" inerente à existência, oposta à de uma "harmonia prévia, benfazeja", o expulsa de um fluir processual típico da primeira infância, dando lugar à perplexidade diante das circunstâncias sempre cambiantes que escapam ao controle: "Tudo era, todo-o-tempo, mais ou menos igual, as coisas ou outras. A gente, não ${ }^{127}$. A vida não parava nunca, para a gente poder viver direito, concertado?" (p. 225). O desejo de parada frustrado pela consciência da inexorabilidade do tempo retorna em suas reflexões noturnas, quando, já na casa, apercebe-se da noite que caminha para o outro dia, e conclui: "Ainda que a gente quisesse, nada podia parar, nem voltar para trás, para o que a gente já sabia, e de que gostava." (p. 227) Como retorna, intensificada, a angústia pela finitude já experimentada no primeiro conto, que leva a criança a perder a fruição de um presente absoluto, arrependida de sua espontaneidade e despreocupação, como se, pela inconsciência da possibilidade do fim, toda experiência passada se revelasse insuficiente, tivesse de ter sido vivida "mais" ou "melhor": "Soubesse que ia acontecer assim, ao menos teria olhado mais o peru", pensa o Menino n“As margens da alegria”, e, agora: "Soubesse que um dia a Mãe tinha de adoecer, então teria ficado sempre junto dela, espiando para ela, com força, sabendo muito que estava e que espiava com tanta força, ah." (p. 226).

\footnotetext{
${ }^{127}$ Novamente temos eco, nesta passagem, das reflexões de Riobaldo em Grande Sertão: Veredas: "O mais importante e bonito, do mundo, é isto: que as pessoas não estão sempre iguais, ainda não foram terminadas. Afinam, ou desafinam. Verdade maior, é o que a vida me ensinou" (2005, p. 39)
} 
Inicia-se, aqui, um processo que se desdobrará ao longo do conto: é o germinar da consciência reflexiva, um alargamento da subjetividade em sentimentos e pensamentos, que operará mudança radical na forma da criança se relacionar consigo mesma e com o mundo. Já na primeira parte o vislumbramos, no desejo de proximidade com a mãe que guarda, também, "inverso afastamento", pois, enquanto é alijado fisicamente de sua presença, o Menino descobre uma outra lei para além da presença física, que o torna ainda mais próximo da mãe: "Do jeito feito agora, no coração do pensamento. Como sentia: com ela, mais do que se estivessem juntos, mesmo, de verdade" (p. 226). Seu ápice se dá, porém, no segundo momento, intitulado "Aparecimento do pássaro" quando, na madrugada da noite que passou quase toda em claro, em um entre-lugar, nem sono nem vigília, ele subitamente "recebia uma claridade de juízo (...) Quase como assistir às certezas lembradas por um outro (...); feito ele estivesse podendo copiar no espírito ideias de gente muito grande" (p. 227). Esse vislumbre recebido, à espécie de reminiscência platônica ${ }^{128}$, é tecido de reflexões surpreendentemente profundas para uma criança - ainda que em uma linguagem maravilhosamente infantil - a respeito das questões existenciais que já mencionamos, o desacordo entre subjetividade e objetividade, o imponderável e o controlável, a incompletude, o "mundo misturado", a impermanência e finitude, motivos pelos quais ele conclui que:

"[...] a gente nunca podia apreciar, direito, mesmo, as coisas bonitas ou boas, que aconteciam. Às vezes porque sobrevinham depressa e inesperadamente, a gente nem estando arrumado. Ou esperadas, e então não tinham gosto de tão boas, era só um arremedado grosseiro. Ou porque as outras coisas, as ruins, prosseguiam também, de lado e do outro, não deixando limpo lugar. Ou porque faltavam ainda outras coisas, acontecidas em diferentes ocasiões, mas que careciam de formar junto com aquelas, para o completo. Ou porque, mesmo enquanto estavam acontecendo, a gente sabia que elas já estavam caminhando, para se acabar, roídas pelas horas, desmanchadas...". (p. 227-228)

\footnotetext{
${ }^{128}$ Já exploramos, no capítulo 2 deste trabalho, a teoria da reminiscência platônica dentro do tema da figuração infantil a partir da imagem das crianças como mais próximas a uma "origem", o lugar inominável de onde viemos e para onde retornamos, e que os fazem ter acesso a "verdades" já vislumbradas, portanto, apenas "lembradas".
} 
Da mesma forma como no entre lugar do sono-vigília se deu a revelação clara de impossibilidade de alegria pura, em chave de angústia existencial, no entre lugar temporal da noite para o dia, "entremanhã", quando o Menino vai para o alpendre "entre o terreirinho mais a mata e o extenso outro-lado" de onde se via o horizonte, se dá a revelação luminosa do voo do tucano dentro da luz do amanhecer, que o elevará da angústia ao êxtase. Novamente por meio da visão de um pássaro a criança experimenta o alumbramento, e não são poucas as associações entre infantes e pássaros na obra rosiana. Para retomar os contos que já percorremos, lembremos, em "Tresaventura", o olhar embevecido de Djá/Iaí para os passarinhos, que eram "só do céu, seu alicercinhos" (p. 175), assim como Nhinhinha, a "menina de lá", terá seu momento epifânico de alegria num dia de chuva em que "os passarinhos cantavam, deputados de um reino", segundo os pais tendo ela "adivinhado passarinho verde" (p. 71); de Brejeirinha, nos "apreparos" para passeio ao riacho, se diz que estava "de alegria ante todas, feliz como se, se, se: menina só ave" (p. 170). Mas temos ainda o "moço muito branco" que, depois de misterioso aparecimento, seguido de outros fatos insólitos na comarca de Serro Frio, igualmente sem rastro se vai, à maneira de pássaro: "Com a primeira luz do sol, o moço se fora, tidas asas" (p. 155), e o Menino Diadorim, para sempre associado a seu passarinho de amor, o Manoelzinho-da-Croa, depois de adulto ainda será em inúmeros momentos referido por Riobaldo em estreita analogia com os pássaros ${ }^{129}$.

É bastante difundida a simbologia dos pássaros como intermediários entre o céu e a terra. Chevalier \& Gheebrant (2008, p. 687) nos lembram que a palavra "pássaro", em grego, foi sinônimo de "presságio" e "mensagem do céu", enquanto no taoísmo os imortais adotam a forma de aves para significar leveza, a libertação do peso terrestre, imagem que dialoga em certa medida com muitas leituras reencarnacionistas a figurarem a alma como um pássaro imortal que, no momento da morte, se liberta da gaiola do corpo. Essa libertação do peso da temporalidade, que os infantes rosianos parecem encarnar, é tema caro ao autor e atravessa sua obra. Em conversa com o crítico Gunter Lorenz, Rosa diz que este escreveu a respeito de Grande Sertão uma frase que lhe proporcionou:

\footnotetext{
129 "Abracei Diadorim, como as asas de todos os pássaros" (ROSA, 2005, p. 57) "Gostava de Diadorim, dum jeito condenado; nem pensava mais que gostava, mas aí sabia que já gostava em sempre. Oi, suindara! - linda cor... (p. 110); "Mas, melhor de todos - conforme o Reinaldo disse - o que é o passarim mais bonito e engraçadinho de rio-abaixo e rio-acima: o que se chama o manuelzinho-da-crôa" (p. 159).
} 
"... mais alegria que tudo quanto já se disse a meu respeito. Conforme o sentido, dizia que em Grande Sertão eu havia liberado a vida, o homem, von der Last der Zeitlichkeit brefreit ${ }^{130}$. É exatamente isso que eu queria conseguir. Queria libertar o homem desse peso, devolver-lhe a vida em sua forma original." (LORENZ, 1991, p. 84)

A vida em sua forma originária e original, que Rosa tanto perscruta, na linguagem e em suas personagens - jagunços, loucos, prostitutas, crianças -, parece estar muitas vezes em um entre-lugar: entre matéria e espírito, imanência e transcendência, som e sentido, conteúdo e forma. Não se resume à realidade objetiva mas tampouco prescinde dela; o caminho que liberta o homem do peso da temporalidade passa necessariamente por ela ${ }^{131}$ (não seria, do contrário, tão abundante a geografia física e tão contundente a materialidade das palavras em sua obra!), faz ponte, irmana esses contrários. Como isomorfo do pássaro, em seu voo no avião, o Menino prefigura nesses dois contos que protagoniza algo dessa ponte entre céu e terra, eternidade e finitude. Nas "margens da alegria", experiência de "confronto com a realidade", queda brusca na descoberta da morte, o mundo com seus seres e coisas perecíveis, tínhamos um pássaro notadamente mais terreno e doméstico, confinado ao terreirinho da casa, se passeando no chão, enquanto "Os cimos" elevam-nos com seu tucano em voo, em "brando batido horizontal", o qual, mesmo quando pousa, o faz perto do céu, na copa dourada das árvores; e vemos, ao final, que o aprendizado da criança será, desta vez, um retorno às "alturas", a um novo senso de eternidade - ao qual se chega por uma via bastante terrena.

O "aparecimento do pássaro" estará misturado à visão da própria luz, seu preâmbulo áureo seguido da explosão solar que rompe o horizonte. Ganha aqui mais potência a imagem que já recuperamos da visão como órgão solar e, como no primeiro conto, o narrador a reforça textualmente: "Seria de ver-se: grande de enfeites, o bico semelhando flor de parasita."; "E, de olhos arregaçados, o Menino, sem nem poder segurar para si o embrevecido instante, só nos silêncios de um-dois-três."; "O Tio, também, estava de fazer gosto por aquilo: limpava os óculos"; "E o tucano, o vôo, reto,

\footnotetext{
130 "Liberto do peso da temporalidade", citado em alemão por Guimarães Rosa.

${ }^{131}$ Extremo paradoxo, que ecoava já na máxima de Zé Bebelo: "A gente tem de sair do sertão! Mas só se sai do sertão é tomando conta dele a dentro..." (ROSA, 2005, p. 294-295)
} 
lento - como se voou embora, xô, xô! - mirável, cores pairantes, no garridir; fez sonho. Mas a gente nem podendo esfriar de ver." (p. 228 -229, grifos nossos). É trecho em que a linguagem atinge também "os cimos" da plasticidade descritiva, sua carga poética em cores, luzes e movimentos, rimas, assonâncias e aliterações enlevam-nos juntamente com o Menino: "O alto azul, as frondes, o alumiado amarelo em volta e os tantos meigos vermelhos do pássaro - depois de seu vôo"; "Toda luz era dele, que borrifava-a de seus coloridos, em momentos pulando no meio do ar, estapafrouxo, suspenso esplendentemente." (p. 228); "De lá, o sol queria sair, na região da estrela d'alva. A beira do campo, escura, como um muro baixo, quebrava-se, num ponto, dourado rombo, de bordas estilhaçadas." (p. 229)

O fino trato estético com a linguagem no trecho em questão é, tanto para o Menino quanto para nós, leitores, êxtase com o belo, mas se a experiência não passasse disso, talvez o narrador não dissesse, daquele momento, que "O Menino se lembrava sem lembrança nenhuma. Molhou todas as pestanas" (p. 229). A beleza, sem dúvida, pode comover até às lágrimas, mas a imagem do voo dentro da luz dialoga muito estreitamente com as vivências angustiantes que o protagonista atravessa. Ele, que como "muito velho menino", encontrava-se nos abismos da finitude, da incompletude, da impotência diante do imponderável, as quais tornariam impossível "apreciar, direito, as coisas bonitas ou boas, que acontecem" (ecoando, aqui, o mesmo raciocínio do amigo poeta de Freud já mencionado), será subitamente rejuvenescido, elevado, com esse voo, a uma apreciação plena, embevecida, que desmente sua percepção anterior. A inexorabilidade do tempo, percebida negativamente naquela madrugada, no caminhar inevitável da noite para o dia (simbolicamente, o avanço da doença da mãe ou nosso próprio caminhar para a morte), é revertida para a alegria com a certeza da luz que rompe a escuridão a cada amanhecer.

\subsection{O trabalho do pássaro: tempo, tempo, tempo, tempo... ${ }^{132}$}

O "trabalho do pássaro", subtítulo da parte seguinte, parece ser o de refazer, para o Menino, essa experiência do Tempo; Cronos, comparecendo em seu aspecto

\footnotetext{
${ }^{132}$ Diz o refrão de Caetano Veloso em sua "Oração ao tempo". Nela, para além do tempo cronológico e do cíclico, circular, também se vislumbra, ao final, um tempo fora do tempo: "E quando eu tiver saído, /para fora do teu círculo [...]/ não serei, nem terás sido [...]/ Ainda assim acredito / ser possível reunirmonos / tempo, tempo, tempo, tempo / num outro nível de vínculo [...]".
} 
mecânico inclusive, com o Tio que "media tudo no relógio" e tornando o surgimento do pássaro e o romper do dia um balé precisamente cronometrado: "Esperava o tucano, que chegava, a-justo, a-tempo, a-ponto, às seis e vinte da manhã", que ficava "só os dez minutos" antes do "pingado meio-instante em que o sol arrebolava redondo do chão; porque o sol era às seis-e-meia" (p. 231) revela igualmente sua face cíclica, em que à chegada e partida seguir-se-ão, sempre, nova chegada e partida, rompendo com a percepção de um fim inexorável e definitivo. A alternância de sentimentos já vivida n"As margens da alegria", dor com a morte do peru e alegria temporária, "outra vez, em quando", com o aparecimento do vaga-lume, aqui se desdobra em novas e mais complexas camadas de percepção.

Como no já mencionado jogo do fort-da - não nos escape a descrição do narrador, "o pássaro, seu raiar, cada vez, era um brinquedo de graça" (p. 232, grifo nosso) -, o Menino aprende a deixar ir, na certeza de um retorno que lhe abre, inclusive, a experiência deste hiato, o entre-tempo em meio à partida e o retorno sem o qual nos seria impossível conhecer a esperança; esta, a força que o anima a levantar-se, cada manhã, para ir ao alpendre com os olhos "tardos tontos de sono (...), animoso de amar". O Menino a aprende, inclusive, melhor do que os adultos, que maquinavam maneira de pegar o tucano em gaiola ${ }^{133}$, para lho entregarem, pensando assim consolá-lo, sem compreenderem que ele já sabe a vida e a morte impossíveis de agarrar, e seu único consolo encontra-se em viver o tempo que se renova em belezas, no ir e vir da luz do amanhecer "com, dentro dela, o voo exato", atravessando, inclusive, o intervalo da falta, "O hiato - o que ele já era capaz de entender com o coração" (p. 232).

O movimento cíclico guarda, porém, mais um aspecto que só agora o Menino experimenta - a dimensão de eternidade dentro da temporalidade. O que retorna sempre não pode deixar de se nos afigurar como eterno, vide a alternância do dia e da noite, a dança da natureza, em seu infinito suceder das estações... ${ }^{134}$ É uma das dimensões

\footnotetext{
${ }^{133}$ Comparece aqui, novamente, a oposição entre os pares conhecimento/dominação, norteadora predominantemente da conduta adulta, e conhecimento/amor, mais própria dos infantes rosianos, explorada na primeira parte deste capítulo a partir da teoria do "esclarecimento". É notável também a percepção da criança de que nosso olhar tem a capacidade de reificar o mundo "Não suportava atentar, a cru, nas coisas como são, e como sempre vão ficando: mais pesadas, mais-coisas - quando olhadas sem precauções" (p. 230). A atitude "esclarecida", que desencanta o mundo ao objetificar os seres e coisas, portanto, será rejeitada pelo olhar infantil, que continuará esperando pelo belo, o tucano, que lhe repõe o encanto, ainda que, depois, tivesse de entrar "no vulgar inteiro do dia. O dos outros, não da gente" (p. 230).

${ }^{134}$ Ainda no artigo "Sobre a Transitoriedade", Freud reflete: "Quanto à beleza da Natureza, cada vez que é destruída pelo inverno, retorna no ano seguinte, de modo que, em relação à duração de nossas vidas, ela pode de fato ser considerada eterna." (pp. 345-346)
} 
misteriosas da existência, contida em mitos os mais antigos, como o de Deméter e Perséfone, associado aos mistérios de Elêusis: a vida engendra a morte e a morte engendra a vida, criando uma dimensão de infinitude - palavra tão cara a Rosa - mesmo no mundo da matéria. O símbolo do infinito permeia toda a sua obra - lembremos a lemniscata que encerra graficamente o romance Grande Sertão: Veredas, e que se encontra em todas as ilustrações de Poty que acompanham os títulos de Primeiras Estórias no índice final do livro. Na extensa entrevista ao crítico alemão Gunter Lorenz, Rosa confessa uma relação metafísica com o tempo e a existência, à qual associa a única possibilidade de felicidade humana:

\begin{abstract}
"Mas eu lhe digo uma coisa: apenas alguém para quem o momento nada significa, para quem, como eu, se sente no infinito como se estivesse em casa (...) somente alguém assim pode encontrar a felicidade e, o que é ainda mais importante, conservar para si a felicidade." (LORENZ, 1991, p. 73).
\end{abstract}

É uma dimensão que, ao final do conto, ultrapassa inclusive o movimento cíclico, para constituir-se "eternidade dentro do instante", da qual nosso Menino parece ter tido um vislumbre já em seu primeiro encontro com o tucano, como se, dentro da vivência de Cronos devorador, feita de momentos fugazes, pudesse existir também uma dimensão de movimento que escapa às leis do tempo-espaço para suspender-se na infinitude: "Mas feito se, a cada parte e pedacinho de seu voo, ele ficasse parado, no trecho e impossivelzinho do ponto, nem no ar - por agora, sem fim e sempre." (p. 229, grifos nossos).

O "trabalho do pássaro" dará ainda ao Menino uma tessitura mais complexa do tempo psicológico. Já dissemos que em sua "queda do paraíso" o infante perdeu, entre outras coisas, a dimensão temporal do presente absoluto, sua atualidade extrema liberta seja de passado-saudosismo, seja de futuro-angústia. Mas ganha, com a capacidade de simbolização e complexidade de noções temporais, a possibilidade de deslocar-se do tempo objetivo, externo - os passeios de jeep impondo-lhe um tempo rotineiro que claramente não reconhece como seu, "... a gente entrava no vulga inteiro do dia. O dos outros, não da gente." (p. 230) -, para o subjetivo, evocando a memória do retorno do pássaro, para ele "emoção enviada, impressão sensível, um transbordamento do coração", e de que "podia se servir para consolar-se com, e desdolorir-se, por escapar 
do aperto de rigor - daqueles dias quadriculados" (p. 232). Escapismo na imaginação? Ou mergulho profundo na sua realidade psíquica mais própria, de afirmação da beleza do mundo, da partida e retorno, da espera esperançosa, que ele tanto precisava viver? Distrair-se com a rotina externa, "dos outros", talvez configurasse mais veemente fuga da realidade neste momento. Alargando no tempo cronológico o psicológico, repondo nele o eterno retorno luminoso do tucano, o Menino vai paralelamente tecendo a afirmação de saúde da Mãe, que passa a declarar para si reiteradamente; ela principia com um imperativo de dever, "a Mãe tinha de ficar boa, tinha de ficar salva!" (p. 231), progride a uma afirmação no presente, "A Mãe estava sã e boa, a Mãe estava salva!"135 e culmina em um apagamento completo da doença, a saúde concebida como estado perene, "a Mãe nem nunca tinha estado doente, nascera sempre sã e salva!" (p. 232, grifo nosso). É uma espécie de micro narrativa que o Menino cria para si, impregnada da micro narrativa do "trabalho do pássaro". Se este repôs gradualmente a esperança de retorno do voo dentro da luz e, numa repetição inesgotável, constrói um senso de perenidade, pois o sol e o pássaro sempre retornam, o Menino pode verter a esperança de cura da Mãe em uma realidade já consumada e, por fim, eterna, "nascera sempre sã e salva!". Ambas as narrativas, portanto, permitem ao menino viver, nos acontecimentos determinados cronologicamente, uma dimensão de eternidade, que se consumará na parte final, "O desmedido momento".

\subsection{Para fora das molduras: os cimos da existência}

Terry Eagleton (2006), em suas aproximações entre literatura e psicanálise, nos ilumina ainda melhor este "trabalho do pássaro" de um ponto de vista narrativo. Ele retoma o fort-da de Freud para interpretá-lo não apenas como o domínio simbólico, pela criança, da ausência materna, mas como as primeiras percepções da narrativa, talvez a menor história que seríamos capazes de imaginar: um objeto se perde e em seguida é recuperado, padrão encontrado mesmo nas narrativas mais complexas: uma estrutura original é desordenada e acaba sendo restaurada. Assim, as narrativas emergem como fonte de consolo, jogam com a excitação do nosso desejo diante das perdas por meio do suspense e repetições no enredo, porém estas são toleráveis, uma

\footnotetext{
${ }^{135}$ A forma do pretérito imperfeito, aqui, deve ser atribuída ao fato da fala/pensamento do Menino nos ser transmitida pelo narrador por discurso indireto.
} 
vez que secretamente sabemos que o "objeto perdido" reaparecerá no final; "Fort só tem significações em relação a $d a^{\prime \prime}$. O mesmo expediente narrativo do pássaro possibilitou ao Menino, portanto, reescrever a narrativa da doença da mãe. Eagleton, porém, leva seu raciocínio até o movimento inverso, concluindo que, "uma vez instalados na ordem simbólica", não podemos contemplar nem possuir qualquer objeto, sem vê-lo inconscientemente à luz de sua possível ausência, sabendo que sua presença é, de certa maneira, arbitrária e provisória" (2006, p. 279). Era esse o estado do Menino no início do conto, angustiado com o potencial desaparecimento de tudo, não querendo mais sequer ter brinquedos, pois "enquanto a gente brincava, descuidoso, as coisas ruins já estavam armando assanhação de acontecer: elas esperavam a gente atrás das portas" (p. 226). O salto rosiano, no caso deste conto, será a dimensão de eternidade de que a narrativa do Menino é imbuída e sua elevação final que, como veremos, ultrapassa tempo e espaço, por um instante lhe permitindo romper com o ciclo interminável de presença-ausência, anseio-saciedade ao qual, psicanaliticamente falando, estamos todos fadados.

Não podemos dizer que neste conto o Menino, como Nhinhinha, manifeste os poderes demiúrgicos de materializar pela palavra seus desejos. Mas em sua experiência houve uma concordância entre o retorno certo e preciso do pássaro e do sol, cujo voo luminoso o eleva à certeza de cura, reiteradamente repetida em silêncio para si mesmo, e o retorno, de fato, da saúde da Mãe, que significará, igualmente, seu retorno para casa. Algo invariavelmente permanece no mistério dentro da literatura rosiana, a desafiar nossa petição de certezas ou a tendência a explicar o que nos escapa como mera "coincidência". Como vimos, os infantes, seja por estarem ainda tão próximos do lugar insondável de onde viemos, seja por sua forma de existência aquém das camadas de aculturação, mantêm relação mais íntima com o mistério, o admitem com naturalidade, quando não dialogam diretamente com ele. O Menino, por isso, diante da origem desconhecida do tucano, "Se donde vinha e morava - das sombras do mato, os impenetráveis?"136, nada questiona ou indaga, antes valida que uma parcela do vivido permaneça velada: "Mas o Menino pensava que devia acontecer mesmo assim - que ninguém soubesse. Ele vinha do diferente, só donde. O dia: o pássaro" (p. 231), levando-nos, leitores, a abrir da mesma forma um espaço claro para o que não se explica logicamente no conto: mesmo diante dos dados de realidade, telegramas que tornavam

${ }^{136}$ Notem-se os termos "sombras" e "impenetráveis", a ecoar o campo semântico do mistério. 
gestos e expressões do tio mais apreensivos, o Menino continua a insistir em sua afirmação de saúde da Mãe, e esta de fato se consuma.

O momento final do conto, como mencionamos, reúne em si movimentos coincidentes de "retorno" até o típico desfecho de muitas narrativas, o "retorno" do herói/protagonista a casa. Nele se dará, ainda, outra narrativa de perda e reparação numa sucessão quase imediata: o sumiço do bonequinho-macaquinho e recuperação do chapéu inicialmente descartado, que não deixa de ser significativo: atravessada a perplexidade e a dor, elaborada a angústia da finitude, o duplo em que o Menino se projetava não é mais necessário, e a alegria festiva simbolizada pelo chapeuzinho pode retornar. Coroamento de todas as experiências de "ir e vir", este momento leva ainda a criança a formular uma imagem que lhe ressignifica a falta, a finitude ou a impermanência porque retira-lhes seu caráter de "aniquilamento": ele concebe a existência de uma "outra parte", a nós invisível e inacessível, mas distinta do "sem-fim escuro do mundo", um "lugar" tão real quanto nossa realidade palpável ${ }^{137}$, onde o perdido continua tendo existência, e aonde "as pessoas e coisas sempre iam e voltavam." (p. 233). É como se ele burlasse as regras do fort-da freudiano, suprimindo a angústia do tempo do fort ao fazer, dessa ausência, uma "presença alhures", em algum espaço-mistério.

A apercepção metafísica, que o tira do "caos pré-inicial" ao dar uma forma ao informe da experiência subjetiva ${ }^{138}$, se faz trampolim para o salto, abertura para um "desmedido momento", apoteótico e fugaz como toda epifania soe ser, e que consuma a passagem da eternidade enquanto ciclo/retorno para a eternidade dentro mesmo do instante. O Menino subitamente apercebe-se da "paisagem e tudo, fora das molduras" (p. 233); eleva-se a um "tempo-sobre-tempo", com todas as pessoas, lugares e situações que compuseram seus dias, na distância imaginária e na presença física - a mãe sã, salva e sorridente, o bonequinho macaquinho, o alpendre do terreiro, o jeep aos solavancos, todos os lugares visitados - coincidindo no tempo e espaço, "no mesmo instante só", assistindo ao "sol no renascer e ao voo, ainda muito mais vivo, entoante e existente - parado que não se acabava - do tucano, que vem comer frutinhas na

\footnotetext{
${ }^{137}$ Ainda uma vez, a "existência da não existência", forte na obra rosiana, comparece, aspecto que Paulo Rónai destacou inclusive como unificador dos contos de temas e enredos tão vários de Primeiras Estórias: "O que existe dilui-se, desintegra-se; o que não há toma forma e passa a agir" (2001, p. 19)

${ }^{138}$ Lembremos, ainda uma vez, Antonio Candido, em seu "Direito à literatura", quando advoga que o caráter de "coisa organizada" da obra literária capacita-nos a ordenar nossa própria mente e sentimentos e, portanto, nossa visão de mundo (2011, p. 179)
} 
dourada copa, nos altos vales da aurora, ali junto de casa. Só aquilo. Só tudo." (p. 234, grifos nossos).

"Esta é a estória". Nosso Menino parece chegar, no trajeto do primeiro ao último conto, ambos "margens" da travessia do livro e da própria existência humana, ao que Rosa professava como chave de sua felicidade, "Vivo no infinito; o momento não conta" (LORENZ, 1991, p. 72). Das margens da Alegria, rio que é, para o autor, "uma palavra mágica para conjugar eternidade" (LORENZ, 1991, p. 71), no qual se aprende a navegar mesmo entre o contentamento e a desilusão, aos cimos da descoberta, dentro do tempo cronológico e cíclico, de uma dimensão de eternidade e mistério. O infante rosiano, irmanado aos pássaros que o levam por este percurso, descobre no céu um gosto de chão e, na finitude terrena, uma porção do infinito. Esta imagem foi cifrada igualmente nas ilustrações que acompanham cada conto no índice final. A sequência de desenhos que ilustram "As margens da alegria" inicia-se com o símbolo do infinito e termina com o símbolo astrológico da Terra; a d'"Os Cimos" abre-se com o mesmo infinito e encerra-se com imagem do Sol.

Ao final, o Menino novamente dentro do avião, prestes a tocar o solo, responde ao Tio que lhe anuncia a chegada com um enigmático " - Ah, não. Ainda não...". Entre "sorrisos e enigmas seus", ele nos suspende entre um tempo que segue, "e vinha a vida" (p. 234), e um tempo que, como o tucano, retorna, encerrando-se o conto - e, portanto, todo o livro - com um retorno ao início, à cena da criança em voo que abre estas "Primeiras Estórias", originárias e originais, antigas e novas, estendendo a nós, leitores, a mesma experiência cíclica e sua dimensão de eternidade. 


\section{Capítulo 6. Origem, Fim: "... até se virar menino"}

\subsection{Fios que se cruzam... com outros infantes}

Ao lado dos pequeninos que nos trouxeram até aqui, no rastro daquilo que Rosa faz emergir enquanto imagem do infante, há outros que certamente mereceriam lugar. Não sendo possível estender a análise para olhá-los na minúcia de suas particularidades e nas múltiplas camadas que os constituem dentro de seus respectivos enredos, gostaríamos, todavia, de invocar alguns deles nos aspectos que partilham com as figurações do existir infantil que percorremos ao longo destas páginas.

A dimensão de uma relação outra com a palavra, nesse lugar "original" e "originário" dos infantes, não constrangido pela racionalização ou usos referenciais, mas onde som e sentido se amalgamam para tecer formas de comunicação nas fronteiras entre a poesia e a magia, seja porque criam uma realidade, seja porque logram diálogo com seres "não falantes", comparece, como vimos, no conto "Tresaventura" e "A menina de lá". São elas as mais novinhas protagonistas rosianas, assim as mais próximas desse "lá", campo do aberto, do mistério, onde as fronteiras entre subjetividade e objetividade se esfumaçam, bem como as leis da não contradição... sua participação no mundo e na linguagem criativa é tão íntima que atingem condição demiúrgica: Nhinhinha, vimos, realiza pela palavra o Ato Criador, o milagre em que "a palavra se fez carne", materializando seus desejos à vontade; tem, além disso, todo o seu ser voltado para o alto, os pássaros, as estrelas, o céu, o "além", desejosa de visitar esse "lá" em que vivem os parentes mortos; esse "lugar fora de todos os lugares", o "lá" rosiano, metafísico, inalcançável, reaparece em outras obras do autor, inclusive no título do conto "Lá, nas campinas"139. Djá/Iaí, de "Tresaventura", igualmente sonhava um "lá", o arrozal, antes metafísico do que físico, "por cima do mundo, no miolo da luz", uma vez que nunca o vira, mas o trazia como um relembramento; também ela tem relação especial com a palavra, revelada na comunicação com a natureza, antes intuitiva do que verbal, pegando no ar um "chamado de socorro" do sapo. Mais conectadas a

139 Ver, sobre esta temática, o artigo de Leyla Perrone-Moisés, "Nenhures 2: Lá, nas campinas", SCRIPTA, Belo Horizonte, vol.2, n.3, $2^{\circ}$ sem. 1998. p.183 e seg. Nele, entre outras valiosas imagens, a autora relembra definição do próprio Rosa, em seu prefácio "Aletria e Hermenêutica", sobre este lugar fora e dentro de todos os lugares: "o de algum Éden pré-prisco, ou da restituição de qualquer de nós à invulnerabilidade e plenitude primordiais." 
instâncias espirituais ou metafísicas do que os adultos, sua dimensão infante transparece na comunicação que se dá por vias outras que não a palavra-utilitária, mas certa palavrapensamento, palavra-música, criativa e admirativa, irmanada, assim, à palavra poética e arcaica, passível de comunicar inclusive com outros reinos que não o humano, com outros mundos que não o imanente. Em "Partida do Audaz navegante", em chave menos metafísica, o manejo fluido, inventivo da palavra-narrativa de Brejeirinha altera a realidade do casal amoroso e da própria protagonista.

No conto "O burrinho pedrês", de Sagarana, há relato breve, mas que ganha destaque na boca de um dos vaqueiros por seu caráter assombroso, cujo protagonista, um menino pretinho, "Assinzinho, regulando por uns sete anos, um toquinho de gente preta" $\left(1978\right.$, p. 54) ${ }^{140}$ com sua palavra-canto parece tocar o ponto de querência e tristeza que o irmana aos bois, em um entendimento tão profundo entre homem e animal que, no meio da noite, a boiada estoura doida, rompe o cerco que a transportava, arrancada de seu lugar de origem, da mesma forma como o menino gostaria de poder fugir da comitiva que o levava para entregá-lo a um tio distante e retornar à casa de sua mãe. Da viagem em que vinha trazido chorando na garupa do narrador, implorando para voltar, nos é relatado que "... o gado também vinha trotando triste, não querendo vir. Nunca vi gado para ter querência daquele jeito." (p. 55). E é numa noite, com o gado "encantoado" numa bocaina, que o menino, ao sol-se-pôr, começa a cantar: "Ah, se vocês ouvissem! Que cantiga mais triste, e que voz mais triste de bonita!...". E a letra da cantiga, "linda, linda como uma alegria chorando, uma alegria judiada, que ficou triste de repente" diz "...Ninguém de mim / ninguém de mim / tem compaixão" (p. 57). Realmente, os homens não têm compaixão, mas os bichos sim; o gado que, desde o início da toada foi ficando "desinquieto, desistindo de querer pastar", e que nas pausas do canto urrava ou gemia "parecendo que estavam procurando, todos de cabeça em pé" (p. 57) irá padecer com o menino; no meio da noite, em comunhão de sentimento e desejo, a boiada toda estoura, desembestada. Um que ouve o relato comenta "Saudade em boi, eu acho que ainda dói mais do que na gente." (p. 58). E não nos deve escapar que, para ambos, é a saudade-querência do lugar de origem que está em jogo. Se a visão noturna do narrador, de "um menino prêto passar cantando, tôda vida, tôda vida,

\footnotetext{
${ }^{140}$ A partir daqui, todas as citações de Sagarana serão acompanhadas apenas do número de página da referida edição.
} 
sentado em cima do cachaço de um marruaz nambijú" foi verdade ou sonho, ele já está velho para querer saber, mas o pretinho, ninguém mais viu nem teve dele notícia...

O canto, a palavra poética, se tece de muitas outras dimensões para além da decifração racional. A criança, por meio dela, dá corpo ao seu sentir e faz ponte com o sentir não apenas dos bois, mas de tudo aquilo que, nos próprios homens, mora em lugares "outros", lugares de "desrazão"141 ... O Seu Saulinho, chefe da comitiva, ao ouvir o canto pega as cartas que recebe da mulher e se põe a olhá-las; ele, analfabeto, também habita o universo das palavras em comunicação afetiva aquém - ou além - do logos. E o narrador é reportado igualmente às suas origens, seu lugar infante: "Aí, então, eu comecei a me lembrar de uma porção de coisas, do lugar onde eu nasci, de tudo..." (p. 57). O texto rosiano novamente desdobra sentidos em suas palavras: os bois inicialmente "encantoados", ajuntados num canto pelos vaqueiros, serão "encantados pela toada" do menino, e põem em ato aquilo que ele, na sua condição submissa e frágil, não poderia fazer por si.

Imagem parecida se encontra em outro conto de Sagarana, "Conversa de bois". O menino carreiro, Tiãozinho, sob a tutela tirânica de Seo Agenor Soronho, patrão que se engraçava com sua mãe e agora transporta no carro, junto com a rapadura, o corpo do recém falecido pai do menino, irmana-se aos bois na condição de "rês", igualmente "aguilhoado", forçado a obedecer ordens e vontades do fazendeiro, "jungido" ao carro não pela canga, mas por sua condição de infante aliada à pobreza. O conto tece paralelamente à narrativa da viagem tanto os pensamentos do menino, feitos de tristeza, rememorações, raiva e ímpetos de vingança, como a "conversa" dos bois do carro que, entre reflexões e lembranças, evocam o triste fim de um boi que raciocinava como os homens: visando economizar caminho do pasto à aguada, deixando de lado suas faculdades instintivas, subiu a um ponto do morro que "tudo era lugar aonde boi não ir", segundo os outros, e despencou-se de lá.

Os animais, em geral, encarnam uma existência de atualidade pura, o puro ser; se Rosa aqui dota os bois de um pensamento, ele o faz revelando, nessa linguagem, um lugar de existência primitivo, regido pelo instinto, as inteligências corporais, sensoriais, e o próprio encadeamento sintático com que lhes plasma a "conversa" tem predominância de períodos simples, orações coordenadas, que mais "apresentam"

\footnotetext{
${ }^{141}$ A segunda parte deste capítulo, “Adultos e velhos que existem infantes”, olha mais detidamente para as dimensões infantes que aparecem em personagens rosianas adultas.
} 
cenas/sensações do que encadeiam reflexões. Nessa maravilhosa tensão que a literatura cria ao fazer a linguagem dizer o que é da ordem do não-reflexivo, não-pensante, pelo menos não no sentido do pensar racional e cartesiano, emerge trecho em que os bois distinguem seu pensamento, seu "saber", daquele dos homens: "O nosso pensamento de bois é grande e quieto... Tem o céu e o canto do carro... O homem caminha por fora. No nosso mato-escuro não há dentro nem fora...", ao que outro boi complementa: "É como o dia e a noite... o dia é barulhento, apressado... a noite é enorme" (p. 318). O crítico e filósofo Benedito Nunes, discorrendo a respeito dos bichos na obra de Clarice Lispector, observa que estes assumem uma posição análoga àquela que Raine Maria Rilke lhes atribui na Oitava Elegia de Duíno, com que as falas de nossos bois guardam forte ressonância:

\begin{abstract}
"Eles veem o aberto - o grande espaço que inclui todos os espaços - e participam da realidade. São mais vivos e mais seguros do que nós e, mais do que os humanos, possuem a existência e o Ser. Enquanto os homens, desgarrados do Ser, têm um destino a fazer, os animais permanecem no seio da realidade que os engendrou. São fios inseparáveis da trama que o Absoluto tece." (NUNES, 2009, p. 123)
\end{abstract}

Nesse lugar da origem, noturno, aberto, o infante com eles se encontra. São os próprios bois que, logo após as falas acima, exprimem essa proximidade:

"O bezerro-de-homem sabe mais, às vezes... Ele vive muito perto de nós, e ainda é bezerro... Tem horas em que ele fica ainda mais perto de nós... Quando está meio dormindo, pensa como nós bois... Ele está lá adiante, e de repente vem até aqui... Se encosta em nós, no escuro... No mato-escuro-de-todos-os-bois... Tenho medo de que ele entenda a nossa conversa..." (p. 318-19).

Estava certo o Boi em seus receios. No entreposto de sono e vigília, que comunga das dimensões noturnas do ser, lugar da palavra-corpo, palavra-som, palavrapensamento desgarrada das contingências racionais se dará, mais do que comunicação, verdadeira "participação" do pensamento-sentimento de Tiãozinho e dos bois, a ponto de não lograrmos distinguir mais, nas linhas do conto, o que é discurso de um e de outros... e vamos recebendo por meio do Boi Capitão uma fala que rompe as barreiras 
que separam o eu e o outro, amalgamam o pensar, o sentir e a própria existência individual dos seres, bois e menino, em um só, o uso do hífen marcando textualmente essa fusão:

\begin{abstract}
"Mhú! Hmoung!... Boi... Bezerro-de-homem... Mas, eu sou o Boi Capitão!... Moung!... Não há nenhum Boi Capitão... Mas, todos os bois... Não há bezerro-de-homem!... Todos... Tudo... Tudo é enorme... Eu sou enorme!... Sou grande e forte... Mais do que seu Agenor Soronho!... Posso vingar meu pai... Meu pai era bom. Êle está morto dentro do carro... Seu Agenor Soronho é o diabo grande... Bate em todos os meninos do mundo... Mas eu sou enorme... Hmou! Hung!... Mas, não há Tiãozinho! Sou aquêle-quetem-um-anel-branco-ao-redor-das-ventas!... Não, não, sou o bezerro-de-homem! Sou maior do que todos os bois e homens juntos." (p. 319)
\end{abstract}

Esse pensamento-palavra que, em um crescente de esfumaçamento da linguagem boi-menino, traz o signo do desejo de poder e vingança de Tiãozinho, contamina todos os bois do carro, os outros "oprimidos" da história e, nessa identificação, como no caso do pretinho, são eles os agentes da vingança: aproveitamse do descuido de Agenor Sorônho, que dormia em cima do carro, e arrancam todos juntos; o patrão cai, e o carro lhe passa por cima.

As dimensões "noturnas", "misteriosas" desse lugar de existência original podem levar, como vimos, a uma proximidade da existência infantil com o aberto em sua forma última: o "lá", alhures, origem e fim desconhecido, terceira margem que pode também ser identificada com a morte. Nhinhinha, a "Menina de lá", talvez seja figuração mais extrema dessa relação. Paralelamente a ela podemos evocar o "Moço muito branco", de conto homônimo, que chega misteriosamente à vila, ninguém sabe de onde. Como Nhinhinha, seus olhos se voltam para o alto, para a luz: "De estranha memória, só, pois, a de olhar ele sempre para cima, o mesmo para o dia que para a noite - espiador de estrelas" (2001, p. 153) ${ }^{142}$ e, exatamente como ela, pára alheado, num sorriso que o exporta para "lá": "Seu sorriso às vezes parava, referido a outro lugar,

\footnotetext{
${ }^{142}$ Lembremos que Nhinhinha as contemplava igualmente, chamando-as "estrelinhas pia-pia". A partir daqui, todas as citações de Primeiras Estórias serão acompanhadas apenas do número de página da referida edição.
} 
outro tempo" (p. 151). Com seu estranho ser, que opera por inteligências outras, no silêncio e na presença de extrema atualidade modifica comportamentos e sentimentos dos habitantes. Um belo dia, "o moço se fora, tidas asas" (p.155), a destino igualmente desconhecido.

Dito, irmãozinho de Miguilim, apesar de nada "etéreo" como estes dois personagens, de vontade ativa, inteligência aguçada para a prática do acontecer das coisas, inteirado inclusive das relações, trabalhos e acontecimentos do universo dos adultos, tem vislumbres de sabedoria que guardam ecos do "saber" = "lembrar" da teoria da reminiscência platônica ${ }^{143}$ e viverá essa aproximação do mistério, do insondável... Longe de desejá-la, como Nhinhinha, sua confissão a Miguilim de que tem medo da morte e não quer "ir para o céu menino pequeno" parecerá cruel profecia... $\mathrm{Na}$ progressão da doença que o mantém acamado, tolhendo-lhe aos poucos os movimentos, sua sabedoria do mundo objetivo, que inclui arguto conhecimento da psique humana ou preceitos morais algo filosóficos ${ }^{144}$, toma outro rumo, e ele partilha especialmente com Miguilim saberes de quem está vislumbrando a vida a partir de uma proximidade com o fim: "Miguilim, eu sempre tinha vontade de ser um fazendeiro muito bom, fazenda grande, tudo roça, tudo pastos, cheio de gado... [...] Mas depois tudo quanto há cansa, no fím tudo cansa..." (2001, p. 117) ${ }^{145}$; e, já nos instantes derradeiros, Dito revela o saber maior a que chegou: "Miguilim, Miguilim, vou ensinar o que agorinha eu sei, demais: é que a gente pode ficar sempre alegre, alegre, mesmo com toda coisa ruim que acontece acontecendo. A gente deve de poder ficar então mais alegre, mais alegre, por dentro!..." (p. 119).

A lição do Dito prevê um lugar de desprendimento absoluto da identificação do sujeito com o mundo objetivo, uma capacidade de ultrapassar o princípio da dualidade, de preferências e aversões, alçando-se a consciência a estado ideal de reintegração na totalidade perdida, não mais afetada pelas circunstâncias externas sempre cambiantes...

\footnotetext{
143 "De mesmo, de tudo, essa ideia consegue chegar em sua cabeça, Dito?" Ele respondia que não. Que ele já sabia, mas não sabia antes que sabia" (p. 132)

${ }^{144}$ Há inesquecível episódio em que Dito manda o vaqueiro Jé cortar a alta árvore de flor que, segundo crença popular, caso ultrapassasse a altura da casa, traria morte a algum de seus moradores. Miguilim, temendo morrer, a queria cortada, o Pai dá ordens que não cortem; mas Dito se safa do castigo alegando que sonhou que era o pai que morria, então mandou cortá-la pois gostava demais do pai e não queria de jeito nenhum que algo lhe acontecesse. Há ainda suas respostas a algumas confusas questões a respeito de bondade e maldade, postas por Migulim: "O ruim tem raiva do bom e do ruim. O bom tem pena do bom e do ruim... assim está certo [...] O mole judiado vai ficando forte, mas muito mais forte! Trestempo, o bruto vai ficando mole, mole..." (p. 110)

145 As seguintes citações da novela "Campo Geral" serāo acompanhadas apenas do número da página da referida edição.
} 
desprendimento talvez mais simples para aqueles cuja existência se faz permear pelo "aberto", o "inominável", o "lá", como Nhinhinha, que diante das adversidades circunstanciais murmurava só "Deixa... deixa...". Nas palavras da cozinheira Rosa, única que consola Miguilim em seu luto, o Dito "[...] era uma alminha que via o Céu por detrás do morro, e que por isso estava marcado para não ficar muito tempo mais aqui" (p. 124); imagem comumente evocada para as crianças que morrem na flor da idade... crianças-anjinho, figurando essa existência que comunga da unidade originária de onde vieram e, ao mesmo tempo, da insondável totalidade para onde parecem retornar. Benedito Nunes explica a ambiguidade "alfa e ômega" da existência infantil a partir de dupla simbologia - por um lado, alma que nasceu da Unidade Primordial, partícipe, portanto, da indistinção caótica anterior ao conflito dos princípios opostos do mundo sensível. Por outro, simboliza novo nascimento, reintegração da alma dividida que recupera sua unidade congênita e a harmonia que supera os contrários que a dividem no estágio terreno de sua peregrinação (NUNES, 2013, p. 67). Daí muitas vezes a conjunção de "juventude e velhice" quando se atenta à sabedoria particular dos pequenos, que a mesma Rosa ressalta para Miguilim: "E disse que o Dito parecia uma pessôinha velha, muito velha em nova" (p. 124).

Nessa esteira de uma existência infante marcada pela ambiguidade que conjuga Unidade Primordial e Reintegração na Totalidade, o próprio Benedito Nunes analisou o Menino Diadorim. Marcando o destino de Riobaldo, simboliza tanto o momento ancestral, do velho ser humano dividido que permanece presa das forças elementares, materiais e sensíveis, quanto o momento por vir, da reintegração de opostos (masculino e feminino, deus e diabo), no caminho de aprendizagem que é a própria vida, o vir a ser do sujeito (NUNES, 2013, p. 71). Mais do que qualquer outro infante, ele é portador do signo da androgenia que, nos lembra Mircea Eliade, "é uma fórmula arcaica e universal para exprimir a totalidade, a coincidência dos contrários" (1957, p. 234), e por isso era traço encontrado tanto em deuses quanto em deusas. Como as teofanias primitivas, Diadorim é a um só tempo divino e diabólico, seduz e aterroriza, fascina e inquieta o menino Riobaldo, que dele recebe tanto a delicadeza sensível do olhar para a natureza quanto a força bruta da violência que fere na faca sem hesitar. Se vimos que a existência infante é, em Rosa, figurada muitas vezes por meio da coincidentia oppositorum, de carência e potência, do infinitamente pequeno e do infinitamente grande, em Diadorim serão múltiplos os signos dessa ambiguidade, que Adélia Bezerra de Meneses (2010) aprofunda a partir dos componentes do próprio nome da personagem, e seu núcleo 
último guarda os grandes temas humanos e metafísicos: Amor e Ódio, Medo e Coragem, Bem e Mal, Deus e Diabo.

\subsection{Adultos e velhos que existem infantes}

Natal é noite nova de antiguidade ("Presepe") Você chegou a existir? ("O Espelho")

O estudo que fizemos até aqui perseguiu essa forma de existência que chamamos "infante"; não o intitulamos "a criança na obra de Guimarães Rosa" porque, apesar de própria dos pequeninos, ela se faz, como aponta Nunes, não apenas momento inicial, mas lugar de existência por alcançar, forma de ser regida por lógica outra a moldar nossa relação com a linguagem, a natureza, os seres e as coisas - e o avesso delas: o insondável, o mistério. Se em alguns contos até aqui a polaridade entre a criança e o adulto se revelou mais acirrada, veremos alguns adultos e velhos que, com seu existir infante, desfazem esta possível percepção binária, repondo para nós o mundo misturado rosiano em que as polarizações participam umas das outras, em uma dança contínua. Dentre os velhos, há ao menos dois personagens que se destacam pelo que iluminam das aproximações entre aqueles cuja existência se faz próxima ao lugar originário que marca o início e o fim de nosso caminho.

A velhice e a infância se comunicam em mais de uma instância - uma ainda aquém, outra quiçá já além da intrincada malha de normas, moralidades, ditames sociais e culturais, ambas próximas da região desconhecida que antecede e prossegue o que nos é dado conhecer enquanto existência, e emergem, portanto, como "desviantes" do ethos hegemônico que a sociedade toma por norma. A certos velhos, assim como aos infantes, importa pouco o caráter utilitário do que quer que seja, ações ou palavras, e também eles fruem maior liberdade, quer em suas ações, quer em seus devaneios. $\mathrm{O}$ existir que chamamos infante, em sua potência criativa, comunhão com o mistério, capacidade intuitiva e participativa com os seres e as coisas emerge não como mero "regresso", mas como devir em personagens que já atravessaram a existência e, ao fim desse caminhar, lograram alcançá-lo.

A "Estória de Lélio e Lina" é todo um périplo da juventude que desponta no cenário da fazenda do Pinhém, à qual o vaqueirinho Lélio chega; jovens vaqueiros e moças do lugar estão às voltas com seus desejos, namoros, ambições, anseios de 
pertencimento ou destaque social, dramas, vergonhas, e a pungente descoberta e exploração da sexualidade. E no meio disso tudo há... uma velha, velhinha, Dona Rosalina, a quem, no entanto, Lélio vislumbrou primeiro como imagem de moça: "[...] vestida de claro, ali perto, de costas para ele, uma moça se curvava, por pegar alguma coisa no chão. Uma mocinha" (ROSA, 1978, p. 179) ${ }^{146}$, que ajeita o pano verde na cabeça. É cena que o arrebata para fora do usual do tempo, a visagem de "riso, brilho, uns olhos" se dá para ele em um "vazio de momento", como quando, em ocasião em que se viu à beira de desastre e morte, sem saída, fechara os olhos e "foi como se tivesse subido dali, em neblinas, para lugar algum, fora de todo perigo, por sempre, e de toda marimba de guerra." (p. 179). Esse "lá", dentro e fora do mundo, assemelha-se a portal de tempo mítico, tempo-sobre-tempo, e o que Lélio vislumbra é menos imagem do passado, da "Rosalina moça", e mais a substância de juventude que a habita, o paradoxo de sua suma existência de velhinha-moça. Rosalina congrega em si meninice e velhice, tudo nela faz coincidir esses opostos: "[...] mas voz diferente de mil, salteando com uma força de sossego" (p. 179); "salvante que aquela firmeza em pisar e caminhar não dizia de mulher idosa" (p. 180); "Velhinha, os cabelos alvos. Mas, mesmo reparando, era uma velhice contravinda em gentil e singular - com um calor de dentro, a voz que pegava, o aceso rideiro dos olhos, o apanho do corpo, a vontade medida de movimentos [...]" (p. 181) - até em suas agregadas temos, lado a lado, a menina Crispininha e a velha Góga.

É velhinha em quem a chama do erotismo, da sensualidade, jamais se apagou, antes transformou-se em graça e experiência, uma verdade forte que emana e atrai as pessoas a si; mas sua forma de existir guarda pontos de contato também com o existir infante: livre de máscaras sociais, diz seus afetos e opiniões sem hesitar; pega no ar "a coisa das coisas e a pessoa das pessoas", como Brejeirinha ${ }^{147}$, dando a Lélio síntese do núcleo constitutivo de cada um dos vaqueiros do Pinhém e muitas vezes adivinhando de onde ele vem e o que lhe vai na cabeça e no coração, antes mesmo de seu "Mocinho" lhe proferir palavra. Como muitos dos pequeninos que vimos, sua forma de contemplar e dizer o mundo resgata as coisas de seu lugar reificado, utilitário, para uma relação íntima, poética, gratuita, que devolve alma ao mundo, reencanta-o, "salvando" as

\footnotetext{
146 As próximas citações da novela vêm acompanhadas apenas do número da página da referida edição. ${ }^{147}$ A frase é do conto "Partida do Audaz Navegante" (ROSA, 2001, p.168), que exploramos no capítulo 4 deste trabalho.
} 
palavras do desgaste de uma impessoalidade gramatical, infante e rosianamente trazendo-as para perto de si, do "lado de cá":

A mais, tirava, das coisas, do mato, da noite, do céu, um risco de conversa à toa - mas para estremecer essa alegriazinha sem paga que escorre num tocado de viola ou numa volta de cantiga: -"Sobre por cima da lagoa, de tarde, estão jogando umas violetas" [...] "Tem um anjo desterrado na lua... Do lado de lá da lua, há luz e festa..." Resumia, aquela moita de bambu, perto da casa, e que alongava em tom do vento. Ela falava: - "É bom, ficar junto de lá, para poder ouvir o bambual gemer." O bambual se encantava, parecia alheio uma pessoa. Eram coisas salvadas, para cá, sem demora - as palavras." (p.

Ouvindo essa Palavra, modo singular de ver e dizer o mundo, Lélio percebe que, mais do que o dito em si, "[...] o siso da gente achava que ela estivesse ensinando outro poder inteiro de se viver" (p. 192). Um poder de se viver que guarda traços "originários" e "originais", nova-velha forma em cujo núcleo está uma abertura, uma alegria, uma comunhão com a vida. Ela dá a Lélio o saber de que no fim está o começo, a vida é um devir que se abre, no início, no fim, e sempre, para aquilo que está no cerne da existência, força suprema que se encontra nos primórdios dos tempos, deus mais antigo da cosmogonia grega e eternamente menino, Eros, o amor: "Um dia você ainda vai ver, meu Mocinho: coração não envelhece, só vai ficando estorvado... Como o ipê: volta a flor antes da folha..." (p. 182). Com essa velhinha-moça, Lélio aprende a existência e o amor, e com ela segue sua viagem...

O conto "Presepe", sintético como a cena representativa do mistério a que seu título alude e, de resto, como a linguagem desse livro de si já intitulado com o signo da brevidade, Tutaméia, nos traz em personagem bem diversa de Rosalina talvez a figuração simbólica mais extrema de encontro entre fim e princípio, velho e criança. É noite de natal, e Tio Bola, já nos seus oitenta anos, junto dos outros dois desmerecidos, o terreireiro Anjão, idiota, e a cozinheira Nhota, cardíaca, é deixado na casa de fazenda pela família que segue para a cidade assistir à Missa do Galo. Ao contrário do viço de Dona Lina, aureada de respeito e afeto diante da comunidade do Pinhém, a velhice 
invalida Tio Bola e, como aos outros dois, o exclui da vida comunitária e suas celebrações. Mas "Natal era noite nova de antiguidade" (1969, p. 119) ${ }^{148}$ que lhe permite encontrar, mais do que comunhão, a ressignificação de seu tempo e existência naquele que é, na religião cristã, arquétipo do Eterno Começo.

Início-fim, infância-velhice são os opostos que se tocam em nosso caminho circular da vida ${ }^{149}$. Há um inegável aspecto regressivo na velhice que a aproxima de experiências infantis: a memória se vê frequentemente retornando àqueles tempos, enquanto o corpo torna a apequenar-se; dificuldades no falar, caminhar, controlar funções excretoras ou motoras se reapresentam e novamente há que depender dos adultos circundantes, aceitar suas regras e imposições; paralelamente, a lógica e os valores que os velhos assumiram quando adultos tornará a se parecer demais com a que tiveram enquanto infantes: não mais a faina atabalhoada do trabalho, a produtividade pragmática, a preocupação social ou política, mas tempo outro, contemplativo, admirativo, deleite com o mundo em sua orgânica beleza, sua poesia latente, o raciocínio lógico cedendo a caprichos, intuições, fantasias, novas soltas asas para delírios e desejos...

Assim, nosso Tio Bola, ao recolher-se para dormir, ouve da Nhota refrão repetido aos pequenos: "Mecê não mije na cama!". Ele, que tem de descer com cuidado as escadas e, antes tão gordo, de valer-lhe o apelido, agora pequenino, magro, fraco, caberá facilmente no cocho em que se deita à meia noite, permitindo-se realizar o que o narrador pontua, ao longo do texto, por vezes ecoando pensamentos do próprio protagonista, como fantasia delirante: "A ideia lhe chegou então, fantasia, passo de extravagância" (p. 119); "Caduco de maluco não estava" (p. 120); "Que o achassem sem tino perfeito, com algum desarranjo do juízo!" (p. 121).

A imagem de carência, contudo, emerge como potência nessa extravagância sem juízo de celebração natalícia quando Tio Bola tem a ideia de tornar-se, ele mesmo, parte do presépio - de resto invenção do santo que mais se assemelhava às crianças em sua pureza inocente, êxtase com a natureza, sublime amor pelos bichos e assombrosa comunicação com eles. Francisco, o "palhaço de Deus", foi também julgado "com

\footnotetext{
${ }^{148}$ A partir daqui, as citações do conto virão acompanhadas apenas do número de página da referida edição.

${ }^{149}$ Não por acaso em Corpo de Baile Rosa abre o périplo das sete novelas com as duas pontas da vida, "Campo Geral", cujo protagonista é a criança e seu despertar, abrir de olhos na aurora da existência, e "Estória de Amor", com o velho Manuelzão já no ocaso da vida, tendo enterrado a mãe e questionando suas forças para acompanhar nova boiada em viagem marcada daí a dias.
} 
algum desarranjo de juízo" em seus atos de reinvenção da fé e da própria existência humana segundo o cristianismo. Toda carência, desvalimento e exclusão que irmanam infância e velhice no início do conto, portanto, revertem-se nesse ato de Tio Bola que, um tanto fransiscanamente, "quis ver visões" e, em sua desrazão plena de verdade ${ }^{150}$, salta do tempo cronológico devorador, que lhe acena com inexorável fim, para o tempo mítico instaurado no curral em que boi e burro estão à manjedoura "como quando os bichos falavam e os homens se calavam" (p. 119).

Por volta das dez horas, o velho desce as escadas, silencioso e só, os demais adormecidos ou distantes, e dirige-se ao curral. O conto adensa as imagens do corpo da noite, dimensão do oculto, esquecimento e mistério, irmã da morte, escuridão que engole o contorno nítido das formas, sons e pensamentos, dentro da qual Tio Bola espera: "Espiou em redor - caruca - que nem o esquecido, em vivido (...) Estava ali a não imaginar o mundo"; "Só o viço da noite - o som confuso?" (p. 120). Fora do tempo cronológico, quando "O mundo perdeu seu tique taque" e "a hora dobrou de escura", a noite caminha para o centro de seu mistério, o limiar em que fim e início coincidem, meia-noite, e Tio Bola deita-se no cocho, em gesto que, ele mesmo sabe, não o iguala ao Menino-Deus em pureza recém-nascida, posto os separem as cargas de toda uma vida transcorrida, mas no mistério da solidão original ${ }^{151}$ de que participam igualmente nascimento e morte. Imagem extrema de conjugação de opostos, o cocho é a um só tempo campa e berço, e nele o velho se entrega... ao sono dos recém nascidos ou ao sono último da morte? "Soporava. Dormiu reto. Dormindo de pés postos". Mergulho no não-ser que é, a um só tempo, ser pleno, fim e início, Velho e Eterno Menino; essa hora "fazia futuro" engendrando na morte a pulsão de vida: "Da noite era um brotar, de plantação, do fundo. A noite era o dia ainda não gastado." (p. 121)

Deitado no cocho do presépio, Tio Bola atravessa sua Meia Noite para realizar que "O contrário daqui não é ali..." (p. 121), em gesto que conjugou ao extremo da velhice a dimensão amanhecente da infância: "Acordou, no tremeclarear" (p. 121). É gesto que, de tal força, contaminou os demais excluídos, desvelando no imbecil Anjão sua qualidade angelical, a se rir para o sol, e em Nhota, cardíaca de curto fôlego, a

\footnotetext{
150 "Tremia de verdade" (p. 120), diz o narrador acerca da visão do curral com o boi e o burrinho.

151 "Não como o Menino, na pura nueza... O voo de serafins, a sumidez daquilo. Mas, pecador, numa solidão sem sala."(p. 120-121)
} 
capacidade do canto, que ela entoa em celebração à vida ${ }^{152}$. Vivida a comunhão com a Morte e o Eterno Começo, Tio Bola dá ordens e sobe as escadas: "Amém, Jesus!"

Para além das imagens de forte carga arquetípica que os velhos-infantes encarnam, há adultos cuja existência se faz infante. O Grivo aparece pela primeira vez, ainda menino, na novela "Campo Geral". Muito mais acossado pela pobreza do que a família de Miguilim, tem, todavia, o dom de fabular, contar histórias compridas, diferentes das outras, e Miguilim diz "[...] a gente ficava logo gostando daquele menino das palavras sozinhas" (ROSA, 2001, p. 100). Pois esse menino será, adulto, o vaqueiro escolhido para ir atrás do "quem das coisas" na novela "Cara-de-Bronze". Segisberto Jéia, cujo apelido dá título à obra, é o afamado e acamado patrão, já velho e doente, senhor de terras de muito gado que, segundo seus vaqueiros, estaria "caducável", porque agora, em vez de coisas proveitosas, relatos sensatos da lida dos campos, das caças e onças, bom ou mau tempo, indagava "engraçadas bobéias" e, para determinar quem será o viajante capaz de lhe trazer o nome das coisas, organiza torneios feitos de "mariposices", que consistiam em batizar lugares sem nome, ou mudar o nome dos já existentes, ser capaz de identificar qualidades raras, descrever o que escapa ao dizível, a face mais sutil do mundo, de bichos, plantas, paisagens, por meio de jogos inusitados com as palavras, "não entender, não entender, até se virar menino" (ROSA, 1978, p. $101)^{153}$... Grivo será o vencedor deste torneio.

Não é difícil perceber aqui, nesse retorno a uma meninice, aquém do entendimento viciado das coisas, quase todos os aspectos que viemos ressaltando como característicos do trato infante com a linguagem: o olhar inaugural, experiência adâmica de nomear ${ }^{154}$, de manejar as palavras para além das normas, da função referencial, mas sim na função poética e mítica, que nomeia não para representar, mas para fazer existir o mundo. Novamente Benedito Nunes, em ensaio que persegue o tema da viagem nesta novela, declara que a missão do Grivo "[...] foi retraçar o surto originário da linguagem, recuperar a potencialidade criadora do Verbo" (2013, p. 91). E Grivo o vai retraçar para revitalizar aquele que se encontra acamado, debilitado, o patrão que tem a marca de

\footnotetext{
152 "Nhota entoava o Bendito, não tinha morrido" (p. 121)

${ }^{153}$ As próximas citações da novela vêm acompanhadas apenas do número da página da referida edição.

${ }^{154} \mathrm{O}$ rol de nomes de árvores e plantas, em detalhes, das mais frondosas ao capim rasteiro, aves de mile-uma espécies, animais, mamíferos, anfíbios, traços da paisagem inclusive semoventes, como desenhos de sombras e nuvens, nos fazem lembrar a relação Bíblica, à maneira do Gênese ou do Deuteronômio, como já apontou Benedito Nunes (2013, p. 91), e a ela somam-se descrições de homens e mulheres de idades várias, suas profissões, costumes, moradas, alimentos ou ausência deles... a fome e a fartura, alegrias e tristezas...
} 
Saturno no nome, planeta associado à melancolia e ao estado meditativo ${ }^{155}$, e cuja identidade conjuga ainda fim e início, velhice e juventude: Segisberto Saturnino Jéia Velho, Filho. Se em sua mocidade buscava a riqueza material, dedicado ao trabalho e aos cálculos, estes parecem tê-lo esgotado. Agora, velho, sua busca é o retorno a uma espécie de olhar menino para as coisas, ouro de outra natureza ${ }^{156}$, o da imaginação, que ele mesmo não logrará buscar, pois não se trata de uma busca física: o universo da riqueza material se debilitou, e é necessário uma espécie de Hermes mensageiro para trazer os assuntos que ele encomendava: “[...] imaginamento. Toda qualidade de imaginamento, de alto a alto...” (p. 86) - não a face terrena, mas a própria poesia do mundo. Quando os demais vaqueiros pressurosos querem saber, afinal, o que é que Grivo foi buscar para o patrão, não o alcançam compreender, nem o Grivo consegue a eles dizê-lo; porque eles indagam da parte do mundo objetivo, concreto, do "quê" das coisas, com olhos postos no que foi trazido e no que viria como recompensa pelo serviço cumprido. Adulto embora, e vaqueiro como eles, Grivo não indaga em momento algum pelo prêmio; ele guarda essa rara faculdade de "[...] ver o que no comum não se vê: essas coisas de que ninguém não faz conta", e de "tirar a cabeça, para fora do doido rojão das coisas proveitosas" (p. 105), faculdades próprias dos infantes que não se imiscuíram na faina diária, rotineira, utilitária, mas, capturados e atravessados pelos "desacontecimentos importantes", são capazes de palavras igualmente incomuns para dizê-los. É o ponto em que infantes e poetas se tocam; eles, como o Grivo e o Cara-de-Bronze, querem o "quem" das coisas, vão buscá-lo por meio de palavras novas-antigas, originárias e originais, nascidas de uma urgência de tocá-lo; da narração do vaqueiro viajante ao velho fazendeiro brota comoção sentida que só eles partilham:

GRIVO: (de repente começando a falar depressa, comovido): Ele, o Velho, me perguntou: - "Você viu e aprendeu como é tudo, por lá?" - perguntou, com muita cordura. Eu disse: - "Nhor vi". Aí,

\footnotetext{
${ }^{155}$ Ver a esse respeito "A raiz da alma" (1992), de Heloísa Vilhena de Araújo, cujo sexto capítulo, "Saturno" dedica-se à análise de "Cara-de-bronze" em suas correspondências com este planeta.

${ }^{156}$ No mesmo capítulo de "A raiz da alma" (Op. Cit., p. 127), Heloísa Vilhena de Araújo retoma o mito das raças dos homens mortais, segundo Hesíodo, para lembrar que a primeira delas, a Idade do Ouro em que impera a perfeição da vida contemplativa, está colocada sob o signo de Saturno - ele é o caminho para aprender esta contemplação perdida nas idades do Bronze e Ferro. Podemos pensar que nosso "Carade-Bronze", ao final de sua vida, Velho, Saturnino, quer recuperar algo dessa "Primeira Idade" dos homens, as faculdades contemplativa e imaginativa, ambas qualidades infantes que reconhecerá no Grivo.
} 
ele quis: - "Como é a rede de moça - que moça noiva recebe, quando se casa?" E eu disse: - "É uma rede grande, branca, com varandas de labirinto... (Pausa) José Proeza (surgindo do escuro): Ara, então! Buscar palavras-cantigas? Adino: Aí, Zé, opa! ${ }^{157}$ GRIVO: Eu fui... Mainarte: Jogou a rede que não tem fios. GRIVO: Não sei. Eu quero a viagem dessa viagem... Cicica: Dislas! Remondiolas... GRIVO: ... Ele, o Velho, disse, acendido: - "Eu queria alguém que me abençoasse..." - ele disse. Aí, meu coração tomou tamanho. Tadeu: Então, que foi que ele fez, então? GRIVO: Chorou pranto. Adino (com muxoxo): Vigia só... Por pranto de choro, então? Ganho recebido? (p. 126-127).

Contrastando com o muxoxo daqueles que só sabem existir de olhos postos no "ganho recebido", ainda uma vez o discurso aponta, na forma singular de existir do Grivo, para uma "anterioridade de ser", algo desse lugar infante - que é um aquém, mas, vimos, também um além, o que já tivemos e que nos está por conquistar - carência e potência - quando ele, pressionado ainda mais pelos que querem saber se trouxe uma noiva "concreta", mulher desposada, diz: "Ninguém enxerga um palmo atrás de seu nariz", ao que Moimeichego, personagem-símbolo do sujeito, cujo nome condensa o pronome "eu" em 4 línguas ${ }^{158}$, responde "Isso! É preciso é vir aquém..." (p. 125). Lição do Eu: para ser, vir a ser, tocar no núcleo da existência, é preciso "vir aquém"... até se virar menino.

Difícil não lembrar, a essa altura, o conto "O Espelho", que divide o livro Primeiras Estórias em dois blocos, dez contos que o precedem e outros dez que o sucedem, de forma a convidar-nos, como possível chave de leitura, ao espelhamento

\footnotetext{
${ }^{157}$ Rosa mesmo revela a seu tradutor italiano: "Aí, Zé, ôpa!", intraduzível, evidentemente: lido de trás para diante = apô éZ ía, : a Poesia..." (ROSA, 2003, p. 93)

${ }^{158}$ Ainda a seu tradutor italiano, Guimaraães aponta nesta personagem a sua própria pessoa de autor: "Bem, meu caro Bizzarri, por hoje, já exagerei. Encerro. Apenas dizendo ainda a você que o nome MOIMEICHEGO é outra brincadeira: é : moi, me, ich, ego (representa "eu", o autor...) Bobaginhas. (ROSA, 2003, p. 95)
} 
entre esses pares. É, de todo o livro, o único conto que se faz mais ensaístico do que narrativo, apesar de instaurar o discurso oral para um invisível interlocutor - à moda do Grande Sertão: Veredas -, desde a primeira frase: "Se quer seguir-me, narro-lhe" (ROSA, 2001, p. 119) ${ }^{159}$. É relato de experiência vivida, porém arquitetado nas dobras da argumentação, com antecipações de contestação do ouvinte e contra-argumentos do narrador em que se entremeiam teorias as mais várias, desde as leis da física à metempsicose, conhecimentos antropológicos e reflexões de fundo místico ou psicológico acerca do que seja, na verdade, um espelho. Tudo se dá pois nosso narrador, a partir da experiência de ver-se duplicado em espelhos insolitamente posicionados e não ter reconhecido neles seu próprio reflexo (antes, repugnou-lhe a figura que julgava ser um outro no recinto), lança-se a experimentos para chegar ao "eu por detrás de mim" (p. 122), tocar a subjetividade essencial, última, seu ser despido de todos os traços biológicos ou hereditários, mais os sociais, psicológicos, emotivos, todas as camadas, enfim, que se sobrepõem a formar a imagem do sujeito que não é ele mesmo; vislumbrar finalmente essa existência em si, pura, absoluta, irredutível... a que se pode chamar de "alma". A certo ponto da desconstrução radical que passa a operar, com métodos para "não ver" em sua imagem refletida os traços que identifica como "exteriores" a si, nosso sujeito chega... ao vazio. Um dia, olha ao espelho e nada vê. A conclusão, terrível, que aventa:

"[...] não haveria em mim uma existência central, pessoal, autônoma? Seria eu um... des-almado? Então, o que se me fingia de um suposto eu, não era mais que, sobre a persistência do animal, um pouco de herança, de soltos instintos, energia passional estranha, um entrecruzar-se de influências, e tudo o mais que na impermanência se indefine? [...] E, seria assim, com todos?" (p. 126)

Mesmo para a fácil contestação de que a ausência de reflexo nada prova, posto para isso seria forçoso pretender que alma ou psiquismo se retratassem em espelho, o narrador confessa que "pôs os bois atrás do carro" (p. 127) e oferece o final de seu relato como prova última da tese que veio perseguindo; pois se deu que, anos mais tarde, ao fim de ocasião de grandes sofrimentos, ele defrontou-se novamente com algo ao

\footnotetext{
${ }^{159}$ As próximas citações do conto vêm acompanhadas apenas do número da página da referida edição.
} 
espelho... não imagem, mas "o tênue começo de um quanto como uma luz, que se nublava, aos poucos tentando-se em débil cintilação, radiância [...] Que luzinha, aquela que de mim se emitia, para deter-se acolá, refletida, surpresa?" (p. 127); tempo ainda mais longo decorre antes da revelação última que encerra o périplo do sujeito em busca de si:

\begin{abstract}
"Por aí, perdoe-me o detalhe, eu já amava - já aprendendo, isto seja, a conformidade e a alegria. E... sim, vi, a mim mesmo, de novo, meu rosto, um rosto; não este, que o senhor razoavelmente me atribui. Mas o ainda-nem-rosto - quase delineado apenas - mal emergindo, qual flor pelágica, de nascimento abissal... E era não mais que: rostinho de menino, de menos-que-menino, só. Só. Será que o senhor nunca compreenderá?" (p. 127)
\end{abstract}

A imagem regressiva, de menos-que-menino, que se confunde com as origens abissais a que chegou nosso narrador em sua desconstrução de si é, a um só tempo, imagem progressiva, um devir-menino que ele atinge ao atravessar o vazio, mas também a forja do sofrimento e do amor; daqui o salto à última reflexão existencial: se este mundo é o "plano - intersecção de planos - onde se completam de se fazer as almas" (p. 128), viver é a alta tarefa de "vir a ser", realizada no paradoxo, como dissera Moimeichego, de "vir aquém", posto exija "[...] o consciente alijamento, o despojamento, de tudo o que obstrui o crescer da alma, o que a atulha e soterra" (p. 128). Conseguir o devir-menino, a existência infante que toca esse lugar regressivo e progressivo, é tarefa de que depende, não a vida, fato biológico tão inescapável como a morte, mas o "fazer alma" que se nos impõe, podendo a pergunta do juízo final confrontar-nos exigência infinitamente mais aterradora do que o cumprimento de regras ou moralidades: "Você chegou a existir?".

Não por acaso este conto se destaca tanto dos demais, seja pelo estilo, seja pela própria posição articuladora dentro do livro. Nele, Rosa parece dar também aos leitores o espelho não apenas dos outros vinte contos, mas de sua própria concepção da existência ${ }^{160}$, o núcleo que move enredos vários nos quais, seja pelo sofrimento, pelo amor, ou por ambos, suas personagens caminham à roda da vida, nesta alta tarefa de

\footnotetext{
${ }^{160}$ Lembremos que ele se identifica ao personagem Moimeichego, cuja frase-síntese aqui já citamos: "É preciso é vir aquém".
} 
"completar de fazer alma" que aponta para uma existência outra cuja imagem derradeira é um "rostinho de menino, de menos-que-menino", aquém e além de tudo o que a atulha e soterra.

\subsection{Ser-tão infante}

Rosa já tomara a lição a Euclides da Cunha: falar do homem é falar da terra, e falar da terra é falar do homem. Suspeito que não haja qualquer tema que se escolha explorar na obra rosiana o qual não encontre profunda ressonância nas dimensões físicas e metafísicas do sertão. “[...] narrar estórias corre por nossas veias e penetra em nosso corpo, em nossa alma, porque o sertão é a alma de seus homens." (LORENZ, 1991, p. 69), ele confessa a seu entrevistador alemão. Explorar as relações entre infância e sertão na obra rosiana seria tema não de um capítulo - quem dirá de subcapítulo! -, mas de todo um outro percurso de pesquisa, quiçá ainda por se fazer. Por ora, gostaríamos de apontar aqui apenas algumas imagens que se tocam, traços que aproximam a ambos.

Grande Sertão: Veredas é, do início ao fim, pontuado por definições do sertão. Por "asisado e instruído" que seja, o doutor ouvinte de Riobaldo é urbano, e logo no início de seu relato o ex-jagunço fornece-lhe definição bastante sintética, mas não desprovida de densidade: "Lugar sertão se divulga: é onde os pastos carecem de fechos; onde um pode torar dez, quinze léguas, sem topar com casa de morador; e onde criminoso vive seu cristo-jesus, arredado do arrocho de autoridade" (2005, p. 24). Condensadas aí se encontram dimensões físicas e metafísicas.

Os pastos carecem de fechos: lugar da não demarcação, onde as fronteiras e limites de ordens várias - políticas, sociais, morais, religiosas, linguísticas, etc. - não se encontram de todo impostos ou bem definidos, tornando o sertão um campo do aberto, das múltiplas possibilidades, em que "tudo é perdido, tudo é achado" (p. 470). Nesse esfumaçamento radica-se também sua latente ambiguidade; o sertão é lugar por excelência da coincidência dos opostos, sobre o qual o regime racionalista da não contradição não tem domínio: onde criminoso vive seu Cristo-Jesus, arredado do arrocho de autoridade, portanto bem e mal, deus e o diabo, assassino e santo, fabulação e realidade, amor e ódio, guerra e paz, se misturam, vertem e revertem uns nos outros.

Assim também o existir infante, aquém dos cerceamentos sociais e racionais, é campo do aberto, onde a carência de "fechos", normas, padrões e estruturas revela-se 
potência enquanto campo de mais vastas possibilidades existenciais, imaginativas, linguísticas. A própria criança rosiana, viemos mostrando, figura a coincidência de opostos do infinito no mínimo, ou de ignorância e sabedoria, silêncio e verbo criador, princípio e fim, para citar alguns dos aspectos que exploramos. E, como o sertão rosiano $^{161}$, ela reverte ou mesmo faz coincidir as dimensões objetivas e subjetivas, seu mundo interno determina muitas vezes a realidade externa e esta pode imprimir-se de forma intensa na sua interioridade. Antonio Candido há muito apontara esse aspecto projetivo da subjetividade a plasmar o meio físico rosiano: "Começamos então a sentir que a flora e a topografia obedecem frequentemente a necessidades de composição; que o deserto é sobretudo projeção da alma, e as galas vegetais simbolizam traços afetivos." (1991, p. 297). Mesmo a resposta do velho solitário, "no sistema de quase-doido", que Riobaldo encontra já próximo do cumprimento de sua vingança o reafirma: "Sertão não é malino nem caridoso, mano oh mano!: - ... ele tira ou dá, ou agrada ou amarga, ao senhor, conforme o senhor mesmo." (p. 537).

A existência infantil em que a subjetividade impera ainda aquém de certos processos delimitantes que o confronto com a alteridade impõe reflete-se, como vimos, no próprio manejo que os pequenos têm da linguagem, desde sua maior liberdade em relação ao léxico e às normas gramaticais até o uso da palavra como força de criação e transformação, aspectos que vimos se relacionarem muito intimamente com a concepção metafísica que Rosa faz da língua em seus próprios processos criativos, e que encontra ressonância em mais essa definição do sertão dada pelo autor: "No sertão, o homem é o $e u$ que ainda não encontrou um $t u$; por isso ali os anjos ou o diabo ainda manuseiam a língua" (LORENZ, 1991, p. 86).

Sertão - solidão: onde um pode torar dez, quinze léguas sem topar com casa de morador. A solidão física dos vastos espaços inabitados, mas também metafísica, solidão originária e original onde o sujeito pode deparar-se consigo mesmo. Lemos ainda em Grande Sertão: Veredas: "Sertão é o sozinho" (p. 325) e "O senhor sabe o que o silêncio é? É a gente mesmo, demais" (p. 438). Observamos a dimensão de solidão e silêncio dos infantes que comungam dessa origem principalmente em Nhinhinha e no Moço muito branco. Mas o Grivo também será descrito como "menino das palavras sozinhas", e sozinha, sem interlocutor que entenda sua querência pela

\footnotetext{
161 “[...] o sertão é o terreno da eternidade, da solidão, onde Inneres und Ausseres sind nicht mehr zu trennen" ("O interior e o exterior já não podem ser separados", citado em alemão por Guimarães Rosa em entrevista a Gunter Lorenz, Op. Cit, p. 86)
} 
imagem luminosa do arrozal, Djá/Iaí parte em sua busca. A solidão do Menino em seu confronto com a morte do peru e da árvore, não sentida por nenhum dos adultos que o rodeiam, antes, até desejada e provocada por eles, é a mesma que Miguilim sente em sua dor empática pelos tatus caçados e assombro com o prazer que os adultos extraem da morte. Solidão daqueles que ainda comungam de um lugar originário em que tudo se irmana, a Lei da Participação ${ }^{162}$ impera, somos com o mundo e o mundo é conosco; a criança percebe que está sozinha nessa forma de sentir e existir, pois são raros os que a compreendem ${ }^{163}$, tirante aquele que está na origem de tudo, personificação da compaixão no sentido etimológico mais próprio de sofrer com: "[...] pobrezinho de Deus sozinho em seu ofício, carecido de nenhuma amizade” (2001, p. 72), pensa Miguilim quando os demais querem convencê-lo a não ter pena dos tatus.

Para além dos espelhamentos acima, a paisagem sertaneja que a literatura rosiana evoca talvez, por si só, conjure uma infância: a terra, sua poeira avermelhante, o céu de variadas cores, o sol que tudo alaga, a noite e sua sinfonia sob lua e estrelas, a voz das águas de riachinhos borbulhantes ou rios ferozes, os tantos elementos vegetais e animais, suas plantas, flores, bichos, cheiros e texturas, primitivos elementos como os artesanatos de barro e pedra, panelas e gamelas de ferro, trançados de cipós e folhas, carros de bois, fogueiras e cantigas... tudo isso é a infância do sertão, sua imanência que imprime uma vivência sensorial, arcaica, que amalgama seres, paisagem, linguagem, sentimento, ação e pensamento quase que na mesma latente existência.

O sertão é aquele que está, como os infantes, imerso em seu próprio corpo sensível, em um tempo de presença absoluta regido por lógica outra. É aquele que será de alguma forma ultrapassado pelos processos de modernização - como as crianças serão moldadas pela aculturação, fôrmas linguísticas, educacionais, políticas, sociais mas, como esse "existir infante", algo dele também resiste, permanece... Vimos essa dinâmica nos contos "As margens da alegria" e "Os cimos", e ela se encontra bastante evidente em "Sorôco, sua mãe, sua filha"; a modernização do trem de ferro corta o povoado sertanejo como imagem da interferência institucional a dar solução para a impossibilidade de Sorôco cuidar da mãe e filha, ambas presas da loucura, que serão

\footnotetext{
162 Trabalhamos este conceito do antropólogo Lévy-Bruhl no capítulo 1.

${ }^{163}$ Não só a criança, mas, como vimos em personagens que guardam o existir infantil, o Grivo adulto e seu patrão Cara-de-Bronze comunicam-se num entendimento da poesia do mundo que não encontra ressonância nos demais, da mesma forma que é sozinho que Tio Bola viverá o mistério do fim-princípio, atravessando a morte-nascimento em conjunção com o sentido último do Natal, o Cristo Menino que renova o mundo, enquanto os demais, que vão para a cidade cumpri-lo apenas como ritual exterior, provavelmente o julgariam "sem juízo perfeito" se soubessem o que de fato se passou.
} 
levada para Barbacena com as despesas todas pagas pelo Governo. Mas o "canto de desrazão", expressão que ultrapassa todos os ditames da lógica, pois não vigorava certo "nem no tom nem no se-dizer das palavras" (2001, p. 63), cuja comunicação se faz por um sentido sensível mais do que inteligível, permanecerá com Sorôco e se fará partilhado por toda a comunidade, numa emergência, em meio à modernização, das potências "desarrazoadas" que estão no cerne mesmo do sertão rosiano e do existir infante. O próprio Riobaldo, já lembramos anteriormente, sentencia: “[...] cidade acaba com o sertão. Acaba?" (2005, p. 183), e não parece descabido, a nós que vimos o "vir aquém" coincidir com o "vir a ser" na obra rosiana, glosar-lhe o mote: O mundo acaba com a infância. Acaba? 


\section{À guisa de conclusão - De Sorrisos e Enigmas}

Com estas páginas chegamos ao fim de nosso percurso... Convencionamos este limite-arremate a nos reconfortar com algo que assume caráter de coisa inteira e definitiva. Mas todos sabemos que concluir é sempre defeituoso... Uma das conquistas da literatura moderna foi o salto para o aberto, os finais abruptos ou que deixam uma meia dúzia de perplexidades em suspenso... assim como a vida: "No real da vida, as coisas acabam com menos formato, nem acabam. Melhor assim. Pelejar por exato, dá erro contra a gente. Não se queira." (ROSA, 2001, p. 101) Quiçá este dia chegue para os pesquisadores igualmente.

Os estudiosos de Guimarães Rosa, porém, tem em seu próprio objeto a prerrogativa do inconcluso. Seu mundo em lemniscata reiteradamente nos ensina que não há dentro nem fora, princípio ou fim... que encerrar equivale a voltar ao início e que, após mais de seiscentas páginas de romance, ainda restamos em "travessia"... Assim é: percorremos o tema da existência infantil em sua obra, como ele se apresenta em personagens as mais pequeninas, naquelas que já se confrontam com o mundo em seus dissabores e nos adultos cuja linguagem, escuta, forma poética de ser e estar guardam essa dimensão infante... Mas ele permanece aberto.

Aberto porque haveria certamente outras personagens a explorar - o menino Guirigó, que encarna a reversibilidade bem-mal, inocência-malícia, Deus-Diabo, decisiva e inquietante figura a acompanhar o bando de Riobaldo nos momentos de desenlace da vingança. Ou a "meninazinha" de "Fita Verde no Cabelo" que, como o Menino, terá seu momento de queda do paraíso no encontro com a morte. Joãozezim, do "Recado do Morro", único são ao lado do artista Laudelim a integrar a cadeia de transmissores do inusitado recado gritado pelo "morrão"; do que, possivelmente, tiraríamos ainda outras aproximações entre o infante e o artista no campo da desrazão.

Aberto, porque aberto é esse lugar "originário" e "original" com o qual a existência infantil constantemente dialoga, seja na sua linguagem, no olhar inaugural para o mundo, na relação com bichos e plantas, ou em sua forma de ser mesma que escapa aos contornos bem definidos da psique, da sociedade, da cultura. Lugar em que o início e o fim se tocam, mas, como vemos n'"O Espelho", lugar ao qual se chega por meio de duplo movimento, paradoxalmente coincidente, de regredir e progredir, e que conjuga na imagem infante carência e potência. 
Aberto, principalmente, porque é uma existência que participa da Graça e do Mistério, temas constantes na obra rosiana que emergiram de uma forma ou outra em praticamente todas as figurações de existência infante aqui vistas sem que fosse possível, nem desejável, devassá-los completamente... "Mistério" é palavra que herdamos do latim mysterium e, antes, do grego mystérion, em cuja raiz está o termo mýein, "fechar, estar fechado" (CUNHA, 2010, p. 430). Rosa chamou sua terra natal de "mistério geográfico""164; nela, o recôndito se faz experiência sensível e estruturante dos sujeitos que, "fechados" por mares de morros em cujas dobras jamais se sabe o que jaz escondido, acabam por abrir em si vastos espaços ao invisto. Já bastante se apontou a coexistência, mesmo coincidência, de mythos e logos como uma das linhas de força da obra deste autor, que pede-nos, em meio ao jogo hermenêutico de decifração, a celebração daquilo que deve permanecer no segredo e no silêncio, como nos lembra o Menino d"Os Cimos" aqui estudado, mas também o jagunço Riobaldo. ${ }^{165}$

Pensamos que o mesmo se dá com esta existência infante. Muitos foram os aspectos que dela emergiram: a dimensão diminuta como lugar do infinito, a carência como potência, o estado aberto, móvel para a existência e as relações que se reflete em mobilidade também linguística, deslocamento de significantes e significados, reversibilidades várias entre subjetividade e objetividade, imaginação e realidade, grotesco e sublime, imanência e transcendência, princípio e fim... vir aquém e vir a ser.

No entremeio destes elementos que percorremos ao longo do trabalho, persiste um traço comum que parece pulsar no cerne mesmo das categorias marcantes dessa existência, ressoando na relação dos pequeninos com a palavra, consigo mesmos e com o mundo: os infantes são, invariavelmente, portadores de um segredo. Relembremos algumas passagens, com grifos nossos: de Djá/Iaí, em "Tresaventura", o narrador diz que "... os segredos a guardavam", que ela "segredava-se, da caixeta de uma sabedoria..." (p. 174) quando invocava sua imagem do arrozal e, por fim, que ela adormece "dona em mãozinha de chave dourada..." (p. 176) ${ }^{166}$. Nhinhinha, a "Menina de lá", instada pelos adultos a realizar milagres, "sorria, só, segredando seu - "Deixa... Deixa...", e sobre ela os próprios adultos "Decidiram de guardar segredo" (p. 70). De

\footnotetext{
${ }^{164}$ Assim Rosa se refere a Cordisburgo no início de seu discurso de posse na Academia Brasileira de Letras.

165 "Mas o Menino pensava que devia acontecer mesmo assim - que ninguém soubesse" (ROSA, 2001, p.231). Falando sobre o mistério maior de sua existência, o pacto com o Diabo, Riobaldo diz: "A peta, eu querer saldar: que isso não é falável. As coisas assim a gente mesmo não pega nem abarca. Cabem é no brilho da noite. Aragem do sagrado. Absolutas estrelas!" (2001, p. 438)

${ }^{166}$ A chave é imagem de acesso a algo que está fechado, guardado, secreto.
} 
Brejeirinha, em "Partida do Audaz Navegante" nos é dito que "... ela vivia em álgebra. Mas não ia contar a ninguém. Brejeirinha é assim, não de siso débil; seus segredos são sem acabar." (p. 167). O Menino, em sua descoberta inicial da morte n'"As Margens da Alegria", "Guardou dentro da pedra." (p. 54) ${ }^{167}$ o que viu e sentiu diante da árvore derrubada, enquanto ao final d'"Os Cimos", tendo atravessado a dor e a finitude para resgatar uma dimensão de eternidade no instante, novamente dentro do avião para retornar a casa, ele "Sorria fechado: sorrisos e enigmas, seus" (p. 234). Secreto é também o caráter daquilo que o Grivo, fechado no quarto, partilha com Cara-de-bronze, o "quem das coisas" que, por mais que ele tente comunicar, permanece incompreensível aos demais vaqueiros.

A todos aqueles que não comungam dessa forma outra de ser e sentir dos infantes, o segredo não logra ser partilhado, da mesma forma que, imaginamos, a família de Tio Bola jamais saberá, de fato, o nascimento-morte, origem-fim, vivido naquela noite de natal. A arcaica dimensão da face infante, rostinho de menos-quemenino vislumbrado ao fim de todo o périplo percorrido pelo narrador nos meandros de seu "vir aquém" para vir a ser, é narrado não sem a consciência de, quiçá, ter como ouvinte um a quem essa face ainda não se revelou, sendo possível que, mesmo partilhada, a revelação permaneça secreta: "Será que o senhor nunca compreenderá?" (2001, p. 127). Sondando o "centro do segredo" (p. 123), é este mesmo narrador que profere a célebre frase rosiana "Quando nada acontece, há um milagre que não estamos vendo" (p. 119); existir infante é, até aonde nosso percurso nos mostrou, "estar vendo" o milagre, mesmo quando as agruras da existência se impõem, ou os paradigmas do mundo adulto os vêm confrontar. O seu é um sorriso de quem sabe algo... algo aquém e além dos imperativos culturais e sociais, dos padrões de linguagem e pensamento pautados pela lógica hegemônica, e que, longe de nos alienar, abre, no cerne mesmo da realidade, veredas outras pelas quais atravessarmos.

A nós, leitores, nos resta sorrir com eles.

\footnotetext{
${ }^{167}$ A frase nos remete à conhecida expressão "segredo de pedra".
} 


\section{Referências bibliográficas}

\section{Obras de João Guimarães Rosa}

ROSA, João Guimarães. Grande Sertão: Veredas. 19ª ed. Rio de Janeiro: Nova Fronteira, 2001.

João Guimarães Rosa: correspondência com seu tradutor alemão Curt

Mayer-Clason: (1958 - 1967) / edição, organização e notas Maria Apparecida Faria Marcondes Bussolotti; tradução Erlon José Paschoal. Rio de Janeiro: Nova Fronteira: Academia Brasileira de Letras; Belo Horizonte, MG: Ed. da UFMG, 2003.

. João Guimarães Rosa: correspondência com seu tradutor italiano Edoardo Bizzarri. $3^{\text {a }}$ ed. Rio de Janeiro: Nova Fronteira, 2003.

. Manuelzão e Miguilim. 11 a ed. Rio de Janeiro: Nova Fronteira, 2001.

. No Urubuquaquá, no Pinhém. $6^{\mathrm{a}}$ ed. Rio de Janeiro: Livraria José Olympio Editora, 1978.

. Noites do Sertão. $11^{\mathrm{a}}$ ed. Rio de Janeiro: Nova Fronteira, 2016.

. Ooó do vovô: correspondência de joão Guimarães Rosa com Vera e Beatriz

Helena Tess. São Paulo: Edusp; Belo Horizonte: Editora PUC/Minas; Imprensa Oficial do estado de São Paulo, 2003.

Primeiras Estórias. 15ª ed. Rio de Janeiro: Nova Fronteira, 2001.

. Sagarana. $21^{\text {a }}$ ed. Rio de Janeiro: José Olympio, 1978.

. Tutaméia: Terceiras Estórias. $3^{\mathrm{a}}$ ed. Rio de Janeiro: José Olympio, 1969.

\section{Obras de outros autores}

ADORNO, Theodor W. \& HORKHEIMER, Max. Dialética do esclarecimento: fragmentos filosóficos; tradução, Guido Antonio de Almeida. Rio de Janeiro: Jorge Zahar Editora, 1985.

ARAÚJO, Heloísa Vilhena de. A raíz da alma. São Paulo: Editora da Universidade de São Paulo, 1992.

ARIÉS, Phillipe. História social da criança e da família. Rio de Janeiro: LTC - Livros Técnicos e Científicos Editora, 1981. 
ARRIGUCCI JR., Davi. "O mundo misturado: romance e experiência em Guimarães Rosa". Novos Estudos CEBRAPE, n 40, novembro 1994, pp. 7-29.

BACHELARD, Gaston. A poética do devaneio. São Paulo: Martins Fontes, 1988.

BONDÍA, Jorge Larrosa. "Notas sobre a experiência e o saber da experiência". Revista Brasileira de Educação, Jan/Fev/Mar/Abr 2002, n. 19, pp. 20 - 28.

BOSI, Alfredo. Céu, Inferno. São Paulo: Duas Cidades, Ed. 34, 2003.

BRUHL, Lucien Lévy. As funções mentais nas sociedades inferiores. Trad. E.L. de Souza Campos. Niterói: Teodoro Editora, 2015.

CADERNOS de Literatura Brasileira: João Guimarães Rosa, São Paulo, n. 20-21, dez. 2006 (Editado por: Instituto Moreira Salles. Edição comemorativa de dez anos)

CAMACHO, Fernando. "Entrevista com João Guimarães Rosa". Revista Humboldt, Munique; Rio de Janeiro, 1978, vol. 18, nº 37, pp. 42 - 55.

CAMPBELL, Joseph. O herói de mil faces. trad. Adail Ubirajara Sobral. São Paulo: Pensamento, 2007.

CAMPOS, Haroldo. "Depoimentos sobre João Guimaraes Rosa e sua obra". Suplemento crítico da edição comemorativa A Boiada, Rio de Janeiro, Nova Fronteira, 2011.

CANDIDO, Antonio. "Literatura e subdesenvolvimento". In: A educação pela noite e outros ensaios. São Paulo: Ed Ática, 1989. . "O direito à literatura". In: Vários escritos. Rio de Janeiro: Ouro sobre azul, 2011.

. "O homem dos avessos". In: COUTINHO, Eduardo F. (org.). Guimarães Rosa, Rio de Janeiro, Civilização Brasileira, 1991 (Coleção Fortuna Crítica v.6). . "Sagarana". In: COUTINHO, Eduardo F. (org.). Guimarães Rosa, Rio de Janeiro, Civilização Brasileira, 1991 (Coleção Fortuna Crítica v.6).

CASSIRER, Ernst. "A palavra mágica". In: Linguagem e mito. 4a ed. São Paulo: Perspectiva, 2000, pp. 63-79.

CASTELlO, Luís e MARISCO, Claudia. Oculto nas palavras: Dicionário Etimológico de termos usuais na práxis docente. Belo Horizonte: Autêntica, 2007.

CHOMBART DE LAUWE, Marie-José. Um outro mundo: a infância [trad. Noemi Kon]. São Paulo: Perspectiva, 1991.

CHEVALIER \& GHEEBRANT Dicionário de Símbolos (mitos, sonhos, costumes, gestos, formas, figuras, cores, números); tradução Vera da Costa e Silva [et. al.] $22^{\mathrm{a}}$ ed. Rio de Janeiro: José Olympio, 2008. 
CORTÁZAR, Julio. "Para uma poética". In: Valise de cronópio. São Paulo: Perspectiva, 2013 (Coleção Debates).

COUTINHO, Eduardo F. (org.). Guimarães Rosa. Rio de Janeiro, Civilização Brasileira, 1991. (Coleção Fortuna Crítica v.6).

CUNHA, Antonio Geraldo da. Dicionário Etimológico da Língua Portuguesa. $4^{\mathrm{a}}$ edição revista pela nova ortografia. Rio de Janeiro: Lexicon, 2010.

DUHAMEL, Georges. Les plaisirs et les jeuxs, mémoires du Cuib et du Tiup. Paris: Mercure de France, 1923.

EAGLETON, Terry. Teoria da literatura: uma introdução. trad. Waltensir Dutra. $6^{\mathbf{a}}$ ed. São Paulo: Martins Fontes, 2006.

ELIADE, Mircea. Mythes, rêves et mystères. Paris, Gallimard, 1957.

FOUCALT, Michel. História da Loucura na Idade Clássica. São Paulo: Perspectiva, 1978.

. O pensamento do exterior. São Paulo: Editora Princípio, 1966.

FREUD, Sigmund. "Além do princípio do prazer" [1920] In: Além do princípio do prazer, psicologia de grupo e outros trabalhos. Rio de Janeiro: Imago, 1969. p. 17 - 85 (Obras psicológicas completas de Sigmund Freud, vol. XVIII)

. "Dois princípios do funcionamento mental" (1911) In: . "O caso Schreber, artigos sobre técnica e outros trabalhos". Rio de Janeiro: Imago, 1969. p. 277 - 286 (Obras psicológicas completas de Sigmund Freud, vol. XII)

. "Escritores criativos e devaneios" (1908 [1907]) In: "Gradiva" de Jansen e outros trabalhos. Rio de Janeiro: Imago, 1969. p. 149 - 158 (Obras psicológicas completas de Sigmund Freud, vol. IX) . "Lembranças encobridoras" (1899) In: . "Primeiras publicações Psicanalíticas". Rio de Janeiro: Imago, 1969. p. 333 - 354 (Obras psicológicas completas de Sigmund Freud, vol. III) . "Sobre a Transitoriedade" (1916 [15]). In: História do movimento psicanalítico, artigos sobre metapsicologia e outros trabalhos. Rio de Janeiro: Imago, 1969. p. 345 - 348 (Obras psicológicas completas de Sigmund Freud, vol. XIV). . Neuroses de transferência: uma síntese. Rio de Janeiro: Imago, 1987. FRYE, Northrop. Anatomia da crítica. Trad. P.E.S. Ramos. São Paulo: Cultrix, 1973. GUIMARÃES, Vicente. A infância de João Guimarães Rosa. São Paulo: Panda Books, 2006. 
HESÍODO. Teogonia: a origem dos deuses; estudo e tradução de Jaa Torrano. $6^{\mathrm{a}}$ ed. São Paulo: Iluminuras, 2006.

JESUS, Shirley Maria de. "Considerações sobre a questão do tempo em 'As margens da alegria' e 'Os Cimos'", Veredas de Rosa II, PUC Minas, CESPUC, 2003, pp 725 732 .

JUNG, C.G. \& KERÉNYI, K. Essays on a science of mythology: the myth of the divine child and the mysteries of eleusis. Englsh translation by R.F.C.Hull. Bollingen Series XXII, New York: Pantheon Books, 1949.

JUNG, C.G.; KERÉNYI, C. A Criança divina: uma introdução à essência da mitologia. Trdução de Vilmar Schneider. Petrópolis, RJ: Vozes, 2001. (Coleção Reflexões Junguianas

LEAL, Bernardina Maria de Sousa. Chegar à Infância. Niterói, EdUFF, 2011.

LEEMING, David; PAGE, Jack. Goddess: Myths of the Female Divine. Oxford University Press, NY, 1994.

LEITE, Dante Moreira. Psicologia e Literatura. São Paulo: ed Unesp, 2002.

LELOUP, Jean-Yves. Uma arte de amar para os nossos tempos: O Cântico dos Cânticos. (trad. Martha Gouveia da Cruz). Petrópolis, RJ: Editora Vozes, 2010.

LIEVEGOED, Bernardus Cornelius Johannes. Desvendando o crescimento - As fases evolutivas da infância e da adolescência. (trad. Rudolf Lanz). São Paulo: Antroposófica, 1994.

LISBOA, Henriqueta. "O motivo infantil em Primeiras Estórias". In: COUTINHO, Eduardo F. (org.) Guimarães Rosa, Rio de Janeiro, Civilização Brasileira, 1991 (Coleção Fortuna crítica, v.6).

LISPECTOR, Clarice. Os melhores contos de Clarice Lispector. Seleção Walnice Nogueira Galvão, 2a ed. São Paulo: Editora Global, 1998. . A descoberta do mundo. Rio de Janeiro: Rocco, 1999.

LORENZ, Günter. "Diálogo com Guimarães Rosa". In: COUTINHO, Eduardo F. (org.). Guimarães Rosa. Rio de Janeiro, Civilização Brasileira, 1991 (Coleção Fortuna Crítica v.6)

MARTINS, Nilce Sant'Anna. O léxico de Guimarães Rosa. São Paulo: Edusp, 2008

MENESES, Adélia Bezerra de. Cores de Rosa. Cotia, SP: Ateliê Editorial, 2010. Do poder da palavra: ensaios de literatura e psicanálise. São Paulo: Duas Cidades, 2004. 
."'Partida do Audaz Navegante', de Guimarães Rosa: ressonâncias odisseicas, em clave minimalista", Literatura e Sociedade, v. 20, n. 20, p. 55-66, 18 jun. 2015.

MEYER-CLASON, Curt. "Guimarães Rosa". Conferência pronunciada no Goethe Institut de Belo Horizonte, 24.10.1968. Suplemento Literário de Minas Gerais, Belo Horizonte, 23.11.1968.

MORAES, Anita Martins Rodrigues de. "Era, outra vez em quando, a alegria". Veredas de Rosa III. Org. Lélia Parreira Duarte... [et al.]. Belo Horizonte: PUC Minas, Cespuc, 2007.

NOGUEIRA, Erich Soares. "O corpo e a palavra: uma leitura de 'Campo geral' de João Guimarães Rosa", SCRIPTA, Belo Horizonte, v. 9, nº 17, p. 369-394, 2º semestre 2005. NUNES, Benedito. "O amor na obra de Guimarães Rosa". In: A Rosa o que é de Rosa: literatura e filosofia em Guimarães Rosa. (Org. Victor Sales Pinheiro) Rio de Janeiro: DIFEL, 2013.

. "A viagem do Grivo". In: A Rosa o que é de Rosa: literatura e filosofia em Guimarães Rosa. (Org. Victor Sales Pinheiro) Rio de Janeiro: DIFEL, 2013. . “A existência absurda". In: O dorso do tigre. São Paulo: Ed. 34, 2009. . O tempo na narrativa. São Paulo: Editora Ática, 2003.

PACHECO, Ana Paula. O lugar do mito: narrativa e processo social nas Primeiras estórias de Guimarães Rosa. São Paulo: Nankim, 2006.

PAES, José Paulo. "Para uma pedagogia da metáfora". In: Armazém Literário: ensaios. Organização e apresentação de Vilma Arêas. São Paulo: Companhia das Letras, 2008. PASTA, JR., José Antonio. "O romance de Rosa: temas do Grande Sertão e do Brasil", Revista Novos Estudos, no 55, Nov. 1999.

PAZ, Octavio. O Arco e a Lira. São Paulo: Cosac Naify, 2012. Signos em rotação. São Paulo: Perspectiva, 2015.

PELBART, Peter Pál. A nau do tempo-rei: sete ensaios sobre o tempo da loucura. Rio de Janeiro: Imago Editora, 1993.

PEREZ, Renard. "Guimarães Rosa". In: COUTINHO, Eduardo F. (org.). Guimarães Rosa. Rio de Janeiro, Civilização Brasileira, 1991 (Coleção Fortuna Crítica v.6) PERRONE-MOISÉS, Leyla. "Nenhures 2: Lá, nas campinas", SCRIPTA, Belo Horizonte, vol.2, n.3, 2ºm. 1998. . "Para trás da Serra do Mim", SCRIPTA, Belo Horizonte, v 5, n. 10, p. 210217, $1^{\circ}$ sem. 2002. 
PESSOA, Fernando. Poesia de Alberto Caeiro. São Paulo: Companhia das Letras, 2001.

PIAGET, Jean. O nascimento da inteligência na criança. Zahar Editores, 1970.

PIAGET, Jean \& INHELDER, Bärber. A psicologia da criança (trad. Octavio Mendes Cajado). $16^{\text {a }}$ ed. Rio de Janeiro: Bertrand Brasil, 1999.

PLATÃO. Diálogos; seleção de textos de José Américo Motta Pessanha; traduções e notas de José Cavalcanti de Souza, Jorge Paleikat e João Cruz Costa. $2^{a}$ ed. São Paulo: Abril Cultural, 1979.

PLATÃO. Diálogos; tradução de Jorge Paleikat. $3^{\text {a }}$ ed. Rio de Janeiro - Porto Alegre São Paulo: Editora Globo, 1954.

PLATÃO. Mênon; texto estabelecido e anotado por John Burnet; tradução de Maura Iglesias. Rio de Janeiro; Ed. PUC-Rio; Loyola, 2001.

PORTELLA, Oswaldo. "Vocabulário Etimológico básico do académico de letras" In: Letras, Curitiba (33), UFPR, 1984, pp. 103-119.

RESENDE, Vania Maria. "A trajetória do menino nas estórias de Guimarães Rosa". In: O menino na literatura brasileira. São Paulo: Perspectiva, 1988.

RÓNAI, Paulo. "Os vastos espaços". In: Primeiras Estórias - $15^{\mathrm{a}}$ ed. - Rio de Janeiro: Nova Fronteira, 2001. "Os Prefácios de Tutaméia", O Estado de São Paulo, 16 de março de 1968.

ROSA, Vilma Guimarães. Relembramentos: João Guimarães Rosa, meu pai. Rio de Janeiro: Nova Fronteira, 2014.

ROSENBAUM, Yudith. “Guimarães Rosa e o canto da desrazão”. Revista Ângulo 115, out./dez. 2008, p. 150-158.

ROSENFIELD, Kathrin. "Fingir a verdade". In: Outras Margens: estudos da obra de Guimarães Rosa, (org. Leila Parreira Duarte, Maria Theresa Abelha Alves), Belo Horizonte, Autêntica/PUC Minas, 2001.

SEGAL, Hanna. "Notas sobre la formación de símbolos". Revista de Psicoanálisis de la Asoc. Psic. de Madrid (2013), n. ${ }^{\circ}$ 69, pp. 53-72

SIMÕES, Irene Gilberto. Guimarães Rosa: As Paragens Mágicas. São Paulo: Perspectiva, s/d.

SPERBER, Suzi Frankl. Caos e Cosmos: leituras de Guimarães Rosa. São Paulo: Duas Cidades, 1976. . Guimarães Rosa: signo e sentimento. São Paulo: Ática, 1982. 
TORRANO, JAA. "Ouvir, Ver, Viver a canção". In: HESÍODO. Teogonia: a origem dos deuses, [estudo e tradução Jaa Torrano]. 6ª ed. São Paulo: Iluminuras, 2006.

TRÊS INICIADOS. O Caibalion: estudo da filosofia hermética do antigo Egito e da Grécia. [Trad. Rosabis Camaysar]. São Paulo: Editora Pensamento, 1997.

VERMOREL, Henry. "Sigmund Freud et Romain Rolland, correspondance 19231936", Histoire de la Psychanalyses, Paris: PUF, 1993.

VICO, Giambattista. A ciência nova; tradução prefácio e notas, Marco Lucchesi. Rio de Janeiro: Record, 1999.

WINNICOTT, D. O brincar e a realidade. Rio de Janeiro: Imago Editora LTDA, 1975. WISNIK, José Miguel. "O famigerado". SCRIPTA, Belo Horizonte, v. 5, n 10, pp. $177-$ $198,1^{\circ}$ semestre 2002. 